\author{
UNIVERSIDADE DE SÃO PAULO \\ FACULDADE DE FILOSOFIA, LETRAS E CIÊNCIAS HUMANAS \\ DEPARTAMENTO DE FILOSOFIA \\ PROGRAMA DE PÓS-GRADUAÇÃO EM FILOSOFIA
}

\title{
EZEQUIEL IPAR
}

\author{
A CORRENTE SUBTERRÂNEA DA ESCOLA DE \\ FRANKFURT. \\ TEORIA SOCIAL E TEORIA ESTÉTICA EM THEODOR \\ ADORNO
}

São Paulo 2009 


\section{EZEQUIEL IPAR}

\section{A CORRENTE SUBTERRÂNEA DA ESCOLA DE FRANKFURT. \\ TEORIA SOCIAL E TEORIA ESTÉTICA EM THEODOR ADORNO}

Tese apresentada ao programa de Pós-Graduação em Filosofia do Departamento de Filosofia da Faculdade de Filosofia, Letras e Ciências Humanas da Universidade de São Paulo, para obtenção do título de Doutor em Filosofia sob a orientação da Profa. Dra. Olgária Chain Féres Matos.

São Paulo

2009 
À minha avó e ao meu pai

In memoriam 


\section{Agradecimentos}

Agradeço à professora Olgária Matos, por sua valiosa colaboração, sua generosidade e pela inspiração de seus trabalhos, que fizeram possível a realização desta tese. Também agradeço aos professores Wolfgang Leo Maar e Ricardo Nascimento Fabbrini, por sua participação no exame de qualificação.

Agradeço especialmente aos meus amigos Enéias Forlin, Silvio Carneiro e Vítor Schincariol, por sua leitura atenta da tese original, seus valiosos comentários e as sugestões que enriqueceram o conteúdo deste texto. E faço extensiva minha gratidão a todos os amigos de São Paulo, em particular a Henrique Xavier, Marinê Pereira, Silvana Ramos, Mayra Pinto, Graciela Foglia, Cristiano Rezende, Alex Calheiros, Nelson Tomelin, Éricka Itokasu, Marie Pedroso e Juliana Gristelli. Agradeço muito especialmente a Mariana de Gainza, pela colaboração, compreensão e inteligência no momento da discussão das idéias.

Por último, agradeço à equipe da Secretaria do Departamento de Filosofia da FFLCH, pela constante disposição e ajuda indispensável. 


\section{RESUMO}

No presente trabalho tentamos reconstruir os principais lineamentos da teoria estética e da teoria da sociedade de Theodor Adorno. Com tal propósito, partimos de uma revisão critica da interpretação canônica efetuada tanto por Jürgen Habermas como por Axel Honneth do potencial explicativo contido em obras clássicas da primeira geração da Escola de Frankfurt. O objetivo central deste confronto procura demonstrar que o conceito de cultura de Adorno y Horkheimer tem um potencial explicativo e critico que nem Habermas, nem Honneth souberam destacar. Para reexaminar esse potencial teórico subterrâneo resulta imprescindível referir-se as duas grandes obras da maturidade de Adorno, a Teoria estética e a Dialética negativa. Realizamos-nos esse trabalho procurando explicitar um conceito de cultura alternativo ao de Habermas e Honneth, para tentar logo extrair conclusões referidas à lógica interna das ciências sociais.

Palavras-chave: Escola de Frankfurt - Teoria social - Teoria estética - Dialética negativa 


\begin{abstract}
The object of this thesis is to reconstruct the basic lines of Adorno's aesthetic and social theory. We discuss Jürgen Habermas' and Axel Honneth's canonic interpretation about the theoretic potential of the classic works of the first generation of the Frankfurt School. The central aim of this confrontation is to demonstrate that the concept of culture developed by Adorno and Horkheimer has a theoretic potential that had not been perceived by Habermas and Honneth. In order to reevaluate this potential it is necessary to discuss the last Adorno's works, which means, to discuss once again the Aesthetic Theory and the Negative Dialectics. We pretend to find, finally, a different concept of culture in order to use it in the critical reexamination of the internal logic of social sciences.
\end{abstract}

Key-words: Frankfurt School - Social Theory - Aesthetic Theory - Negative Dialectics 


\section{SUMÁRIO}

Introdução

A ordem do discurso moderno e o começo das Ciências Sociais

Primeira Parte: A Ideologia frankfurtiana

Capitulo 1: A idade da Razão. A superação pragmática das antinomias do racionalismo burguês

Capitulo 2: Em busca da política perdida. A filosofia política hegeliana na era do Estado Social

Segunda Parte: $O$ olhar de Apolo. A arte como momento

negativo da cultura

Capitulo 3: O duplo sentido da técnica. Adorno e a dialética

da modernidade cultural

Capitulo 4: O olhar de Apolo. A arte como momento negativo na constituição da modernidade cultural 
Siglas das obras de Adorno citadas:

$\begin{array}{ll}\text { (PF) } & \text { Philosophische Frühschriften } \\ \text { (DA) } & \text { Dialektik der Aufklärung } \\ \text { (MM) } & \text { Minima Moralia } \\ \text { (ND) } & \text { Negative Dialektik } \\ \text { (̈̈T) } & \text { Ästhetische Theorie } \\ \text { (SS I) } & \text { Soziologische Schriften I } \\ \text { (SS II) } & \text { Soziologische Schriften II } \\ \text { (KG I) } & \text { Kulturkritik und Gesellschaft } \\ \text { (KG II) } & \text { Kulturkritik und Gesellschaft }\end{array}$

Aclaração: a tradução do alemão de todas as referencias as obras de Adorno é nossa. Em todos os casos cotejamos nossa tradução com as versões disponíveis em português, espanhol e francês. 


\section{Introdução}

\section{A ordem do discurso moderno e o começo das Ciências Sociais}

A história da Teoria Crítica da "Escola de Frankfurt" está associada ao destino dessas raras tradições que se fraturam, contraem-se e dissipam-se no mesmo momento de sua gestação. Sem que isto implique - necessariamente - uma diminuição de seu valor, quando se trata de estudar a obra de algum de seus autores, essa estranha condição exige ser mais uma vez explicitada e analisada. Pode-se chegar, inclusive, à conclusão de que a peculiaridade desta tradição de pensamento reside no modo como continua vivendo além das (e contra as) tentativas de canonização acadêmica e cultural que pretendem transformála simplesmente em uma tradição cultural. A dialética do legado e a herança que existe entre a obra de Theodor Adorno e Jürgen Habermas permite mostrar, sem necessidade de antecipar uma valoração apressada de seu resultado, um caso muito concreto desta vitalidade e de seu alcance para os principais debates no campo da filosofia e das ciências sociais contemporâneas.

No final da década de 1960, a expressão "Escola de Frankfurt" ainda era empregada de modo vago, episódico e sem muita relevância. Para mencionar só um exemplo, naquela época, em suas lições na Universidade, Theodor Adorno (Adorno, 1993 e 2008) utilizava-a muito ocasionalmente para se referir à atividade teórica que desenvolvia o Instituto de Investigação Social de Frankfurt (no contexto situado de sua polêmica com o positivismo e a hermenêutica) e para enquadrar a relação com a teoria crítica da modernidade capitalista de Marx, que se podia encontrar na obra de autores tão diversos como o próprio Adorno, Max Horkheimer, Walter Benjamin, Herbert Marcuse, Leo Löwenthal ou Friedrich Pollock. Até esse momento, a "Escola de Frankfurt" não podia ser representada nem sob a unidade de uma doutrina teórica, nem segundo a uniformidade de um saber institucionalizado. Uma década mais tarde, porém, essa situação se transforma radicalmente quando, no que poderia parecer um paradoxo, Jürgen Habermas ${ }^{1}$ e Axel Honneth ${ }^{2}$ consagram a imagem do

\footnotetext{
${ }^{1}$ De nenhum modo seria legítimo afirmar que esta consagração da Escola de Frankfurt como uma doutrina teórica definida e um saber institucionalizado particular foi algo que levou a cabo exclusivamente Habermas (junto com Honneth). O que se pode afirmar é que é no contexto da fundamentação do paradigma da ação comunicativa que esta operação completa-se e projeta-se como uma evidência. Entre os múltiplos textos de Habermas que constroem e reproduzem esta interpretação os mais importantes são: "La crítica de la razón
} 
desenvolvimento contínuo de uma "Escola" de pensamento, no preciso momento em que propõem a necessidade de sua superação. Por meio da identificação de uma escola de filosofia social crítica que possuía, por direito próprio, esse nome, tal tradição de pensamento passa agora, mediante esta interpretação, a ter seus pais fundadores, um corpus de textos fundamentais, uma perspectiva filosófica reconhecível e uma história institucional no campo da filosofia e das ciências sociais. A estratégia básica desta reconstrução reconhecia, nas figuras de Horkheimer e Adorno, os forjadores da tradição da "Teoria Crítica Frakfurtiana"; na Dialética da Ilustração, o texto fundacional; numa filosofia da história em chave negativa (ou pessimista), a perspectiva filosófica central; e, nas investigações e publicações sociológicas que se dedicavam a estudar o incremento incessante das formas de dominação que se exercem sobre os homens, o traço essencial da continuidade institucional da Escola no campo da ciência.

Talvez sem procurá-lo, Habermas e Honneth repetiam, com esta leitura de seus antecessores, uma velha estratégia empregada no campo da história das ideias filosóficas por Hegel; estratégia que permite reconhecer o núcleo profundo de um pensamento, quer dizer, todas as suas determinações essenciais, quando este já se tornou parcial, abstrato e insatisfatório frente aos requisitos que a atualidade impõe a um pensar atento. Ao utilizar de novo este duplo fio da dialética, Habermas e Honneth modificaram o olhar que a Teoria Crítica dirigia a Hegel (e à história), deslocando-o das margens para o centro da sua filosofia, e transformando o questionamento de seus limites, que ainda pretendia Adorno, na adoção da estrutura formal e do aparelho procedimental de seu pensamento. Não resulta estranho, por outro lado, que este deslocamento em relação a Hegel se dê no marco de uma reconstrução da Razão que começa a depender, cada vez mais decididamente, de uma teoria

instrumental” (Habermas, 1987ạ: 465-508); “Max Horkheimer, la escuela de Frankfurt en Nueva York” (Habermas, 1984: 363-375) e "Horkheimer y Adorno, el entrelazamiento de Mito e llustración" (Habermas, 1989: 135-162). Outros textos de outros autores relevantes que merecem ser mencionados são: Albrecht Wellmer, "Communication and Emancipation: Reflections on the linguistic turn in: Critical Social Theory", in: On Critical Theory, New York, 1989; David Held, "Introduction to Critical Theory. Horkheimer to Habermas", Berkeley, 1980.

${ }^{2}$ Entre os textos mais significativos desta primera etapa do pensamento de Honneth, que operam articuladamente com a interpretação de Habermas, há que se destacar três: "From Adorno to Habermas: On the Transformation of Critical Social Theory" (Honneth, 1995: 92-120); “Critical Theory" (Honneth, 1995: 6191) e "The Incapacity for Social Analysis: Aporias of Critical Theory" (Honneht, 1997: 3-96). 
da evolução cultural. O que é importante ressaltar é que esta leitura hegeliana, que converte uma variada série de textos, posições críticas e autores, na "Escola de Frankfurt", é a que institui, ao mesmo tempo, sua "insuficiência metodológica" e sentencia a "impossibilidade de cobrir com esse legado os requisitos da teoria social crítica" (Grossner, 1971: 15).

No centro desta interpretação, os textos de Adorno e Horkheimer sofrem uma dupla transformação. Por um lado, deixam de ser fragmentos de uma reflexão que põe em evidência os extremos e as conexões impensadas do processo de racionalização da sociedade moderna e passam a ocupar uma posição central entre os discursos que fazem uma crítica frontal e total da Razão. Não importa que essa posição seja considerada como ambígua ou ambivalente (o que lhes teria permitido oscilar entre o projeto de "ilustrar a razão sobre si mesma" e o comportamento cínico frente ao pensamento teórico, típico de autores como Sade ou Nietzsche), o que importa é que os textos são situados em relação a essa posição, e é esse lugar que ocupam aquele que vai ser interpretado. Por outro lado, suas diversas teses passam a ter o estatuto de "intuições", "impressões", "observações", simples esquemas de problemas mais complexos, que dependem da estrutura interna de um "livro estranho", composto de um modo "também estranho", que consta "somente de um artigo" acompanhado, logo, de "dois excursus e três apêndices". De sua forma de exposição diz-se que é "bastante intrincada" e que "não permite reconhecer à primeira vista a estrutura da argumentação" (Habermas, 1989: 135-136).

Nesta dupla passagem, o aparelho hegeliano de leitura da história do pensamento funciona plenamente e em seus termos mais convencionais. É o mesmo movimento aquele que desloca os textos de Adorno e Horkheimer frente à pergunta que exige uma valoração a respeito da modernidade, e aquele que constata suas insuficiências, suas carências, seu caráter estranho em relação aos requisitos do saber teórico. Situá-los frente a essa pergunta é a condição de possibilidade de toda a interpretação, pois essa pergunta é a que distribui os interlocutores, hierarquiza os temas, mede o alcance e a intensidade da crítica que o texto pratica (crítica radical vs. crítica diferenciadora) e põe um limite à proliferação de sua forma (ao transformar, finalmente, a diversidade de seus enunciados em "argumentos").

A motivação explícita desta releitura é a defesa de uma crítica do processo de modernização que faça justiça, simultaneamente, a sua complexidade e a suas potencialidades ainda não realizadas. Trata-se de ler na história com mais equilíbrio, de um 
ponto de vista que permita sintetizar os ganhos do processo, para defender e projetar o interesse pela emancipação social que qualquer pensamento crítico requer como fundamento. Considerados a partir dessa perspectiva, os textos de Adorno e Horkheimer carecem desse ponto de equilíbrio e tornam inviável a possibilidade de reconstruir, de suas bases, o interesse dos homens por formas de vida emancipada e igualitária que se expressa (com todas suas limitações) no projeto da Ilustração. Daí que a interpretação que primeiro reconstrói logo fratura e, finalmente, anula a tradição da teoria crítica da "Escola de Frankfurt", seja a mesma que produz outro discurso, um segundo discurso que se autoarticula graças às ausências que (produz e) encontra no primeiro. Este outro discurso tenta reconstruir as partes e reagrupar as funções da Razão, superando as aporias e as limitações da Dialética da Ilustração. ${ }^{3}$

O peculiar deste discurso, que quer promover uma nova ordem na concepção da modernidade cultural, é sua necessidade de continuar e - ao mesmo tempo - separar-se daquilo que ainda se manifesta nos textos de seus antecessores. Nessa peculiaridade aparece, de um modo mais ou menos explícito, outro estrato de motivações. Analisando esta passagem com cuidado, pode-se constatar que a "ordem verdadeira" da modernidade não pode evitar organizar-se segundo uma ordem discursiva que relega suas autocertezas (associadas à substituição de um paradigma limitado por outro mais abrangente) a um segundo plano, e põe em primeiro lugar uma motivação diferente: o medo, em particular o medo da repetição na história (da tragédia europeia, da violência nua e sem limites etc.). No discurso que constroem Habermas e Honneth no final da década de 70 e começos dos 80,

\footnotetext{
3 “Por causa das simplificações que se praticam neste quadro, a Dialética da llustração não faz justiça ao conteúdo racional da modernidade cultural que se fixou nos ideais burgueses (ainda que também instrumentalizado neles). Refiro-me à específica dinâmica teórica que impele por vezes as ciências, e também a autorreflexão destas, apesar da geração de saber tecnicamente utilizável; da mesma forma, refiro-me aos fundamentos universalistas do direito que encontraram também personificação (por mais distorcida e imperfeita que seja) nas instituições dos Estados constitucionais modernos, nos modos de formação democrática da vontade coletiva, nos padrões individualistas de desenvolvimento da identidade pessoal; refiro-me, por fim, à produtividade e à força explosiva das experiências estéticas básicas que no comércio e no trato consigo mesma produz uma subjetividade descentrada, emancipada dos imperativos da atividade racional em conformidade com as finalidades e as convenções da percepção cotidiana experiências que se tornam patentes nas obras de arte de vanguarda que advertem quanto à linguagem nos discursos próprios da crítica de arte e que alcançam também um certo efeito iluminador -ou pelo menos instrutivo a efeitos de contraste- nos registros valorativos inovadoramente enriquecidos da autorrealização individual e grupal" (Habermas, 1989: 142-143; itálicos no original).
} 
pode-se perceber este lugar que adquire o medo na justificação da necessidade de sair, de superar a forma de teoria social crítica que se condensou na Dialética da Ilustração (e na atribuição à filosofia e às ciências sociais o papel da fundamentação das pretensões racionais da modernidade). Sem esta função central do medo à repetição, resulta muito difícil compreender em seu conjunto a interpretação que pretende deixar atrás os textos de Adorno e Horkheimer. Usando uma terminologia que popularizou a psicanálise lacaniana, é possível afirmar que, lá onde o sujeito do enunciado que consegue articular um discurso sistemático sobre a modernidade é a Razão crítica e diferenciadora, vislumbra-se um sujeito da enunciação que está integralmente construído pelo medo, fazendo desse temor a causa profunda da necessidade de "mudança de paradigma". Isto se torna evidente no tema que obceca este discurso: a eliminação da diferença - que leva a cabo a crítica radical - "entre aquilo que reclama validez e aquilo que é útil para a autoconservação", eliminação que termina "derrubando as barreiras entre validez e poder, anulando assim aquela distinção categorial à qual a compreensão moderna do mundo acreditava dever uma superação definitiva do mito" (Habermas, 1989: 149). ${ }^{4}$ Por último, a necessidade de excluir do horizonte da teoria crítica da sociedade toda investigação ou pensamento filosófico que não descubra e aceite a distinção entre validez e poder aparece, deste modo, como o autêntico objeto do discurso que centra novamente a teoria crítica em torno da pergunta que exige uma valoração da modernidade.

O alcance polêmico deste discurso adquiriu um rol predominante na discussão filosófica contemporânea, determinando, a partir da maneira como se efetua a fundamentação da distinção entre validez e poder, entre a ação de "seguir uma norma" e o fato de "conseguir obediência", o lugar das diferentes posições filosóficas do mundo "pósmetafísico". Esse mundo fica organizado segundo quatro orientações básicas: a) aquela que realiza uma destruição radical da distinção entre validez e poder, encarnada nas releituras de Nietzsche e Heidegger do pós-estruturalismo (Foucault-Deleuze-Derrida); b) aquela que promove uma dissolução débil dessa distinção, seguindo os postulados antimetafísicos do

\footnotetext{
${ }^{4}$ Uma das fundamentações mais relevantes da importância desta distinção entre validez e poder encontrase em: "Accesos a la problemática de la racionalidad", Habermas (1987a). O mesmo tratamento aparece em: Honneth, (1997): 41, 54-55. Recentemente Habermas ofereceu uma versão sistemática deste problema orientada à filosofia do direito e à teoria da democracia. Ver: Facticidad y Validez, ed. Trotta, Madrid, 2008.
} 
pragmatismo (Rorty); c) aquela que ensaia uma fundamentação débil desta, apoiada em uma teoria da ação comunicativa (Habermas); e d) aquela que procura uma fundamentação forte (ou última), ao atribuir à distinção entre validez e poder o lugar de princípio intransponível que sustenta todo pensamento (racional) crítico (Apel). Sobre o fundo desta organização das orientações básicas do pensamento, os principais textos de Adorno e Horkheimer são frequentemente apresentados como vacilantes e contraditórios, inclinados a transitar por extremos que logo não podem sintetizar em uma posição coerente. Neste sentido, fica automaticamente diminuído seu valor frente a cada uma dessas quatro posições, para além do juízo que se tenha sobre elas. É uma constante da interpretação de Habermas e Honneth a este respeito, encontrar em seus antecessores tanto uma propensão à destruição total da distinção entre validez e poder, quanto uma tentativa de alcançar um conceito enfático de racionalidade crítica que dependa de uma fundamentação forte, isto é, clara e definitiva, da distinção entre poder e validez (entre violência e vida justa). Ao distribuí-los desta maneira, negativamente, entre Foucault e Apel, ao mostrar sua vacilação inconsequente entre as posições extremas da destruição total da distinção e sua fundamentação absoluta, o que se pretende afirmar é, em definitivo, que a dialética negativa não é uma forma autônoma e singular de exercer o pensamento filosófico, e sim uma forma derivada e "parasitária" que, portanto, tem menos valor no mundo "pós-metafísico" que as quatro orientações básicas que o constituem.

Mas transformar a distinção entre validez e poder no centro da problemática filosófica não só serve, em termos gerais, para pôr uma certa ordem na modernidade cultural, mas também produz múltiplos efeitos específicos na relação que existe (ou pode existir) entre filosofia e ciências sociais, que é a questão que agora gostaríamos de começar a introduzir. Se posicionar-se frente a essa distinção (a favor ou contra) é um requisito para fazer parte da modernidade cultural filosófica, o reconhecimento positivo de sua necessidade transforma-se em uma conditio sine qua non das ciências sociais. Neste caso, o discurso que põe ordem na modernidade cultural, exigindo somente um fundamento fraco da racionalidade (filosófica e científica), faz dessa exigência um fundamento forte da "lógica das ciências sociais". Consideremos dois exemplos extremos: o filósofo e o físico na modernidade. Para o primeiro, como assinalamos, o não-reconhecimento da distinção entre validez e poder pode transformar-se na afirmação de outro princípio (a vida, o próprio 
poder, etc.), ou seja, a possibilidade de fundamentar um pensamento pós-metafísico desvinculado das ataduras da racionalidade. Dado que é $n a$ filosofia que essa distinção deve fazer-se efetiva, nela podem coexistir posições que a afirmam e que a negam. De modo diferente, algo semelhante acontece, entretanto, no campo das ciências naturais. Um físico que desejasse explicar a origem do universo seguindo uma teoria alternativa a do "Big Bang" pode desconhecer, é claro, a distinção entre faticidade e validez, sem que por isso seus enunciados tenham que ser desqualificados do campo da física (enquanto sejam satisfeitas condições de coerência lógico-matemática e adequação a todas as evidências empíricas e experimentos controlados já registrados na própria disciplina). Ao desconhecer (ou negar-se a aceitar) tal distinção, desconhece avanços importantes na filosofia da ciência moderna nos que se enquadra necessariamente sua atividade, mas que não a produzem nem a determinam internamente. Desconhece, por exemplo, a distinção entre o contexto de elaboração e o contexto de justificação do pensamento científico; mas, com isso, transforma-se somente num físico anacrônico, antipático ou presunçoso (que pensa que não precisa da interação e do auxílio de outros especialistas para estar certo sobre o conteúdo de verdade de sua teoria), sem ficar por isso excluído do campo da física. Devido ao fato de que a distinção entre faticidade e validez não determina em termos absolutos a produção de teorias físicas, estas podem ser geradas, desenvolvidas (e logo justificadas) sem a necessidade dessa distinção. $\mathrm{O}$ caso das ciências sociais é completamente diferente. De acordo como foi estabelecido o plano da experiência por este discurso que põe ordem na modernidade cultural, as ciências sociais não podem existir sem o reconhecimento da distinção entre faticidade e validez. Já que esta distinção as determina interna e absolutamente, toda investigação ou pensamento que se desloque do horizonte aberto por essa distinção ficará, automaticamente, excluído do campo das ciências sociais.

Habermas e Honneth justificam, de forma diferente e complementar, a necessidade da distinção entre validez e poder e, com isso, a exclusão da teoria social de todo enunciado que não seja compatível com ela. Nessa direção, fazem confluir os diferentes aspectos do pensamento social crítico, tentando dar forma à ideia de uma teoria crítica da sociedade. Para eles, o reconhecimento desta distinção não só assinala o começo lógico das ciências sociais, mas também deve ser entendido como o resultado histórico da totalidade das críticas que se efetuaram aos momentos ideológicos das principais vertentes do pensamento 
social moderno. Esta justificação vai servir-lhes para desvincular, em três etapas sucessivas, certos textos, como a Dialética da Ilustração ou a Dialética Negativa, dos problemas fundamentais das ciências sociais. Em primeiro lugar, excluem a crítica radical das pretensões da racionalidade moderna (feita pelo pós-estruturalismo e, em menor medida, pelo pragmatismo "irônico") do horizonte de qualquer fundamentação crítica das ciências sociais, ao considerar que esse tipo de crítica da sociedade moderna é completamente incapaz de relevar e analisar o potencial social de emancipação que ela contém. Essa incapacidade deve-se a, no pós-estruturalismo, todas as questões referidas à validez e à interação comunicativa entre os homens ficarem reduzidas a questões de relações de poder e ação estratégica. Por isso, o pós-estruturalismo pode fazer parte do "discurso filosófico da modernidade", mas não pode ingressar legitimamente no interior da "lógica das ciências sociais modernas". Seu olhar da sociedade é o olhar externo do filósofo ou do físico que se interessa pelo social, mas não é o olhar interno do sociólogo que reflete criticamente sobre sua própria atividade. Em segundo lugar, estabelecem a fundamentação (débil ou forte) da distinção entre faticidade e validez como o começo absoluto das ciências sociais, já que, sem esta distinção, vale dizer, sem a separação entre a natureza das leis que regem o mundo físico e a natureza das pretensões simbólicas contidas nas normas que regulam a interação dos homens, o próprio objeto destas ciências desaparece. Como só as distintas versões da teoria da ação comunicativa satisfazem esta condição em um mundo "pós-metafísico", são elas as encarregadas de fundamentar criticamente a lógica das ciências sociais. Finalmente, afirma-se que, ao ter ficado a obra de Adorno e Horkheimer aprisionada entre estes dois extremos do discurso filosófico da modernidade, seu destino no campo das ciências sociais será - para dizê-lo hegelianamente - o de um falso pressuposto ou um começo superado. $\mathrm{O}$ resultado desta operação é a exclusão da estratégia da dialética negativa das indagações sobre lógica ou epistemologia crítica das ciências sociais, ficando sob um cone de sombra o problema da mediação entre filosofia e ciências sociais que indagaram, ao longo de toda sua obra, Adorno e Horkheimer.

Para ligar de novo, como é o propósito deste trabalho, os principais textos da "primeira geração da Escola de Frankfurt" (em nosso caso, trataremos quase exclusivamente da obra de Adorno) com os problemas da fundamentação crítica das ciências sociais, é imprescindível atravessar este discurso frankfurtiano que decidiu 
(seguindo diversas motivações) fazer confluir os esforços do pensamento crítico com uma reconstrução autêntica da ordem da modernidade. Em tal sentido, devemos reconstruir e analisar detalhadamente - pois até aqui só riscamos grandes linhas - a interpretação habermasiana do pensamento filosófico de Adorno e a interpretação de Honneth do pensamento sociológico de Horkheimer e Adorno. Essas duas interpretações são as que fraturam e dissipam um tipo de teoria social crítica que lhes pertence e que ainda pode ser projetada sobre o mundo contemporâneo. Habermas realiza isto quando atribui à distinção entre esfera racional de validez intersubjetiva e esfera racional de ação instrumental a dupla condição de objeto e requisito epistêmico das ciências sociais. Honneth, por sua vez, desativa a atualidade de Adorno e Horkheimer ao atribuir à esfera de constituição da validez das normas a condição de campo excludente onde se dirigem e onde se resolvem o conjunto dos conflitos sociais, que são para ele a autêntica substância da dinâmica social e o objeto ao que deve acessar a representação das ciências sociais. A consequência lógica de ambas interpretações consiste no fato de que, para Habermas, o que já não se pode fazer é a continuar os esforços da Dialética da Ilustração ou da Dialética Negativa no sentido de uma teoria crítica da sociedade (cap. 1), enquanto o diagnóstico de Honneth consiste em destacar o motivo pelo qual a via desses textos está cancelada para uma autêntica teoria social crítica (cap. 2).

Para discutir os principais tópicos da análise de Habermas e Honneth procuraremos, na segunda parte deste trabalho, mostrar de que forma(s) o conceito de cultura que Adorno desenvolveu na sua obra crítica e na sua teoria estética pode oferecer uma concepção mais adequada dos dilemas sociais que se exprimem na dimensão cultural de capitalismo tardio (cap. 3 e 4). Finalmente, procuraremos tentaremos oferecer uma reformulação da discussão acerca da lógica das ciências sociais a partir das lições da teoria estética e da dialética negativa (conclusão). 


\section{Primeira Parte}

A Ideologia frankfurtiana 


\section{Capítulo 1: A idade da Razão \\ A superação pragmática das antinomias do racionalismo burguês}

No do tipo de relação entre filosofia e sociedade que promoveu historicamente a teoria crítica da sociedade, Georg Lukács deve ser considerado, sem dúvidas, como o grande precursor dessa tradição. Em História e Consciência de Classe, Lukács realiza uma das primeiras e mais geniais contribuições ao método de interpretação e crítica filosófica que logo fará parte do trabalho de Horkheimer, Benjamin, Kracauer e Adorno. A particularidade deste método consiste em permitir decifrar, nos problemas filosóficos de uma época, os principais problemas sociais (políticos e culturais) que a constituem e, num sentido oposto, mas complementar, encontrar nesses problemas sociais (ex.: a dinâmica histórica dos conflitos de classe) questões filosóficas profundamente arraigadas, que constituem seu sentido interno. ${ }^{5}$ É evidente que, procedendo desta maneira, Lukács estava apropriando-se de um legado importante da teoria (e da escritura) de Marx, especialmente aquele que consegue ler, no mundo "trivial e evidente das mercadorias", a persistência de "uma coisa diabolicamente complexa (vertracktes Ding), cheia de sutilezas metafísicas e ressaibos teológicos". 6

Para o Marx maduro, resulta muito claro que a sobrevivência da metafísica (e da teologia), no século XIX, não se deve ao crédito que desperta sua reconstrução apriorística da totalidade do mundo, e sim à forma das relações sociais, contida na estrutura da mercadoria. É essa forma social que transforma os objetos em "coisas fisicamente metafísicas" (sinnlich übersinnliches Ding) e converte a oscilação de seu valor no mercado em um autêntico "hieróglifo social" (gesellschaftliche Hieroglyphe) ${ }^{7}$, que deforma a representação (filosófica) da realidade, gerando a crença fetichista que atribui aos produtos do trabalho do homem a condição de objetos originários, independentes e dotados de uma vida própria que condiciona e regula a vida dos homens. Entretanto, Marx, nesta famosa

\footnotetext{
${ }^{5}$ Ver, em particular, "La cosificación y la conciencia del proletariado", in: Lukács, G., Historia y conciencia de clase II, ed. Grijalbo, Barcelona.

${ }^{6}$ Marx, K., Das Kapital, in: Marx und Engels Werke, B. 23, ed. Dietz, Berlin, p. 85.

${ }^{7}$ Ibid., p. 86 e 88 respectivamente.
} 
passagem acerca do fetichismo da mercadoria, não se limita a dar os primeiros passos na explicação de um problema filosófico (a persistência extemporânea da metafísica e da teologia em um mundo racionalmente "desencantado") remetendo-o a uma problemática social (a separação real que existe entre os produtores sob a forma do intercâmbio mercantil), mas parece reconhecer nessa problemática social, ao mesmo tempo, a incisão e a eficácia de um problema filosófico. De fato, é só a partir da reutilização da crítica da metafísica que se transformam em um autêntico problema teórico relações práticas tão "evidentes e triviais" como a abstração das múltiplas qualidades sensíveis das coisas trocadas no mercado, a equivalência de todas suas particularidades frente ao geral, a quantificação numérica de todos os modos de existência, a identidade do dinheiro que substancializa em si as relações que a constituem, a ilusão de independência dos sujeitos do processo de troca, a fantasia da liberdade incondicionada das suas relações e o pressuposto de um equilíbrio harmônico de todos os seus intercâmbios. Estes processos sociais, que passam despercebidos não só na experiência ordinária dos participantes, mas também na economia política e na filosofia, só aparecem como problemas sociais à luz de uma perspectiva filosófica que acha necessário manter a crítica da metafísica para além do espaço reservado e obscuro no qual os homens pensam e deliberam, levando-a também para a instância aberta e translúcida onde os homens produzem e interagem.

O método de interpretação e crítica filosófica de Lukács leva a sério este legado, atualizando-o, aprofundando-o e desenvolvendo-o. Seu tema central é a filosofia moderna ${ }^{8}$, e seu modo de análise, análogo neste aspecto aos primeiros passos da psicanálise, parte tanto do que nela "não é um problema, quanto daquilo que, sim, o é, e do modo como o é"9. A estratégia da análise consiste em individualizar as pretensões fundamentais da filosofia moderna (o conhecimento da conexão causal de todos os fenômenos, a exigência de aplicação do método matemático e a organização sistemática de todos os conhecimentos acumulados) para confrontá-las com seus próprios impasses, com suas dificuldades, com o

\footnotetext{
${ }^{8}$ A crítica de Lukács compreende um uso estrito do termo "filosofia moderna" e um uso mais amplo e metafórico. Por isso, pode abranger tanto o "racionalismo tipicamente moderno", quanto o "pensamento moderno" em geral. Em todos os casos a universalização do modo de produção capitalista é uma condição histórica indispensável para o uso adequado dessa categoria. Cfr., Lukács, G., op. cit., p. 41-44.

${ }^{9}$ Lukács, G., op. cit., p. 42.
} 
que não pode evitar pensar, apesar de não poder subsumi-lo satisfatoriamente dentro dessas pretensões (o melhor exemplo disto é sua famosa análise da "coisa em si" kantiana).

Para o Lukács de História e Consciência de Classe, os problemas da razão já não podiam ser isolados do contexto vital no qual esta se desenvolvia, devendo ser, portanto, entendidos como expressões das dificuldades objetivas do desenvolvimento do ser social. ${ }^{10}$ Por meio desta interpretação, Lukács colocou a razão no lugar de objeto privilegiado da teoria crítica da sociedade ${ }^{11}$, permitindo, deste modo, que todos os impasses do processo de sua autofundamentação na modernidade pudessem ser lidos como limites objetivos e potencialidades bloqueadas da práxis coletiva. A tarefa da teoria crítica consistiria em associar ambas as séries de problemas (os da práxis coletiva e os do processo de autofundamentação da razão, que aparecem totalmente dissociados na experiência ordinária da teoria filosófica e da vida prática) em uma determinada conjuntura histórica, tentando forçar, com essa associação, a produção de um tipo de autoconhecimento que seja capaz de

\footnotetext{
${ }^{10}$ Ao se referir às dificuldades para o pensamento moderno que aparece na passagem sobre as antinomias da Crítica da Razão Pura, Lukács afirma: "Escassamente trata-se aqui, como em todo ponto da filosofia clássica [do idealismo alemão], de problemas puramente intelectuais, de oposições puras entre especialistas" e sugere a título de explicação: "Em primeiro lugar, e em consequência do desenvolvimento da sociedade burguesa, todos os problemas do ser social perdem sua trascendência a respeito do homem, aparecem já como produtos da atividade humana, diferentemente do que ocorria na concepção medieval da sociedade e na concepção ainda vigente em princípios da idade moderna (por exemplo, com Lutero). Em segundo lugar, que este homem artificialmente ilhado pelo capitalismo tem que ser o burguês individual ilhado, e que, para tanto, a consciência como consequência da qual aparecem a atividade e o conhecimento tem que ser una consciência individual ilhada e robinsoniana. Porém precisamente por isso tem-se, em terceiro lugar, suprimido o caráter ativo da ação social. O que à primeira vista apresenta-se como eco da epistemologia sensista dos materialistas franceses - o fato de que seu cérebro não é mais do que uma cera adequada para receber todas as impressões que Ihe queiram aplicar, e, por outro lado, que como atividade não pode entender mais que seu fazer consciente - resulta ser, considerado mais de perto, simples consequência da posição do homem burguês no processo capitalista de produção. Já várias vezes indicamos qual é a base desta situação: o homem da sociedade capitalista enfrenta-se com a realidade que ele mesmo (na condição de classe) "faz» como com uma natureza que lhe fosse essencialmente alheia, encontra-se submetido sem resistência a suas "leis» e sua atividade não pode consistir em mais que aproveitar o funcionamento necessário e cego de algumas leis em seu própio interesse egoísta." Lukács, G., op. cit., p. 6970.

${ }^{11}$ Em sua Teoria da Ação Comunicativa Habermas vai, a partir de un ponto de vista muito semelhante, seguindo o de Weber, que é por outro lado no qual também se apoia direta ou indiretamente Lukács. Ver "EI concepto de racionalidad en sociología", em: Habermas (1987a): p. 15-23.
} 
"realizar uma alteração estrutural objetiva do objeto de seu conhecimento". ${ }^{12}$ O sentido "terapêutico" deste particular tipo de interpretação e análise filosófica está dado pela tentativa de "restabelecer o homem aniquilado pela coisificação" e de "superar a dualidade contemplativa de sujeito e objeto". ${ }^{13}$ Ao fazer possível o esclarecimento das barreiras do sujeito (do conhecimento, da moral, da política, da arte) como limitações históricas contidas na forma de suas relações sociais, torna possível que o sujeito cosificado por essas relações (que se experimenta a si mesmo, imediatamente, como objeto do mundo social) possa atualizar uma capacidade de ação transformadora, que até esse momento só existia na condição de pressuposto de sua realidade. A atualização dessa capacidade de ação transformadora, que é ao mesmo tempo resultado e pressuposto da teoria crítica, produz necessariamente, como seu efeito prático, uma ampliação das possibilidades de uma constituição comum do mundo, que era o que estava bloqueado, mas também insinuado nas pretensões da racionalidade que foram submetidas à crítica. ${ }^{14}$

A atribuição deste tipo de mediação entre filosofia e pensamento social à teoria crítica da sociedade é inquestionável. Dela depende que não se trate de uma teoria que possa esgotar-se na descrição dos momentos isolados do processo social ou na explicação das grandes leis que regulam sua reprodução. Para Habermas, é precisamente este tipo de análise e crítica "concientizadora" (Bewußtmachende) ${ }^{15}$ dos impasses da racionalidade moderna aquele que serve como modelo dos primeiros lineamentos que Horkheimer deu ao

\footnotetext{
${ }^{12}$ Lukács, G., op. cit., p. 111.

${ }^{13}$ Lukács, G., op.cit., p. 87.

${ }^{14}$ Não é demais mencionar que o movimento ao qual nos estamos referindo é muito mais complexo do que aqui nos interessa ressaltar. A consciência de classe do proletariado, posto que dela depende a teoria crítica da sociedade no caso de Lukács, não agrega, artificialmente e de fora, à história uma consciência mais ampla ou esclarecida a respeito do sentido potencial de seu desenvolvimento, mas "descobre no próprio processo histórico" esse potencial. Dessa forma, posto que este descobrimento "não é a consciência de um objeto separado", mas faz parte da "autoconsciência do objeto, o ato da tomada de consciência transforma a forma objetiva de seu objeto", e com isto, literalmente, pressupõe que logo irá "descobrir", isto é, que os limites do mundo coisificado não são os limites da práxis possível. Para um desenvolvimento amplo do peculiar uso lukacsiano, por outro lado evidente, da dialética da "posição e do pressuposto" hegelianos ver: Lukács, G., op. cit., p. 115-122.

${ }^{15}$ Ver Habermas, J., "Walter Benjamin. Bewußtmachende oder rettende Kritik", in: Philosophisch-politische Profile, ed. Suhrkamp, Frankfurt am Main, 1991.
} 
projeto de uma teoria interdisciplinária da sociedade. Mas é também Habermas (junto com Honneth) quem se encarrega de remarcar que esse modelo foi definitivamente interrompido e abandonado com a publicação da Dialética da Ilustração. E isso porque, nessa obra, Adorno e Horkheimer teriam se desvinculado drasticamente do pressuposto (a práxis précientífica de sujeitos que lutam por formas de vida racionais), obscurecendo definitivamente o método (a crítica imanente das pretensões da Razão) indispensável para a teoria crítica da sociedade. Por sua vez, estas duas carências, que se tornariam manifestas na Dialética da Ilustração, seriam as que ocasionaram uma perda de rumo, um "extravio" que os conduziu a formular conexões entre problemas filosóficos e problemas sociais que não podem encontrar uma justificação racional (a "modernidade" de Ulisses, o primitivismo da filosofia moral de Kant etc.), pois não fazem parte de uma mesma "época" histórica e não surgem do processo de autoesclarecimento de nenhum sujeito (ou instância intersubjetiva) reconhecível no mundo social.

A ruptura que Habermas popularizou, a partir da década de 80, em relação a Adorno e Horkheimer, carrega com as marcas indeléveis desta polêmica. Por isso, é importante perceber o modo específico pelo qual Habermas quebra a linha de continuidade no projeto de fundação de uma teoria crítica da sociedade. Nessas marcas não só aparecem as discrepâncias teóricas, mas também pode ler-se nelas, sintomaticamente, o conteúdo revulsivo e perigoso que a mudança do "paradigma da produção" para o "paradigma da ação comunicativa" teve que excluir para poder articular-se afirmativamente com seu próprio tempo.

A crítica da ambiguidade teórica da Dialética da Ilustração consta de três passos: em primeiro lugar, Habermas critica seu diagnóstico do capitalismo tardio, que se organiza sob o conceito de mundo administrado (a); em segundo lugar, critica as implicâncias de sua teoria das patologias sociais inerentes ao processo de racionalização, assinalando que seu alcance desmedido acaba tornando impossível a análise das potencialidades emancipatórias imanentes à própria sociedade, fazendo que a crítica dos momentos ideológicos da Razão não possa produzir uma efetiva separação entre ambos (b); finalmente, extrai a conclusão de que a partir da relação negativa do pensamento de Adorno e Horkheimer com respeito às pretensões da racionalidade, sua perspectiva torna-se incapaz de se inserir criticamente nas discussões referidas aos fundamentos teóricos das ciências sociais (c). 
a) $\mathrm{O}$ conceito de mundo administrado.

A primeira razão que esgrime Habermas a favor de uma mudança de paradigma na teoria crítica da sociedade depende da análise das imprecisões, os enganos e, finalmente, a falsidade de conjunto do diagnóstico que elaboraram Adorno e Horkheimer a respeito do capitalismo tardio ou - como o denominara o influente Pollock na década de 1940 capitalismo pós-liberal. O diagnóstico sombrio que Habermas encontra em seus predecessores descansa na redução do longo processo de racionalização social iniciado pela modernidade europeia no século XVIII a suas consequências "menos esperadas": a concentração monopólica da economia, o totalitarismo político implementado pelo fascismo e a organização de um sistema cultural-empresarial que destrói, em todas as suas produções, qualquer pretensão de autonomia. Este diagnóstico retomava unilateralmente segundo a interpretação habermasiana - os aspectos negativos que a teoria da racionalização weberiana já continha, algo assim como o momento kafkiano ${ }^{16}$ das teses que destacam uma progressiva perda de liberdade e sentido nas sociedades que passam a ser organizadas, massivamente, por meio de formas de ação racional (com respeito a fins). A partir desta redução teórica, aquilo que Adorno e Horkheimer propuseram como marco interpretativo capaz de efetuar uma releitura crítica do projeto original da Ilustração e de suas instituições políticas e culturais foi elaborado exclusivamente em termos de uma teoria do fascismo e uma teoria da cultura de massas, que tinham que servir como único horizonte explicativo da nova fase do capitalismo para o conjunto de seus aspectos: econômicos, psicológicos, políticos e culturais ( $C f r$. Habermas, 1987a: 465 e ss.; Honneth, 1995: 67-69).

Weber tinha antecipado o "destino trágico" das formas modernas de vida, ao vincular a progressiva liberdade frente à natureza que o desenvolvimento das forças produtivas fazia possível e a firme universalidade da igualdade formal dos cidadãos frente à lei garantida pelo Estado moderno, com um processo "inexorável de burocratização crescente", que era capaz de reverter em seus contrários ambos os ganhos (liberdade e

\footnotetext{
${ }^{16}$ Ver Derlien, H., "Bureaucracy in Art and Analysis: Kafka and Weber", in: Journal of the Kafka-Society of America № 15, 1991.
} 
igualdade) das formas tipicamente modernas de socialização. ${ }^{17}$ Apesar de se pensar, frequentemente, que esta tese depende de uma convicção pessoal ou de um olhar cético acerca de seu tempo, é, em realidade, sua sociologia do poder a que obriga Weber a fundamentar esta associação trágica. Pois é por meio dela que Weber deixa para trás a análise da distribuição do poder surgida do "espírito das leis" do Estado moderno, para se concentrar no exercício efetivo do poder, ciente de que "o verdadeiro domínio não consiste nem nos discursos parlamentares, nem nas proclamas dos monarcas, mas no controle diário da administração". ${ }^{18}$

A possibilidade de exercer o controle diário da administração não depende, em princípio, das qualidades intrínsecas do mandato que pretende conseguir obediência, mas sim da disposição daquilo que Weber denomina "aparelho" (Apparat) de dominação, constituído basicamente por "um conjunto de pessoas acostumadas a obedecer aos mandatos dos chefes" que participam cotidianamente no mando, fazendo-o valer por meio de diversos mecanismos (coativos e persuasivos) orientados à "conservação da dominação". ${ }^{19}$ O aparelho é, para Weber, a instância "secreta" do poder, aquela que revela os bastidores de todos os tipos de dominação, posto que nele se reúnem os diversos tipos de legitimidade com as formas da violência que os fazem possíveis. ${ }^{20}$ Neste sentido, o aparelho não deve ser entendido nem como o signo pelo qual é reconhecida a autoridade, nem como a atribuição que lhe é concedida, nem como o direito que a constitui, mas sim como o corpo efetivo da dominação (legítima). Esse corpo mantém uma relação de concordância ou adequação formal com a legitimidade da qual depende, e uma relação de eficácia material com a sujeição que produz. Deste ponto de vista, uma sociologia do poder não pode encarregar-se, exclusivamente, de elaborar uma taxonomia dos tipos de

\footnotetext{
${ }^{17}$ Para o que segue, que reúne o resultado da teoria da dominação "mediante uma organização" e da teoria da "dominação burocrática", ver: Weber, M., Economía y Sociedad, ed. FCE, México, p. 704-752 e 10601076.

${ }^{18}$ Weber, M., op. cit., p. 1060 (as itálicas são nossas).

${ }^{19}$ Weber, M., op. cit., p. 705.

${ }^{20}$ Um excelente estudo desta imbricação entre legitimidade e violência, assim como de suas implicações para a filosofia política contemporânea, pode ser encontrado em: Grüner, E., Las formas de la espada, ed. Colihue, Bs. As., 1997.
} 
dominação a partir da análise do direito, das atribuições ou da identidade de quem exerce o poder, mas deve ser capaz de vincular esses tipos de dominação com o aparelho que os faz funcionar.

Ao incluir a instância do aparelho na sociologia do poder, Weber pode conceber lógica e historicamente - formas de obediência racional-legalistas que, sem deixar de existir como tais, procedem de mecanismos de controle e de formação dos homens que operam através de outros meios (que são sempre formas da violência, seja esta explícita, implícita, física, simbólica, presente ou futura), encarregados de "fazer lembrar diariamente" aos cidadãos onde estão seus interesses reais e seus direitos legítimos, de modo tal a lhes facilitar os limites dentro dos quais é possível realizar a eleição e a aceitação livre das normas a que irão obedecer "como se se tratasse de sua própria vontade".

Para Weber, o único aparelho que concorda formalmente com a universalidade dos princípios político-morais de igualdade e liberdade, típicos do processo de modernização política, e que satisfaz o requisito de obter uma obediência autônoma e precisa a todos os mandatos sancionados corretamente (requisito imprescindível da economia capitalista), é o aparelho burocrático. Nem o Estado moderno nem a moderna empresa capitalista podem prescindir, pela multiplicidade e pela velocidade das informações e decisões que devem processar para alcançar satisfatoriamente seus fins, de um corpo administrativo altamente racionalizado, que só se realiza adequadamente por meio da constituição de um aparelho de dominação burocrático. Neste caso, a "administração" já não é uma parte ou um momento do tecido do poder (como era ainda quando se limitava a preparar o material e registrar os resultados das decisões que se tomavam em outras instâncias), mas sim a forma absoluta que adquire como forma específica de dominação. Suscetível de ser posta em prática em diversos contextos espaciais e materiais de organização, a forma burocrática de dominação se torna facilmente universalizável, e isto como consequência de suas principais características distintivas. Para Weber, em toda forma de dominação burocrática:

1. Vigora o princípio das atribuições oficiais fixas, ordenadas mediante leis ou disposições do regulamento administrativo, por isso se estabelece uma firme distribuição das atividades metódicas, fixam-se os poderes de mando 
necessários para o cumprimento desses deveres e se designam as pessoas aptas para o exercício permanente dessas funções.

2. Vigora o princípio da hierarquia funcional, quer dizer, um sistema de mando e subordinação mútua das autoridades, garantido pela inspeção das inferiores pelas superiores (e pela possibilidade, solidamente regulada, de apelar às decisões de uma autoridade inferior em uma instância superior).

3. Sua administração apóia-se em documentos públicos, registros e recursos que pertencem à organização, os quais estão nitidamente separados dos bens e recursos privados dos funcionários.

4. Sua atividade pressupõe uma conscienciosa aprendizagem profissional, que capacita para o desempenho de acordo com normas gerais fixas, mais ou menos completas.

5. Exige-se o máximo rendimento do funcionário, devendo este fazer "tudo" o que esteja a seu alcance para cumprir com as regras e as metas que lhe foram impostas. $^{21}$

Se, como afirmam reiteradamente Weber e os teóricos das organizações, a causa do progresso da organização burocrática "foi sempre sua superioridade técnica sobre qualquer outra organização",22, o que deve ser em seguida analisado são os supostos e os efeitos dessa "legitimidade técnica", fundamentalmente, em que medida a superioridade da organização burocrática, ao depender de sua capacidade para "extrair o máximo rendimento" de seus membros, pode acabar destruindo as condições subjetivas indispensáveis para a formação de uma ordem social legítima (no sentido que lhe atribui a sociologia compreensiva weberiana). As dúvidas, assim colocadas, não fazem mais do que

\footnotetext{
${ }^{21}$ Cfr., Weber, M., op. cit., p. 716-718.

${ }^{22}$ Weber, M., op. cit., p. 730-731: “Um mecanismo burocrático perfeitamente desenvolvido atua em relação às demais organizações da mesma forma que uma máquina em relação aos métodos não-mecânicos de fabricação. A precisão, a rapidez, a inequivocidade, a oficialidade, a continuidade, a discrição, a uniformidade, a rigorosa subordinação, a economia de atritos e de custos objetivos e pessoais são infinitamente maiores em uma administração severamente burocrática, e especialmente monocrática, servida por funcionários especializados, do que em todas as demais organizações de tipos colegial, honorífico ou auxiliar".
} 
ressaltar um paradoxo que se localiza no núcleo da organização burocrática de qualquer prática social. Toda tramitação burocrática consegue, com efeito, que a atividade dos homens produza resultados mais rápidos, precisos, unívocos e contínuos, em comparação com os resultados que produziriam esses mesmos homens organizados de outra maneira. Sob este aspecto, a coordenação burocrática das ações de cada um dos membros de uma organização permite um grau de potência coletiva superior ao de qualquer outro tipo de organização. E é neste sentido que a legitimidade (técnica) da burocracia pode afirmar-se, demonstrando que este tipo de dominação das interações humanas consegue "extrair o máximo rendimento dos funcionários”. Mas, paradoxalmente, a condição de precisão, rapidez, continuidade e univocidade do processo burocrático depende de uma rígida instituição de regras previsíveis, que despotenciam o sujeito, ao impedir a intervenção dos afetos, das convicções, das preferências (e, inclusive, da maioria de suas eleições racionais autônomas), que necessariamente são considerados, nesse marco organizativo, como "elementos irracionais" e "fontes de erro" ${ }^{23}$. Para o sujeito/funcionário, o princípio organizativo de sua profissão é regido pela máxima "sine ira ac studio", pela qual se vê "moralmente" obrigado a neutralizar sua personalidade (afetiva, moral, estética, intelectual) enquanto dure o movimento contínuo do processo burocrático. ${ }^{24}$

\footnotetext{
23 "A peculiaridade da cultura moderna, especialmente sua subestrutura tecnicoeconômica, exige esta «previsibilidade» ou calculabilidade do resultado. [...] Sua peculiaridade específica, tão bem-vinda para o capitalismo, desenvolve-a tanto em maior grau quanto mais se "desumaniza», quanto mais completamente alcança as peculiaridades específicas que lhe são contadas como virtudes: a eliminação do amor, do ódio e de todos os elementos sensíveis puramente pessoais, de todos os elementos irracionais que se subtraem ao cálculo." Weber, M., op. cit., p. 732.

${ }^{24}$ Weber repete aqui, en termos "pessimistas", a distinção (e o conflito) kantiana entre uso público e uso privado da razão: "Um funcionário - digamo-lo uma vez mais - que recebe uma ordem en sua opinião equivocada, pode - e deve - formular reparos. Porém se o superior ierárquico mantem-na apesar disso, então o dever do funcionário, e não só seu dever mas tambén sua honradez, estão em executá-la como se correspondesse à sua convicção, mostrando com isso que seu sentido de dever inerente ao cargo está acima de seu amor-próprio." Weber, M., op. cit., p. 1076. No conjunto de sua obra as dúvidas de Weber parecem dirigir-se à possibilidade de que sujeitos sem potencial em sua "esfera privada" de atividade e "acostumados à obediência" possam fazer um "uso público da razão", exercendo uma posição decidida orientada por suas convicções e suas próprias opiniões. De onde tirariam esses sujeitos a matéria e a força para intervir autonomamente na esfera pública? A resposta de Weber, que é material e historicamente mais rica, parece contradizer as ilusões que a exposição de Kant ainda contém: “A experiência mostra que uma remuneração segura, unida à probabilidade de uma carreira que não depende puramente do azar e da arbitrariedade, uma disciplina e uma inspeção rigorosas que respeitem o sentido da honra, assim como o desenvolvimento
} 
Esta paradoxal conjunção, contida no tipo "administrativo" de produção e integração social, que reúne um máximo rendimento do sujeito com a despotenciação radical da subjetividade, acende o alarme e dá forma ao momento kafkiano da teoria da racionalização moderna weberiana (continuado logo - segundo Habermas "unilateralmente" por Adorno e Horkheimer na Dialética da Ilustração). Por meio de uma analogia com o mundo dos aparelhos mecânicos ("espírito coagulado"), Weber pensa a organização burocrática como uma "máquina viva", que trabalha unida à máquina morta para "forjar o molde daquela servidão do futuro à qual talvez os homens sejam obrigados a se submeter, impotentes, se uma administração boa do ponto de vista puramente técnico chega a representar para eles o valor supremo e único que decida sobre a forma de direção de seus assuntos". 25

Assim, Weber justifica este temor nem tanto pela neutralização do sujeito que a dominação burocrática produz, mas, sobretudo, pela neutralização que a máquina viva da administração induz no contexto social ao qual se aplica e nas tradições histórico-culturais que reproduz. Por definição, um aparelho administrativo só funciona como tal se consegue tornar-se "indiferente" frente às mudanças que se possam suscitar na sociedade e frente às tradições culturais de seus membros. Esta indiferença (que permite que um mesmo organismo burocrático se encarregue de abastecer de "água ou segurança" a uma cidade, sem importar se esta continua sendo governada por suas "autoridades legítimas ou pelo general que conduz as tropas inimigas que acabam de tomar o controle de um país") transforma necessariamente os estilos de vida, as relações sociais e os valores culturais aos quais se aplica, em um meio ambiente homogêneo, completamente neutro, do qual a administração extrai demandas e informações e ao qual devolve um resultado eficaz, calculado e previsível. Esta naturalização do social e da cultura (que Lukács chamará “segunda natureza") resulta-lhe tão indispensável à empresa capitalista e ao Estado

da condição de honra e da possibilidade de uma crítica pública, oferecem as maiores oportunidades para alcançar e conservar uma rigorosa mecanização do aparelho burocrático, de tal sorte que funcione então mais seguramente que qualquer regime baseado na escravidão. O caráter profissional puramente "objetivo» do cargo, com sua separação em princípio entre a esfera privada e a que afeta sua atividade oficial, facilita a incorporação nas condições objetivas, dadas de uma vez por todas, do mecanismo fundado na disciplina". Idem., p. 726.

${ }^{25}$ Weber, M., op. cit., p. 1074. 
moderno quanto a despersonalização de seus membros, fazendo do entrelaçamento progressivo desta tripla despotenciação (do sujeito, da sociedade e da cultura) o fundamento de uma ordem social "administrativamente (re)produzida".

Se voltarmos agora ao nosso assunto inicial, referido à rejeição habermasiana do diagnóstico de Adorno e Horkheimer acerca do capitalismo tardio, bastará pensar, no momento, que o que lá se critica não é mais do que a generalização do campo suscetível de ser analisado sob a ideia weberiana de racionalização burocrática. A rejeição pode formular-se, então, nos seguintes termos:

1. Weber observa (e critica) uma tendência, inerente ao tipo moderno de racionalidade, orientada à expansão da forma burocrática de dominação para as esferas da política e do mercado (que progressivamente deixariam de estar dirigidas por um Eu capaz de dar um sentido socialmente orientado a seus atos e de se fazer responsável pelas consequências destes).

2. Adorno e Horkheimer elaboram um diagnóstico da sociedade de seu tempo que encontra essa mesma racionalidade burocrática em todos os estilos de vida, relações sociais e valores culturais efetivamente vigentes. Como consequência desta constatação, chamam "mundo administrado" à fase das sociedades capitalistas na qual a racionalidade burocrática se tornou total.

No que se refere ao uso e ao valor descritivo do conceito de "mundo administrado" (verwalteten Welt), a colocação habermasiana resulta plausível e pode ser verificada facilmente em distintos textos, fundamentalmente de Adorno, que começam a falar de música administrada (Adorno, GS 16: 17), sonhos administrados (Adorno, GS 15: 31), ouvintes administrados (Adorno, GS 14: 185), pensamento administrado (Adorno, GS 11.1: 28) e até caridade administrada (Adorno, GS 4: 46). A imagem que constrói Adorno para compreender o plexo vital do capitalismo tardio sustenta-se em um uso metafórico e estendido da ideia de coisificação (Verdinglichung) de Lukács (que já continha a tripla neutralização do sujeito, da sociedade e da cultura das teses weberianas), que apresenta, por um lado, um estendido processo pelo qual "todas as manifestações da vida ficam a serviço de sua extrema antítese" (MM: 26) e, por outro lado, todas as instituições que deveriam 
acolher os homens tornaram-se "frios albergues" (kalte Herberge) das práticas humanas, onde "a ninguém importa já nada", posto que o cuidado que se lhes pode exigir é, exclusivamente, o "da prisão e da clínica, onde o sujeito é administrado como um objeto" (MM: 130-131). Nesta descrição adorniana, o processo de racionalização parece já não mais mostrar um limite em relação a outro mundo, não-mecanizado - como o que revelava ainda, para Weber, a luta entre o "político diletante" e o "funcionário profissional". No conceito de mundo administrado parece afirmar-se que a racionalidade e o domínio burocrático abarcaram tudo. ${ }^{26}$

Para rejeitar este diagnóstico sombrio, que se refere, em definitivo, a "uma questão de fatos" e à capacidade de conhecer esses fatos, Habermas utiliza três linhas de argumentação diferentes.

Seu argumento mais fraco é aquele que pretende "compreender" Adorno e Horkheimer, pondo-se no lugar deles e explicando seus exageros a partir do contexto de enunciação em que foram pronunciados. Nesta linha de argumentação, os enganos e as simplificações atribuídas ao diagnóstico sombrio a respeito da modernização derivam da trama de acontecimentos sinistros que serviam de contexto enunciativo à escrita da Dialética da Ilustração, e deveriam dissipar-se com a superação destes mesmos acontecimentos. ${ }^{27}$ A "incapacidade de ver" a complexidade intrínseca do processo de modernização é entendida como resultado de um contexto que tornava impossível um olhar matizado do conjunto de suas determinações, pois o que estava na ordem do dia, o traço que se impunha ao observador, eram os efeitos violentos da degeneração da razão em "razão instrumental". Quando Adorno e Horkheimer decidiram lançar um olhar amplo sobre o processo de modernização, a partir do prisma que oferecia fenômenos como a

\footnotetext{
${ }^{26}$ Algo semelhante havia sido constatado na profecia negra de Ernst Jünger, para quem a modernização europeia havia entrado definitivamente em uma nova era com os aprestos militares da primeira guerra mundial. Na mobilização que a organização dessa guerra implicou já não havia - para Jünger - "nenhuma atividade - nem sequer a de uma empregada doméstica que trabalha em sua máquina de costura - que não destine sua produção, ao menos indiretamente, à economia de guerra. A exploração total de toda a energia potencial, que se exemplifica nessas oficinas de Vulcano construídas pelos estados industriais em guerra, sem dúvida revela da maneira mais significativa que estamos às portas da era do trabalhador, e esse confisco radical faz da guerra mundial um acontecimento histórico que supera em importância a Revolução Francesa”. Jünger, E., “Die Totale Mobilmachung”, in: S.W. 7, 1930, p. 130.

${ }^{27}$ Honneth prossegue nesta mesma linha argumentativa em Honneth (1995): 70 e ss.
} 
burocratização completa da economia, o totalitarismo político e a destruição da cultura gerada por sua transformação maciça em entretenimento e espetáculo, caíram necessariamente no engano de generalizar o que tinham frente a seus olhos. E foi essa generalização a que lhes impediu de ver que, junto com a linha regressiva que conduzia da revolução industrial a Auschwitz, existia também uma difícil linha evolutiva que, partindo das lutas sociais do século XVIII, chega até à consolidação da democracia constitucional e à plena vigência jurídica dos direitos humanos. Nesta explicação, o contexto "excepcional" funciona como a causa da impossibilidade de uma apropriação da totalidade das determinações "normais" do processo de racionalização, pois esse contexto carregava uma pesada unilateralidade, da qual eles teriam sido vítimas involuntárias. Aqui não nos vamos deter neste argumento, que é, sem dúvidas, o mais fraco de Habermas. Podemos adiantar nossos reparos, entretanto, não só em relação à duvidosa distinção que Habermas realiza entre momentos normais, carregados de possibilidades para um saber diferenciador, e momentos excepcionais, carregados de cegueira e unilateralidade, mas também em relação à hipótese implícita nessa leitura, que supõe que Adorno e Horkheimer foram completamente incapazes da mais mínima distinção entre as linhas "evolutivas" e as linhas "regressivas" da modernidade. A única coisa que a "Dialética da Ilustração" afirma com respeito a isso é que as linhas regressivas da modernidade fazem parte do mesmo processo que contém as linhas evolutivas ou, melhor dizendo, que os momentos excepcionais também pertencem ao funcionamento normal da racionalidade efetivamente personificada nas práticas sociais, que são seus momentos e que, portanto, situar-se neles permite uma interpretação tanto ou mais ampla do processo de modernização que a que se pode dar nos momentos de quietude institucional.

O segundo argumento de Habermas combina resultados de estudos empíricos realizados com posterioridade à "teoria clássica" acerca da burocracia, com uma demonstração pelo absurdo das teses que sustentam a possibilidade - inclusive a possibilidade lógica - de uma integração total dos homens na lógica das organizações administrativamente controladas. O estudo que utiliza Habermas demonstra, a partir da análise de resultados empíricos obtidos em diversas organizações estatais, que a objetivação rígida dos regulamentos, do planejamento das atividades e da manutenção das relações de subordinação não se dá, na prática, tal como a teoria da racionalidade burocrática o 
estipula. $^{28}$ Com este material empírico, Habermas pretende rejeitar não só a tese adorniana - que tinha generalizado a teoria da racionalização, mas também a própria reconstrução da racionalidade burocrática desenvolvida por Weber (mostrando que inclusive dentro da organização burocrática não se dá o tipo de neutralização da personalidade, do contexto social e das tradições culturais a que essa teoria atribui influência sobre o mundo externo da organização). Embora Habermas compartilhe da importância da observação weberiana, que destaca uma crescente autonomização da racionalidade organizativa e de controle que surge com o capitalismo, tanto no nível das empresas quanto da administração estatal, assume, por outro lado, o diagnóstico que afirma que essas organizações nunca poderiam conseguir reproduzir-se se seus membros perdessem efetivamente, como a tese weberiana parece afirmar, a vontade livre, as faculdades cognitivas ativas e a capacidade de sustentar relações situadas com os outros e com seu entorno. Por isso, a ideia de uma "administração total" resulta-lhe uma ideia interessante, enquanto assinala uma tendência que a teoria social crítica deve considerar relevante, mas logicamente absurda, dado que, de ser certa a intensidade absoluta do controle que pretende demonstrar, tornar-se-ia impossível a reprodução da organização cuja severa e contínua existência se propõe criticar.

Para responder ou, inclusive, expor esta discussão em termos que façam justiça a seus argumentos, seria necessário apelar a uma série de detalhes e materiais nos quais não nos podemos deter aqui. Em primeiro lugar, seria necessário recolher outros estudos empíricos, para confirmar ou para enriquecer os pontos da discussão que se referem à

\footnotetext{
28 “Em todo caso temos podido demostrar que tal objetivação resulta problemática em vista de como se desenvolve o trabalho efetivo nas organizações estatais:

-no aspecto cognitivo, os contextos local e histórico da ação social obrigam a quem trabalha em tais organizações a um papel ativo em ponto a definições e interpretações;

-no aspecto social, a aplicação das regras de ação em contextos sociais de menor ou maior amplitude tem que se orientar conforme a situação;

-no aspecto motivacional, resultam insustentáveis, precisamente nas organizações estatais, as hipóteses acerca de uma motivação ou uma suscetibilidade de motivação orientadas somente a valores de câmbio, isto é, de tipo inteiramente impessoal.

Wolff, St., "Handlungsformen und Arbeitssituationen in: staatlichen Organisationen", citado em Habermas (1987b): 440.
} 
forma, ao grau e à extensão efetiva da "racionalidade burocrática" dentro das organizações burocráticas. O que, nesse caso, podemos fazer é esclarecer em que medida, e seja qual for o resultado dessa discussão, ela não permitiria refutar por completo o diagnóstico a respeito do mundo administrado. Observando-se atentamente, vê-se que tanto por meio do material empírico analisado, quanto da demonstração pelo absurdo a que apela Habermas, o que se propõe é afirmar que a teoria da racionalização burocrática é falsa porque supõe a anulação de uma série de faculdades nos membros e nas próprias organizações que, por um lado, não se pode comprovar na realidade e, por outro, a dar-se tal como a teoria o propõe, significaria o fim da existência dessas organizações. Frente a isso, é importante destacar inclusive para fazer justiça à teoria weberiana - que as teses acerca do caráter opressivo e expansivo da racionalidade burocrática nunca afirmaram que, sob o império desse tipo de racionalidade, deixem de existir a vontade autônoma, o conhecimento acumulado pelas tradições culturais e as interações situadas. O que essas teses afirmam é que, sob esse tipo de racionalidade, a vontade pessoal, a capacidade de sustentar relações com o contexto social mais amplo e de se reapropriar criativamente das tradições culturais compartilhadas são, direta ou indiretamente, postas a serviço da finalidade objetiva autônoma que as subsume ao interior da organização burocrática. Tanto para Weber como para Adorno, é evidente que a racionalidade administrativa necessita que seus membros não sejam "autômatos"; mas o necessita para poder utilizar esses graus de liberdade com o objetivo de conseguir o melhor rendimento de uma atividade que foi calculada e sistematizada sem eles e que existe objetivamente além de sua vontade e seu conhecimento.

Habermas constrói seu melhor argumento contra o conceito de "mundo administrado" quando não procura compreender os limites dessa teoria a partir do contexto, e quando não se concentra numa refutação empírica de alguns dos supostos da teoria da racionalidade burocrática na modernidade. Nesta outra linha de argumentação, o que Habermas destaca é uma insuficiência das ferramentas conceituais com as que contaram Weber, Adorno e Horkheimer para efetuar um diagnóstico das transformações que se estavam produzindo no capitalismo do século XX, em sua estrutura econômica e política, por um lado, e, por outro, nos conteúdos cognitivos, normativos e apreciativos que a modernização cultural trazia consigo. O que, neste caso, Habermas tenta demonstrar é que o conceito de "mundo administrado" não pode compreender adequadamente o que, num 
plano descritivo, consegue tornar manifesto, conseguindo destacar um conflito constitutivo da modernização que outras teorias da sociedade não logram formular. ${ }^{29}$ A pista para reconstruir, a partir de um horizonte conceitual melhorado, a compreensão truncada das patologias sociais do capitalismo tardio continua sendo a intuição que refere uma progressiva perda de liberdade e sentido. Mas, se no diagnóstico de Weber essa perda era atribuída a um sujeito que era capaz de experimentá-la como uma lesão de sua liberdade para gerar, com autonomia, atos socialmente orientados, e como uma impossibilidade para se reconhecer a si mesmo no sentido objetivo das instituições e inter-relações que enquadram sua existência individual; para Habermas, essa perda já não pode ser explicada utilizando o modelo da constituição subjetiva do sentido e exige uma nova fundamentação da teoria da ação (que considere a distinção entre ação instrumental e ação comunicativa) e uma revisão profunda da teoria da sociedade (que permita pensar a diferença entre integração sistêmica e integração social). Resulta evidente que a mudança de paradigma teórico proposta por Habermas decide-se nas implicâncias desta crítica. Aqui, só queremos ressaltar como se situam as colocações de Weber, Adorno e Horkheimer frente a essa crítica.

O que aparece, em primeiro lugar, é a necessidade de determinar o caráter colateralmente patológico da burocratização das sociedades modernas, de um ponto de vista que seja mais sólido que aquele da filosofia do sujeito, que ainda serve de fundamento para a teoria da ação e da racionalidade weberiana. ${ }^{30}$ A crítica explícita que Habermas faz ao paradigma weberiano é que este considera as patologias sociais da razão do ponto de vista exclusivo de um indivíduo monadológico que, no final, resulta incapaz de explicar a complexidade do sistema social em relação ao qual se sente subjetivamente vítima. A racionalidade dessa subjetividade monadológica deveria ser colocada, pelo contrário, - e neste ponto Habermas concorda com Adorno e Horkheimer - do lado daquilo que a crítica

\footnotetext{
${ }^{29}$ Ver Habermas (1987b): 429-443.

${ }^{30}$ A necessidade prioritária de superar os impasses que a filosofia do sujeito gerava no centro do projeto da teoria crítica não deveria obscurecer a necessidade sociológica que este distanciamento de Habermas supõe. Para uma teoria da sociedade como a sua, que depende de um conceito forte de aprendizagem cognitiva e normativa, a estimada evidência do aumento dos rendimentos coletivos que mostram as instituições modernas regidas pela racionalidade burocrática não pode ser de nenhum modo lançada em massa no terreno da suspeita.
} 
da ideologia deveria desmascarar, em vez de ser posta, em termos idealistas, como um pressuposto puro de liberdade e sentido. Ao fazer isto, o que fica claro é, finalmente, que resulta impossível falar de patologias sociais da razão sem uma teoria da sociedade que seja suficientemente compreensiva acerca da complexa articulação de suas partes para poder elaborar esse diagnóstico sem atribuir-lhe ao termo patológico um sentido unilateral ou puramente psicológico - perigo que, em seu momento, o próprio Weber já tinha denunciado. Não sendo possível construir essa teoria do ponto de vista do sujeito monadológico, resulta evidente, para Habermas, que o que a intuição acerca da perda de liberdade e sentido exigia era outro fundamento filosófico para a ideia de racionalidade, um fundamento filosófico "dialógico" que, segundo seu ponto de vista, pode ser encontrado nas estruturas (pragmático-universais) da linguagem intersubjetiva.

Este fundamento dialógico, que vai aparecer com força em sua reapropriação do conceito de "mundo da vida" da fenomenologia social, permite-lhe agora repensar o conteúdo da intuição crítica acerca do processo de modernização do qual compartilham Weber, Adorno e Horkheimer, a partir de uma teoria social mais complexa, que considera como inerente a todo processo de modernização a "diferenciação entre sistema e mundo da vida" (Habermas, 1987b: 451) e descobre o verdadeiro campo do patológico exclusivamente na "colonização" da estrutura comunicativa do segundo a partir da lógica administrativa de controle do primeiro. A partir desta distinção, "o social não fica, de forma alguma, absorvido como tal pelos sistemas organizados de ação" e confrontado, então, drasticamente com a instância do sujeito, mas "fica dividido em âmbitos de ação constituídos como mundo da vida, e âmbitos de ação neutralizados frente aos mundos da vida" (Habermas, 1987b: 438), de tal modo que a experiência de uma racionalidade subjetiva danificada explica-se, agora, a partir de uma teoria que encontra, nas sociedades modernas, um conflito e uma tensão permanente entre âmbitos de ação socialmente integrados e âmbitos de ação sistemicamente integrados. ${ }^{31}$

\footnotetext{
31 "O mecanismo do entendimento linguístico [característico do mundo da vida], essencial para a integração social, fica parcialmente em suspenso nos âmbitos de ação sistemicamente organizados, e descarregado [de sua função estruturante] por via de mecanismos de controle. Estes últimos, não obstante, têm que ficar ancorados no mundo da vida por meio do direito formal. Daí que o tipo de juridização das relações sociais seja um bom indicador dos limites entre sistema e mundo da vida." Habermas, (1987b): 438.
} 
Mas, com esta reconstrução, Habermas não só descarta do campo da teoria crítica da sociedade o fundamento subjetivo que sustentava a teoria da racionalização weberiana (e, junto com ela, a teoria hermenêutica e as filosofias da linguagem que atribuem um rol desproporcionado, na explicação do processo de reprodução social, à ação subjetiva orientada para a renovação permanente do entendimento linguístico), mas também anula a possibilidade de começar a partir do outro lado da relação coisificada, o lado do objeto, a reconstrução de uma teoria da sociedade que esteja à altura dos desafios interpretativos do processo acelerado que sofreu a modernidade durante o século $\mathrm{XX} .{ }^{32} \mathrm{O}$ fato de que este era o caso do trabalho filosófico e cientifico de seu mestre, só assinala um ponto adicional da divergência que existe entre ambos.

Como tentaremos demonstrar na segunda e na terceira parte deste trabalho, com o lema conhecido como Vorrang des Objekt, Adorno indicou um caminho preciso para criticar a ideologia subjetivista no campo da arte e da filosofia que deve ser considerado como prioritário para essa discussão no campo das Ciências Sociais que propõe Habermas. Sua teoria da intersubjetividade comunicativa pode aparecer sob essa iluminação adorniana como outra forma da ideologia subjetivista na teoria, que carrega falsos princípios à consideração referida às relações fundamentais de associação entre os homens e ao processo de formação dialógico da Razão. ${ }^{33}$

b) A radicalização "sem rumo" da análise das patologias sociais

O discurso filosófico da modernidade é, sem dúvidas, o livro mais polêmico de Habermas (e talvez por isso mesmo um dos mais interessantes). A estratégia de leitura do

${ }^{32}$ Com esta resistência a depositar no polo do sujeito ou no polo do objeto a crítica à tendência à racionalização burocrática do mundo moderno, Habermas procura evitar que as alternativas a esse processo tenham que ser encontradas necessariamente na duvidosa figura do "líder carismático" (o sujeito "que se opõe à racionalização burocrática" em Weber) ou na misteriosa relação "mimética com a natureza" (que Adorno propõe como alternativa à relação instrumental). Nenhum desses potenciais críticos parece-lhe adequado, justo e relevante para uma teoria crítica da sociedade que seja capaz de explicar os dilemas do capitalismo tardio.

${ }^{33}$ Ver Adorno (PE): 100 e ss. 
seu cenário teórico consiste em confrontar as pretensões do discurso filosófico sobre a modernidade com os avanços produzidos na modernidade no campo da teoria da sociedade. O que Habermas tenta demonstrar com este choque de perspectivas é que a maioria das posições filosóficas que procuraram desembaraçar-se criticamente da razão moderna durante o século XX o fez sem chegar a uma plena compreensão dos fundamentos sociais das distintas formas de racionalidade que a modernidade necessariamente promove, e que, por conta disso, esses discursos (pós-modernos) só criticam a partir de uma distância estéril (e do desconhecimento da sua atualidade efetiva). Nesta perspectiva, levando em conta os erros e unilateralidades do diagnóstico sombrio sobre as sociedades pós-liberais que encontra em Adorno e Horkheimer, Habermas nem mesmo vacila em associar sua produção teórica ao tipo de discurso filosófico que ele se propõe criticar neste livro. Na articulação de seus capítulos, Habermas vai mostrar como esses erros de diagnóstico são os responsáveis por uma radicalização nociva na interpretação filosófica, que já não vai conseguir vincular teoricamente as patologias sociais do processo de modernização às dificuldades de auto-fundamentação de uma racionalidade emancipada de prejuízos e interesses de domínio encobertos.

O núcleo da crítica de Habermas afirma que Adorno e Horkheimer, presos na escrita dos "pensadores negros" da modernidade (Sade, Nietzsche e o próprio Kafka), avançaram no caminho de uma dilaceração da razão subjetiva a partir dos pressupostos de uma racionalidade objetiva que eles mesmos consideravam insanavelmente caduca. Daí a posição paradoxal de todo seu projeto teórico. Para eles, a grande filosofia, que implicava "a idéia de reconciliação entre natureza e espírito" (e que tinha sucumbido junto com as imagens religioso-metafísicas do mundo), continuaria cumprindo, sugere Habermas, a função de lugar-tenente da promessa de uma situação "verdadeiramente humana", inclusive quando já não podiam ser demonstradas de nenhuma maneira suas pretensões de verdade. Neste sentido, o programa da teoria crítica só podia procurar sob suas ruínas (onde jazem os restos produzidos pela objetivação da forma mercadoria e o Estado burguês) a verdade subterrânea capaz de lhe dar ao pensamento sua força negadora e sua capacidade para transcender a "coisificação da razão". 
Com este tipo de reconstrução dos dilemas da Razão, Adorno e Horkheimer posicionam-se frente à interpretação crítica da filosofia moderna elaborada por Lukács em termos ambivalentes ${ }^{34}$ :

1. Por um lado, rechaçam a idéia de Lukács que afirma que a racionalização tem um limite objetivo em seu próprio caráter formal, o qual se expressa tanto socialmente (mediante a crise econômica) quanto subjetivamente (na consciência revolucionária do proletariado). Este rechaço dava-se tanto em termos empíricos - analisando a penetração da coisificação na cultura e a natureza interna dos indivíduos socializados sob o capitalismo tardio - , como em termos teóricos - demonstrando que a confiança na racionalidade imanente da história reproduz um tipo de filosofia (da identidade) que é precisamente aquele que a crítica da consciência coisificada queria combater.

2. Por outro lado, radicalizam de tal modo a crítica lukacsiana da coisificação que já não consideram ser a racionalização integral do mundo apenas «aparente», e necessitam, em conseqüência, de uma conceituação que lhes permita nada menos que qualificar o «todo» de falso".

3. A partir do anterior, terminam invertendo o diagnóstico sobre a coisificação, atribuindo agora ao pensamento identificador da razão subjetiva $a$ causa da formalidade abstrata do intercâmbio mercantil e suas formas (objetivas e subjetivas) derivadas. (Habermas, 1987a: 481)

Para Habermas, é este último movimento o que provoca o "extravio" da Dialética da Ilustração em relação ao programa de uma crítica ideológica da racionalidade moderna, que Lukács tinha conseguido construir no caminho do pensamento de Marx. Ao radicalizar a crítica, Adorno e Horkheimer oferecem uma versão tão abstrata da estrutura da coisificação que esta pode fazer-se extensiva não somente à rígida forma teórica do racionalismo

\footnotetext{
${ }^{34}$ Ver, Habermas (1987a): 480 y ss.
} 
formal, mas também ao próprio pensamento identificador que serve ao homem para enfrentar teleologicamente a natureza no trabalho que realiza com o objetivo de sua reprodução. A análise da transformação patológica pela qual a razão transforma-se num instrumento de dominação inclui agora, num único conceito, não só o tipo de controle que a racionalidade burocrática exerce sobre os homens, mas também o controle que se exerce no trabalho sobre a natureza e a repressão da natureza interna que dá forma à identidade do eu individual. A diferença de Lukács, para quem a coisificação significava uma "coação que leva a assimilar as relações inter-humanas (e a subjetividade) ao mundo das coisas, coação que se produz quando as ações sociais já não são coordenadas através de valores, de normas ou do entendimento lingüístico, mas sim através do meio valor de troca" (Habermas, 1987a: 484), para Adorno e Horkheimer a análise do processo através de qual a razão transforma-se em uma força de domínio inclui, não só o mundo das ações dos sujeitos, mas também a modalidade de seu intercâmbio e apropriação da natureza externa e interna. Para Habermas, é esta radicalização na análise das patologias sociais da razão aquilo que torna virtualmente impossível a tarefa de elucidar uma nova "norma de verdade" no interior desse contexto, a não ser que se considere plausível a posição metafísica - de teor neoromântico - que pretende fazer efetiva uma forma de universalidade que dependa de uma reconciliação não só entre os homens, mas também deles "com a natureza, quer dizer, com os animais, as plantas e os minerais" (Habermas, 1987a: 485). Com esta leitura irônica, a crítica de Habermas à interpretação da Razão moderna de Adorno e Horkheimer dirige-se, por um lado, contra suas "abstrações e des-diferenciações" (Habermas, 1989: 140) e, pelo outro, contra as conexões e associações descontextualizadoras e desistorizadoras que essas abstrações provocam.

Na objeção anterior, o que está em questão é a determinação — via Nietzsche — do caráter essencialmente autodestrutivo da razão. Segundo essa interpretação, desde seus começos a razão, que opera como órgão do impulso de auto-conservação, realiza seus fins mutilando aquilo que se propõe proteger. Adorno e Horkheimer introduziram-se, por essa via, ao estender o problema da coisificação até o nível das pulsões do sujeito, longe do terreno histórico-social no qual o havia situado Lukács. Se for já ao nível da organização das pulsões onde se podem observar os efeitos da coisificação, então a história dos esforços específicos que tentaram dar forma à razão deixa de ter valor, já que essas formas só 
aparecem como variações de um mesmo mecanismo que procura controlar os impulsos do sujeito para adaptá-lo funcionalmente a um contexto vital incerto e perigoso. A generalização do processo de coisificação repercute, deste modo, necessariamente sobre a estrutura da racionalidade que se deve submeter à crítica. Neste caso, a razão só é entendida em termos a-históricos como razão instrumental, como vontade de poder que se utiliza das pretensões universais de verdade e de justiça tão somente para impor de maneira mais eficaz sua particularidade. E com isto, já não é mais possível criticar as pretensões historicamente constituídas de superar a parcialidade nas diversas formas do pensamento racional, posto que (toda) a razão "fica definitivamente despojada de sua pretensão de validez e assimilada ao puro poder" (Habermas, 1989: 142).

A referência a Lukács que utiliza Habermas para justificar sua própria crítica não é completamente desacertada. Apesar do modo diferente pelo qual cada um realiza a sua crítica, para ambos resulta imprescindível não confundir a reconstrução crítica da gênese (histórica, psicológica ou antropológica) do pensamento racional com a crítica de suas pretensões de validez, dado que esta última implica uma série de problemas que não podem ser reduzidos àquela (ainda que estejam profundamente vinculados). Quando Lukács ou Habermas criticam a posição ideológica da Razão moderna a partir de uma análise do processo social que teria que fazê-la efetiva, o que fazem não é criticar as pretensões universalistas de seus enunciados, mas sim a idéia de que essas pretensões tenham encontrado o modo para poderem ser adequadamente enunciadas e tenham conseguido valer efetivamente nas ações e as instituições humanas. Não estão pensando, portanto, que a razão tenha estado "sempre" ao serviço do engano, mas sim observam como, num determinado contexto histórico-social, a forma de racionalidade que efetivamente adquire validez entra necessariamente em conflito com suas próprias pretensões. A reconstrução genética serve para explicar as limitações reais que impedem que essas pretensões possam transformar-se num valor compartilhado pelos homens em suas distintas atividades, mas não serve para refutá-las em quanto tais, quer dizer, em quanto pretensões inscritas na forma de racionalidade que adquiriu efetivamente validez. Por sua relevância para nossa argüição posterior, resulta oportuno deter-se brevemente neste ponto. 
Formulada em seus próprios termos, a validez de toda norma requer — por mais reduzida que esta possa chegar a ser - uma instância transcendental (ou quasetranscendental) que funcione como uma espécie de teatro de operações virtuais, no qual suas expectativas normativas possam cobrar existência. ${ }^{35}$ Este teatro de operações virtuais revela de modo exemplar como deveriam comportar-se os homens para produzir uma proposição verdadeira, um ato justo ou uma apreciação adequada de algum objeto. As formas dessas operações podem ser das mais variadas. Também pode ser variado o grau de aceitação das regras que determinam essas operações. O que não pode faltar nunca é a cisão ( $n a$ realidade) que estabelece a diferença entre o modo de existência virtual daquilo que a norma espera que se faça e a existência efetiva sobre a qual essa expectativa recai. Essa distância é a que permite, em primeiro lugar, que uma vontade, um mandato ou uma máxima particular possam ser enunciados como tais; sendo também essa distância a condição, em segundo lugar, de que o sentido dessa vontade, desse mandato ou dessa máxima seja reconhecido pelos membros de uma sociedade com relativa independência de sua situação particular (e das restrições e motivações naturais que os determinam). Esta é a razão pela qual certa instância transcendental resulta indispensável para a existência da validez de uma norma, já que ela deve ser capaz de orientar efetivamente a ação social dos homens além das diversas situações nas quais estes se encontrem, podendo chegar a obrigálos internamente a seguir um determinado curso de ação, inclusive contra seu próprio desejo ou vontade particular. Num sentido mais restritivo, poder-se-ia afirmar que só deveríamos chamar "normas" socialmente válidas àquelas que conseguiram, com uma determinada continuidade, ao menos a probabilidade certa de obrigar internamente a os homens contra seu próprio desejo.

Algo que compartilham a maioria das teorias que defendem a necessidade de uma distinção enfática entre validez e faticidade é o fato de que as orientações da ação que são

\footnotetext{
${ }^{35}$ Para uma versão clássica y rigorosa de esta conceituação ver, Weber, M., Wirtschaft und Gesellschaft, Tübingen, 1922, pp. 13-20 y 122-176. Ao mesmo tempo, para deslindar seu significado sociológico de deu acepção jurídico-idealista, tal como foi postulada por uma parte do neo-kantismo ver, Weber, M., "R. Stammlers "Überwindung» der materialistischen Geschichtsauffassung", in: Archiv für Sozialwissenschaft und Sozialpolitik, Bd. 24, pp. 94-151 (recopilado por Marianne Weber ao interior dos: Gesammelte Aufsätze zur Wissenschaftslehre, Tübingen, 1922, pp. 291-359). Habermas oferece sua versão desta questão, certamente mais "racionalista" e "idealizadora" que aquela de Weber, em seu Excurso sobre teoría de la argumentación, in: Habermas (1978a): 43-69.
} 
suscetíveis de ser analisadas sob o conceito de validez não podem ser reconduzidas a nenhuma determinação natural dos indivíduos (grupos ou coletividades) que as realizam. Isto porque essas orientações operam como critérios de seleção e preferência que decidem sobre questões que são sempre mais específicas ou mais gerais, mais situadas historicamente ou mais atemporais do que aquilo que poderia ser dirimido a partir das indicações ou dos estímulos de sua pura faticidade natural. Sobre aquilo que decide uma norma - dirão - não resulta decisiva nenhuma explicação psicológica, neurológica, biológica, etc. Daí que a distância em relação à faticidade da vida seja uma das determinações essenciais do conceito de validez, sem que isto implique ou, ao menos, não implique necessariamente que deva aceitar-se uma separação ontológica entre o "reino da liberdade" e o "reino da necessidade".

Para fundamentar a necessidade da distância em relação à faticidade que supõe a esfera da validez normativa pode-se também utilizar a estratégia rickertiana para sublinhar o fato de que não dispomos realmente de nenhuma estrutura teórica que nos permita reduzir o que ambos os conceitos tornam inteligível. Ao interior do neo-kantismo, como é sabido, foi Rickert quem tentou demonstrar que o que esta por detrás da distinção entre validez e faticidade não é necessariamente uma diferença ontológica, mas sim, em primeiro lugar, uma diferença lógica que distingue dois interesses cognitivos diversos: o interesse pelo geral, pelo exaustivo, próprio das ciências naturais, e a inquietação pelo singular, por aquilo que não pode ser deduzido de uma teoria geral, própria das ciências da cultura. ${ }^{36} \mathrm{~A}$

\footnotetext{
${ }^{36}$ Por mais insatisfatória que possa resultar hoje sua posição sobre a historia e a cultura, sua influencia resulta evidente nas teorias contemporâneas das ciências normativas. Ver, especialmente, a fundamentação desta distinção em: Rickert, H., Kulturwissenschaft und Naturwissenschaft, Freiburg, 1899; e sua critica a idéia da "simplicidade" e a lógica "monista" das filosofias da vida em: Die Philosophie des Lebens, Tübingen, 1920. Ao criticar a interpretação da experiência estética nietzschiana, que rejeita a contraposição entre o principio vital (dionisíaco) e o principio normativo (apolíneo) na arte, afirma Rickert: "Dionisio, interpretado como o Deus dos instintos vitais puramente selvagens, não tem nenhum lugar na esfera estética. Para emergir através dela o, inclusive, para investir-se das menores ataduras, deve realizar esta tarefa mediante uma forma autenticamente artística." Rickert, Die Philosophie des Lebens, pág. 165. Weber tem colaborado com brilhantes nesta discussão ao longo de toda sua obra, porém, merecem ser destacados seus primeiros trabalhos metodológicos: Roscher und Knies und die logischen Probleme der historischen Nationalökonomie; Die "Objektivität" sozialwissenschaftlicher und sozialpolitischer Erkenntnis; y Kritische Studien auf dem Gebiet der kulturwissenschaftlichen Logik, in: Gesammelte Aufsätze zur Wissenschaftslehre, Tübingen, 1922. Recentemente, Habermas ha utilizado este problema como tema central da sua sociologia do direito. Ver, Habermas (2005).
} 
partir deste ponto de vista, não resulta imprescindível uma distinção metafísica - como a que Dilthey propôs por sua vez - para fundamentar a distância transcendental da esfera de validez normativa, já que a única coisa que se afirma é que resulta impossível compreender a especificidade da vida cultural a partir de um conceito onicompreensivo de vida natural. A existência de uma norma com pretensões de validez serve para demonstrar - diria Rickert - que existe $n a$ faticidade algo mais que a "mera faticidade" nomologicamente exposta. ${ }^{37}$

Pois bem, essa distância - qualquer que seja seu estatuto - em relação à faticidade da vida e à mera regularidade no fato de "seguir uma norma" não chegam a circunscrever sua esfera de validez. O específico de uma ordem normativa válida consiste em, que junto com a determinação do que deve ser realizado, venha dada uma justificação (racional ou irracional) de seu valor para os homens, quer dizer, que se dê também uma resposta à pergunta: por que devo reconhecer que são essas (e não outras) as operações que conduzem a um resultado verdadeiro, justo, etc.? Portanto, não basta a aceitação de fato do conteúdo da norma para que esta seja efetivamente válida ao interior de um grupo, uma classe ou uma sociedade determinada. O que a validez exige é a aceitação da justificação dessa norma, isto é, que a norma seja capaz de tornar-se obrigatória (verbindlich) para a ação porque o sujeito a considera como o modelo (Vorbildung) de uma ordem desejável, verdadeira ou justa. ${ }^{38}$ Esta exigência supõe que existe uma segunda distância, agora não já entre a faticidade e as expectativas normativas, mas sim entre essas expectativas e sua

\footnotetext{
37 "Vollends ist es nicht notwendig, daß wir die Lebenswirklichkeit zugunsten dessen, was mehr als Leben ist, metaphysisch zur bloßen Erscheinung entwirklichen. Wir halten an dem vitalen Leben als voller Realität fest und suchen trotzdem nach einer Welt, die das Andere des Lebens ist. Muß es in der Philosophie denn immer auf ein Entweder-Oder hinauskommen? [...] Was aber für den engeren Lebensbegriff gilt, könnte auch für den weiteren zutreffen. Es gibt zwar Leben gewiß nicht dann allein, wenn das Leben selber mehr als Leben ist, denn das wäre ein Widerspruch. Aber vielleicht gibt es Leben nur, wenn außer ihm etwas Anderes besteht, das mehr als Leben ist, und es gibt umgekehrt vielleicht mehr-als-Leben nur, wenn wir daneben das bloße Leben in seiner Selbständigkeit unangetastet lassen. Dann müßten wir sagen: das Leben ist der eine Teil der Welt, das überlebendige Mehr-als-Leben der andere Teil. [...] Den Lebensmonismus haben wir zu vermeiden. Wir sollten uns ebenso hüten, in einen Antilebensmonismus zu verfallen. Nur ein Denken, das heterologisch das Eine wie das Andere umspannt und in dieser , «Dualität» das Wesen der Welt erfaßt, kann wahrhaft universal werden, also zu einer umfassenden Philosophie führen." Rickert, H., Die Philosophie des Lebens, pp. 169-171. Pode encontrar-se um excelente estudo desta problemática e sua relação com a teoria weberiana em: Cohn, G., Crítica y resignación. Fundamentos de la sociología de Max Weber, ed. UNQ, 1998, pp. 91-104.

${ }^{38}$ Cfr., Weber, M., Wirtschaft und Gesellschaft, Tübingen, 1922, pág. 16.
} 
justificação, quer dizer, entre as orientações normativas da ação e as pretensões de validez das mesmas. Com esta segunda distância, toda ordem normativa válida demonstra que o sujeito adquiriu uma atitude reflexiva frente ao conteúdo das normas, por mais ínfima ou impotente que aquela logo resulte.

Para a teoria da racionalização das ordens de validez culturais, o grau zero desta distancia entre as normas e sua justificação (inexistente do ponto de vista histórico), constitui-lo-ia a pura tautologia da lei, que poderia ser formulada a partir do enunciado: “deve ser porque deve ser”. Esta ausência de distância entre a pretensão de validez e o conteúdo normativo explicita o vazio de sentido que toda justificação histórica de uma ordem de validez deve preencher, pois, do contrário, o sujeito não contaria com nenhuma distancia a partir da qual aderir como tal ao imperativo da lei. Por isso o primeiro nível efetivo de validez, que Weber faz depender da "legitimidade tradicional", pode ser entendido como o grau ínfimo dessa distância reflexiva: "deve ser porque foi sempre assim". ${ }^{39}$ No outro extremo, a situação hipotética que funcionaria como anulação da esfera de validez - mas agora devido ao caráter absoluto da distância entre o sujeito e a ordem normativa - dar-se-ia no caso em que se pretende que: "nada que não corresponda com a própria utilidade deve ser". Para Weber, este caso extremo tampouco seria localizável na história, já que inclusive a reprodução da vida de um grupo de indivíduos que pretendessem reger-se exclusivamente pelo princípio de utilidade exigir-lhes-ia aceitar a autonomia de um marco legal mínimo que permitisse dirimir suas diferenças com o menor custo possível. O que positivamente mostra este caso extremo é o sentido do processo da racionalização. Posto que quanto maior for a distância entre as pretensões de validez e as expectativas normativas, maior será a possibilidade de que intervenham, como condição para sua aceitação, novas séries de interesses, diferentes daqueles que estão efetivamente sancionados nas normas vigentes. Através desse hiato que ocorre entre as pretensões de validez e as expectativas normativas constitui-se a instância da racionalidade subjetiva, a qual é capaz de tornar controverso o sentido das normas a partir da consideração dos seus

\footnotetext{
${ }^{39}$ Cfr., Weber, M., Wirtschaft und Gesellschaft, Tübingen, 1922, pp. 17-20 y 122-126. Por mais limitada que seja esta justificação, sempre poder-se-á disser a favor do seu caráter não tautológico que a mínima distância que existe entre o "sempre foi assim" e o conteúdo de aquilo que "deve ser", é a que permite historicamente a luta pela interpretação do sentido das normas nas sociedades tradicionais. A partir deste ponto de vista, inclusive no grau mínimo da distancia entre as pretensões de validez y as expectativas normativas, o sujeito pode emergir em quanto instancia que é capaz de decidir sobre seu sentido.
} 
próprios interesses no plano da faticidade. Ao interior desta construção teórica, só se dirá de uma ordem normativa que é uma ordem regida por uma validez racional se for dada esta dupla condição que consiste no caráter abertamente controvertível das pretensões de validez e na emergência do sujeito que conhece seus próprios interesses para além do que lhe ditam as normas tradicionais.

Para o tipo de análise dos fundamentos sociais da Razão que praticam tanto Lukács como Habermas, resultam indispensáveis as implicações que traz a distinção entre a esfera de validez e a esfera da faticidade. ${ }^{40}$ Uma teoria do conhecimento que faz uso desta distinção (e que consegue fundamentá-la em uma teoria histórica da racionalização das

\footnotetext{
40 Por distintos caminhos, em este ponto ambos são weberianos ortodoxos, o que os leva a rechaçar drasticamente o tratamento puramente empírico das questões normativas e a quedar fortemente vinculados com a atividade política da sua época. Com a sobriedade de seu talento Weber pronuncio-se já em seus primeiros escritos em contra da redução dos problemas de validez a problemas de facticidad, tal como o fazia a psicologia experimental da sua época. Entre suas famosas intervenções na "polêmica sobre o método" das ciências humanas do final do século XIX e começo do XX, Weber referia-se à explicação psicológico-causal como uma "cicuta para la libre actividad del historiador" que levava a que o pesquisador se "engañase a sí mismo y a los otros con la falsa apariencia de la exactitud". Aquilo que resultava mais preocupante para Weber era o modo pelo qual disfrazavan-se diferenças normativas, que unicamente podem surgir de decisões, preferências y valorações, ao transformar-las em diferenças "naturais", inscritas nas qualidades das coisas nas quais a ciência acede passivamente. Ao interior desta polêmica o conceito psicologico-vitalista de "criatividade" foi um dos alvos privilegiados de sua crítica: "Según esta psicología, escribe Wundt, en el curso de todo desarrollo individual o general»-por lo tanto da lo mismo que se trate de un borracho, un maníaco sexual o un genio religioso- se producen valores espirituales (es decir, en su interpretación, lógicos, éticos y estéticos) «que originariamente no poseen las cualidades específicas que luego asumirán», puesto que, según Wundt, en el ámbito de los fenómenos de la vida, la ley del «incremento de la energía psíquica» forma parte del principio de la conservación de la energía física. Esta "tendencia» general a la formación de «magnitudes de valores crecientes» puede ser "total o parcialmente frustrada» por causa de "factores perturbadores», pero en todo caso, "una de las más importantes interrupciones del desarrollo psíquico: el cese de la actividad espiritual del individuo» -debe entenderse aquel fenómeno que normalmente, y de modo más simple, se suele llamar muerte-, «es más que compensada por el aumento de energía espiritual interna de la comunidad a la que el individuo pertenece». [...] Pero como es evidente que no sólo el profesor universitario, sino también el hombre de Estado y en general todo individuo experimenta un "desarrollo psíquico», surge la pregunta de para quién debe valer esta confortante relación «compensatoria». Es decir, ¿quién recaba una compensación «psicológica» por la muerte de César o de un honesto barrendero cualquiera: 1- el muerto mismo; o 2- su familia; o 3- aquellos a los que la muerte pone a disposición un «puesto» o bien les ofrece la oportunidad de «actuar»; o 4- el Ministerio de Hacienda; o 5- la oficina de recultamiento; o 6- ciertas corrientes de un partido político... o 7el orden de la providencia; o, para acabar: el metafísico psicologista?" Weber, M., Roscher und Knies und die logischen Probleme der historischen Nationalökonomie, in: Gesammelte Aufsätze zur Wissenschaftslehre, Tübingen, 1922, pp. 55-56. [Tradução José María García Blanco]
} 
sociedades) estabelece um duplo critério que impede que se possa rejeitar a validade de uma regra de verdade a partir dos obstáculos empíricos ou das deficiências que pudessem existir no sujeito psicológico para realizá-la plenamente. Para ambos, este duplo critério pode ser utilizado com êxito a partir da modernidade capitalista, porque, sendo tão recente quanto o racionalismo moderno, com ele as pretensões de validez da verdade tornam-se instáveis e abertamente controvertíveis, atribuindo ao sujeito uma potencialidade cognitiva que lhe permite fazer uso de seus pontos-de-vista contra as formas ritualizadas do conhecimento socialmente vigente. O importante para uma crítica social da fundamentação da razão não está, portanto, do lado das expectativas normativas que regulam efetivamente a produção e circulação de conhecimentos, mas sim do lado da relação que existe entre essas expectativas normativas e as condições nas quais elas devem necessariamente encontrar validez. Como a distância entre ambas as instâncias se ampliou significativamente com o modo de produção capitalista (por seus próprios requisitos econômicos, tecnológicos e políticos), existe a possibilidade de realizar uma crítica das formas de pensamento vigentes a partir de suas próprias pretensões de validez.

Tanto para Lukács quanto para Habermas - que aqui só explicitam a autocompreensão de si mesma da modernidade - o racionalismo moderno deu forma, em termos potenciais ou prático-ideais, a um tipo de pretensões de validez completamente original, pretensões que reiteradamente provocam uma discrepância trágica entre o saber e a certeza sobre esse saber. Pela primeira vez o conhecimento objetivo, isto é, o conhecimento que deve valer para todos, se vê enfrentado ao instável requisito de procurar "a coincidência de todos os juízos, apesar da diversidade dos sujeitos", dado que só a esse "fundamento comum no qual concordam todos os juízos" pode recorrer a pretensão de verdade do juízo racional, que já não reconhece em sua esfera de validez nenhuma autoridade particular (política ou religiosa). ${ }^{41}$ Esta verdade já não pode ser vista simplesmente como algo que deve estender-se a todos os homens, mas sim como algo que tem que surgir ativamente deles, pois "no que interessa a todos os homens sem distinção, não pode acusar-se à natureza de uma distribuição parcial dos dons, e, em relação aos fins essenciais da natureza humana, a filosofia mais elevada não pode ir mais longe do que a

\footnotetext{
${ }^{41}$ Kant, I., Kritik der Reinen Vernunft (B), pág 532.
} 
guia que também a natureza concedeu ao entendimento comum (gemeinste Verstand)" ${ }^{42}$. Este duplo sentido do novo sujeito de saber, que aparece como aquele que não é portador de nenhuma natureza especial e como aquele que é capaz de "coincidir com todos", dá uma idéia precisa do que a modernidade pretende que se cumpra para reconhecer algo como verdadeiro. $\mathrm{O}$ conceito de entendimento comum, que determina essa faculdade que pode encontrar-se em "qualquer homem" e que se realiza na confrontação e conciliação com "todos os homens", marca a novidade das pretensões de validez do racionalismo moderno e prefigura as dificuldades e os conflitos de seu dramático vínculo com a faticidade. Forma parte da crítica mais elementar à fundamentação moderna da racionalidade, a constatação de que "qualquer" e "todos" são apelações que se encontram, a partir de sua abstração e indeterminação, perigosamente próximas a "nenhum".

Mas a crítica a essa abstração e indeterminação parece vir sugerida - ao menos assim o entendem Habermas e Lukács - pela própria diferença entre aquilo que a racionalidade moderna deve propor como condições para a formulação de juízos verdadeiros e as regras e instituições que sancionam efetivamente o saber. Se a pouco de proclamar a universalidade da razão, esta deve advertir que existe uma "qualidade requerida para raciocinar" que determina ter direito a exercer o uso público da razão só quem for "senhor de si mesmo e tiver, portanto, alguma propriedade da qual viver" lugar adequado para a crítica da razão não deveria achar-se, entretanto, fora desta diferença e contradição. Pelo contrário, é ao interior da distância entre suas pretensões de validez e suas encarnações normativas que se pode criticar o caráter particular, passivo, interessado e violento do que deveria ser universal, ativo, desinteressado e não-violento. Para Habermas e Lukács, as pretensões de validez da racionalidade moderna desencadeiam necessariamente esta dialética interna, deixando para a teoria crítica a função de esclarecer suas causas (sociais) e ajudar a resolvê-las, reconstruindo para o conhecimento expectativas normativas "depuradas".

Resulta notório que o caminho que escolhem Lukács e Habermas para realizar essa função da teoria crítica é significativamente divergente. Não nos vamos deter aqui nessa

\footnotetext{
${ }^{42}$ Kant, I., Kritik der Reinen Vernunft (B), pág 538.

${ }^{43}$ Cfr., Kant, I., Werke, vol. VI, pp. 378 y ss.
} 
diferença. ${ }^{44}$ Assinalaremos simplesmente, em termos muito gerais, as dificuldades que essa posição pode encontrar. Por um lado, eles têm a necessidade de demonstrar que a racionalidade que se faz efetiva com o capitalismo depende ou produz necessariamente essas pretensões de validez universais com as quais entra em contradição. Como a crítica social de ambos, imanente às diferentes "estruturas de sentido" vigentes na modernidade, não se limita à mera contrastação dos efeitos produzidos na faticidade pelas regras do conhecimento racional mas, ao mesmo tempo, tenta confrontar essas regras e seus efeitos (de poder e destruição) com as pretensões de validez (não-violentas e pacificadoras) dessa mesma racionalidade, eles têm que demonstrar que este desdobramento não só é possível, mas também é necessário e determinante ao interior do modo de produção capitalista. Do contrário teriam que aceitar que as "condições idealizadas" do conhecimento racional não são mais que um episódio casual e paralelo da história européia, que não permitiria que essas pretensões de validez fossem reconstruídas a partir das operações normativas reais e que seus efeitos fossem amplamente reconhecidos como "patológicos". Quer dizer, eles têm que demonstrar que dentro do capitalismo a aparição de um horizonte de validez pacificador e universalista não é contingente, mas sim necessário. ${ }^{45}$ Por outro lado, esta posição deve demonstrar que as pretensões de validez racional não estão condenadas, no capitalismo, a uma completa impotência, já que do contrário se converteriam num puro mascaramento (ideológico) dos interesses que regulam efetivamente o saber. Sob este

\footnotetext{
${ }^{44}$ Temos analisado o modo radicalmente diferente de fazer a crítica ideológica da Razão por parte de Lukács e Habermas en: Ipar, E., "Georg Lukács y la cultura moderna”, in: Las aventuras del marxismo. Dialéctica e inmanencia en la crítica de la modernidad, ed. Gorla, Bs. As., 2003.

${ }^{45}$ Como temos sugerido previamente, sem poder estender-nos na matéria, tanto Lukács quanto Habermas supõem que determinadas exigências tecnológicas, econômicas e políticas do modo de produção capitalista não poderiam ser cumpridas sem um horizonte de sentido que tende "realmente" à universalidade das formas de compreender o mundo e à liberdade do sujeito que procura socialmente a verdade. Por exemplo, para o caso das exigências tecnológicas do capitalismo (a capacidade de controlar a natureza e administrar eficazmente as respostas às demandas que dimanam do interesse público), Habermas considera que estes nunca poderiam ser cumpridos sem uma diferenciação eficaz da ciência em relação às exigências funcionais da economia e da política, de maneira de poder pôr na prática condições para a produção e a circulação do conhecimento em que a capacidade para superar a própria perspectiva e a aceitação de "todas" as criticas possíveis de um argumento determinado, não sejam uma mera ficção. Isto não supõe, pelo menos para Habermas, o caráter metafísico daquelas condições idealizadoras da validez, mas, pelo contrário, pretende demonstrar que as mesmas podem ser encontradas nas práticas concretas nas quais a racionalidade na modernidade diferencia-se. Esta análise histórico-sociológica é a base da crítica habermasiana ao discurso filosófico da modernidade.
} 
aspecto, o problema que surge imediatamente é: como conservar a distinção entre faticidade e validez da verdade, sem traçar uma drástica separação idealizadora? Como reconstruir o horizonte de sentido que permite reconhecer as diferenças e contradições do processo de racionalização, sem cair nos impasses que enfrentou em seu momento o transcendentalismo da escola de Windelband e Rickert? No caso particular de Habermas pode-se afirmar, sem dúvidas, que ele prefere correr esse risco a suprimir a diferença entre validez e faticidade, e a terminar por afirmar que toda racionalidade é ideológica, e que, portanto, a distância reflexiva, a independência, a intersubjetividade livre, são só ficções a serviço do poder.

Entende-se agora porque para Habermas a distinção entre validez e faticidade transforma-se num tema crucial. Em sua interpretação dos dilemas culturais do capitalismo tardio, essa distinção resulta fundamental para estabelecer o caráter crítico da teoria crítica, dado que sem ela carecer-se-ia do critério normativo necessário para criticar a conformação do existente, a teoria tornando-se impotente. Sob esta perspectiva, uma vez que se suprime a análise diferenciadora dos caminhos da racionalização, a teoria carece completamente do critério que lhe permite individualizar aquelas contradições sobre as quais tem que descarregar a interpretação crítica da arquitetura da razão em chave de teoria da sociedade. A esta supressão teriam sucumbido - para Habermas - Adorno e Horkheimer quando radicalizaram a análise do fenômeno da coisificação e atribuíram a "toda" a racionalidade moderna o caráter de ideologia. Por que abandonaram - pergunta-se Habermas - a crítica da ideologia de orientação marxista, e radicalizaram a crítica à razão até levá-la aos fundamentos da racionalidade moderna, deixando em perigo à própria Razão? Sua resposta a esta pergunta esta contida no esboço de seu próprio programa de teoria social, que procura identificar, junto "com a propensão a uma regressão social da razão, uma nada desprezível coação: induzida pela racionalização das imagens do mundo e dos mundos da vida, que obriga a uma progressiva diferenciação de uma razão que imediatamente adota uma forma procedimental" 46 . Esta diferenciação compete "com a assimilação naturalista de pretensões de poder e pretensões de validez, com a destruição da capacidade crítica" e se “desenvolve nas culturas de especialistas, nas quais a interna articulação das distintas

\footnotetext{
${ }^{46}$ Habermas, J., (1989): 143.
} 
esferas de validez faz com que as pretensões de verdade proposicional, de retidão normativa e de autenticidade imponham seu próprio sentido específico" ${ }^{47}$. Para criticar a assimilação do "mundo da vida" intersubjetivo ao domínio da racionalidade instrumental, Habermas não concebe outro caminho que retornar à crítica imanente, que procura nas próprias formas de racionalidade vigentes "complexos de sentido" bloqueados e desarticulados, mas reais enquanto potencialidades de uma racionalidade diferente e socialmente construtível. Não importa se com isto termina retrocedendo em relação a Weber precisando reafirmar uma petição de universalidade quase-transcendental, ahistórica e trans-cultural.

Por outro lado, como a principal tendência ideológica do processo de racionalização é identificada com o apagamento e a repressão no plano do pensamento da diferença entre as esferas de validez racionais e a pura faticidade nomologicamente determinável, Habermas tem que incorporar - explícita e implicitamente - em sua crítica à Razão funcionalista todos os discursos filosóficos da modernidade que, para auscultar o caráter auto-destrutivo da razão, desprezam o alcance de seu desdobramento interno em esferas de validez e esferas institucionalizadas de expectativas normativas. Seu argumento é agora completamente inteligível: a crítica frontal e externa à racionalidade moderna reproduz, ao considerar como pura ideologia a suas pretensões de validez, a própria ideologia que quer combater, quer dizer, sanciona a vigência de um mundo que pode ser completamente explicado como um sistema auto-regulado de relações de força e tramas institucionais ritualizadas. Esta racionalidade funcionalista, que explica as expectativas normativas historicamente produzidas como o resultado de interesses e estratégias de poder, torna definitivamente inútil o caráter crítico de qualquer teoria da sociedade. Para enfrentar este resultado Habermas situa novamente à diferença entre validez e faticidade (e com ela as categorias de inter-subjetividade livre, interação, sentido interpretável, racionalidade procedimental) no lugar de paradigma de toda teoria crítica ${ }^{48}$.

\footnotetext{
${ }^{47}$ Ibíd. (grifos meus).

48 "Sólo cuando se han diferenciado las relaciones de sentido y las relaciones objetivas, sólo cuando las relaciones internas y las relaciones externas se han separado; sólo cuando la ciencia, la moral y el arte se ha especializado cada una en una pretensión de validez, siguen cada una su propia lógica interna y quedan apuradas de escorias cosmológicas, teológicas o cultuales; sólo entonces puede surgir la sospecha de que la autonomía de la validez que una teoría, sea empírica o normativa, reclama para sí, es pura apariencia
} 
Mas com esse movimento ele não só rejeita o "naturalismo" e o "vitalismo" neonietzscheano, senão que também considera inviável, ou diretamente ignora, a possibilidade de efetuar uma dupla abordagem, ao mesmo tempo externa e imanente, na crítica filosófica da Razão. Por momentos Habermas reconhece que não pode utilizar com Adorno e Horkheimer sua rígida distinção entre crítica totalizadora e crítica diferenciadora, porque eles teriam feito esforços permanentes para orientar-se no sentido desta última e só a partir de seu fracasso teriam sucumbido à primeira. Mas, por isso mesmo, não considera que nenhum caminho alternativo possa surgir dessa vacilação. O programa de Adorno, que se propõe, pelo contrário, estabelecer a partir da oscilação entre a crítica imanente e a crítica externa uma estratégia original de interpretação filosófica, é algo que Habermas considera inviável. Tentaremos mostrar mais adiante como nas análises filosóficas, estéticas e sociológicas Adorno nunca se pronunciou a favor de uma dissolução lógica ou ontológica da diferença entre validez e faticidade. Só se pode confundir com essa afirmação o tratamento, muito utilizado por Adorno, que consiste em fazer "como se" a coisificação fosse total, partindo da hipótese de que já não existiria nenhuma distância na sociedade entre as pretensões de validez da racionalidade vigente e sua violenta encarnação normativa. Esse procedimento permite-lhe explorar o funcionamento da Razão desde fora (isto é, sem aceitar seus princípios constitutivos), sem que saia daí nenhum juízo definitivo sobre sua "natureza". Mas pelo que lhe ditam os requisitos de sua própria "mudança de paradigma”, Habermas vê-se reiteradamente inclinado a rechaçar este tipo de olhar externo e despreza sua possível contribuição para a crítica imanente da Razão.

c) A frustração da crítica social ou de uma infrutífera estetização da teoria

Com o diagnóstico sombrio do capitalismo tardio e a perda de um horizonte filosófico que permitisse fundamentar em termos imanentes uma "nova norma de verdade", Adorno e Horkheimer viram-se conduzidos necessariamente - esta é a conclusão a que chega Habermas - a uma concepção essencialmente contraditória da condição humana, que

porque en sus poros se han introducido furtivamente intereses y pretensiones de poder no declarados." Habermas (1989): 145. 
oscila entre uma razão subjetiva, postulante de um princípio de autoconservação, o qual, porém, não pode neutralizar seu caráter autodestrutivo, e uma razão objetiva, postulante de uma unidade indiferenciada de espírito e natureza, a qual anula as transformações sócioculturais que tornam possíveis a moralidade e a verdade. Para Habermas, tanto Adorno como Horkheimer ficaram teoricamente "prisioneiros desta contradição", deixando severamente em risco a própria cientificidade dos seus argumentos, "dado que com as aporias de uma filosofia que nega a si mesma" ${ }^{, 49}$ não seria possível desenvolver um trabalho científico adequado. Uma vez que a racionalidade for colocada como o problema central das ciências sociais (e em especial da sociologia), não se podem evitar as repercussões dessa problemática acerca da instância de fundamentação da própria racionalidade das ciências sociais. E esta instância de fundamentação parece tornar-se impossível se for obrigada a carregar consigo um diagnóstico histórico que sublinha a universalização do domínio da racionalidade administrativa e, ao mesmo tempo, uma crítica das pretensões de validez das outras formas de racionalidade que as descobre funcionando integralmente como ideologia. O que Habermas se pergunta a partir da constatação deste duplo fechamento (sociológico e filosófico) da análise de Adorno e Horkheimer é se, no fim das contas, a crítica que descobre o reaparecimento do mito nas mais diversas produções do mundo não corre o risco de se tornar ela mesma uma nova, talvez a última, versão do pensamento mítico, que logo passa a ser projetada sobre uma realidade histórica imensamente mais complexa.

O estatuto de um pensamento crítico que não se sustenta em termos pragmáticos nos progressos do processo social de modernização e que não se confia absolutamente à potencialidade da crítica imanente da Razão converteu-se no século XX, sem dúvida, em um dos problemas filosóficos mais difíceis de abordar. O conjunto da interpretação de Habermas supõe que Adorno e Horkheimer, quando perderam a possibilidade de se vincular em termos positivos com a ciência e a filosofia moral de sua época, tiveram que ancorar os fundamentos de sua crítica - sem medir as consequências deste passo que estavam dando - no território da arte e na teoria estética. Por conta disto, a "racionalidade anterior à racionalidade" (que por princípio foi situada desde sua origem como razão

\footnotetext{
${ }^{49}$ Habermas, J., "Dialektik der Rationalisierung", in: Die Neue Unübersichtlichkeit. Kleine Politische Schriften $V$, Suhrkamp, Frankfurt am Main, 1985, p. 172.
} 
instrumental) só a puderam procurar, infrutiferamente, no conceito de mimesis. Deste conceito dependeria uma teoria da reconciliação universal e um horizonte normativo relativo à verdade, os quais se tornam, entretanto, completamente impraticáveis, já que para estes filósofos resultava impossível uma "teoria" da mimesis, entendida como uma teoria que pudesse dar conta racionalmente da unidade da identidade e da não-identidade entre o espírito e a natureza. Por esse caminho a Dialética da ilustração transformou-se em algo intrinsecamente paradoxal e afastado da possibilidade de fundamentar criticamente a teoria das ciências sociais.

Para Habermas, Adorno nunca quis "sair desta aporia", a qual ele reproduz na Dialética negativa com um discurso que enuncia ambas coisas ao mesmo tempo: a tentativa de circunscrever o que conceitualmente não se pode dizer e a advertência contra toda tentativa de recorrer a uma nova metafísica ou ontologia fundamental que pretenda resolver os problemas de sentido no "mundo administrado" a partir de um acesso imediato ao Ser. O que faz este tipo negativo de dialética é transpassar as competências do conhecimento à arte, pois na arte a faculdade mimética adquire forma objetiva e produz um conhecimento não-conceitual da história e da sociedade. Mas com isto - segundo a interpretação de Habermas - renuncia-se às pretensões mínimas de uma autêntica teoria. Para ele a Dialética negativa e a Teoria estética remetem-se impotentes uma à outra, revelando as consequências do abandono, realizado na Dialética da Ilustração, do processo de autoclarificação da razão por meio do pensamento discursivo. O ponto culminante desta fundamentação infrutífera que, por meio do conceito de mimesis, pretende apoiar-se nas potencialidades críticas da arte, aparece nas teses referidas à "rememoração da natureza oprimida" no sujeito, entendida esta como a última condição de possibilidade de uma crítica aos momentos ideológicos do processo de modernização. ${ }^{50}$ Com este tipo de fundamentação do pensamento crítico, produzir-se-ia um "abandono definitivo da cientificidade" como critério que deve ser estabelecido pela teoria crítica ao interior de suas investigações, tanto em termos normativos como em termos empíricos. A rememoração da natureza oprimida (pela universalização do domínio da racionalidade administrativa e pelo caráter ideológico que assumem as pretensões de validez das outras

\footnotetext{
${ }^{50}$ Cfr., Habermas (1987a): 492.
} 
esferas da racionalidade) só pode fazer-se por intermédio de um meio expressivo que não reclame para si a universalidade do conceito e não possa ser posto a serviço do controle das coisas. Mas quando a arte é forçada a cumprir esse papel de substituir o conceito, longe de prover efetivamente as ciências sociais de um paradigma adequado para a crítica do "mundo administrado", o mais provável é que ela mesma termine padecendo uma regressão a seu estatuto mitológico. Naquela direção dirige-se - para Habermas - a remissão recíproca da Dialética negativa com a Teoria estética de Adorno.

A partir do que acabamos de dizer, devemos destacar de que modo, para Habermas, a correta delimitação entre mito e razão não faz simplesmente parte de um problema de história ou antropologia cultural, mas também define as condições de possibilidade das ciências sociais no capitalismo tardio. Como vimos anteriormente, a tendência intrínseca da racionalidade administrativa, em termos de domínio social, consiste numa progressiva neutralização da autonomia do sujeito, da sociedade e da cultura. Essa neutralização, que parte tanto da empresa capitalista como do Estado moderno que resulta adequado para o normal desenvolvimento daquela, põe em risco a distância reflexiva que podem assumir os sujeitos e os grupos sociais com respeito às diversas ordens de expectativas normativas regentes nessas sociedades, ameaçando-as com um retorno a um tipo de legitimidade da ordem social na qual as pretensões de validez que se fazem efetivas são as do mito. Mas, por isso mesmo, se o momento kafkiano da teoria da racionalização weberiana denunciava a racionalidade administrativa como o "modelo da servidão do futuro", o que precisa ser feito em esse contexto é considerar a expansão dessa forma de racionalidade como a matriz de uma nova mitologia, e não considerar o mito como uma instância capaz de encarnar adequadamente a crítica frente ao domínio da racionalidade. Todo discurso filosófico da modernidade constrói-se, para Habermas, a partir desta confusão, quer dizer, a partir da incapacidade de conhecer as exigências autênticas do pensamento crítico frente à encruzilhada do capitalismo tardio. Nessa incapacidade teria caído tanto a Dialética negativa como a Teoria estética, fundamentalmente quando atribuem à arte e ao comportamento mimético um papel de protagonista.

O tópico fundamental que Habermas utiliza em sua obra para pensar a diferença entre o pensamento mítico e o pensamento racional deve ser achado na categoria de "descentramento". Tanto em termos histórico-culturais como em termos de psicologia 
genética, o que resulta decisivo para estabelecer as condições de possibilidade da racionalidade é a progressiva dissolução das diversas formas de autocentramento do sujeito e da cultura. ${ }^{51}$ Recordemos que para Habermas o mito caracteriza-se por operar a partir de uma "força totalizadora", na qual "todos os fenômenos observados na superfície são ordenados em uma rede de correspondências, de relações de semelhança e de contraste", graças à vigência de "conceitos básicos" que reúnem categorialmente aquilo que a “compreensão moderna do mundo não tem mais remédio que não o de separar" (Habermas, 1989: 144). Deste modo, a linguagem, por exemplo, não aparece no mito ainda tão diferenciada da realidade como acontece na compreensão racional do mundo, dado que ali "o signo convencional ainda não se pode separar por completo do conteúdo semântico e do referente", pelo qual "a imagem linguística do mundo permanece entretecida com a ordem do mundo" (Ibid.). É por isso que "as tradições míticas não se podem revisar sem pôr em perigo a ordem das coisas e a identidade da tribo, que se funda nessa ordem", já que no interior do mito as categorias de validez como "verdadeiro" e "falso, "bom" e "mau", formam ainda "uma unidade com conceitos empíricos como troca, casualidade, saúde, substância e capacidade" (Ibid.). Esta particular combinação desencadeia-se basicamente porque o pensamento mágico "não permite nenhuma distinção categorial entre coisas e pessoas, entre o inanimado e o animado, entre objetos que podem manipular-se e agentes aos que imputamos ações e manifestações linguísticas" (Ibid.). Logo, se toda desmitologização consiste em dissolver este "encantamento que para nós, modernos, não tem outro remédio senão aparecer como uma confusão entre natureza e cultura" (Ibid.), dever-se-á concordar com Habermas sobre o fato de que "a ilustração conduz a uma dessocialização da natureza e a uma desnaturalização do mundo humano" (Ibid.) que só pode ser compreendida como um progressivo descentramento das imagens do mundo que organizam a cultura e a identidade do sujeito.

Claro que esse descentramento da Ilustração pode ver-se interrompido e podem ocorrer movimentos regressivos, tanto no nível da cultura quanto do sujeito. Weber, Adorno e Horkheimer mostraram como a racionalidade conforme fins e a racionalidade administrativa encarnam, para a cultura e para o sujeito, exemplos notáveis deste tipo de

\footnotetext{
${ }^{51}$ Ver especialmente: "Algunas características de la comprensión mítica y de la comprensión moderna del mundo", in: Habermas, J., (1987a): 69-110.
} 
regressão. O que não puderam fazer foi reencontrar o limite desses transbordamentos patológicos e o caminho de uma cultura diversificada e diferenciada, no interior das próprias pretensões de validez do racionalismo moderno. Pelo contrário, Adorno e Horkheimer vão procurar na experiência estética a possibilidade de continuar o "caminho da ilustração por outros meios". Mas com isto desconhecem - segundo Habermas - a enorme proximidade que existe entre a radicalização da modernidade na esfera da arte e a dissolução mitológica da diferença entre natureza e cultura, que era o que precisamente queriam desmantelar no império da racionalidade administrativa. ${ }^{52}$

O tipo de descentramento que levam a cabo as vanguardas artísticas do século XX, o qual depende por sua vez de uma "subjetividade descentrada, liberada de todas as limitações do conhecimento e da atividade racional conforme fins, de todos os imperativos do trabalho e da utilidade" (Habermas, 1989: 153), promove um tipo de "rebelião contra todo o normativo" (Ibid.), que termina estreitando a distância entre a faticidade e a esfera de validez, do modo como o faziam as antigas representações mitológicas. O que significa que no momento em que a arte radical reclama seu tipo particular de influência sobre a vida social, seu momento de soberania, esta só pode realizar-se às costas da distância reflexiva e da diferenciação que permite a determinação racional da verdade do conhecimento e a retidão das normas morais.

A soberania da arte que proclamam as vanguardas não se poderia realizar sem uma substantiva interferência nas esferas de validez da moral e do conhecimento, dado que essas vanguardas alcançam seus efeitos especificamente estéticos logo quando conseguem "fundir" em relações de semelhança e contraste aquilo que "a compreensão moderna do mundo" precisa diferenciar; quando procedem por meio da "anulação" do corte que existe entre os signos convencionais, seu conteúdo semântico e seu referente; quando deixam fora de ação categorias como "bom" e "mau", "verdadeiro" e "falso", ao confundir seu uso com as de "bem-estar", "substância" e "potência"; e quando enfim não admitem nenhuma distinção categorial entre as coisas e as pessoas, entre o inanimado e o animado, entre os objetos que podemos manipular e os agentes aos quais imputamos ações e manifestações linguísticas. Este tipo de soberania da arte aparece na análise de Habermas tão motivado

\footnotetext{
${ }^{52}$ Cfr., Habermas, J., (1989): 160-162.
} 
por uma vocação "colonizadora" quanto a soberania que exerce tendencialmente o império da racionalidade administrativa. Sob esta perspectiva, a arte radical não poderia servir em nenhum caso como modelo para a teoria crítica, já que só pode opor-se ao modo violento com que se realiza a desmitologização do mundo por meio de uma nova mitologia. O tipo particular de descentramento que efetua a arte radical é visto, na sua realidade social, como uma enorme operação de recentramento, do sujeito e da cultura, em torno de pretensões de soberania e de autotransparência da vida pulsional, as quais normalmente terminam transformando-se em desespero niilista e ceticismo radical. Só quando essas pretensões "vitalistas" passaram através da mediação e do reconhecimento da validez das outras esferas (ciência, moral), quer dizer, quando essas pretensões foram racionalizadas, pode então entrar a arte como momento do pensamento crítico $n a$ modernidade, o que não a habilita a aspirar ocupar o lugar de fundamento da racionalidade da teoria crítica. Este foi o grande erro no qual teria caído Adorno em sua procura de uma "racionalidade anterior à racionalidade" por meio da fundamentação recíproca proposta por ele entre a Dialética Negativa e a Teoria Estética. Ao exigir à arte um conhecimento da sociedade e da história que fosse capaz de incidir criticamente sobre o domínio da "racionalização administrativa" do mundo, Adorno foi forçado a retomar o projeto enfático de soberania da arte moderna, o qual ironicamente implicava em si mesmo um tipo de anulação da esfera de validez do conceito, inutilizando-o para o campo da teoria que o próprio Adorno estava procurando construir.

Com a ideia de mimesis, Adorno e Horkheimer procuraram reconstruir, para a teoria crítica do conhecimento, um modelo de unidade não-violenta da identidade e da diferença que servisse para substituir o conceito, cujo conteúdo tinha-se demonstrado historicamente falso. O comportamento mimético podia servir de fio condutor para uma fundamentação da verdade que não funcionasse como uma máscara ideológica da vontade de domínio sobre a diferença que se torna predominante no capitalismo tardio, isto é, que tivesse uma estrutura interna diferente daquela da racionalidade instrumental no nível do sujeito e da racionalidade administrativa no nível da cultura. Mas a realização desta ideia só teria conduzido Adorno a afirmar um tipo de mediação entre arte radical e filosofia na qual o que se ganha frente à razão instrumental perde-se em relação à teoria da verdade e da justiça. Ocorria uma encruzilhada na qual a mimesis, o outro do conceito que funciona somente 
como um mero instrumento de domínio, transformava-se, também ele, numa pretensão de soberania sobre a sociedade e a história, o que tornava impossível a crítica desideologizadora do conhecimento e da moral. Como esforço para estabelecer uma mediação entre a arte e a filosofia, a mimesis revelava-se como a última versão de uma mitologia desdiferenciadora. Habermas situa neste contexto os impasses teóricos de Adorno e Horkheimer, e se vê obrigado a uma completa "mudança de paradigma" para superar o conjunto de limitações que faziam impossível a realização do projeto de alcançar uma fundamentação crítica das ciências sociais. Segundo ele, só retrocedendo no caminho da crítica radical, ou seja, reencontrando nas pretensões de validez do racionalismo moderno os esboços de uma racionalidade não-mutilada, esse projeto podia começar com alguma perspectiva de êxito.

Claro que frente a esta interpretação totalizadora encontramos novamente algo que já havíamos sugerido. A interpretação de Habermas não só é - como não poderia ser de outro modo - parcial e está previamente orientada por seu novo paradigma da ação comunicativa; ela também silencia estrategicamente um detalhe que poderia ter suscitado outra série de condições para analisar o que estava em jogo nesta discussão. O principal detalhe que oculta neste caso Habermas, quando se refere à "estetização da teoria" adorniana, é o fato de que para Adorno a soberania da arte só pode ser pensada a partir da sua autonomia. $\mathrm{Na}$ interpretação de Adorno a arte só se transforma em uma práxis soberana, isto é, ativamente capaz de interferir nas outras esferas sociais, quando se transforma, simultaneamente, em uma práxis autônoma. Portanto, não existe nenhuma questão de princípio que vincule, em termos que resultam adequados para uma teoria da sociedade, a soberania da arte a uma vocação de "colonizar" e suprimir a lógica específica do conceito e do conhecimento moral. A Dialética Negativa tenta oferecer distintos modelos de categorias que permitem pensar um tipo de mediação entre a arte e a filosofia, entre a experiência estética e o conceito, que, sem implicar a redução de um deles a outro, pode opor-se à coisificação administrada da razão filosófica e sociológica a partir de um ponto de vista que resulta impossível para a sua autocompreensão puramente teórica, ou seja: a experiência corporal do sofrimento, os silêncios da opressão, as histórias sem textos, quer dizer, tudo isso que Adorno chamou em Minima Moralia "a vida danificada". Esta mediação não suprime a fundamentação conceitual da teoria crítica da sociedade, mas a 
enfrenta com uma série de problemas que caem "naturalmente" fora de seu campo de interesse. Como vimos em nossa reconstrução, em relação a esta possível ampliação ou prolongação da instância de fundamentação da teoria crítica da sociedade, Habermas não oferece nenhum tratamento detalhado. 


\section{Capítulo 2: Em busca da política perdida \\ A filosofia política hegeliana na era do Estado Social}

Take up the bodies, such a sight as this becomes the battlefield, but here shows much amiss.

Fortinbras (Hamlet, A. 5, S. 2)

Em seus primeiros escritos, Axel Honneth elabora um balanço teórico de Adorno e Horkheimer que concretiza e expande a colocação de Habermas. Além das pequenas diferenças que os separam no interior desta polêmica, pode-se afirmar que o enfoque geral destes textos de batalha complementa as posições teóricas mais sistemáticas de Habermas. Se a crítica de Habermas, como vimos, se desenvolve a partir do problema da racionalização das práticas sociais na modernidade, a crítica de Honneth vai tomar como ponto de partida de sua controvérsia o estatuto da política no mundo contemporâneo e sua relação com a teoria crítica. Ambos coincidem em destacar as insuficiências teóricas do paradigma esboçado na Dialética da Ilustração, mas enquanto Habermas descobre essas insuficiências na inconseqüente crítica imanente das pretensões de validez do racionalismo moderno, Honneth põe o acento em sua falta de articulação com os movimentos, as lutas e os conflitos sociais de sua época. A complementaridade de ambas as críticas aparece a simples vista. Por um lado, Adorno e Horkheimer são enfrentados com uma crítica "desde acima": se tenta demonstrar que sua teoria não pode relacionar-se com os critérios de validez científicos e filosóficos que regem na modernidade cultural. Por outro lado, argumenta-se, agora "desde abaixo", que essa mesma teoria tampouco pode interagir criativamente com o contexto político do qual forma parte, contribuindo com formas de interpretar a situação histórica e de reinscrever os resultados de suas investigações nos conflitos sociais que lhe dão forma a seu presente.

Se exagerássemos o que queremos expressar, diríamos que o que Honneth procura com esta crítica não é uma recuperação do Marx científico, quer dizer, do estatuto filosófico da racionalidade de sua teoria, mas uma reatualização do momento político do marxismo, para o qual tenta dar forma a algo que poderíamos chamar " $O$ Dezoito Brumário" da teoria crítica frankfurtiana. A pequena diferença consiste, é claro, no fato de 
que na era do "Estado Social" e do capitalismo global os instrumentos desta reparação teórica já não seguirão a linguagem da tragédia e os imperativos do hic Rhodus, hic salta da política, mas surgirão do pragmatismo psico-social de George Mead e da filosofia do Estado de Hegel. Com eles, Honneth indagará as insuficiências sociológicas da "Idéia originária de Horkheimer" e o modo pelo qual a "filosofia da história de Adorno" cancelaria qualquer conexão com a política. Sua própria teoria do reconhecimento aparece, sobre esse fundo, como a filosofia anelada que teria de permitir à escola de Frankfurt, finalmente, contar com as categorias adequadas para "pensar a política". Não vamos nos deter senão tangencialmente nos méritos e déficits desta teoria. $\mathrm{O}$ que nos interessa na colocação de Honneth é, por assim dizer, aquele conteúdo que - segundo ele - sua teoria do reconhecimento superaria, isto é, as implicâncias sociológicas e políticas do pensamento de Adorno e Horkheimer.

Como se sabe, a maioria dos textos políticos de Marx, ao menos aqueles que Marx "conseguiu escrever", situam a luta de classes no centro da cena política. De seu devir depende a trama secreta do processo político que, de outro modo, se se carecer dessa chave de leitura, apareceria como uma pura sucessão lógica de formas de governo, como a realização espiritual das Idéias morais ou como a mera luta estratégica para tomar e conservar o poder levada a cabo pelas mais diversas personagens históricas. Ao introduzir na superfície da política a questão das classes sociais, Marx realiza uma dupla operação teórica.

Por um lado, Marx destitui a cena política (o Estado) de seu caráter auto-suficiente no que diz respeito à capacidade de produzir e reproduzir a ordem social. Neste sentido, o poder político se torna impensável sem a precedência - pelo menos lógica - de um poder social, relativamente autônomo e diferente em relação ao modo como se apresenta a si mesmo o poder político (monopólio da violência legítima). No capitalismo, esse poder social se exerce através da apropriação e do controle dos meios de produção, no contexto do que o Marx maduro chamou relações sociais de produção. Essas relações sociais de produção são as que distribuem hierarquicamente (em termos de autoridade/subordinação) à população numa determinada posição do processo de produção, atribuindo-a diferencialmente (através de meios jurídicos - propriedade dos meios de produção - e nãojurídicos - possessão do trabalho e dos meios de produção -, que surgem da esfera dos 
"acordos privados" entre os "homens") capacidades, restrições e imperativos. O poder social que sanciona estas disposições e hierarquias pode perfeitamente ser reforçado e achar-se, em sua própria constituição, formalmente de acordo com o poder político, mas se perderia por completo a determinação marxiana do conceito se aquele fosse identificado ou subsumido a este último. O poder social, que dá forma à dominação de classe, atua com meios próprios, em circuitos específicos, que não são redutíveis ao poder político-estatal, sendo também sua finalidade particular (a extração de mais-valia e a valorização do capital) diferente à deste (a obediência). ${ }^{53}$

A segunda operação que realiza Marx em seus textos políticos consiste em tentar interpretar os conflitos que "aparecem" como manifestamente políticos como conflitos motivados pelos interesses invisíveis das classes que se enfrentam nas relações sociais de produção em termos de explorados e exploradores. Nesta segunda operação, do que se trata é de vincular a esfera "pública" da vida social à esfera "oculta" dos interesses de classe e as formas de domínio social não reconhecidas politicamente. Como o modo de produção capitalista pressupõe um tipo de separação entre o espaço das relações de produção, que garantem a reprodução material da sociedade por meio da intervenção sobre a natureza, e o espaço das relações políticas, que fornecem a possibilidade da deliberação sobre os interesses gerais e a potestade para sancionar as leis reguladoras da vida comum, nesse modo de produção aparece "naturalmente" a esfera político-estatal como o espaço precedente e determinante de todas as relações conscientes dos homens entre si e de toda a estrutura normativa de suas interações (incluídas as relações jurídico-econômicas). E é precisamente esta falsa aparência-necessária, que mostra invertida a ordem de precedência real das relações sociais de produção a respeito da esfera político-estatal, aquela que Marx conceberá como causa da "fantasmagoria"54 do mundo político na modernidade. Frente à

\footnotetext{
53 Para reconstruir la posición de Marx referida a la relación economía-política utilizamos deliberadamente una terminología lo suficientemente abstracta y sumaria como para no vernos obligados a tomar una posición, en este lugar, sobre la extendida discusión que generó dentro del marxismo esta cuestión entre las interpretaciones instrumentalistas (Miliband), estructuralistas (Poulantzas) o derivacionistas (Hirsch) del lugar y la naturaleza del Estado en el capitalismo. Para el desarrollo de nuestra argumentación posterior tendremos ocasión de volver sobre este tema.

54 Para uma interpretação desta categoria de fantasmagoria política no pensamento frankfurtiano ver: Matos, O., Os arcanos do inteiramente outro, ed. Brasiliense, São Paulo, 1989 (especialmente cap. 1: “Uma historia barroca").
} 
materialidade dessa fantasmagoria, que faz com que os homens assumam "roupagens" anacrônicas em relação a seus interesses e que recorram a linguagens "emprestadas" para interpretar seu próprio protagonismo, são apresentadas à teoria crítica uma série de perguntas inescapáveis: O que fazer? Como interpretar o sentido profundo dos conflitos sociais na superfície caricatural dos conflitos políticos $?^{55}$ Em definitivo, frente à reprodução da dominação e da exploração: como vincular-se com os interesses de justiça e emancipação das classes oprimidas no "theatrum mundi" da esfera pública burguesa?

Para Honneth, os imperativos desta crucial pergunta da política, surgidos num contexto brumoso na modernidade, são os que Adorno e Horkheimer não puderam interpretar adequadamente. Deste modo, assim como não puderam reconduzir o

${ }^{55}$ En un bello texto Jacques Derrida ha reinterpretado el legado de Marx en la senda de aquello que esta pregunta por el "desajuste" o por la "inadecuación" (entre los protagonistas y los personajes, entre el lenguaje y los discursos) abre para el pensamiento político. El espacio de la fantasmagoría política no haría posible, bajo esta perspectiva, una respuesta única en el caso de Marx. Derrida reinscribe a Marx en una oscilación que va desde la puesta en funcionamiento de una "metafísica de lo social", que tiende a silenciar el llamado de esas apariciones espectrales a partir de la intelección de los "verdaderos intereses" materiales de las clases sociales en pugna, a la asunción de una irrevocable "tragedia de la representación", que debe esforzarse por interpretar la demanda de justicia y reparación histórica que encarnan los "espectros" en la escena política sin la garantía de contar a priori con el lenguaje adecuado para ello. El sentido del propio texto de Marx sería portador -para Derrida- de esta disyuntiva en nuestro presente: "Si la legibilidad de un legado fuera dada, natural, transparente, unívoca, si no apelara y al mismo tiempo desafiara a la interpretación, aquél nunca podría ser heredado. Se estaría afectado por él como una cosa natural -natural o genética-. Se hereda siempre de un secreto -que dice: "Léeme. ¿Serás capaz de ello?»-." Derrida, J., Espectros de Marx, ed. Trotta, Madrid, 1995, pág. 30. El punto nodal de este "llamado", de este "asedio" que Marx revela como constitutivo de la escena política, y que es el que impide que ésta pueda ser pensada como auto-suficiente, puesto que no puede terminar de rechazar una presencia que proviene de afuera, que no es ni un producto ni un elemento de su funcionamiento auto-regulado como subsistema de la reproducción social, Derrida lo construye en torno a la famosa constatación trágica de Hamlet: "The time is out of joint", en cuya equivocidad (en sus diversas traducciones: "el tiempo está fuera de quicio", "el tiempo está trastornado", "el mundo está al revés", "esta época está deshonrada") ya aparece un indicio de la "tragedia de la representación" que él desea proponer como condición de la interpretación política y de la posibilidad de heredar el potencial emancipatorio de un pensamiento. Cfr., Derrida, J., op. cit., pp. 32 y ss. La posibilidad de interpretar este problema que suscita el desajuste que se hace manifiesto en la vida política a partir de una reactualización de la reflexión filosófica sobre el género trágico (que está en las antípodas, por cierto, al camino escogido por Honneth para pensar esta cuestión, al menos en sus primeros textos) ha recobrado recientemente la atención de la filosofía política, la ética y la estética. Me permito destacar aquí dos trabajos: Rinesi, E., Política y tragedia. Hamlet, entre Hobbes y Maquiavelo, ed. Colihue, Bs. As., 2003; y Menke, Ch., Die Gegenwart der Tragödie. Versuch über Urteil und Spiel, Suhrkamp, Frankfurt am Main, 2005. 
pensamento enredado pela fantasmagoria mercantil para uma "racionalidade não minguada", tampouco puderam repensar a lógica das lutas sociais e suas pretensões de reconhecimento no interior da fantasmagoria política do Estado capitalista. Para interpretar os momentos de desajuste na reprodução social, os pontos de desacordo entre seus membros, faltou-lhes prosseguir o horizonte de suas críticas à dominação capitalista no sentido de uma teoria social (de "teor normativo") da política ou uma "gramática moral dos conflitos sociais". As causas profundas deste déficit serão descobertas por Honneth no suposto recurso, de parte de Adorno e Horkheimer, a uma teoria funcionalista da sociedade, que dependeria por sua vez de uma concepção unilateral do poder (a). Este marco teórico os teria conduzido, irreversivelmente, a não poder atravessar a opacidade do social no capitalismo tardio, no sentido de elucidar os conflitos de poder e os movimentos de resistência que o constituem (b).

\section{a) O interesse da crítica e o fantasma do Estado-total}

Em seu livro Kritik der Macht, ${ }^{56}$ Axel Honneth repassou em detalhe os motivos do fracasso do legado teórico de Adorno e Horkheimer, fundamentalmente no que se referia a sua dificuldade para vincular-se com a (sociologia) política. Sua apresentação começa pela reconstrução do projeto originário de Horkheimer, que pretendia distinguir o campo da teoria crítica do campo da teoria tradicional a partir da relação diferenciada que ambas mantinham com os interesses da vida prática: "O objetivo de Horkheimer consistia em expor os caminhos práticos da concepção moderna da ciência para poder fundamentar a teoria crítica, entendida como a expressão autoconsciente do processo político e social de emancipação, no contexto prático que se tornou visível" (Honneth, 1997: 5). A partir da própria aceleração da modernidade, o contexto ao que faz referência Horkheimer é o da destituição das pretensões de neutralidade e objetividade absoluta da teoria tradicional, que já não pode negar que todo saber teórico encarna-se em práticas e produz efeitos sociais, por um lado, e que provém, por outro lado, de necessidades e interesses particulares, enquadrados em tradições culturais.

\footnotetext{
${ }^{56}$ Utilizamos a tradução ao inglês: Critique of Power, Honneth (1997).
} 
Uma vez que se tornou visível que não é possível nem um conhecimento desmotivado, nem um conhecimento que possa assumir uma posição asséptica frente à realidade, o que se torna imperativo para a teoria crítica é - dado que ela pretende evitar também o relativismo filosófico - a determinação, da forma mais clara e precisa possível, dos interesses pela "emancipação política e social" que existem em um contexto histórico particular. Esse processo de determinação de interesses se completa e se realiza como um processo de "autoconsciência" das potencialidades do presente, do qual a teoria crítica teria que ser um agente ativo.

Esta apresentação feita por Honneth, que pode parecer algo simplificadora e carregada com uma cota não desprezível de ingenuidade, tem o mérito de explicitar os requisitos mínimos de uma teoria da sociedade que pretenda ser algo mais (e algo oposto) a uma mera teoria descritiva ou explicativa da reprodução social. A necessidade desta perspectiva apoiada no interesse pela emancipação ainda se deixa ouvir com contundência em Adorno, no final de Mínima Moralia: "O único modo que ainda tem a filosofia de responsabilizar-se de cara ao desespero seria a tentativa de considerar as coisas tal como aparecem da perspectiva da redenção (wie sie vom Standpunkt der Erlösung aus sich darstellten). O conhecimento não tem outra luz iluminadora do mundo que a que lança a idéia de redenção: todo o resto se esgota em reconstruções e se reduz a mera técnica" (alles andere erschöpft sich in der Nachkonstruktion und bleibt ein Stück Technik, MM: 281).

Para cobrir os requisitos deste desafio teórico, Horkheimer utilizou - segundo reconstrói Honneth ${ }^{57}$ seu modo de relacionar conhecimento e interesse - algumas das teses com as que Marx tinha pensado a história, fundamentalmente o modelo que atribui o papel de motor do processo histórico à contradição entre o desenvolvimento das forças produtivas e as relações sociais de produção. É claro que Horkheimer não interpreta este modelo em chave tecnocrática (como fazia, nesse momento, o estalinismo), mas em chave éticocognitiva, ao incluir dentro da categoria de forças produtivas tanto o potencial em matéria de satisfação das necessidades desenvolvido pelo conhecimento científico, quanto a potência crítica da consciência de classe do proletariado. A partir desta definição, "as forças produtivas são vistas como um potencial emancipatório e sua organização não racional no

57 Honneth refere-se principalmente ao trabalho inaugural de Horkheimer: Traditionelle und kritische Theorie do ano 1937. 
capitalismo é considerada como expressão do auto-engano da humanidade" (Honneth, 1997: 9). O conhecimento social crítico seria aquele capaz de destacar e antecipar racionalmente a potencialidade evolutiva bloqueada ou desviada pela coação da forma de organização das relações sociais de produção vigentes.

Este tipo de conhecimento crítico poderia justificar-se a si mesmo como uma radicalização e abertura do próprio desenvolvimento do conhecimento científico na modernidade. Entretanto, a pouco de percorrer seus primeiros passos, vê-se que essa justificação leva dentro uma contradição que vai se transformar numa dificuldade real, tanto para elaborar uma distinção precisa com respeito à teoria tradicional, quanto para motivar a "decisão racional" da práxis orientada à superação da forma atual de organização das relações sociais de produção. O sintoma desta contradição se faz visível no fato de que o tipo de conexão com a prática que existe no conhecimento científico (quer dizer, o tipo de relação que a ciência mantém com as necessidades humanas das quais procede em termos antropológicos e com as práticas sociais às quais se dirige como saber que aperfeiçoa o controle da natureza e favorece a produtividade do trabalho) não implica nem desencadeia, por si mesmo, uma anulação do auto-engano dos homens sobre suas potencialidades bloqueadas pela estruturação da sociedade. A determinação racional do potencial contido no desenvolvimento da ciência para controlar a natureza não resulta suficiente para determinar a existência de um interesse pela emancipação, do qual a teoria crítica da sociedade seria uma "expressão", e que serviria para justificar sua diferença em relação à teoria tradicional. ${ }^{58}$ No mesmo sentido, a determinação das necessidades que poderiam ser satisfeitas a partir do conhecimento científico já adquirido tampouco resulta suficiente para motivar uma atividade crítica com respeito à estrutura social vigente. Honneth localiza a causa deste hiato no erro (do qual teria sido vítima Horkheimer por sua releitura do "evolucionismo naturalista" presente em alguns textos de Marx - e sobre tudo de Engels) que consiste em (com)fundir numa mesma categoria ao interesse pela emancipação das constrições naturais, com o interesse pela emancipação da dominação social.

Em seus textos dos anos 30', Horkheimer percebia com claridade que a teoria crítica devia tentar vincular a forma de seu conhecimento a um interesse diferente daquele que

\footnotetext{
${ }^{58}$ Cfr., Honneth (1997): 11-13.
} 
tende "a melhorar o funcionamento de qualquer elemento existente na estrutura social", dado que a atividade principal à qual a teoria crítica tinha que emprestar atenção era aquela que "tem por objeto a própria sociedade", não se interessando simplesmente em "eliminar este ou aquele abuso, mas procurando considerar esses abusos como necessariamente conectados com a maneira na qual a estrutura social está organizada" ${ }^{59}$ Entretanto, essa “atividade crítica" pré-científica, que toma "por objeto a própria sociedade", nunca pôde ser sistematicamente diferenciada da atividade do "trabalho social" que enfrenta a natureza, para constituir-se no interesse específico com o qual a teoria crítica devia entrar em diálogo na busca de sua própria fundamentação. ${ }^{60} \mathrm{O}$ conteúdo desta diferenciação, "que faz referência direta a uma dimensão de luta social, não tinha nenhum lugar sistemático no marco da filosofia da história que servia de pressuposto a Horkheimer: enquanto este marco teórico reduz o curso da história humana ao desenvolvimento quase-natural do processo de dominação da natureza, não existe a possibilidade conceitual de um tipo diferente de práxis

${ }^{59}$ Horkheimer, M., "Traditional and Critical Theory", in: Critical Theory, pp. 206-207. Citado en Honneth (1997): 12.

${ }^{60}$ Para Honneth, esta incapacidad para investigar según una perspectiva específica la dimensión de la sociedad en la cual lo que aparece es la capacidad de los hombres para tomar, por su propia cuenta, "a la sociedad como el objeto de su actividad", iba a repercutir negativamente en el intento por diferenciar en términos metodológicos a la teoría crítica de la teoría tradicional. Horkheimer entendía que una de las diferencias básicas entre ambas posiciones teóricas consistía en que, mientras la teoría tradicional tomaba a su objeto como una "cosa externa" que debía ser subsumida en una serie de categorías y un sistema de leyes enunciadas por un observador imparcial, para la teoría crítica resultaba fundamental alcanzar un conocimiento inmanente a los intereses y las perspectivas de los protagonistas, que no reprodujese en el ámbito de la teoría de la sociedad la lógica del saber que se orienta hacia el dominio y la manipulación de su objeto. Para Honneth este requisito epistemológico, anticipa lo que posteriormente se conocería como "doble hermenéutica" de las ciencias sociales, para la cual el objeto que ha de ser interpretado aparece al mismo tiempo como un objeto que es capaz de auto-tematizarse y auto-interpretarse. Esta perspectiva epistemológica se insinúa en los primeros textos de Horkheimer, pero indefectiblemente queda anulada por el uso que él hace de la filosofía de la historia. Bajo la mirada de esta observación crítica que efectúa Honneth, el problema radicaría en el hecho de que al enmarcar el proceso social en un proceso histórico, que es explicado a su vez siguiendo los lineamientos de una filosofía de la historia, se pierde necesariamente de vista la perspectiva del sujeto que interpreta su contexto social y que es capaz de actuar reflexivamente sobre el mismo. Por la propia lógica de toda filosofía de la historia, que parte siempre de acontecimientos ya sucedidos y sentidos ya interpretados, las proposiciones que surjan de su uso como matriz teórica van a tender a negligenciar la capacidad de producir acontecimientos e interpretar el sentido de los propios protagonistas. De este modo, al darle primacía a la filosofía de la historia Horkheimer habría terminado traicionando sus propios postulados epistemológicos. 
social que não tenha por objetivo a expansão produtiva da auto-conservação, senão um novo modo de organização social da auto-preservação" (Honneth, 1997: 13). Quando tentou vincular a teoria crítica com a "experiência social da classe oprimida" a partir de uma filosofia da história de inspiração marxista, Horkheimer viu-se obrigado a omitir completamente "a dimensão da crítica da vida cotidiana na qual a teoria deveria situar-se, enquanto essa teoria participa da forma cooperativa de interpretação do presente no sentido do interesse por alcançar uma superação das injustiças sofridas" (Ibid., 17). Neste ponto, o diagnóstico de Honneth é concludente: na procura de uma matriz teórica, existe no primeiro Horkheimer uma tensão entre uma teoria das lutas sociais e uma filosofia da história da emancipação do homem, que acaba se resolvendo completamente a favor desta última. A consequiência imediata desta posição central que assume a filosofia da história, da qual passa a depender o trabalho de articulação das investigações particulares, é a anulação da possibilidade de sustentar um vínculo autônomo com os conflitos sociais do presente e a inibição da produção de categorias adequadas a sua particularidade.

Evidentemente, em seus textos dos anos 30', Horkheimer percebe a especificidade das lutas sociais. Mas para promover sua interpretação, a primeira formulação de sua teoria subsume o interesse pela emancipação social, que se exprime nessas lutas sociais, à lógica do interesse pela emancipação das constrições naturais. Esta subordinação teórica supõe que o interesse pela emancipação social pode ser determinado como uma mera modificação do interesse mais amplo da humanidade por tornar-se independente da natureza e atribui à economia política, portanto, o desenvolvimento da análise racional das potencialidades do presente e a articulação, a partir desse horizonte, do conteúdo de verdade dos produtos das outras esferas da realidade social (política, cultura, psicologia). ${ }^{61}$ A relação entre teoria e práxis que estabelece esta fundamentação da teoria crítica só transforma em algo significativo o interesse pré-teórico (quase-naturalista) pela emancipação da natureza. A universalidade que esse interesse assume deveria bastar para operar como critério da consideração crítica dos bloqueios e os desvios da história, nos termos de uma racionalidade potencial alcançada pelo processo histórico, que não chegou a ser atualizada efetivamente na sociedade.

\footnotetext{
${ }^{61}$ Cfr, Honneth (1997): 20.
} 
Honneth constata, já nesta primeira fundamentação, o que ele denomina "déficit sociológico" da teoria crítica, que se transformará num déficit teórico importante quando a dialética entre as forças produtivas e as relações sociais de produção comece a manifestar problemas para conceber o sentido oculto da cena política moderna (como efetivamente aconteceu frente ao fascismo e ao nazismo, as duas grandes fantasmagorias políticas da modernidade tardia). Por este caminho, quando se dê o bloqueio do desenvolvimento das forças produtivas em algumas de suas determinações qualitativas (ex.: o desenvolvimento da consciência crítica do proletariado) ou, pior ainda, quando a aceleração de seu desenvolvimento não traga consigo nenhuma superação das relações sociais de dominação, então, a perspectiva teórica que conserve este critério de racionalidade ver-se-á forçada a cair num profundo ceticismo em relação à possibilidade de realizar socialmente $a$ razão. E perderá, conseqüentemente, a capacidade de interpretar teoricamente o sentido contido nas "fantasmagorias" dos conflitos sociais manifestos e das distintas formas de resistência ao poder que não possam ser enquadradas adequadamente no modelo épico da transformação revolucionária das relações sociais de produção a partir do desenvolvimento das forças produtivas.

Esta acusação de Honneth contém, implicitamente, uma crítica ao tipo de marxismo que Horkheimer haveria decidido recomeçar. Para Honneth, este primeiro projeto de Horkheimer aparece como "muito marxista", pelo tipo de reconstrução que faz da racionalidade na história, dependente da dialética entre forças produtivas e relações de produção, e, ao mesmo tempo, como "muito pouco marxista", pelo escasso ou virtualmente nulo valor atribuído às lutas sociais para explicar o processo histórico. Isto se tornaria ainda mais evidente, como veremos a seguir, na análise da fase do capitalismo que os países desenvolvidos transitavam desde começos do século XX. Este diagnóstico comprova um profundo bloqueio da dialética da história e um desvio em relação à atualização social da racionalidade potencial efetivamente alcançada na modernidade tardia. Entretanto, por não ter abandonado a teoria da história marxista, só pode pensar esse desvio como uma "realização perversa" do desenvolvimento das forças produtivas, abandonando assim definitivamente a dimensão constitutiva dos conflitos sociais, a instância na qual os movimentos sociais se tornam sujeitos de sua própria história, onde a cultura se transforma num território em permanente disputa. 
Quando Honneth tem que explicar as causas do déficit sociológico da primeira geração da teoria crítica, atribui um papel de enorme relevância à releitura da economia política marxiana realizada por Friedrich Pollock entre os anos 20'e 30 . ${ }^{62}$ Segundo esta releitura, a última fase do capitalismo monopolista tinha transformado radicalmente a relação que existia previamente entre a economia e as instituições estatais, sujeitando as determinações de mercado (preços e investimentos) a um planejamento centralizado da produção e do consumo. Na perspectiva de Pollock, o capitalismo pós-liberal tinha produzido uma "superação do capitalismo" dentro do próprio capitalismo, dando lugar ao que ele chamou de "capitalismo de Estado" (Staatskapitalismus). ${ }^{63}$

A idéia de Pollock sobre o capitalismo de Estado está rodeada de maus entendidos, que dificultam uma correta compreensão de seu diagnóstico sobre a fase do capitalismo que vivia a economia mundial nos começos do século $\mathrm{XX}$, e da teoria marxista do poder (e as transformações dessa teoria) da qual esse diagnóstico dependia. Nesse sentido, é preciso fazer um esclarecimento preliminar. O tipo de relação entre a economia e a esfera político-

\footnotetext{
${ }^{62}$ Cfr., Honneth (1995): 68.

${ }^{63}$ Ver, Pollock, F.: "State capitalism: Its possibilities and limitations", in: Critical Theory and Society, New York, Routledge, 1989. En una versión simplificada, las principales diferencias que encuentra Pollock entre el "capitalismo de Estado" y el "capitalismo liberal" pueden ser sintetizadas en tres grandes transformaciones de la relación economía-Estado:
}

a) En primer término, la supresión del mercado como agente regulador y coordinador de la producción y la distribución. En su lugar se erigen sistemas estatales de control directo, que interfieren con plenos poderes sobre la libertad de comercio, empresa y trabajo.

b) En segundo lugar, los nuevos controles estatales creados para intervenir en la economía tienen un objetivo preciso, que no existía en el capitalismo liberal: garantizar el pleno empleo de las fuerzas productivas (tanto de la fuerza de trabajo como de los medios de producción disponibles). Esta regulación no implica, sin embargo, la organización de la producción al servicio de las necesidades del consumo de la población. Por el contrario, lo que esta regulación promueve, en términos generales, es la planificación del consumo para ponerlo al servicio de la producción y reproducción del plus-valor.

c) Finalmente, en su forma decididamente totalitaria, el capitalismo de estado expresa a una nueva clase dominante, conformada por los intereses de los dueños de los monopolios, los directores de la industria y el management empresarial, el estrato superior de la burocracia estatal (incluyendo a los militares) y los líderes más relevantes del partido de gobierno. El resto, todos aquellos que no pertenecen al grupo que ejerce el poder, son reducidos a objetos de dominación, a través de mecanismos jurídicos y económico-administrativos. 
estatal que Pollock tenta fazer visível mediante o conceito de "capitalismo de Estado" não supõe assumir como um acontecimento crucial o fim das ilusões sobre os supostos benefícios coletivos da política econômica do laissez faire, nem se limita a conceitualizar as novas formas de intervenção estatal sobre a economia. ${ }^{64}$ A particularidade da análise de Pollock (algo que tanto Honneth quanto Habermas costumam subestimar) não está em repetir algo que todos os economistas da época afirmavam, isto é, o fato de o capitalismo ter requerido desde finais do século XIX, para sua própria reprodução, de uma maior intervenção do Estado em todos aqueles temas que - como assinalou Keynes em seu momento - "caem fora da esfera do indivíduo", dado que se trata de "decisões que ninguém toma se o Estado não o faz". ${ }^{65}$ A comparação e confrontação do conceito de Pollock com algumas das teses fundamentais que conduziram à ruptura de Keynes com a tradição da teoria econômica clássica pode ser útil para esclarecer este ponto. ${ }^{66}$

Se se analisar o conteúdo teórico básico de The General Theory of Employment, Interest and Money ${ }^{67}$, pode observar-se que, para Keynes, a representação clássica do

\footnotetext{
${ }^{64}$ En sí mismos, estos tópicos aparecen en todas las discusiones de los economistas de fines del siglo XIX y principios del siglo $\mathrm{XX}$, y se transformaron en una evidencia incontrovertible luego de la primera guerra mundial. De hecho, fue la propia dinámica de destrucción que provocó la guerra la que produjo este resultado en materia de pensamiento económico. Por un lado, la intensidad de la barbarie materializada en la guerra refutó de plano la justificación ético-política de la ideología del laissez-faire, que sostenía que en una sociedad en la cual se dejan actuar libremente los intereses de posesión y consumo de los individuos "los vicios privados se transforman siempre en virtudes públicas". Por otro lado, y como consecuencia de los propios requisitos que impuso la guerra, el Estado se transformó directamente en un agente económico de primer orden, tanto en la esfera de la producción industrial (al planificar lo que se conoció como "socialismo de guerra"), como en la esfera del sistema financiero (al transformarse las deudas públicas de los Estados y entre los Estados en el principal activo financiero de la economía de pos-guerra). Para un diagnóstico sumario y ejemplar de este clima de época en el discurso económico, ver: Keynes, J., The Economic Consequences of the Peace, ed. Harcourt, Brace, N.Y., 1920 y el opúsculo a este texto titulado: The End of Laissez-Faire, publicado por Hogarth Press, London, 1926.

${ }^{65}$ Keynes, J., The End of Laissez-Faire, ed. Hogarth Press, London, 1926, pág. 45.

${ }^{66}$ Una fecunda confrontación de las tesis de Keynes con las de Pollock requeriría, evidentemente, de un tipo de análisis que no podemos realizar en el presente trabajo. En lo que sigue nos limitamos a trazar exclusivamente los grandes rasgos de una problemática que no ha sido muy bien delimitada en la mayoría de los estudios sobre el pensamiento de Pollock, el cual posee, a nuestro entender, un valor muy superior al que frecuentemente se le asigna cuando se comenta su concepto de capitalismo de Estado.
}

${ }^{67}$ Ver, Keynes, J., The General Theory of Employment, Interest and Money, Macmillan Cambridge University Press, 1936. 
capitalismo liberal, apoiada nos princípios de liberdade absoluta na disposição da propriedade e liberdade absoluta de comércio, significava tanto uma orientação de política econômica equivocada, quanto uma ilusão sobre o funcionamento efetivo do capitalismo. Contra o que é habitual pensar, este segundo aspecto de sua reflexão é o mais importante. De fato, sua teoria é uma "teoria geral da economia" porque se propõe explicar todas as relações entre a oferta e a demanda que uma economia de livre empresa faz possíveis, e não só as "situações ideais", que partem do pressuposto de que "toda oferta gera sua própria demanda" (lei de J. B. Say ou "lei dos mercados") e de que os estímulos de mercado produzem uma auto-regulação entre a produção e o consumo. A economia clássica é para Keynes exclusivamente a teoria de um caso especial, que não considera a flutuação entre pleno-emprego e desemprego generalizado na dinâmica própria do capitalismo. Sob este ponto de vista, sua crítica à doutrina do laissez faire consiste numa dramática apelação ao realismo, um chamado a enfrentar conscientemente a "verdadeira natureza do mercado capitalista" o qual, segundo ele, nunca funcionou, nem poderá funcionar por conta própria no futuro, seguindo os pressupostos da doutrina clássica de pleno emprego dos recursos, transparência na informação e total conhecimento de seus interesses por parte dos indivíduos que participam do intercâmbio. ${ }^{68}$

\footnotetext{
${ }^{68}$ Keynes, J., The End of Laissez-Faire, ed. Hogarth Press, London, 1926, pág. 40: "Let us clear from the ground the metaphysical or general principles upon which, from time to time, laissez-faire has been founded. It is not true that individuals possess a prescriptive 'natural liberty' in their economic activities. There is no 'contract' conferring perpetual rights on those who Have or on those who Acquire. The world is not so governed from above that private and social interest always coincide. It is not so managed here below that in practice they coincide. It is not a correct deduction from the principles of economics that enlightened self-interest always operates in the public interest. Nor is it true that self-interest generally is enlightened; more often individuals acting separately to promote their own ends are too ignorant or too weak to attain even these. Experience does not show that individuals, when they make up a social unit, are always less clear-sighted than when they act separately. We cannot therefore settle on abstract grounds, but must handle on its merits in detail what Burke termed "one of the finest problems in legislation, namely, to determine what the State ought to take upon itself to direct by the public wisdom, and what it ought to leave, with as little interference as possible, to individual exertion» (Quoted by McCulloch in his Principles of Political Economy). We have to discriminate between what Bentham, in his forgotten but useful nomenclature, used to term Agenda and Non-Agenda, and to do this without Bentham's prior presumption that interference is, at the same time, 'generally needless' and 'generally pernicious.' (Bentham's Manual of Political Economy, published posthumously, in Bowring's edition - 1843). Perhaps the chief task of economists at this hour is to distinguish afresh the Agenda of government from the Non-Agenda; and the companion task of politics is to devise forms of government within a democracy which shall be capable of accomplishing the Agenda."
} 
A teoria de Keynes também é uma teoria geral porque leva em consideração os agregados totais de investimento, oferta, emprego, demanda e poupança de uma economia, deixando de lado a perspectiva clássica que analisa as relações entre a oferta e a demanda de bens e capital situando-se sempre na perspectiva do empresário particular. A crítica de Keynes pretende mostrar, precisamente, que os comportamentos racionais dos indivíduos que tendem a maximizar a utilização dos recursos limitados dos quais dispõem, desencadeiam - se se analisar o conjunto das variáveis em jogo - um desempenho regularmente instável da economia, que não pode ser previsto, porém, da perspectiva particular de nenhum dos indivíduos. Quer dizer, a racionalidade dos indivíduos econômicos está muito longe de encarnar a racionalidade da totalidade da economia, existindo situações nas quais aquela se constitui no obstáculo que impede a compreensão das leis que regulam esta última. O que Keynes procura com sua teoria geral da economia é tornar conscientes estas regularidades e estas leis do desempenho da totalidade da economia capitalista, para além das concepções idealizadoras da teoria econômica clássica.

O descobrimento da opacidade efetiva que existe nos mercados permitirá a Keynes predizer desequilíbrios regulares na produção e no valor econômico dos bens que neles circulam, desequilíbrios que dão origem às variações e às crises no ciclo de reprodução do capital. Tais desequilíbrios que se produzem no mercado (por exemplo, o que existe periodicamente no mercado do dinheiro entre a poupança e o investimento necessário para conservar e aumentar o emprego) mostram, por sua vez, assimetrias na informação e o poder dos agentes econômicos. Este é o ponto crucial que conduziu Keynes a rechaçar por ilusória a doutrina do laissez-faire. Em relação com o que nos interessa aqui, podemos observar que já para Keynes o fim do capitalismo liberal, entendido como uma fase histórica na qual teriam regido os princípios reguladores do laissez-faire, só significava o fim de uma ilusão, pois em sentido estrito nunca existiu uma economia regida pela liberdade absoluta de seus membros para dispor de seu trabalho e sua propriedade, em igualdade de condições de poder e informação com respeito a todos os outros indivíduos que intercambiam seus produtos no mercado.

Segundo interpretou Keynes, a única mudança significativa que introduziu o período de pós-guerra foi a consciência sobre o caráter ilusório dos princípios "liberais" do mercado, revelando-se, ao mesmo tempo, que em toda economia capitalista existem agentes 
e instituições que centralizam a informação e o poder, os quais podem acentuar os desequilíbrios ou atuar como uma instância de regulação coordenada que não permita ou que dilua os efeitos das crises periódicas. Estes agentes e instituições que centralizam o poder e a informação podem ser tanto estatais quanto privados. O importante é que eles já não aparecem como o resultado não desejado do desenvolvimento das "leis naturais da economia", mas como a condição de possibilidade da reprodução da sociedade através das relações de mercado. O exemplo típico que utiliza Keynes é o da autoridade monetária (estatal) e os grandes bancos de investimento (empresas privadas). O banco central de um país e os grandes bancos de investimento não são, em sentido estrito, o resultado não desejado de uma economia de mercado, mas são sua condição absoluta de possibilidade, precisamente por sua capacidade para monopolizar a emissão de dinheiro e concentrar as decisões sobre os fluxos de investimento.

Quando reclama o fim do capitalismo liberal, Keynes não propõe criar, portanto, algo completamente novo dentro da economia capitalista. $\mathrm{O}$ que ele propõe é que esses agentes e instituições que centralizam poder e informação econômica o façam de maneira mais racional, coordenando suas ações entre si, tornando-se autoconscientes do lugar e da repercussão de seu comportamento sobre o conjunto das variáveis e os agentes econômicos. O conceito keynesiano de intervenção estatal tem que ser entendido no quadro de seu grande descobrimento (a opacidade natural dos mercados e a existência de agentes e instituições assimétricas), sem adjudicar imediatamente à história real uma divisão rígida (e ilusória) entre uma etapa na qual o Estado (ou empresas privadas com capacidade de centralizar um volume de poder e informação equivalente) não intervinha sobre a economia e outra na qual o Estado intervém, regula e centraliza a direção da atividade econômica. Sua grande recomendação em matéria de política econômica - a regulação contra-cíclica da taxa de juros e o investimento público orientado a suprir e estimular o investimento contra a economia improdutiva - são mostras claras do que Keynes entende como intervenção estatal sobre a economia. O Estado aparece aqui como uma instância na qual, através da pressão da opinião pública, os pontos de concentração de poder e informação econômica podem ser utilizados de modo "mais racional" para satisfazer os interesses coletivos.

Para Keynes, portanto, o capitalismo pós-liberal ou capitalismo de intervenção estatal na economia, não significava senão o fim de uma ilusão perniciosa contida nas teses 
do laissez-faire, junto com a possibilidade de chegar a um planejamento e regulação democrática das instâncias econômicas que concentram "naturalmente", numa economia de mercado: poder e informação (e que pré-existem, como já mostramos, à própria idéia de intervenção estatal). Deste modo, Keynes descobria também o dilema da regulação dos desequilíbrios inerentes ao ciclo econômico capitalista, já que esta regulação pode ser levada a cabo tanto pelo controle das instituições democráticas e a opinião pública, como pelos próprios monopólios privados ou formas de Estado não-democráticas. E é precisamente frente a esta complexa realidade que a interpretação de Pollock, segundo Honneth, teria fracassado. Seu conceito de capitalismo de Estado teria perdido a ambigüidade que o presente histórico manifestou contundentemente com a Primeira Guerra Mundial (1914-1918). Ao invés de considerar teoricamente as alternativas do desenvolvimento intrínseco ao capitalismo, Pollock haveria ressaltado uma única linha de avanço no desenvolvimento das sociedades capitalistas, aquela na qual a crescente concentração econômica se transforma, inevitavelmente, em controle absoluto das instituições públicas e das esferas de interação da sociedade civil (fundamentalmente o mercado e a opinião pública) por parte dos interesses dominantes.

Honneth chega, com esta crítica, a um resultado um tanto absurdo, mas que resultou eficaz e duradouro em termos de interpretação teórica. Segundo resulta da posição atribuída a Pollock na discussão dos anos 20' e 30', sua teoria teria sido vítima da ilusão da economia clássica, que acabava de ser refutada eficazmente por Keynes. Quer dizer, Pollock - que era um teórico marxista - teria afirmado, com seu conceito de capitalismo de Estado, que existiu efetivamente uma fase histórica do capitalismo na qual regeram os princípios do laissez-faire sem nenhuma interferência, fase que só foi interrompida posteriormente pela intervenção estatal na economia, que haveria modificado a natureza do modo de produção capitalista em um sentido pernicioso. Daí as ressonâncias nostálgicas em relação ao capitalismo liberal que por momentos se atribui ao conceito de capitalismo de Estado; ressonâncias que pretendem encontrar no conceito de Pollock a afirmação implícita que sustenta que o grau e a extensão da violência e do poder que caracteriza a fase do capitalismo de Estado se encontrava completamente ausente em sua "fase liberal". A este resultado chegam sempre a maioria das interpretações críticas da obra de Pollock. 
Nos textos nos quais Honneth pretende elaborar uma crítica integral da teoria da sociedade de Adorno e Horkheimer, ele não hesita em afirmar que o diagnóstico referido à nova fase da economia capitalista de Pollock depende de uma "leitura funcionalista" da herança de Marx, que o teria conduzido (e junto com ele, Adorno e Horkheimer) a negar, por um lado, as linhas de continuidade que efetivamente existiam entre o capitalismo pósliberal e o capitalismo liberal e, por outro lado, a subestimar a vigência dos conflitos sociais de classe dentro da nova fase do capitalismo. ${ }^{69}$ Esta negação e subestimação da interação social através do mercado e do conflito de classe pela distribuição do excedente através do Estado, teria sido logo generalizada por Horkheimer em sua teoria do Estado autoritário. ${ }^{70}$ Se para Pollock - desatendendo as alternativas abertas pelo diagnóstico de Keynes - o Estado se transformou em um instrumento de controle total sobre os agentes e as instituições econômicas, exercendo assim um planejamento autoritário da produção e do consumo (que se legitima a si mesmo a partir da neutralização das crises cíclicas), para Horkheimer esse tipo de dominação se estendeu à cultura, à sociedade e aos indivíduos.

No momento em que assume as teses de Pollock, Horkheimer começa a perder "sua confiança teórica no processo racional de dominação social sobre a natureza, que era o que lhe dava o tom esperançado no ensaio Traditional and Critical Theory; e isso produz, finalmente, um diagnóstico inesperadamente pessimista sobre o presente, que descreve a fase pós-liberal do capitalismo como um mundo da vida alterado" (Honneth, 1997: 32). Ora bem, pelos limites próprios deste marco teórico, Horkheimer só pode pensar a crescente regulação estatal da economia como "a formação de uma economia capitalista planejada, que subtrai as decisões econômicas dos pequenos empreendedores e as põe em mãos dos administradores das grandes empresas, provocando sérias mudanças nas condições sociais de individuação" (Ibid.). Para Horkheimer, "junto com a perda da capacidade de decisão, o pequeno proprietário também perde as bases cognitivas e morais de sua identidade" (Ibid.). Ao interior desta teoria do Estado total "os sujeitos são dirigidos cada vez em menor medida por um superego desenvolvido socialmente e ficam diretamente sob a influência de controles externos" (Honneth, 1997: 33). Desta maneira, “a «cultura» já não é um conceito

\footnotetext{
${ }^{69}$ Cfr. Honneth (1995): 70 y ss.

${ }^{70}$ Ver, Horkheimer, M., “Autoritärer Staat", in: Gesammelte Schriften, Band 5, Dialektik der Aufklärung und andere Schriften 1940-1950, Frankfurt am Main, 1987, pp. 293-319.
} 
amplo que faz referência à estrutura institucionalizada dos meios autônomos de socialização. Desde que o processo de industrialização capitalista penetrou nas regiões internas das instituições culturais e as pôs à disposição da influência direta dos poderes sociais de administração, a superestrutura cultural perdeu completamente seu «relativo poder de resistência»" (Ibid.).

O que Honneth denuncia nesta teoria do Estado autoritário já não é, como era no caso da ênfase habermasiana, uma teoria da racionalidade moderna abstrata e unilateral. $\mathrm{O}$ que ele encontra no centro dos erros da compreensão teórica da "primeira geração da Escola de Frankfurt" é uma teoria abstrata e unilateral do funcionamento do poder na modernidade. Por isso, sua avaliação negativa do legado da primeira formulação da teoria crítica não vai na direção de reconstruir o modelo normativo de uma "racionalidade não minguada", mas se propõe a cobrir o déficit sociológico dessa formulação a partir de uma teoria do poder que possa dar conta da complexa constituição e reprodução das sociedades no capitalismo tardio. Longe dos desafios desta problemática, a teoria do poder que teria ocupado, implícita e explicitamente, um papel explicativo destacado em Pollock, Horkheimer e Adorno, seria uma teoria pré-weberiana do poder, que o concebe como algo que pode exercer-se sem conflitos, sobre um objeto que não oferece resistência. ${ }^{71}$ Ao mesmo tempo, esta teoria também supõe que o poder opera em termos institucionais seguindo sempre uma direção única, de acima para baixo, fazendo-se presente como uma capacidade que detêm aqueles que ocupam as posições privilegiadas na hierarquia social institucionalizada, sem que possa existir da mesma maneira entre os não favorecidos pelas instituições.

Evidentemente, a crítica honnethiana do conceito de poder de Pollock, Horkheimer e Adorno tem muito presente a crítica feita por Foucault à teoria marxista do poder. As três críticas que Foucault dirige ao "economicismo" implícito na teoria marxista do poder constituem também os tópicos que implicitamente escolhe Honneth para reprovar o conceito de poder que surge das teses de Pollock sobre o capitalismo de Estado, isto é: a) que só podem conceber o poder como um objeto suscetível de apropriação, como um instrumento que se pode utilizar com vistas a um fim ou para produzir um efeito qualquer

\footnotetext{
${ }^{71}$ Cfr., Honneth (1997): 49-56.
} 
(e não podem, pelo contrário, pensar o poder como uma relação, como uma perpétua correlação de forças que se tornam, por si próprias, algo produtivo, algo ontologicamente positivo, enquanto forças e perspectivas em conflito); b) que só podem conceber o poder em função da exploração econômica da força de trabalho; e c) que não podem pensar o poder para além do Estado. A idéia de Estado autoritário de Horkheimer reproduziria esses três erros, ao sancionar o caráter total da dominação dos indivíduos nas condições do capitalismo de Estado, ao reafirmar a finalidade essencialmente econômica dessa dominação e ao espacializar seu modo particular de existência nas respectivas instituições e aparelhos estatais. O diagnóstico desta fragilidade teórica respalda o juízo que nós antecipamos, o qual considera que a teoria da sociedade de Adorno e Horkheimer possui uma chave interpretativa "muito marxista" e, ao mesmo tempo, "muito pouco marxista" para explicar os desafios da política moderna.

Finalmente, esse conceito unilateral do poder é o que tornará impossível, num duplo sentido, a teoria social crítica. Por um lado, esta posição perde de vista o conflito como a autêntica substância da vida social, somando-se portanto, involuntariamente, às teorias políticas e sociológicas conservadoras que pretendem eliminar os conflitos sociais do horizonte explicativo da constituição e reprodução da sociedade (para substituí-los pelas diversas figuras do consenso e a comunidade). Por outro lado, ao eliminar o caráter relacional do poder, vêem-se obrigados a desprezar completamente a instância da resistência à dominação e, junto com ela, o interesse pela emancipação que devia servir de correlato prático da teoria crítica. Sob o Estado autoritário de Horkheimer "a experiência da sujeição e a exploração social foi, por dizê-lo assim, bloqueada e reprimida por uma consciência falsificadora que, operando ao nível dos instintos, impede que essa experiência possa tornar-se cognoscível" (Honneth, 1997: 22). Daí que "o descobrimento cognitivo da realidade social, graças ao qual o eu poderia perceber a injustiça e repará-la, se veja frustrado por um processo dinâmico de repressão e denegação que substitui a percepção da própria impotência com a experiência imaginária de um falso poder pessoal e coletivo" (Ibid.). Quando a teoria chega a esta conclusão, apoiada numa interpretação unilateral das transformações do capitalismo tardio, suprime qualquer possível relação com os fundamentos práticos da crítica social: a consciência da injustiça social e a potência coletiva para transformá-la. O fantasma do Estado Total acaba com a possibilidade de 
construir um marco conceitual adequado para interpretar criticamente as fantasmagorias políticas da modernidade. Sobre o fundo desse fracasso, Keynes e Foucault trabalham de forma coordenada para subtrair legitimidade, no campo da teoria da sociedade, a Pollock e a Horkheimer.

Nesta parte de sua interpretação, o que é notável, entretanto, é que Honneth não considera o ponto central da crítica de Pollock e Horkheimer ao capitalismo de Estado. Ao considerar a prática da intervenção estatal tal como a concebe Keynes, Honneth desloca o centro do problema. Para Keynes - e para Foucault (?) - o capital aparece essencialmente sob a forma de um objeto que se possui, como um stock de recursos materiais e humanos, que logo podem utilizar-se para distintos fins econômicos, desencadeando diversas lutas de poder em relação a seu uso por parte dos distintos agentes econômicos. O que Keynes põe em discussão com a idéia de intervenção estatal sobre a economia é o problema de investigar quem se apropria do capital disponível numa sociedade, e sob qual racionalidade (com que previsão do futuro) utiliza esse instrumento objetivo. Para Pollock, pelo contrário, o capital não é - como não era tampouco para Marx - um simples stock de recursos “objetivos”, mas a relação social fundamental do capitalismo (e do socialismo de Estado), que depende da separação dos trabalhadores dos meios de vida e de produção, e da objetivação desses meios na forma de algo estranho e antagônico em relação aos trabalhadores. ${ }^{72}$ Quando se refere à nova forma que assume o Estado no capitalismo tardio, Pollock está pensando precisamente nas novas formas que assumem as relações de poder que tendem a reproduzir o capital enquanto relação social, quer dizer, as novas formas de violência e controle que produzem permanentemente, em silêncio e longe do olhar do público, o tipo de separação e objetivação dos meios de produção que Marx analisou em seu famoso capítulo referente à acumulação originária do capital.

Indiscutivelmente, o rastro mais eloqüente do conceito de capitalismo de Estado se dirigia nessa direção, afirmando que se estava produzindo na textura profunda das relações sociais uma repetição do processo de acumulação violenta de capital. Esta afirmação deixa num segundo plano a descrição do processo visível de "regulação" dos fluxos e os grandes agregados da economia tipicamente keynesiana. O conceito de capitalismo de Estado

\footnotetext{
${ }^{72}$ Una notable ampliación de esta problemática puede encontrarse en, Adorno (PE): 93-99.
} 
pretendia tornar visível esse processo - a re-inscrição da violência que se oculta recorrentemente por trás da "acumulação normal" do capital, tanto na fase "liberal" quanto na fase "pós-liberal" do capitalismo. O que o conceito de Pollock propunha era pensar sempre em forma conjunta a história e a pré-história do capital, a acumulação de capital que se produz a partir de médios puramente econômicos e a acumulação que se produz através dos meios extra-econômicos. Sua superposição extemporânea, a presença do "passado longínquo" da acumulação originária no presente avançado e saturado de progresso do capitalismo tardio, era o que o conceito de capitalismo de Estado queria mostrar, evitando assim a interpretação "idealizadora" de uma suposta fase "puramente liberal" do capitalismo, que em muitas ocasiões se atribui - interessadamente - ao próprio Pollock. ${ }^{73}$ Esta teoria, que articula em termos sincrônicos a acumulação "normal" e a acumulação "originária" do capital, pode ser a explicação, pelo menos no que diz respeito ao ponto de vista de uma teoria da sociedade, dos "anacronismos", das conexões filosóficas "indemonstráveis" e de tudo aquilo que Habermas e Honneth não cessam de atribuir à "irracionalidade" da Dialética da Ilustração. Se a acumulação de capital é algo que nunca pode realizar-se através de meios exclusivamente econômicos, então, em todos os casos,

\footnotetext{
${ }^{73}$ Honneth explicita este malentendido en una crítica que le dirige a Adorno: "Adorno makes use of such a vague conception as early as 1942 in "Reflections on Class Theory». In that essay the point of his interpretation of «state capitalism» is still formulated in terms of the philosophical-historical claim that to a certain extent the cycle of civilization comes to a close with the end of liberal capitalism since, with the formation, after the interlude of economically induced class conflict, of an administrative elite who exercise control, a piece of human prehistory returns -the arbitrary and violent appropriation of power by social groups. The sharply formulated opposition between a noninterventionist market economy and a statecapitalism central administration, which in view of fascism Adorno subsequently used as the basis for regarding the liberal phase of capitalism as simply an episode in the history of noneconomic acts of domination, remains the theoretical element that also provides an argumentative framework for his postwar sociological writings", Honneth (1997): 72-73. En este pasaje la confusión, en términos económicos y políticos, llega a su extremo. Adorno aparece aquí sosteniendo que el intervencionismo estatal es el responsable por el fin del "ciclo civilizatorio" que se habría originado con el "capitalismo liberal". El carácter profundamente interesado de esta lectura también se vuelve transparente. Finalmente, lo que Adorno no habría percibido (junto con Pollock y Horkheimer) es que existían dos (o más) formas de intervencionismo estatal: la bárbara (el fascismo) y la civilizada (el keynesianismo). Y como esta última variante del intervencionismo estatal comienza a transformarse en una especie de horizonte intraspasable para la teoría crítica, su legitimación teórica, en la forma del Estado social de bienestar, es la que obscurece su consideración de la "primera generación de la Escuela de Frankfurt". Se llega al colmo de esta confusión cuando se le asigna a Adorno, Horkheimer y Pollock la defensa del viejo (y buen) capitalismo liberal frente al nuevo (y malo) capitalismo de estado.
} 
sua explicação deve ampliar-se no sentido de indagar todas aquelas formas de violência material e simbólica que a interpretação liberal-progressista da história gostaria de considerar como algo definitivamente superado ou como algo que só pode "reaparecer" sob a forma de um acidente excepcional que reintroduz fugazmente a lógica política que prevalecia em "tempos remotos". A Dialética da Ilustração conecta-se com as teses de Pollock precisamente porque desmente enfaticamente esta interpretação da história, demonstrando a falácia em que cai quem atribui a essa obra qualquer tipo de "idealização" do capitalismo liberal.

Frente a esta concepção, resulta muito mais difícil corroborar as clássicas objeções de Foucault ao conceito marxista de poder, porque na interpretação de Pollock é precisamente o próprio conceito de capital que exige ser pensado como uma relação social de forças enfrentadas e não como um objeto; é o capital o que envolve mecanismos e formas de violência que não se limitam à luta pela distribuição do excedente econômico (já que se referem à separação e à objetivação fundadoras de toda agência e instituição econômica); e é também o conceito de capital o que, implicando uma determinada relação estrutural com o Estado, existe sempre além do Estado. O capital como cristalização de relações sociais, o capital como o fóssil secreto que põe em movimento a vida das sociedades modernas, era o que a teoria crítica da sociedade, tanto para Pollock quanto para Horkheimer, devia tentar compreender, e não os movimentos visíveis e o funcionamento visível dos sujeitos econômicos (já constituídos) e as instituições políticas (já estruturadas). Para Pollock e Horkheimer, o capitalismo tardio colocou na ordem do dia, por sua intensidade e extensão, o problema das formas objetivas do poder do capital. Mas ao invés de explorar de novo o conteúdo deste argumento, Honneth, com sua crítica do conceito de capitalismo de Estado, decide conceber o poder só dentro dos limites estreitos que oferece a esfera da intersubjetividade. Deste modo, só pode pensá-lo quando "circula" ou se "exerce" manifestamente entre sujeitos já constituídos ou em processo de constituição (dando origem, assim, ao grande motivo de sua teoria social: as diversas formas da “dialética do reconhecimento"). Segundo nosso entender, Honneth deixa atrás, com este movimento, um elemento essencial para a teoria crítica, que tentaremos retomar em nosso trabalho a partir da releitura adorniana do marxismo. 
b) A opacidade radical do social e a ideologia frankfurtiana

As análises filosóficas e culturais que Adorno e Horkheimer desenvolveram a partir da década de 1930 colocam frontalmente a pergunta sócio-política que tinha deixado pendente a pesquisa de Pollock: por que os indivíduos toleram sem resistência esta nova forma de controle? Para responder a esta pergunta, começa a adquirir um papel destacado o trabalho conjunto de Adorno e Horkheimer, pois é a partir de seus trabalhos teóricos e suas análises sociais empíricas que ganha relevância dentro da teoria crítica a explicação de uma dupla neutralização das energias emancipatórias do sujeito. Por um lado, apoiando-se originalmente em Freud, Adorno e Horkheimer afirmam que o capitalismo de Estado não só liquidou a importância do indivíduo no mercado, mas também anulou completamente seu papel estruturante dentro da família burguesa tradicional. Com a perda de seu poder econômico, o homem ativo também perdia sua autoridade dentro da família, debilitando-se drasticamente o ponto de referência idealizado que servia para o desenvolvimento, em seus filhos, de um eu forte. A destruição, operada pelo capitalismo de Estado, desse núcleo familiar, colaborava com a dominação no plano da formação subjetiva por meio da criação de indivíduos fracos, suscetíveis de fácil manipulação e de liberarem, sob a modalidade agressiva de uma "personalidade autoritária" funcional ao sistema de domínio, os restos pulsionais que essa mesma dominação não chegava a controlar. Por outro lado, a análise adorniana da cultura de massas revela a crescente importância que adquirem, no capitalismo de Estado, os "aparelhos" centralizados que regulam e organizam a reprodução cultural. Esta ideia do aparelho administrativo que assedia e reprime o indivíduo, que o confronta com uma série de valores e padrões de comportamento que ele só pode aceitar, evoca, no campo específico da cultura, a ideia do controle burocrático sobre todos os aspectos da vida econômica que Pollock desenvolveu com seu conceito de capitalismo de Estado. Com esta dupla neutralização do indivíduo e da cultura, Adorno e Horkheimer completaram seu olhar do tempo contemporâneo como um momento de dominação total.

Honneth considera que, no começo da década de 40', o potencial emancipatório que Horkheimer identificava ainda com o progresso da razão (dominadora da natureza) é 
finalmente liquidado, ao entrarem em cena as teses de Adorno ${ }^{74}$ que somente reconhecem no desenvolvimento do capitalismo tardio: a) um processo de autodestruição da razão humana; b) um processo sócio-psicológico de perda da personalidade humana; e c) um processo de consolidação do caráter alienado e destrutivo da cultura de massas.

Adorno aparece, nesta interpretação de Honneth, como o principal responsável pelos deslocamentos teóricos que cancelam progressivamente as ambiguidades em relação ao processo de modernização social que continha a crítica de Horkheimer. Se as teses deste último vacilavam entre uma filosofia da história de corte racionalista e uma teoria da economia e do Estado que ainda atribuía à ação social e ao conflito de classes um papel destacado, com a intervenção de Adorno todos esses elementos desaparecem do horizonte da teoria crítica. No centro do processo de "autodestruição" social iniciado pela modernidade avançada, Adorno só concebe uma (frágil) instância capaz de se diferenciar e resistir à influência dos mecanismos de controle do "mundo administrado": a arte. O resto, a experiência polimorfa do corpo, os interesses individuais autoconscientes, a luta dos movimentos sociais pelo reconhecimento jurídico-normativo de seus valores morais, a práxis política e as crises recorrentes dos paradigmas culturais na modernidade tardia, tornam-se momentos completamente neutralizados ou socialmente reintegráveis pela dominação da racionalidade administrativa. Adorno se torna assim uma espécie de Pollock radicalizado, que destitui do campo social, por meio de sua teoria da cultura no capitalismo tardio, qualquer instância de resistência ou contrapoder.

É importante sublinhar que Adorno encarna este papel de Supremo Pontífice da profecia negra a respeito do destino das sociedades modernas avançadas por motivos que não são arbitrários. Isto se deve ao fato de que foi Adorno quem desenvolveu as análises culturais que tentavam fazer um mapeamento dos efeitos globais do processo de modernização, enquanto é justamente no campo da teoria da cultura onde Honneth e Habermas vão expor sua crítica mais enfática aos déficits teóricos e de diagnóstico da “primeira geração da Escola de Frankfurt”. Para ambos, a dimensão cultural transforma-se numa instância decisiva, ainda que por motivos diferentes (que se complementam). ${ }^{75}$

\footnotetext{
${ }^{74}$ Ver Honneth (1997): 35 e ss.

${ }^{75}$ Cfr., Honneth (1997): 64 e ss.
} 
Habermas incorpora-se na discussão da dimensão cultural das sociedades modernas avançadas a partir de seu interesse por vincular a teoria crítica com a crítica imanente das tentativas modernas de fundamentação da razão. Para dizê-lo de uma forma não totalmente metafórica, ele chega aos problemas da esfera cultural da sociedade "de cima", com o objetivo de constatar as dificuldades e as barreiras que apresentam historicamente as distintas pretensões da racionalidade moderna (verdade, justiça, autenticidade). O movimento de sua "crítica conscientizadora" (Bewußtmachende) dos impasses da racionalidade moderna encontra na análise da dinâmica cultural um espaço fecundo de concretude sócio-histórica. Por sua vez, a conexão à qual aspira entre o terreno estritamente filosófico e o espaço cultural da problemática da razão permitirá a Habermas construir um dos tópicos nucleares de sua própria teoria da ação comunicativa, que se apoia no conceito de "esfera pública" (Öffentlichkeit). Com efeito, para Habermas a esfera pública representa o traço que melhor caracteriza a cultura moderna, porque as formas diferenciadas de racionalidade só podem realizar-se nela e por meio dela, e, ao mesmo tempo, porque as regras constitutivas da esfera pública representam a forma que assume a esfera de validez normativa quando configurada "racionalmente". Para dizê-lo com uma fórmula hegeliana que não é completamente estranha ao pensamento de Habermas: é na esfera pública onde se decide a realidade da razão e a racionalidade da realidade social. Resulta relativamente simples perceber, ao estudar a obra de Habermas, que a centralidade do conceito de esfera pública depende de uma análise da dimensão cultural das sociedades modernas avançadas que pretende constatar formas sociais de racionalidade que tinham sido desconsideradas por Adorno e Horkheimer. Em Habermas, de algum modo, o conceito de esfera pública se opõe ao conceito de "indústria cultural" da Dialética da Ilustração, porque transforma a cultura numa instância de mediação entre as formas de racionalidade e a sociedade que foi cancelada no diagnóstico implícito ao conceito de indústria cultural. Permitimo-nos falar de estruturação da cultura "de cima" nos casos em que se reconstroem seus conceitos fundamentais e se concebem suas articulações com a sociedade seguindo esta modalidade habermasiana, que coloca no centro da construção os problemas filosóficos da racionalidade. Em qualquer caso, dir-se-á, este modelo teórico ganha uma dimensão que não existe na teoria da sociedade de Adorno e Horkheimer. Ainda quando pensada "de cima”, a cultura ganha com Habermas, a partir do conceito de esfera pública, um grau de 
autonomia e complexidade que se teria desvanecido por completo no conceito de indústria cultural.

A preocupação de Honneth é devolver à cultura a mesma centralidade "mediadora" (entre o indivíduo e a sociedade, entre os movimentos sociais e o Estado, entre a sociedade e a história etc.) que procura a obra de Habermas, mas tenta evitar - como ele próprio o manifesta - suas pretensões "excessivamente racionalistas". Para realizar a mesma crítica ao legado de Adorno e Horkheimer, mas sem a exigência rígida de pensar a cultura moderna somente sob o prisma que fornecem as formas "diferenciadas e complementares de racionalidade", ele se propõe realizar essa operação "de baixo", a partir das mais primitivas formas de "reconhecimento intersubjetivo". O interesse de Honneth consiste em demonstrar que as análises de Adorno (que se encaminham desde cedo para o conceito de indústria cultural) sancionam uma opacidade tão radical da cultura, que terminam apagando do horizonte da teoria crítica não só as tentativas orientadas a fundamentar socialmente a razão, mas também a própria textura conflitiva do social. O que Honneth pretende mostrar com sua crítica é que a teorização de Adorno (diferentemente das ambiguidades que continham as teses do primeiro Horkheimer) impede o "trabalho hermenêutico" que tem por objetivo ler na trama simbólica de uma sociedade a presença dos conflitos e das diversas formas de reconhecimento intersubjetivo que originam esse tecido cultural. Inspirado em Hegel, ele concebe esta dinâmica social da cultura como um processo sempre renovado de "luta pelo reconhecimento" intersubjetivo.

Ao contrário, em Adorno o simbólico apareceria somente como produto do poder e como instrumento de domínio, perdendo-se, portanto, a autonomia e a substancialidade relativa de sua função mediadora. ${ }^{76}$ Esta perda, como tivemos ocasião de analisar

\footnotetext{
76 “Adorno's early essays on the commodity character of Works of art produced on a standardized scale and Horkheimer's studies on the bifurcation of contemporary culture were joined together in a chapter in the Dialectic of Enlightenment entitled «The Culture Industry: Enlightenment as Mass Deception». This chapter examines the administrative use of electronic media as a "means for the enchainment of consciousness» and sets forth a model that Adorno simply carries over into his later studies on the cultural scene in the postwar era. According to this model, on the basis of a monopolistic economic system, the modern reproductive techniques of film, radio, and television are fused with the rapidly spreading entertainment industry into a cultural-industrial complex whose manipulative products make it possible to control individual consciousness at the level of motivations. Adorno is also convinced that, in aesthetic presentation as well as in informational content, the products of the culture industry affect the members of society in such a way that they willing undertake administratively sanctioned tasks." Honneth (1997): 77.
} 
anteriormente no caso de Habermas, também é pensada como resultado de uma incorreta e imprudente "dissolução da distinção entre faticidade e validez". Este lema da crítica de Habermas, que reaparece agora em um contexto diferente, depende igualmente de uma valoração teórica positiva do conceito de esfera pública. Também para Honneth a ideia de esfera pública representa o conceito mais adequado para pensar a cultura na modernidade e para reconstruir critérios normativos imanentes ao desenvolvimento social (implicitamente, ele também apela aqui a uma teoria da evolução social) que sirvam para criticar a configuração efetiva das relações sociais. É claro, entretanto, que Honneth já não pensará a esfera pública como instância reguladora das "condições ideais para a Razão", mas sim como o resultado de condições psicológicas, sociais, jurídicas e culturais que permitem um tipo de "reconhecimento intersubjetivo" democrático e plural, capaz de institucionalizar uma abertura tal dos quadros simbólicos e normativos de uma sociedade, que transforma os conflitos na autêntica "gramática moral" das sociedades. Para Honneth - que é neste aspecto mais weberiano que Habermas -, a esfera pública é o espaço social no qual os indivíduos e os diversos movimentos sociais travam entre si uma luta para obter dos outros o reconhecimento de si mesmos e de seus valores, sem que se possam estipular a priori outros fins ou pressupostos referentes à "racionalidade" desses conflitos. ${ }^{77}$

Assim, apesar de suas diferenças, Habermas e Honneth coincidem no julgamento que condena estrategicamente a teoria crítica de Adorno por ser incapaz, basicamente, de conceber a cultura como uma genuína instância mediadora. $\mathrm{O}$ que para ambos é o mesmo que dizer, quando se trata da cultura moderna, que o argumento teórico de Adorno é completamente incapaz de chegar a um conhecimento adequado da esfera pública intersubjetiva, tanto no referido a seus aspectos "racionais", quanto no que diz respeito à sua dimensão "ético-política". No outro polo desta incapacidade, a defesa fechada que realizam Habermas e Honneth do conceito de esfera pública demonstra a relevância que atribuem a esta discussão. Quando se analisa com cuidado sua estratégia argumentativa, vêse que aquilo que está sendo discutido nesta crítica a Adorno não é, simplesmente, a exigência de uma maior precisão com respeito à natureza e aos limites de uma das dimensões da sociedade. A relevância que adquire o conceito de cultura não se pode dever

\footnotetext{
${ }^{77}$ Sob este aspecto, sem dúvida, a exposição de Honneth tende a "trascendentalizar" o critério normativo da teoria crítica em um grau muito inferior ao de Habermas.
} 
à sua função como teoria parcial. Em realidade, o que se torna manifesto na veemência que assume esta discussão em torno do conceito de cultura e da ideia de esfera pública, é que a teoria da cultura transforma-se progressivamente, para Habermas e Honneth, na teoria geral da sociedade (ou na matriz lógica e filosófica dessa teoria) - e é precisamente este o ponto no qual as análises culturais de Adorno funcionam como um obstáculo.

Por motivos que no fundo são complementares, tanto Habermas quanto Honneth precisam afirmar que a "primeira geração da Escola de Frankfurt" não tem, na verdade, um conceito de cultura; ${ }^{78}$ e desse modo podem logo asseverar que a teoria da sociedade de Pollock, Horkheimer e Adorno não estava preparada para enfrentar as controvérsias referidas aos fundamentos das ciências sociais acontecidas a partir da segunda metade do século XX sob o signo do giro linguístico. Este ponto resulta decisivo para entender por que Adorno ocupa um lugar especial na rejeição plasmada por Habermas (a partir de sua teoria da ação comunicativa) e Honneth (com sua teoria do reconhecimento). Como ambos atribuem à cultura um lugar privilegiado na reprodução social, devem produzir sua ruptura com a "primeira geração da Escola de Frankfurt", afirmando que esta foi incapaz de expor as implicâncias epistemológicas que a teoria da cultura adquiriu no campo da filosofia social durante o século XX. No centro desta ausência, a responsabilidade de Adorno é maior, porque ele era o encarregado de formular a teoria referida à especificidade e à autonomia que adquire na modernidade a dinâmica cultural da sociedade. Em vez disso, seu modelo teórico para pensar a integração e a reprodução social continuaria sendo o da economia política, dando-lhe, no máximo, um maior espaço à psicologia e à antropologia. Honneth explica deste modo por que, "sobre o fundo de um conceito de capitalismo liberal esvaziado da dimensão básica da esfera pública", têm necessariamente que aparecer os processos administrativos que centralizam as decisões econômicas que "ameaçam destruir a estrutura social interna do capitalismo em geral", dado que "esta direção burocrática da economia deformou o espaço aberto pelo mercado para as ações sociais orientadas à defesa dos próprios interesses, junto com as instituições sociais que se encarregam de mediar a ação individual” (Honneth, 1997: 75). A causa desta falsa interpretação deve encontrar-se na resistência de Adorno para com o conceito de esfera pública, que o leva a sancionar "o

\footnotetext{
${ }^{78}$ Cfr., Honneth (1997): 26-28 e 77-81.
} 
fim da mediação" sócio-cultural e faz que os imperativos do sistema econômico "encontrem-se diretamente com os membros individuais da sociedade, sem que sejam mediados por meio de nenhuma esfera de ação social" (Ibid.). Aquilo que Adorno descarta imprudentemente em suas análises culturais, e que teria sido um elemento indispensável para a formulação da dimensão crítica da teoria social, são "os domínios pré-estatais de ação, nos quais as convicções normativas e as autointerpretações culturais, assim como as deliberações individuais orientadas para o prosseguimento de um fim, transformam-se em algo socialmente efetivo" (Honneth, 1997: 76).

Se sistematizarmos as críticas de Habermas que analisamos no capítulo anterior, veremos as profundas coincidências que estas guardam com este diagnóstico de Honneth e poderemos constatar também a motivação teórica que compartilham. A teoria crítica de Habermas depende inteiramente de sua capacidade para fundamentar a distinção entre faticidade e validez a partir de uma perspectiva racionalista. A dimensão crítica da teoria da sociedade depende - para Habermas - de sua habilidade para reconhecer a diferença que existe entre as relações de sentido e as relações objetivas, diferenciando dentro das primeiras as pretensões de validez específicas da ciência, da moral e da arte. Para Habermas, este é um requisito lógico da teoria crítica da sociedade, que determina sua própria cientificidade. Só quando se conseguiu demonstrar essa diferença, que ele eleva a um estatuto quase ontológico, pode-se suspeitar de, e criticar a pretendida autonomia de cada uma dessas esferas de validez, demonstrando que nelas ainda vigoram o interesse e a vontades de poder. Por isso, no campo das ciências sociais ele identifica a racionalidade funcionalista como principal matriz de uma perniciosa ideologia na teoria, que se sustenta a partir da dissolução da diferença entre a esfera da validez e a pura faticidade, determinada nomologicamente ao modo das ciências naturais.

Como assinalamos anteriormente, Habermas vê-se obrigado a incluir nesta ideologia funcionalista todas as filosofias sociais que, ao radicalizar a crítica do caráter autodestrutivo da razão, terminam desprezando seu desdobramento interno em esferas de validez simbolicamente constituídas e esferas institucionais de expectativas normativas. Assim, resulta claro que este desdobramento não se pode transformar em uma mera petição de princípios. Esse tipo de argumentação reduziria por completo a teoria crítica da sociedade a uma ética (do discurso), que é algo que Habermas quer evitar a todo custo (daí 
sua diferença com Apel). E é neste ponto que o conceito de esfera pública cumpre um papel fundamental ${ }^{79}$, como o fará logo na teoria de Honneth. A realidade histórica da esfera pública liberal representa o melhor modelo de um desdobramento claro e pleno entre as expectativas normativas institucionalizadas (da economia e da política) e a esfera na qual se delibera acerca das pretensões de validez das normas (que deveriam servir para regular a economia e a política). A teoria da racionalização social serve a Habermas para determinar a esfera pública liberal como o ponto de máximo progresso do desenvolvimento cultural, constituindo-se, portanto, em um modelo estrutural do conceito de cultura com o qual a teoria crítica tem que trabalhar. Se recorrermos a uma famosa expressão, pronunciada em seu momento no marco de outra teoria da evolução social, poderíamos afirmar que assim como "a anatomia do homem explica a anatomia do macaco e não o contrário", para Habermas, a estrutura e o lugar social da esfera pública explica a estrutura e o lugar da cultura em todas as outras formações sociais. E é este passo decisivo, que constitui a dimensão crítica da teoria habermasiana, aquele que a teoria da cultura de Adorno não pode dar.

Quando completa sua teoria da sociedade, Habermas deduz historicamente do conceito de esfera pública um limite objetivo ao avanço incessante do poder que se encarna na racionalidade administrativa; e, por outro lado, um critério normativo que lhe serve para fundamentar a dimensão crítica da teoria da sociedade, sem que esta tenha que assumir um caráter - ao menos isso pretende Habermas - "utópico", "ideal" ou puramente "ético". O tipo de distância que a esfera pública liberal consegue instalar com respeito às normas e ao funcionamento institucionalizado da economia e da política constitui, para Habermas, o material empírico que lhe permite dar seus grandes passos no campo da produção de teoria. É essa realidade empírica a que sustenta a distinção essencial que funda a rejeição do legado de Adorno e Horkheimer e realiza a mudança de paradigma, ou seja, é essa realidade empírica a que permite a Habermas deduzir historicamente a diferença categorial entre a ação social teleologicamente orientada e a ação social orientada para a comunicação e o entendimento recíproco. Sem a existência do conceito de esfera pública, essa distinção

\footnotetext{
${ }^{79}$ Cfr., Habermas (1987b): 452 e ss.
} 
seria completamente impossível em termos teóricos (que aspirem a uma "pretensão de verdade" e não exclusivamente a uma "pretensão de retidão" ético-moral).

A realidade da esfera pública é a que inscreve efetivamente uma dimensão reflexiva e dialógica na economia e na política estatal, que não existiria sem a distância e a mediação desta terceira esfera em que se constitui a cultura. Quando Habermas critica as "unilateralidades" do conceito de mundo administrado e propõe a Teoria da Ação Comunicativa como marco teórico superador, orientado a pensar os efeitos patológicos colaterais do processo de racionalização, apresenta explicitamente, frente a eles, a esfera pública liberal como sua antítese efetiva. Vale dizer, se por um lado ele reconhece, junto com Weber, Adorno e Horkheimer, que a racionalidade administrativa que organiza a economia capitalista e o Estado burguês implica uma forma de poder sobre os homens que é capaz de transformar-se no "modelo de toda servidão do futuro", ele se propõe demonstrar que, a partir da existência autônoma da esfera pública, essa racionalidade vê-se suspensa e interferida por outra racionalidade, que não procura a eficácia das relações objetivas, mas o acordo livre e o entendimento recíproco entre os sujeitos que participam das práticas sociais econômicas e políticas. Graças à esfera pública liberal, a economia e a política são enfrentadas por uma lógica de integração social diferente que, necessariamente, limita os efeitos expansivos de sua própria racionalidade imanente (isto é, a racionalidade administrativa ou burocrática) e transforma internamente sua estrutura, de tal modo que já não poderá ser pensada exclusivamente em termos de relações de dominação e de relações de produção. A ação comunicativa é o nome dessa outra lógica de integração social, que existe em toda interação social mediada por meio da linguagem, mas que logo assume um corpo próprio no centro da esfera pública liberal. Este é o fundamento empírico da ampliação teórica que Habermas reclama veementemente em distintos campos, com distintos argumentos. E é este desdobramento categorial o que a racionalidade funcionalista se nega a aceitar. O caráter ideológico desta racionalidade no campo das ciências sociais expressa-se no reconhecimento unilateral de um único modelo de integração social, o qual depende exclusivamente de meios de controle, poder e dinheiro, desprezando a especificidade ontológica (ou quase ontológica) da integração social que se estrutura graças à utilização de meios de comunicação. Esta redução no campo da teoria coincide, no campo da prática, com a "colonização do mundo da vida", que a perspectiva habermasiana 
denuncia como o resultado principal das novas formas de dominação social. ${ }^{80}$ Daí o caráter ideológico da racionalidade funcionalista; por um lado, pela opacidade que introduz no plano teórico e, por outro, pela legitimação que - consciente ou inconscientemente - acaba realizando no plano da práxis das novas formas de controle social.

Mas o conceito de esfera pública não só serve a Habermas para criticar o diagnóstico e a teoria que sustenta o conceito de mundo administrado. Esse conceito também lhe permite pronunciar-se contra a necessidade de recorrer à "estetização da teoria" para formular a dimensão crítica da teoria da sociedade; ou seja, o conceito de esfera pública vai permitir também a Habermas transcender os limites dogmáticos que pretendem encerrar o pensamento teórico dentro do terreno do meramente explicativo, sem ter que dar o salto para a irracionalidade. Na esfera pública liberal (que pode discorrer acerca de diversos temas) vigora, segundo Habermas, um tipo de justificação das pretensões de validez que exige, de parte dos sujeitos que intervêm nela, reciprocidade e igualdade no direito ao uso da palavra, o privilégio da argumentação por cima de outras modalidades enunciativas, a aceitação irrestrita da crítica e um tipo de consenso que só surge como resultado, nunca como pressuposto, do intercâmbio simbólico. Nesta trama deliberativa, instável e polêmica, Habermas descobre um substituto pós-metafísico do "entendimento comum" kantiano. Ele considera que se pode extrair daí um novo modelo social de verdade, que não precisa recorrer a formas pré-modernas de pensamento (como aquelas que imperam nas sociedades primitivas e com as quais a arte encontra-se indissoluvelmente unida) para estabelecer um horizonte normativo que permita criticar os efeitos patológicos da racionalização no campo da teoria.

Com um enfoque diferente, a teoria do reconhecimento de Honneth procede da mesma maneira que Habermas no que diz respeito à relevância teórica atribuída ao conceito de esfera pública. Neste caso, o que se reconstrói a partir da ideia de esfera pública já não é o "entendimento livre de coações" de um modelo de racionalidade, mas um tipo de "reconhecimento da dignidade" dos homens capaz de garantir um modelo de Estado. Da opacidade da cultura moderna, Honneth extrai uma filosofia moral que seria capaz de se desempenhar como matriz da teoria social crítica. No centro dessa filosofia moral, a

\footnotetext{
${ }^{80}$ Cfr., Habermas (1987b): 479-492 e 554-562.
} 
reformulação da categoria kantiana de "dignidade" esta perspectiva, todas as teorias sociais modernas que se quiseram conceber como expressão legítima dos interesses pela emancipação pensaram - de um modo mais ou menos rudimentar - a luta pelo reconhecimento social como o nervo do progresso social. Para estas teorias, que a posição de Honneth procura retomar em um maior nível de cientificidade, a busca do reconhecimento da própria dignidade é o motivo central que leva os homens à luta social e o principal articulador do sentido dos conflitos sociais. ${ }^{82} \mathrm{E}$ é, novamente, a esfera pública liberal que serve como suporte histórico para explicitar a estrutura destas relações de reconhecimento. Certamente, ao transformar a ideia kantiana de "dignidade" mediante uma teoria do poder mais realista - no sentido de Weber -, esta categoria conserva, na teoria de Honneth, seu papel como horizonte crítico das formas de sociabilidade efetivamente existentes; mas o faz a partir de um estatuto sócio-histórico que já admite a fundamentação da metafísica dos costumes. Em um sentido muito próximo àquele de Habermas, a luta pelo reconhecimento da própria dignidade assume, num

\footnotetext{
${ }^{81}$ A clássica definição moderna da categoria de "dignidade" que oferece a filosofia moral de Kant articula-se perfeitamente com a compreensão do fenômeno de reconhecimento intersubjetivo que Honneth tenta reconstruir. A definição kantiana inclui as duas determinações essenciais desse tipo de reconhecimento, isto é, a singularidade e a autonomia do sujeito, e as associa para opô-las ao caráter ideologicamente abstrato da racionalidade instrumental: "Im Reiche der Zwecke hat alles entweder einen Preis, oder eine Würde. Was einen Preis hat, an dessen Stelle kann auch etwas anderes, als Äquivalent, gesetzt werden; was dagegen über allen Preis erhaben ist, mithin kein Äquivalent verstattet, das hat eine Würde. Was sich auf die allgemeinen menschlichen Neigungen und Bedürfnisse bezieht, hat einen Marktpreis; das, was, auch ohne ein Bedürfnis vorauszusetzen, einem gewissen Geschmacke, d.i. einem Wohlgefallen am bloßen zwecklosen Spiel unserer Gemütskräfte, gemäß ist, einen Affektionspreis; das aber, was die Bedingung ausmacht, unter der allein etwas Zweck an sich selbst sein kann, hat nicht bloß einen relativen Wert, d.i. einen Preis, sondern einen innern Wert, d.i. Würde." Kant, I., Grundlegung zur Metaphysik der Sitten, Suhrkamp, Frankfurt am Main, p. 88.

82 "Marx, Sorel e Sartre, os três representantes da tradição teórica há pouco exposta, detiveram-se igualmente num nível pré-científico, à experiência de que a autocompreensão dos movimentos sociais de sua época estava atravessada fortemente pelo potencial semântico do vocabulário conceitual do reconhecimento: para Marx, que acompanhou bem de perto os primeiros ensaios de organização da classe operária, estava fora de questão que as finalidades amplas do movimento emergente pudessem sintetizarse no conceito de "dignidade"; Sorel, um companheiro teórico do sindicalismo Francês, empregou à sua vida a categoria de "honra", soando a conservadorismo, para conferir expressão ao conteúdo moral das exigências políticas do movimento operário; e o Sartre dos anos 1950, finalmente, deparou no famoso livro de Franz Fanon até mesmo um panfleto anticolonialista, que procurava interpretar as experiências dos negros oprimidos da África recorrendo diretamente à doutrina de reconhecimento de Hegel." Honneth (2003): 253.
} 
contexto pós-metafísico, as pretensões políticomorais do conceito kantiano de "dignidade", em termos que a transformam no núcleo conceitual adequado para realizar uma fundamentação crítica da teoria da sociedade.

A textura intersubjetiva da esfera pública liberal é convocada, no caso de Honneth, para explicitar um tipo de unidade entre os homens que também depende do desdobramento interno entre validez e faticidade, mas considerado agora do ponto de vista da dialética do poder na modernidade. Assim como Habermas reconstrói o desdobramento da razão moderna em pretensões de validez e expectativas normativas institucionalizadas, Honneth realizará uma operação idêntica com respeito às relações de poder. Neste ponto, sua oposição ao conceito unilateral de poder de Adorno e Horkheimer estende-se também à posição de Foucault: eles não teriam sido capazes de compreender, por um lado, o desdobramento interno e a tensão que existe na política moderna entre as instituições $e$ práticas estatais, e, por outro, a esfera pública da política. As primeiras podem ser pensadas seguindo uma lógica teórica funcionalista. Mas as relações da esfera pública com aquelas instituições só podem ser pensadas sob essa lógica a partir de uma perspectiva ideológica, que reduz os problemas da constituição da validez das normas ao registro único da ação estratégica e das relações de dominação. Ao não tomar em consideração esta distinção, Adorno e Foucault entendem que "a integração social característica das sociedades modernas constitui-se por meio da conexão institucional dos distintos aparelhos disciplinadores" (Honneth, 1997: 179), transformando-se esta posição num obstáculo para conceber o caráter contraditório do poder na modernidade. Se o fizessem, teriam que aceitar que "cada estabilização das relações de poder pressupõe a interrupção da luta na forma de um acordo motivado normativamente ou de um compromisso mútuo alcançado pragmaticamente" (Honneth, 1997: 174). E esses acordos, essas formas de integração que surgem como resultado da luta social, não são outra coisa senão as relações de reconhecimento intersubjetivo que Honneth tenta recuperar para a teoria crítica.

Sob esta perspectiva, os acordos normativos cristalizados nas leis sancionadas pelo Estado e aqueles que regulam as diversas instituições econômicas não deveriam ser considerados exclusivamente como "ilusões" ou "instrumentos" que funcionariam ao serviço da dominação. ${ }^{83}$ A teoria crítica deveria ser capaz de interpretar essa trama

${ }^{83}$ Cfr., Honneth (1997): 162-170. 
intersubjetiva num sentido duplo: a) como resultado de uma luta na qual todos os sujeitos participantes são capazes de exercer posições de poder; e b) como marco que permite a formação de novas relações de reconhecimento recíproco, que enriquecem as estruturas normativas com direitos cada vez mais inclusivos e avançados moralmente. A dialética do poder, que Honneth reconstrói com um marcado viés evolucionista, culmina numa dinâmica sequencial das distintas formas de reconhecimento intersubjetivo. Esta sequência começa com a unidade que produz o resultado da primeira luta pelo reconhecimento; segue com a aparição de uma lesão (moral), com a experiência de um sujeito que vive a vigência dessa primeira estrutura de reconhecimento como um dano que lhe é causado; o qual motiva a ação e a luta pelo reconhecimento dessa subjetividade lesada, que se orienta no sentido da transformação e da criação de novas estruturas normativas, e assim por diante. No lugar mais elevado dessa sequência encontra-se a categoria de "dignidade", a qual, não por acaso, vigora nas sociedades cujas instituições estatais e econômicas veem-se obrigadas a conviver com uma dimensão cultural que se estrutura sob a forma de uma esfera pública autônoma. ${ }^{84}$ A teoria crítica deveria apoiar-se, segundo Honneth, nas pretensões de validez

${ }^{84}$ Uma síntese da sequência lógica e histórica contida na teoria do reconhecimento pode ser encontrada em: Honneth (2003): 155 e ss. O gráfico abaixo mostra o funcionamento da totalidade de suas categorias:

\begin{tabular}{|l|l|l|l|}
\hline \multicolumn{4}{|c|}{ Estrutura das relações sociais de reconhecimento } \\
\hline $\begin{array}{l}\text { Modos de } \\
\text { reconhecimento }\end{array}$ & Dedicação emotiva & Respeito cognitivo & Estima social \\
\hline $\begin{array}{l}\text { Dimensões da } \\
\text { personalidade }\end{array}$ & $\begin{array}{l}\text { Natureza carencial e } \\
\text { afetiva }\end{array}$ & Imputabilidade moral & $\begin{array}{l}\text { Capacidades e } \\
\text { propriedades }\end{array}$ \\
\hline $\begin{array}{l}\text { Formas de } \\
\text { reconhecimento }\end{array}$ & $\begin{array}{l}\text { Relações primárias } \\
\text { (amor, amizade) }\end{array}$ & $\begin{array}{l}\text { Relações jurídicas } \\
\text { (direitos) }\end{array}$ & $\begin{array}{l}\text { Comunidade de valores } \\
\text { (solidariedade) }\end{array}$ \\
\hline Potencial evolutivo & Autoconfiança & $\begin{array}{l}\text { Generalização, } \\
\text { Materialização }\end{array}$ & $\begin{array}{l}\text { Individualização, } \\
\text { igualização }\end{array}$ \\
\hline Autorrelação prática & Maus tratos e violação & $\begin{array}{l}\text { Privação de direitos e } \\
\text { exclusão }\end{array}$ & Degradação e ofensa \\
\hline Formas de desrespeito & Autoestima \\
\hline
\end{tabular}


que se organizam neste ápice da sequência progressiva da dialética do reconhecimento para, a partir daí, estabelecer uma crítica social - fundada no próprio desenvolvimento histórico - das formas de sociabilidade que danificam ou não respeitam a dignidade de todos os homens.

O lugar que a cultura ocupa nas críticas que Habermas e Honneth dirigem à teoria da sociedade da "primeira geração da Escola de Frankfurt" resultou ser central. E isto pode ser constatado, como acabamos de mostrar, não só no desenvolvimento dessas críticas, mas também - e talvez fundamentalmente - no modelo teórico alternativo que propõem. Como vimos nos capítulos precedentes, a denúncia das unilateralidades do diagnóstico de Adorno, que comprova a existência de uma opacidade radical na cultura da modernidade tardia, suporta uma revalorização teórica do conceito de esfera pública. Este conceito serve para reconstruir teoricamente o espaço histórico das práticas e das interações sociais que medeiam, regulam e interferem na reprodução puramente "administrativa" da economia e do Estado, oferecendo assim esse novo conceito de cultura que a teoria crítica estava procurando desde os primeiros textos de Horkheimer. A dificuldade que Adorno não pôde enfrentar consiste em que o estatuto da esfera pública não é nem ideal, nem material; não pode ser reduzido ao plano da faticidade das relações sociais, mas tampouco pode ser reconduzido para a mera vontade, as opiniões ou os valores dos indivíduos e dos grupos sociais. Na condição de mediação efetiva da economia e do Estado, a esfera pública das sociedades modernas avançadas institui, com "claridade e distinção", a separação entre a faticidade e a validez da ordem social que Adorno não soube (ou não quis) pensar. A partir dessa separação, Habermas e Honneth deduzem o duplo caráter da teoria social, que deve incluir necessariamente num mesmo corpo teórico a perspectiva do sistema e a perspectiva do mundo da vida. De nossa parte, devemos destacar de novo o fato de que, sem a realidade histórica e o conceito de esfera pública, esse requisito só poderia cumprir-se a partir de uma posição ética, mas muito dificilmente a partir de uma posição teórica.

\begin{tabular}{|l|l|l|l|}
\hline $\begin{array}{l}\text { Componentes } \\
\text { ameaçados da } \\
\text { personalidade }\end{array}$ & Integridade física & Integridade social & "Honra", dignidade \\
\hline
\end{tabular}


A estratégia de Habermas e Honneth na polêmica com Adorno e Horkheimer tornase clara quando se compreende cabalmente seu recurso ao conceito de esfera pública e a importância que lhe atribuem. Com este conceito, eles dão forma definitiva à ideia de que o objetivo central da teoria crítica deve consistir em reconstruir, explicitar e desenvolver o potencial evolutivo das sociedades modernas. O segredo desta ideia desvenda-se agora abertamente: a cultura moderna. Diferentemente do que acontece na economia e na esfera político-estatal modernas, as quais tendem a estruturar-se univocamente segundo os lineamentos da "racionalidade administrativa", a cultura moderna aparece na interpretação de Habermas e Honneth como depositária do antídoto contra o poder destrutivo do capitalismo. Ela resguardaria o interesse pela emancipação e o interesse pela verdade, na forma de uma cultura política e de uma cultura científico-filosófica autônomas em relação ao alcance e à eficácia da "racionalidade administrativa". Quando Habermas e Honneth reconstroem este potencial evolutivo, fazem-no reencontrando a vigência de Kant, além da filosofia do sujeito monológico, na comunicação livre de coações que facilita o entendimento comum e no reconhecimento intersubjetivo que garante o respeito da dignidade dos indivíduos socializados. Entendimento comum e respeito da dignidade humana são as chaves secretas da cultura moderna que a teoria crítica deveria ser capaz de decifrar numa perspectiva histórica "empiricamente controlada". Sua existência na modernidade não é, certamente, um fato consumado, mas coincide com as pretensões de validez que vigoram no frágil espaço social da esfera pública, constantemente assediada pela ameaça "colonizadora" da racionalidade administrativa. Apesar desta ameaça, a aposta teórica de Habermas e Honneth é muito clara: reconstruir, a partir da modernidade cultural, as pretensões de validez imanentes às próprias sociedades modernas, que sirvam para julgar criticamente a configuração efetiva e o desenvolvimento das distintas sociedades.

Em face do conjunto desta revisão teórica, surge imediatamente uma pergunta: não se assemelha a estratégia crítica de Habermas e Honneth a utilização ideológica do conceito de cultura - denunciada oportunamente por Adorno -, que consiste em atribuir à cultura moderna uma função apaziguadora da realidade efetiva do poder destrutivo do capitalismo? Se assim for, e, se quisermos evitar que a filosofia cumpra com esse papel, ainda teríamos que enfrentar o dilema que colocaram Habermas e Honneth, em relação às condições de 
possibilidade para a teoria crítica no contexto de um diagnóstico radical acerca das catástrofes do mundo moderno.

O primeiro passo neste caminho tem que ser necessariamente crítico. Crítico da interpretação da cultura que se estrutura a partir do conceito de esfera pública e crítico, também, do uso que dele fazem Habermas e Honneth. O primeiro indício que deveria motivar ambas críticas é um elemento de total atualidade. Pelo modo como organizam "a dimensão crítica" de seus respectivos modelos teóricos, para os dois autores as lesões, os danos e a violência no capitalismo tardio só podem ser concebidos como aquilo que danifica, opõe-se ou "coloniza" a esfera de validez do entendimento comunicativo e do reconhecimento moral entre os homens. Isso permite, sem dúvidas, a possibilidade de contar com ferramentas teóricas que conseguem inserir-se ativamente nos debates políticos e filosóficos contemporâneos, estabelecendo uma espécie de dique de contenção contra fenômenos tão regressivos como a burocratização da ciência, a privatização da política, a persistência da desigualdade frente à lei e os atos discriminatórios que impulsionam perversamente muitos dos marcos normativos institucionalizados. O único - e daí a importância deste assinalamento - que esta estratégia teórica não pode pensar é a transformação do próprio entendimento comunicativo e do reconhecimento moral em instrumentos da violência do capitalismo tardio. ${ }^{85}$ Segundo nosso entender, isto é algo que a crítica cultural de Adorno não só permite pensar, mas também assume como uma das tarefas fundamentais para a teoria crítica da sociedade. ${ }^{86}$

Vista sob este prisma, a estratégia que compartilham Habermas e Honneth poderia ser interpretada como uma ideologia da intersubjetividade, que resolve nos "tipos ideais" que têm sua origem em relações intersubjetivas, os extremos da reflexão crítica da "primeira geração da Escola de Frankfurt". O que aparece como um salto teórico e uma superação de um velho paradigma, em realidade, não é mais do que um esforço por

\footnotetext{
${ }^{85}$ Ao analisar a matriz ideológica que legitimou a primeira guerra do Golfo e a guerra da Sérvia, Paulo Arantes fez uma inquietante denúncia da confluência que esta realizou entre a ordem jurídico-política cosmopolita, a guerra segura e o estado de sítio mundial. Em ambos casos, tanto Habermas quanto Honneth possibilitaram essa prática legitimadora a partir de seus respectivos paradigmas teóricos. Ver: "Notícias de uma guerra cosmopolita", in: Extinção, ed. Boitempo, São Paulo, 2007.

${ }^{86}$ Frederic Jameson justifica deste modo a atualidade teórica de Adorno. Ver, Jameson, F, Late Marxism. Adorno: or, The persistence of the dialectic, Verso, Londres, 2007.
} 
neutralizar o tratamento dialético de uma série de fenômenos contraditórios, aos quais a partir de agora aplica-se a sabedoria aristotélica do justo meio. Quer dizer, entre o diagnóstico da dominação total e a apologia da liberdade, constrói-se a teoria que diagnostica uma "tensão permanente" entre o sistema e o mundo da vida; entre a coisificação completa da razão e sua autonomia fundada numa metafísica transcendental, aparece a razão procedimental situada em diversos contextos pragmáticos; entre a normatividade como instrumento do poder e a normatividade como garantia da autodeterminação moral, postula-se o reconhecimento como um acordo moral conseguido por meio do conflito social. A intersubjetividade funciona, desta maneira, como o suporte de uma espécie de dedução transcendental, que se irradia sobre os antigos problemas da crítica da modernidade pondo ordem, hierarquizando e resolvendo as diferenças das partes em conflito. Dese modo, não seria esta estratégia, que resolve os extremos de uma contradição (objetiva) em seu justo meio, a tentação filosófica contra a qual nos adverte todo o trabalho conceitual da Dialética Negativa? Os problemas que suscita a tentativa de alcançar uma fundamentação crítica das ciências sociais poderiam ser abordados a partir dessa estratégia de depuração conceitual, que elimina os extremos para alcançar as "formas autônomas" de entendimento e reconhecimento que teriam que reger numa sociedade emancipada?

A resposta mais conhecida de Adorno a esta questão se encontra num dos aforismos mais importantes de Mínima Moralia: "Es gibt kein richtiges Leben im falschen" (MM: 43). Evidentemente, esta máxima afeta não só o sujeito moral, mas também o sujeito de conhecimento. Mas apenas ao se pronunciar este enunciado aparecem todos os fantasmas: naturalismo, funcionalismo, cinismo epistemológico e moral. E frente a estes fantasmas do discurso filosófico da modernidade, a relação entre normatividade e intersubjetividade que defendem Habermas e Honneth aparece sempre como a melhor resposta, no mínimo porque apresenta à teoria crítica um caminho na penumbra. Deste modo, consegue-se o vínculo com o núcleo conflitivo da práxis social e a crítica imanente aos processos de fundamentação da razão. O problema, tal como o assinalamos, é que a teoria crítica permanece soldada desta maneira a uma dupla experiência fundadora, da qual dificilmente pode desconfiar: a indignação moral como código político e a controvérsia discursiva como código cognitivo. Tudo aquilo que exceda esses limites é reintegrado à opacidade do 
mundo e à irracionalidade da cultura, mas agora sem nenhuma preparação teórica para enfrentá-la e compreendê-la. A pergunta que o aforismo de Adorno dirigiria a este resultado é relativamente simples: podemos estabelecer uma equivalência legítima entre os "condenados da terra" e os indignados da esfera pública? Ou, no outro caso, é legítimo identificar a oposição discursiva na esfera pública que discute a falsidade de uma opinião, um argumento ou um enunciado em geral, com o esforço pela verdade na modernidade tardia? Como se deduz facilmente, o que torna impossível esta identidade não pode ser interpretado meramente como um problema de diagnóstico, já que ao ter elevado a conceito as propriedades emancipatórias e racionais da esfera pública, Habermas e Honneth acabaram ocultando essa não-identidade na própria matriz da teoria crítica. Estes são o mérito e o limite da relação entre intersubjetividade e normatividade a que chegam Habermas e Honneth logo depois da crítica ao conceito de cultura da "primeira geração da Escola de Frankfurt”, isto é, logo depois de criticar Adorno. Poderíamos denominar ideologia frankfurtiana a toda esta operação de leitura e à elaboração do novo marco "intersubjetivista" da teoria crítica.

O que é necessário indagar ainda é se o conceito de cultura (e o conjunto da filosofia social) de Adorno carece efetivamente, tal como Habermas e Honneth supõem, de um modelo alternativo para ensaiar uma fundamentação crítica das ciências sociais. Uma passagem enigmática da Dialética Negativa nos servirá de ponto de partida para organizar nossa resposta, que desenvolveremos nos sucessivos capítulos deste trabalho. Depois de dissecar em todos seus pontos conflitivos a filosofia moral kantiana, Adorno chega a uma conclusão muito similar à que sugeria o fragmento de Mínima Moralia: "Na sociedade socializada (vergesellschafteten Gesellschaft) todos os indivíduos são incapazes da moral que se lhes exige socialmente, a qual, em realidade, só pode existir numa sociedade liberada" (ND: 294). A diferença é que, nesta ocasião, Adorno não se limita a assinalar o caráter ideológico que podem assumir as pretensões de validez modernas, ao confrontá-las com a estrutura social que as produz. Evitando atribuir dogmaticamente um estatuto transcendental à esfera das pretensões de validez normativas, dá um segundo passo e reinscreve a normatividade numa situação paradoxal: "Até então, para o indivíduo não permanece (anbleiben) disponível outra moralidade senão a absolutamente desprezada pela ética kantiana quando concede inclinação (Neigung) aos animais, mas não respeito 
(Achtung): a de tentar viver de modo que se possa acreditar ter sido um bom animal" ( $d a \beta$ man glauben darf, ein gutes Tier gewesen zu sein, Ibíd.).

Que significado pode adquirir a expressão "bom animal" no contexto de nossa discussão? Qual é seu alcance teórico dentro da distinção entre ciências factuais e ciências normativas? A nosso entender, a relação entre faticidade e normatividade para a qual assinala esta passagem excede o terreno da filosofia moral e se prolonga para o núcleo central de nosso interesse filosófico. Com o aparente oxímoro do "bom animal", a Dialética Negativa determina a faticidade e a normatividade como os pontos extremos de uma relação contraditória que Adorno denominou dialética da liberdade ${ }^{87}$, marcando deste modo um caminho fecundo para a discussão filosófica referida na lógica das ciências sociais.

Já num primeiro nível de análise podemos perceber as alternativas que Adorno está rejeitando com esta singular construção, que pretende tornar compreensíveis as relações sociais em um plano diferente do proposto tanto pela racionalidade funcionalista quanto pela racionalidade crítico-dualista. A expressão "bom animal" problematiza com seu caráter paradoxal tanto a redução das distintas esferas de validez normativas ao plano da pura imanência na faticidade, quanto a fixação da cisão entre ambas. O gute Tier de Adorno, cuja "moralidade" é considerada como "factível" para uma sociedade não liberada como a nossa, não é nem um capitalista animal, nem um bom homem; não representa nem a pura potência da vida, que destitui a normatividade de toda especificidade, nem a dignidade pura do sujeito, que consagra a normatividade num plano ontológico específico.

\footnotetext{
87 "Seit dem siebzehnten Jahrhundert hatte die große Philosophie Freiheit als ihr eigentümlichstes Interesse bestimmt; unterm unausdrücklichen Mandat der bürgerlichen Klasse, sie durchsichtig zu begründen. Jenes Interesse jedoch ist in sich antagonistisch. Es geht gegen die alte Unterdrückung und befördert die neue, welche im rationalen Prinzip selbst steckt. Gesucht wird eine gemeinsame Formel für Freiheit und Unterdrückung: jene wird an die Rationalität zediert, die sie einschränkt, und von der Empirie entfernt, in der man sie gar nicht verwirklicht sehen will. [...]Bei Kant bildet Antinomik, bei Hegel Dialektik der Freiheit ein wesentliches philosophisches Moment; nach ihnen ward zumindest die akademische Philosophie vereidigt aufs Idol eines Höhenreichs über der Empirie. Die intelligible Freiheit der Individuen wird gepriesen, damit man die empirischen hemmungsloser zur Verantwortung ziehen, sie mit der Aussicht auf metaphysisch gerechtfertigte Strafe besser an der Kandare halten kann. Die Allianz von Freiheitslehre und repressiver Praxis entfernt die Philosophie immer weiter von genuiner Einsicht in Freiheit und Unfreiheit der Lebendigen. Sie nähert sich, anachronistisch, jener faden Erbaulichkeit, die Hegel als Elend der Philosophie diagnostizierte." Adorno (ND): 213-214, (destaque próprio).
} 
De maneira diferente a Habermas, que só considera ideológica a dissolução da diferença entre faticidade e validez, para Adorno também a rígida fixação dessa diferença deve ser considerada como uma das principais posições filosóficas que tentam fundamentar em termos ideológicos o enfoque básico das ciências sociais. Dissolução da diferença entre faticidade e validez, e fixação dessa diferença são, para Adorno, as duas faces da mesma moeda; essas posições só podem ser criticadas em sua estrutura conceitual e em seu funcionamento ideológico no centro da teoria da sociedade ao expor sua dupla determinação como momentos de uma mesma análise dialética, que impede que cada uma delas possa estabelecer-se como um princípio independente. Não é casualidade, portanto, a dialética da liberdade ocupar o primeiro lugar entre os modelos de dialética negativa.

Quando a posição naturalista e a posição trascendentalista são confrontadas reciprocamente, aparece com um relevo mais nítido o caráter ideológico de cada uma delas. A primeira mostra sua falsidade ao não ser capaz de pensar seriamente aquilo que não coincide com a determinação cientificista da faticidade, quer dizer, a existência do nãoidêntico com a realidade organizada em torno da ação instrumental, a racionalidade administrativa e as relações de dominação. Este é o tipo de racionalidade das ciências sociais que a racionalidade comunicativa permite criticar teoricamente. Mas ao enfrentar a racionalidade comunicativa com o outro extremo desta relação, aparece o caráter repressivo que assumem na modernidade tardia as categorias de reconhecimento moral e entendimento comunicativo. Na condição de cúmplices involuntários de uma normatividade frente à qual os indivíduos são estruturalmente incapazes, o rigor de sua determinação formal e transcendental termina impondo, sob o rótulo da violência jurídica legítima, uma modalidade do poder ao qual a teoria crítica deveria resistir. Deste modo, a racionalidade comunicativa transforma-se num obstáculo da racionalidade socialmente possível (ou da racionalidade que "permanece" neste mundo).

Se a primeira crítica, a crítica da racionalidade funcionalista, é de certa forma a mais esperada dentro do contexto da filosofia social frankfurtiana, a segunda surpreende pelo modo como a realiza Adorno. No afastado da Dialética negativa que descreve a dialética da liberdade, Adorno não só critica a racionalidade prática kantiana (que logo encarnarão, cada uma à sua maneira, a racionalidade comunicativa e a dialética do reconhecimento moral) por pretender a existência de uma ordem moral que não se pode reger socialmente. Ele 
também justifica essa crítica ao determinar a incapacidade de qualquer modelo formal de racionalidade para situar a normatividade, sem que esta assuma uma posição repressiva e tutelar da liberdade faticamente possível para o indivíduo. O que surpreende é que, no centro desta crítica, Adorno não considera a racionalidade moral formalista (dentro da qual devem ser incorporados os conceitos de entendimento comunicativo e reconhecimento moral) como uma ilusão que obstrui a plena expansão da "vontade de poder", mas sim como um mecanismo que inibe, no indivíduo e nas práticas sociais, as forças que fariam possível a própria moralidade.

As ressonâncias desta consequência da dialética da liberdade no terreno da lógica das ciências sociais são imediatas. Seguindo a linha de articulação da polêmica que riscamos até aqui, poderíamos afirmar que a singularidade da dialética negativa no campo da teoria da sociedade consiste em indicar o caminho para conhecer as instâncias de mediação e autonomia frente aos imperativos da economia e do Estado, quer dizer, aquilo que Honneth denominou "domínios pré-estatais de ação", sem ter que interpretá-los necessariamente como "convicções normativas" e "deliberações individuais orientadas para o prosseguimento de um fim" (Honneth, 1997: 76). Com esta aposta teórica suspeita-se, tal como o fez explicitamente Adorno no campo da filosofia prática, da interpretação formalista que realiza tanto a teoria da ação comunicativa quanto a teoria do reconhecimento. Ambas podem aparecer, nesta chave de leitura, como tentativas abstratas de situar a normatividade no plano teórico, que acabam invisibilizando e desconhecendo o que se propunham conhecer como teorias críticas, isto é, as variadas formas de racionalidade e resistência ao poder que permanecem abertas para os homens (quando não são enfrentados rigidamente com o código moral e cognitivo da modernidade cultural). A teoria crítica da sociedade, então, deixaria de operar por intermédio da formalização das pretensões de validez modernas. Mas não o faria denunciando sua oposição ao princípio abstrato "da vida" ou à "vontade de poder", senão demonstrando que esses tipos de pretensões de validez possuem, na estrutura interna da racionalidade a que aspiram, elementos que reprimem a constituição da autonomia socialmente possível para a moral, a ciência e a arte. Nós tentaremos reconstruir, pelo menos em termos preliminares, os passos subsequentes desta reformulação teórica, a partir de uma reconsideração do papel da arte no 
conceito adorniano de cultura (Parte II), para logo tentar precisar nossas conclusões ao respeito. 


\section{Segunda parte \\ O olhar de Apolo}

A arte como momento negativo da cultura 


\section{Capítulo 3: O duplo sentido da técnica \\ Adorno e a dialética da modernidade cultural}

Contra o que podiam pressupor em seu momento as análises "científicas" de Habermas e de uma ampla tradição sociológica de orientação empirista, diferentes transformações recentes do campo cultural tornaram evidente a enorme atualidade da crítica que Adorno e Horkheimer propuseram com o conceito de indústria cultural. A consolidação de empresas culturais que já conseguem operar no nível de monopólios globais de informação e entretenimento, a drástica transformação dos objetos culturais em puros valores de troca de uma economia cada vez mais "estetizada", a fusão da cultura com a técnica e a dissolução completa da arte e da política no espetáculo, são só alguns dos motivos desta atualidade que foi observada com interesse por diversos autores. ${ }^{88}$ Entretanto, esta estranha persistência "fora de tempo" do pensamento frankfurtiano da "primeira geração" vê-se velada pela imagem, também persistente, que os apresenta como "pensadores elitistas", que se distinguem essencialmente pela saudade de uma autenticidade cultural que a cultura de massas teria liquidado. Por diversos motivos, a imagem do "mandarinismo cultural" de Adorno e Horkheimer bloqueia qualquer pensamento que procure retomar seu potencial crítico para a atualidade. Mobilizada pela sociologia da cultura que se tornou hegemônica ${ }^{89}$ e pelo pragmatismo filosófico que defende - por princípio - o existente frente a tudo o que tiver cheiro de metafísica, essa imagem (na qual

\footnotetext{
${ }^{88}$ Ver Lash, S., "Wir leben im Zeitalter der globalen Kulturindustrie", in: Die zeit/10, Feuilleton, Berlin, 26 feb, 1998; Hansen, M., "Mass culture as hieroglyphic writing: adorno, derrida, kracauer", in: New German Critique № 56 (Spring/Summer 1992); Koch, G., "Mimesis und Bilderverbot in Adornos Ästhetik. Ästhetische Dauer als Revolte gegen den Tod", in: Babylon № 6, pp. 36-45, 1989; Jameson, F., Late marxism: Adorno: or, the persistence of the dialectic, Londres, Verso, 2007; Duarte, R., Teoria crítica da indústria cultural, ed. Humanitas-UFMG, Belo Horizonte, 2003.

${ }^{89}$ Ao caraterizar a teoria da cultura de Adorno, Pierre Bourdieu considerou suas análises como prototípicas da "arrogance du théoricien qui refuse de se salir les mains dans la cuisine de l'empirie et qui reste trop viscéralement attaché aux valeurs et aux profits de la Culture pour être en mesure d'en faire un objet de science", Bourdieu, P., La distinction, Minuit, Paris, 1979, p. 598. É sabido que para Bourdieu a teoria estética adorniana acerca da "arte autônoma" não representa uma posição que defende a emancipação social no debate cultural, mas, pelo contrario, encarna perfeitamente o tipo de violência simbólica que se exerce nas sociedades de classe para garantir a dominação cultural.
} 
colaboraram Habermas e o primeiro Honneth) serve para rejeitar o conceito de indústria cultural - com ar de preocupação pelas lutas das classes subalternas e pelo bom senso antes que este possa expor sua potencialidade teórica.

Para superar este impasse resulta imprescindível mostrar como, apesar de todas as referências que pudessem justificar aquela imagem, ela não capta o essencial da interpretação que fizeram Adorno e Horkheimer a respeito da arte, das novas tecnologias e da cultura de massas. Ao analisar esta imagem com cuidado, vê-se que ela depende basicamente de uma interpretação parcial (e interessada) da análise que eles propuseram da relação que existe entre a arte, a técnica e a política no capitalismo tardio. Conforme esta interpretação, seu pessimismo em relação aos resultados da expansão das modernas técnicas de produção econômica à esfera cultural teria conduzido-os, em termos abstratos e inconsistentes com os resultados dos estudos empíricos ${ }^{90}$, a um pessimismo drástico em relação a tudo o que os novos meios de reprodução e circulação cultural faziam possível. Qualquer pesquisador que se interesse pelos estudos culturais contemporâneos já leu

90 Habermas destaca, contra a interpretação de Adorno, a ambivalência dos meios de comunicação de massas, que vacilam entre seu "potencial autoritário" e seu "potencial emancipatório". Esta ambivalência teria sido verificada nos estudos empíricos que sublinham o caráter contraditório que provém do fato de que:

"-O centros emissores estão expostos a interesses rivais e de modo algum podem integrar sem descontinuidades os pontos de vista econômicos, politicoideológicos, profissionais e os relativos à estética dos meios;

-Os meios de comunicação de massas normalmente não se podem subtrair sem conflitos às obrigações provenientes de sua missão jornalística;

-As transmissões de modo algum respondem só ou predominantemente aos estândares da cultura de massas, e, inclusive quando adotam as formas triviais de entretenimento popular, podem muito bem conter mensagens críticas, "popular culture as popular revenge»;

-As mensagens ideológicas não acertam o alvo de seus destinatários porque o significado pretendido, sob as condições de recepção que impõe um determinado fundo subcultural, transformam-se com frequência em seu oposto;

-A lógica própria da prática comunicativa cotidiana põe-se na defensiva contra as intervenções diretamente manipuladoras dos meios de comunicação de massas, e porque

-A evolução técnica dos meios eletrônicos não discorre necessariamente na direção de uma centralização das redes, ainda quando o "video pluralism» e a "television democracy» sejam por enquanto pouco mais que visões anarquistas". Habermas (1987b): 553-554. 
alguma vez essa extensa lista de tudo o que "Adorno reprovava", que começa pelo cinema, pelo jazz e pelos Beatles, continua com o realismo literário e pictórico, a arquitetura funcional, a cultura popular, e conclui, claro, com a arte política. É digno de destacar o fato de que nessa lista do artisticamente "não-verdadeiro" que lhe é atribuída figura sempre, em primeiro lugar, o cinema. Segundo esta estendida interpretação, Adorno teria rechaçado em sua crítica cultural ao cinema enquanto tal, em termos absolutos, prévios a qualquer consideração particular dos filmes realmente existentes ou possíveis.

Quando se promove a imagem do "mandarinismo cultural" afirma-se que Adorno e Horkheimer teriam rejeitado o cinema por considerá-lo uma arte degradada, um dispositivo cultural que nasceu na indústria e é integralmente responsável pela degradação - para dizêlo brechtianamente - das "velhas e boas obras de arte". Segundo esta interpretação, o cinema teria se transformado para Adorno e Horkheimer em um paradigma dos instrumentos da alienação cultural no capitalismo tardio. A dependência desse diagnóstico a respeito do cinema da questão das novas técnicas de reprodução da arte é evidente. ${ }^{91}$ Só aquele que pensa que é a intervenção da técnica na cultura a responsável pelo seu caráter alienante e repressivo pode realizar uma crítica totalizadora frente ao cinema, a arte técnica par excellence.

Entretanto, estas interpretações críticas da visão "apocalíptica" de Adorno e Horkheimer acerca do desdobramento histórico dos novos meios técnicos e sua influência nas transformações da arte e da política deixam de lado um elemento essencial desta discussão. Apesar de que em muitos aspectos pode resultar justa a crítica a certas unilateralidades de sua interpretação da cultura de massas, não se pode desconhecer o fato de que as teses mais significativas de Adorno acerca da arte moderna destacam a importância da técnica em sua constituição interna, em sua autonomia e em sua relação com o mundo externo. ${ }^{92}$ Ao associar Adorno com essa vaga imagem do pessimismo

\footnotetext{
${ }^{91}$ Cfr., Adorno e Benjamin (1995): 161-175, 180.

92 Cfr., Adorno (ÄT) 56: "Die Spitze, welche Kunst der Gesellschaft zukehrt, ist ihrerseits ein Gesellschaftliches, Gegendruck gegen den stumpfen Druck des body social; wie der innerästhetische Fortschritt, einer der Produktivkräfte zumal der Technik, dem Fortschritt der außerästhetischen Produktivkräfte verschwistert. Zuzeiten vertreten ästhetisch entfesselte Produktivkräfte jene reale Entfesselung, die von den Produktionsverhältnissen verhindert wird. Vom Subjekt organisierte Kunstwerke vermögen, tant bien que mal, was die subjektlos organisierte Gesellschaft nicht zuläßt; die Stadtplanung
} 
cultural, que por certo chegou a converter-se em uma ideologia muito difundida nos primeiros anos do século passado na Alemanha ${ }^{93}$, termina-se obscurecendo o autêntico conteúdo de sua crítica à indústria cultural. ${ }^{94} \mathrm{O}$ engano torna-se explícito somente se recordarmos aqui esse grande pessimista cultural que foi Oswald Spengler, este sim decididamente elitista e propenso a uma ideia hierárquica de autenticidade cultural, para quem o rechaço à influência da técnica na arte servia para estruturar uma crítica mais ampla à civilização e às formas de vida das grandes cidades modernas, nas que via florescer aterrorizado "perversões como o cinema, o expressionismo, a teosofia, as lutas de boxe, as danças de negros, o pôquer e as carreiras" $" 95$. Porém, foi o próprio Adorno quem apontou claramente o caráter ideológico e o esgotamento histórico deste tipo de críticas neorromânticas da cultura:

A crítica tão apreciada pelos apologistas tradicionalistas de todos os graus: "É isso ainda música?" é estéril; o que deveria ser analisado em concreto seria o que é a desartificação da arte (Entkunstung der Kunst), isto é, uma praxe na qual a arte aproxima-se irrefletidamente, neste lado de sua dialética, com o extraestético. Frente a isto, aquela pergunta estandardizada quer obstaculizar o movimento dos momentos claramente separados entre si em que consiste a arte com ajuda de seu abstrato conceito superior. Entretanto, hoje a arte manifesta-se mais viva ali onde desintegra seu conceito superior. (ÄT: 271)

bereits hinkt notwendig hinter der eines großen zweckfreien Gebildes her. Der Antagonismus im Begriff der Technik als eines innerästhetisch Determinierten und als eines außerhalb der Kunstwerke Entwickelten ist nicht absolut zu denken. Er entsprang historisch und kann vergehen."

93 Para uma visão detalhada das controvérsias que ocorreram na Alemania em princípios do século passado, a partir do surgimento de uma cultura urbana intensa, que se diferenciava progressivamente, pela ação dos novos meios técnicos da reprodução, da cultura rural, letrada e elitista ver: Kaes, A. e Levin, D., "The Debate about Cinema: Charting a Controversy (1909-1929)", in: New German Critique, № 40 (Special Issue on Weimar Film Theory): p. 7-33, 1987.

${ }^{94}$ Adorno e Horkheimer fizeram uma distinção clara entre cultura popular, cultura de massas e indústria cultural que poucos dos seus comentaristas críticos consideram com justiça. O próprio conceito carrega nessa distinção e inscreve seu estudo no marco de um paradoxo (a cultura sendo produzida industrialmente e a indústria dedicando-se à produção de cultura), que se perde por completo quando se pretende que o alvo da crítica de Adorno e Horkheimer está encaminhado à cultura popular ou à cultura de massas.

95 Spengler, O., Der Untergang des Abendlandes: Umrisse einer Morphologie der Weltgeschichte, Munich, Beck, 2 v., 1923, p. 122. 
Para compreender a autêntica crítica de Adorno e Horkheimer ao lugar da técnica na neutralização da arte (que se faz efetiva $n a$ indústria cultural) temos que atribuir a essa passagem da Teoria Estética um valor paradigmático. Segundo esta perspectiva a causa deste processo nas sociedades modernas avançadas não se radica nos meios técnicos de reprodução em massa das obras de arte, mas na supressão da dialética entre o estético e o extraestético que o uso desses meios propicia. Para Adorno, existe uma supressão idêntica desta dialética tanto naquelas tendências que promovem uma "arte pura" (que rechaçam qualquer contato com a técnica moderna), como nas sínteses "irrefletidas" que as novas tecnologias fazem possíveis entre o mundo estético e o extraestético (interpretado este último em suas abstração e coisificação). Este é o núcleo central da discussão.

Agora bem, se para Adorno a situação da arte revela no mundo contemporâneo que esta dialética está "mais viva" ali onde "desintegra seu conceito superior", não se poderia transformar o cinema, a arte baixa e desintegradora por excelência, em um fecundo agente deste movimento, de uma vez crítico e regenerador das condições da experiência estética? Num sentido contrário a esta proposta, mais destacando também a importância do tema, na crítica de Habermas a Adorno o cinema transforma-se num exemplo limite que lhe permite desacreditar o enfoque teórico adorniano e legitimar seu próprio marco teórico para a análise cultural. ${ }^{96}$ Para Habermas, em suas análises a respeito do cinema, Adorno demonstrou que "não tem uma ideia clara do caráter radicalmente ambivalente do controle social exercido pelos meios de comunicação" (Habermas, 1987a: 473).

Ao tentar provar a falsidade do conceito de indústria cultural e da teoria da sociedade que o sustenta, Habermas retoma sua rígida distinção entre meios de controle

\footnotetext{
96 Cfr., Habermas (1987a) 473: “Adorno adota uma perspectiva de crítica da cultura, que, frente às esperanças um tanto apressadas que Benjamin depositou na força emancipatória da cultura de massas naquele momento, sobretudo do cinema, dá a seus escritos, e com razão, um tom cético. Porém, por outro lado, não tem, como veremos, uma ideia clara do caráter radicalmente ambivalente do controle social exercido por intermédio dos meios de comunicação de massas. Uma análise como a sua, que parte da forma mercadológica dos meios culturais, associa os novos meios de comunicação de massas ao dinheiro, mesmo quando as semelhanças estruturais não chegam muito longe. Porque enquanto o dinheiro sustitui o entendimento linguístico como mecanismo de coordenação da ação, os meios de comunicação de massas seguem dependendo do entendimento linguístico. Estes constituem-se em reforçadores técnicos da comunicação linguística, que superam distâncias no tempo e no espaço e multiplicam as possibilidades de comunicação; que adensam a rede de ação comunicativa, mas sem se desconectar das orientações de ação dos plexos do mundo da vida."
} 
social e meios de entendimento recíproco. No caso de Habermas, o cinema serve de exemplo para demonstrar que os meios de comunicação de massas nunca podem ser identificados - como o fez Adorno - com meios de controle social como o dinheiro, dado que "enquanto o dinheiro substitui o entendimento linguístico como mecanismo de coordenação da ação, os meios de comunicação de massas seguem dependendo do entendimento linguístico" (Ibid.). Como o cinema é, em última instância, um artefato linguístico, no contexto da ação social ele não pode ser equiparado a um mero meio técnico de coordenação da ação e controle da subjetividade. Ele pode ser tendencialmente "colonizado" pela racionalidade administrativa e pelos interesses do poder, mas possui internamente, na sua constituição linguística, um limite objetivo e uma conexão com o mundo da vida que impede que suas produções "permaneçam blindadas contra a possibilidade de ser reprovadas por atores capazes de responder autonomamente" (Habermas, 1987b: 553). Esta é a última palavra de Habermas a respeito da questão, que justifica a refutação do conceito de indústria cultural.

Porém, gostaríamos de tomar esta pequena controvérsia a respeito do cinema para abrir o debate em relação ao conceito de cultura na teoria crítica. É a alternativa habermasiana a única interpretação crítica e não-reducionista possível dos novos meios de comunicação de massas? Foi tão unilateral a reflexão de Adorno a respeito do cinema e da técnica? Não seria possível transformar o cinema em um caso emblemático de uma interpretação mais complexa do pensamento de Adorno acerca da relação da técnica com a arte e a cultura de massas? Apesar do que podem sugerir algumas passagens isoladas dos seus textos, uma releitura serena de seus escritos permite afirmar que Adorno não examinou nunca o cinema e a cultura de massas "de cima", a partir desse tipo de juízos normativos que acreditam possuir o "conceito superior" da arte. Se nós examinamos em detalhe a questão, pode-se ver que sua crítica das afinidades que existem entre o cinema e a indústria cultural não supõe nem a aversão letrada da passagem "de uma cultura da palavra a uma cultura da imagem", nem a oposição tradicionalista às novas relações entre o estético e o extraestético que as novas técnicas permitiam. Pelo contrário, pode-se encontrar em Adorno uma autêntica dialética do cinema, que remete a um duplo significado da técnica na produção e reprodução da cultura no capitalismo tardio, constituindo este o autêntico desafio que ele coloca na reflexão crítica da modernidade cultural. Analisando o conjunto 
de seus escritos a respeito do cinema vou tentar mostrar os dois momentos desta dialética, começando pela sua determinação no centro da indústria cultural (a), para logo poder explorar as potencialidades artísticas intrínsecas à técnica cinematográfica que Adorno pensou como um "devir arte do cinema" (b). Finalmente, tentarei utilizar essa análise para reformular a tese de Adorno referida à dialética da modernidade cultural (c).

a) A determinação do cinema no centro da indústria cultural

Para compreender as afinidades que Adorno e Horkheimer encontram entre o cinema e o capitalismo tardio (ou monopólico) basta não deixar cair a complexidade de uma pergunta: em que - e em quantos - sentidos o cinema é uma indústria? Responder a esta pergunta implica em começar sublinhando sua dependência - histórica e estrutural com respeito ao capital financeiro e aos recursos técnicos das grandes indústrias. Esta é uma condição necessária tanto para sua produção quanto para sua circulação massiva. $\mathrm{O}$ argumento de Benjamin a esse respeito é bem conhecido: como não acontece com nenhuma outra arte (talvez excetuando-se a arquitetura), o cinema, para a realização de cada uma de suas obras, necessita de uma enorme disponibilidade de recursos financeiros e de uma organização do trabalho coletivo tão planejado que faz lembrar, em todos seus detalhes, o próprio processo da produção industrial.

Historicamente a dependência do cinema dos grandes agentes econômicos implicou uma subsunção da "nova arte" aos interesses de setores muito concentrados da economia. E não se tratava meramente da subsunção formal da arte ao modo de produção capitalista por meio da valorização das obras no mercado, mas sim de sua subsunção real por meio de conexões sistêmicas com os setores dominantes da economia monopólica altamente planejada. ${ }^{97}$ Estes poderosos interesses já não procuravam no cinema - como puderam fazê-lo, em outras épocas, monarcas, nobres e grandes burgueses com as outras artes que

\footnotetext{
97 Cfr., Adorno e Horkheimer (DA), 144: "Die Abhängigkeit der mächtigsten Sendegesellschaft von der Elektroindustrie, oder die des Films von den Banken, charakterisiert die ganze Sphäre, deren einzelne Branchen wiederum untereinander ökonomisch verfilzt sind. Alles liegt so nahe beieinander, daß die Konzentration des Geistes ein Volumen erreicht, das es ihr erlaubt, über die Demarkationslinie der Firmentitel und technischen Sparten hinwegzurollen."
} 
adquiriam no mercado - um bem que tivesse para eles um valor de uso, um serviço que pudessem exigir que lhes fosse oferecido em termos pessoais. No caso do cinema, a relação entre o poder instituído, o mercado e a arte é completamente diferente. Quem governa a arte nesta situação não pretende obter imediatamente algo para si (o uso da obra para a satisfação de finalidades pessoais), mas interessa-se exclusivamente pelo seu potencial para a produção de valor de troca. Quando os chefes dos Trusts navais ou elétricos interessavam-se pelo financiamento de um filme não o faziam para serem imortalizados frente a seus congêneres ou para demonstrar ao mundo sua onipotência, mas para ampliar a esfera de produção de mercadorias de suas empresas. Neste caso, o poder não se infiltra na arte por meio do consumo, ou seja, do uso de suas propriedades objetivas, mas por meio da sua produção com o objetivo da valorização mercantil. Aqui radica-se a primeira especificidade que descobre Adorno: para os interesses que dominam o novo sistema econômico monopolista a obra já não é um bem que adquirem no mercado para extrair de seu valor de uso um valor cultural extraeconômico (prestígio, saber, poder etc.), mas sim transformou-se em uma matéria simbólica suscetível de ser elaborada e lançada por eles no mercado com um lucrativo valor de troca.

Por isso, não devemos confundir a crítica de Adorno à indústria cultural com o mero fato da subsunção formal da obra de arte ao mercado (situação que historicamente é muito anterior à gestação desta indústria). Tampouco trata-se da "generalização do caráter mercantil" das obras, da mera ampliação quantitativa do mercado da arte. Existe, pelo contrário, uma diferença qualitativa, que o cinema revela de modo exemplar: já não é o produto artístico o que ingressa, em maior ou menor quantidade, no mercado, mas sim são os grandes agentes econômicos do mercado os que ingressam na esfera de produção da arte. Este é o primeiro sentido que Adorno atribui ao conceito de indústria cultural e é um dos sentidos nos quais o cinema é, paradigmaticamente, uma indústria.

Do anterior se deduz outra determinação relevante. Se o cinema integra-se em termos sistêmicos à economia, como uma empresa produtora de mercadorias, demandará para seu êxito econômico de um público consumidor diferente ao do tradicional mercado da arte. Dado que não pode oferecer essa unicidade objetiva das outras artes, que poderia atrair um destinatário individual que se pretendesse singularizar precisamente a partir dela, e dado que tampouco existem os consumidores individuais que sejam capazes de garantir 
adequadamente as cifras investidas em cada filme, o cinema procura necessariamente um público massivo pós-individual, sabedor de que a ampliação do universo de seus destinatários não reduz em nada seu valor, mas é, pelo contrário, o único meio para realizálo plenamente. O fait social cinematográfico revela que "as distinções enfáticas, como aquelas que existem entre filmes dos tipos $a$ e $b$ ou entre as histórias de revistas de diferentes preços, não estão fundadas na realidade, mas servem para classificar e organizar os consumidores, para se apropriar deles sem desperdício" (DA: 144).

Historicamente esta condição fez que surgisse a necessidade de adaptar o conteúdo dos filmes às necessidades dos consumidores, com uma condição: estas necessidades só podiam ser "interpretadas" pelas empresas culturais por meio de procedimentos de investigação empírica, que faziam dessas "necessidades" algo quantificável e calculável. Tornaram-se assim imprescindíveis os estudos das necessidades dos consumidores culturais, a investigação das preferências do público no que se refere ao conteúdo e à experimentação científica da aceitação de todos os projetos que mereceriam logo ser filmados. As diferenças dos produtos cinematográficos interpelam um público no qual "cada um deve comportar-se, por assim dizer, espontaneamente, de acordo com o level determinado em forma antecipada por índices estatísticos e dirigir-se à categoria de produtos de massa que tem sido preparada para seu tipo" (DA: 144). Este novo planejamento do consumo, que se obtinha na esfera da circulação, estava orientado a evitar "a anarquia da produção". Por sua vez, para Adorno esta era a causa da terrível estandardização das obras cinematográficas, que aparecia como uma autêntica necessidade para sua existência. Um segundo sentido, então, do caráter industrial do cinema, estará dado pelo planejamento estandardizado de sua produção, baseado no conhecimento das necessidades de múltiplos consumidores e de sua capacidade para induzir a criação de uma demanda efetiva para seus produtos.

Mas o cinema não toma da grande indústria só suas estratégias para racionalizar a produção. Também toma dela a ideologia com a qual se apresenta a si mesma e justifica o conteúdo particular de cada um de seus produtos. Para Adorno ambos - o cinema e a grande indústria - dizem o mesmo a seus potenciais detratores: "tinha que ser assim para 
poder existir". A racionalidade técnica é a firme ideologia que os sustenta. ${ }^{98}$ Se alguém pretende criticar o conteúdo de um filme e aponta, como causa de sua rejeição, o processo de estandardização geral do qual são vítimas as obras cinematográficas, rapidamente se responderia que esse processo responde a uma necessidade técnica, anterior a qualquer decisão de ordem estética ou política. No cinema o proceder de uma determinada maneira e não de outra parece vir dado pelos próprios requisitos "da coisa", aqueles que fazem possível sua existência. Como um organismo que somente pode reagir repetindo os modos de comportamento que resultaram eficazes em situações semelhantes do passado, o cinema se justifica a si mesmo fazendo da técnica uma ideologia que impede a reflexão a respeito de seus procedimentos. Para ser eficaz parece ter que renunciar à dialética interna das diversas legalidades formais e neutralizar sua relação externa com a sociedade.

Todas estas determinações, que completam a subsunção real da arte ao modo de produção capitalista, encontram no caráter "industrial" do cinema um representante "típico ideal". Poderíamos resumir sua estrutura do seguinte modo:

1. A produção da obra de arte perde sua diferença em relação ao processo global de produção de bens econômicos (diferença que possuía quando desempenhava uma função no centro do culto religioso e durante o processo de sua autonomização).

2. A circulação da obra passa a depender de uma demanda estandardizada, estatisticamente determinada, que regula o horizonte dos projetos realizáveis.

\footnotetext{
98 Cfr., Adorno e Horkheimer (DA), 142: "Lichtspiele und Rundfunk brauchen sich nicht mehr als Kunst auszugeben. Die Wahrheit, daß sie nichts sind als Geschäft, verwenden sie als Ideologie, die den Schund legitimieren soll, den sie vorsätzlich herstellen. Sie nennen sich selbst Industrien, und die publizierten Einkommensziffern ihrer Generaldirektoren schlagen den Zweifel an der gesellschaftlichen Notwendigkeit der Fertigprodukte nieder. Von Interessenten wird die Kulturindustrie gern technologisch erklärt. Die Teilnahme der Millionen an ihr erzwinge Reproduktionsverfahren, die es wiederum unabwendbar machten, daß an zahllosen Stellen gleiche Bedürfnisse mit Standardgütern beliefert werden. Der technische Gegensatz weniger Herstellungszentren zur zerstreuten Rezeption bedinge Organisation und Planung durch die Verfügenden. Die Standards seien ursprünglich aus den Bedürfnissen der Konsumenten hervorgegangen: daher würden sie so widerstandslos akzeptiert. In der Tat ist es der Zirkel von Manipulation und rückwirkendem Bedürfnis, in dem die Einheit des Systems immer dichter zusammenschießt."
} 
3. A recepção, como experiência estética, vê-se obstaculizada pela racionalidade técnica que penetra nas obras, que só admite juízos referidos à eficácia dos procedimentos e ao desempenho dos participantes.

Esta subsunção é o contrário, evidentemente, do processo de autonomização da arte. É ela que torna impossível a autonomia (relativa) do artista, de seus meios e técnicas produtivas; é ela a que destrói o caráter singular da esfera do consumo de arte; e é ela a que dissolve a diferença da experiência estética em relação aos outros juízos socialmente válidos. Esta tripla neutralização explica, pelo menos nos termos de uma sociologia da arte, por que a crítica do fait social "cinematográfico" representa um momento paradigmático do conceito de indústria cultural. Ela também revela em que medida, para Adorno, a autonomia da arte na modernidade cultural só pode ser determinada numa relação de tensão e oposição com respeito à indústria cultural. Neste caso, a crítica da técnica na arte é colocada por Adorno e Horkheimer exclusivamente a serviço da crítica da ideologia da arte como técnica. O que quer dizer que eles não fazem uma "crítica totalizadora" da incorporação da técnica na cultura, mas fazem uma crítica radical da sua função nas sociedades da modernidade tardia. ${ }^{99}$

No caso do cinema, a questão da técnica fica frequentemente reduzida - em termos que revelam a operação ideológica que Adorno e Horkheimer procuram criticar - à consideração do conjunto de procedimentos que fazem possíveis a reprodução e a exibição mecânica de imagens em movimento. Sem perceber sua importância, assistimos assim a uma simplificação interessada, que reduz a difícil questão da técnica no cinema à ideologia do cinema como pura técnica, socialmente neutra e de alcance universal. A partir desta ideologia se procura fixar uma falsa identidade entre a técnica cinematográfica, os novos meios de reprodução de bens culturais (nos que o cinema se transforma em sua relação com a sociedade) e as técnicas de produção em série da grande indústria (que o cinema incorpora internamente). E é esta ideologia, que se estende para o conjunto da arte, pretendendo determinar o começo de uma nova era na qual a tecnologia e a cultura ter-seiam fundido em uma unidade perfeita, a que criticaram Adorno e Horkheimer em seu

\footnotetext{
${ }^{99}$ Cfr., Adorno e Horkheimer (DA): 142 e ss.
} 
momento. Como se pode ver, esta crítica não depende de nenhum prejuízo contra a técnica, nem do uso de um conceito "superior" do que deveria ser a arte.

Ao repassar as teses da Dialética do Esclarecimento teremos que reconhecer a denúncia de um triplo caráter ideológico no fait social cinematográfico, que serve para esclarecer algumas das determinações mais importantes daquilo que Adorno e Horkheimer denominaram indústria cultural. Por um lado, a própria ideia de reprodução opera teórica e praticamente em termos enganosos. Situar o cinema como um aparelho que só reproduz, através de procedimentos técnicos, imagens e discursos considerados independentes do mecanismo que opera a reprodução, implica ressaltar unilateralmente sua capacidade (real) de copiar fielmente a realidade, de duplicar-se sem a dependência de um original ("aurático") e de exibir-se sem limites espaço-temporais, ocultando as outras enormes operações produtivas (semióticas, psicológicas, morais etc.) que não deixa de realizar permanente e minuciosamente. Diferentemente dos "historiadores da arte e dos advogados da cultura" que apresentam o cinema como uma máquina de destruição das energias estilísticas da arte ocidental, Adorno e Horkheimer relacionam-no com o paroxismo das mesmas, com uma capacidade obsessiva de intervir e modificar os materiais que o aparelho reproduz:

A tradução estereotipada de tudo, mesmo daquilo que ainda não foi pensado, dentro do esquema da reprodutibilidade técnica, supera em rigor e validez todo verdadeiro estilo. [...] Nenhum construtor de igrejas medievais teria inspecionado os temas dos vitrais e das esculturas com a desconfiança com a qual a direção do estudo cinematográfico examina um tema de Balzac ou de Victor Hugo antes que este obtenha o imprimatur que permitirá que possa continuar. (DA: 148-149)

Porém, esta produção obsessiva dos artefatos culturais desaparece quando o "aparelho" consegue aparecer como um mero mecanismo de reprodução de algo que o precede e sobre o qual não teria nenhuma intervenção. A neutralidade que projeta a imagem do aparelho cinematográfico transforma-se em uma poderosa ideologia, precisamente porque pode esconder o modo de produção de suas obras "simbolicamente constituídas" (assim como esconde as determinações socioeconômicas e as relações de poder que se inscreveram no mesmo processo de produção). Deste modo, o conjunto das operações do cinema (e da indústria cultural) inscreve-se socialmente não no nível do discurso, na forma 
de um discurso particular que reclama frente aos espectadores uma determinada pretensão de validez artística ou de verdade, mas situa-se no plano da própria linguagem, com a qual o público vai ter que se expressar em relação a esses bens culturais. Pela aparente neutralidade do dispositivo de reprodução, o jargão, as proibições e os controles do cinema não são percebidos como os elementos de um discurso que circula entre outros discursos, mas começam a ser utilizados "com tanta facilidade, liberdade e alegria, como se fossem a própria língua que tem desde sempre vencido o silêncio" (DA: 149). Na reprodução cinematográfica o estilo termina por transformar-se ideologicamente no seu outro, na representação imediata da natureza, que aparece agora como um meio imparcial, facilitador da comunicação universal.

Quanto maior é a redução da distância entre a imagem e a vida cotidiana, maior é a eficácia desta operação dos monopólios culturais, que podem fazer circular seus artefatos simbólicos como se fossem a realidade nua, a linguagem que surge da "vida mesma", sem artifícios, ou pretensões discursivas particulares. A falsa transparência que consegue evocar o aparelho de reprodução cinematográfico dissimula, deste modo, suas infinitas operações simbólicas ao inscrevê-las diretamente no plano da faticidade, transformando suas seleções e articulações em elementos puros e articulações espontâneas da própria realidade, que o aparelho limita-se a duplicar. ${ }^{100}$ Seu resultado é um discurso completamente naturalizado, fossilizado, e uma natureza que é obrigada a falar a partir de seu mutismo. No discurso cinematográfico temos claramente o exemplo de um discurso que não pretende ser reconhecido como verdadeiro, justo ou belo, mas como um não-discurso que, porém, consegue operar eficazmente como um puro meio de comunicação. Este meio de comunicação "demonstra a divindade do real tão só através da repetição cínica do real”, dado que sua capacidade de provar ao público a existência de alguma coisa não pretende seguir um critério normativo estrito, mas oferecer uma "evidência fotológica opressiva" (überwältigend photologische Beweis, DA: 170).

Um segundo registro no qual a reprodutibilidade técnica do cinema opera ideologicamente dá-se no plano do conteúdo ou, mais precisamente, na capacidade da

\footnotetext{
${ }^{100}$ Para uma análise desta "ideologia cinematográfica" da transparência na imagem e da neutralidade no discurso, ver: Xavier, I., O discurso cinematográfico. A opacidade e a transparência, ed. Paz e Terra, São Paulo, 2005.
} 
técnica de reprodução de gestar um conteúdo ideológico. Adorno e Horkheimer destacam reiteradamente no ensaio a respeito da indústria cultural a afinidade que existe entre a reprodutibilidade técnica de qualquer conteúdo simbólico e a publicidade (Reklame). Tal afinidade não é uma pura semelhança externa, mas um requisito que opera internamente, e que funde na publicidade a tendência socio-cultural à repetição do mesmo com a economia capitalista.

A repetição que o mecanismo de reprodução facilita, organiza objetivamente a transformação das imagens e os discursos numa variada série de clichês, figuras retóricas estandardizadas e produtos culturais nivelados pela monotonia dos seus temas e suas pretensões formais. Tais estandardização e nivelação constituem a base do discurso publicitário, que transforma as palavras e as imagens em meros meios do tráfico de informações e da promoção do consumo. Para Adorno e Horkheimer, a técnica de reprodução mecânica dos artefatos culturais própria do cinema já contém, intrinsecamente, a afinidade com o dispositivo publicitário que logo vai ser realizada e desenvolvida historicamente a partir de outros aparelhos tecnológicos de reprodução (rádio, TV etc.). "Técnica e economicamente publicidade e indústria cultural fundem-se em uma unidade. Tanto numa como na outra a mesma coisa aparece em inumeráveis lugares e a repetição mecânica do mesmo produto cultural é já a do mesmo slogan da propaganda (DA: 187)." Com este processo Adorno e Horkheimer não pretendem simplesmente assinalar a utilidade que a publicidade teria achado na reprodutibilidade técnica cinematográfica, mas a profunda transformação no sentido das exigências do discurso publicitário que a repetição técnica provocou na esfera cultural em geral. O momento ideológico da técnica cinematográfica deve ser achado neste caso na sua capacidade para fazer que "a publicidade transforme-se na arte por excelência" (DA: 186), que domina secretamente as diversas esferas (pseudo)autônomas nas quais se diferencia a cultura moderna.

Mas Adorno e Horkheimer também examinaram o caráter ideológico da relação que se dá no cinema entre técnica, arte e cultura de massas em outro sentido. Neste último caso, trata-se essencialmente daquilo que a transformação do cinema em mero aparelho de reprodução técnico-cultural inibe e reprime de sua própria constituição objetiva. A racionalidade técnica no cinema transforma-se em ideologia, neste caso, porque impede o 
desenvolvimento das técnicas de produção artísticas especificamente cinematográficas. ${ }^{101}$ Do que se trata agora não é da falsa aparência de neutralidade e transparência que projeta, nem de sua afinidade com o dispositivo publicitário, mas sim das forças técnicas de produção que inibe, no centro dessa falsa aparência. Aqui começa o que - seguindo estritamente Adorno e Horkheimer - devemos chamar a dialética do cinema.

b) $\mathrm{O}$ devir arte do cinema.

Poderia o cinema desencadear um processo diferente ao de sua completa determinação pela indústria cultural? Seria o cinema capaz de realizar uma mediação entre o estético e o extraestético que não tendesse automaticamente para a "síntese irrefletida" de seus momentos? Poderia o cinema devir arte? Ou, ainda mais, poderia o cinema ilustrar o processo geral do devir arte? Adorno fez estas perguntas explicitamente no final do ano 1966, quando publica um curioso artigo intitulado: "Filmtransparente"102. O problema central que lhe interessa indagar agora é o da linguagem cinematográfica e os meios técnicos que fariam possível sua singularidade. ${ }^{103}$

O texto é breve, mas está cheio de indicações, de indícios que permitem esboçar uma estética do cinema. A pergunta de Adorno é pela capacidade das obras cinematográficas de reverter os efeitos sistemáticos da empresa técnico-cultural, recusando assim internamente a consumação fetichista do seu significado. Tratar-se-ia de algo assim como o "despertar do cinema" como meio expressivo artístico, no centro de um mecanismo inóspito. No entanto, neste texto, os conceitos que vão permitir a compreensão do processo

\footnotetext{
101 Para uma discussão mais aprofundada desta tese, ver: Metz, Ch., Langage et cinéma, Paris, Larousse, 1971.

${ }^{102}$ Cfr., Adorno (KG I): 353-361.

103 Um dos textos mais originais que se publicaram sobre esta outra direção dos estudos sobre cinema de Adorno é o de Gertrud Koch, "Mimesis und Bilderverbot in Adornos Ästhetik. Ästhetische Dauer als Revolte gegen den Tod", in: Babylon, ( $\left.N^{\circ} 6\right)$ : pp. 36-45, 1989. Seu tema principal é a afinidade que descobre Adorno entre a linguagem cinematográfica e a escrita. Para uma análise referida à oposição que existe entre os procedimentos da indústria cultural e aqueles da arte autônoma no cinema, ver: Hansen, M, "Mass culture as Hieroglyphic Writing: Adorno, Derrida, Kracauer", in: New German Critique, (N 56): p. 43-73, 1992.
} 
do devir arte do cinema não implicam nenhum procedimento de abstração ou separação com relação às determinações técnicas fundamentais desse meio, dado que este processo depende da possibilidade de subvertê-las internamente. Esta é uma questão-chave na crítica cultural de Adorno. A habermasiana possibilidade de "dizer não" ao discurso dos grandes meios de comunicação de massas já não é concentrada na instância normativa exterior (e quase ontológica) da esfera pública, na qual se reproduzem os "atores capazes de responder autonomamente". Tampouco a racionalidade administrativa das grandes empresas culturais é fixada dogmática e ingenuamente fora dos "âmbitos de ação constituídos como mundo da vida". A resistência aos efeitos niveladores e falsificadores no conteúdo das obras deve ser analisada - no tipo de crítica cultural que Adorno tenta fundamentar - no objeto, na contradição interna dos elementos que constituem o artefato cultural tecnicamente produzido. Neste caso, a questão da técnica adquire um sentido mais complexo e sua análise transforma-se em um aliado indispensável.

Nas sucessivas referências nas quais Adorno pronuncia-se em Filmtransparente a favor de uma linguagem artística especificamente cinematográfica, ele utiliza uma série de comparações enigmáticas desta "linguagem técnica" com a escrita, e de ambos com o universo do sonho, a lanterna mágica dos jogos infantis e a experiência da beleza natural. Repassemos a primeira referência de Adorno in extenso:

A estética do filme deveria procurar assemelhar-se a uma forma da experiência subjetiva, que possibilite a constituição da sua forma artística, contra sua origem tecnológica. A quem, depois de um ano na cidade, retira-se extensas semanas na montanha e se exercita no ascetismo em relação a qualquer trabalho, pode-lhe acontecer inesperadamente que, no sonho ou na fantasia (im Schlaf oder Halbschlaf), apareçam-lhe múltiplas imagens da paisagem vindo em direção a ele ou através dele. Estas imagens, entretanto, não se identificam entre si em uma contínua passagem de umas nas outras (gehen aber nicht kontinuierlich ineinander über), mas sim são montadas em seu próprio fluxo umas contra as outras (in ihrem Verlauf gegeneinander abgesetzt), como acontece na lanterna mágica da infância. Esta suspensão do movimento convergente das imagens do monólogo interior é a causa de sua semelhança com a escrita: não é outra coisa o automovimento que fixa, ante nossos olhos, o traço individual de seus signos. Tal movimento de imagens pode representar para o cinema o que o mundo visível é para a pintura ou o mundo acústico para a música. $\mathrm{O}$ cinema poderia devir arte como restituição objetivadora (objektivierende Wiederherstellung) deste modo da experiência. O meio técnico por excelência, ligado intimamente à experiência da beleza natural. (KG I: 355, grifos meus) 
Adorno consegue associar agora, pela primeira vez, a técnica com a experiência estética, em uma relação de negação interna dos seus efeitos niveladores na cultura. Nesta associação o cinema aparece como o meio simbólico central, como a instância na qual as técnicas modernas de produção são utilizadas (e transformadas) de tal modo que podem “devir arte”. Com esta perspectiva, a técnica já não é concebida como a grande responsável pela "degradação cultural" e pela perda da autonomia da arte. Pelo contrário, ela aparece agora ligada à genuína experiência estética. Para compreender esta passagem em sua significação teórica é importante começar pela descrição (implícita) que propõe Adorno da experiência do belo, dado que é ela a que vai operar negativamente em relação à estandardização da cultura.

O universo de metáforas e comparações que utiliza Adorno sugere uma orientação bastante clara. O belo é possível ali onde se produz uma "descontinuidade" e uma "oposição" no fluxo da representação do monólogo interior. Surge aqui imediatamente uma pergunta: que beleza é essa que exige ser pensada como descontinuidade e oposição na experiência subjetiva? Evidentemente, trata-se da peculiar conceição do belo da Teoria Estética, que rejeita a definição tradicional ou formalista e promove uma concepção dialética. ${ }^{104}$ No centro desta dialética, o outro do belo, o feio, o dissonante, aquele que desagrada ao sujeito, não aparece como algo superado pela constituição harmônica do belo, mas, pelo contrário, realiza-se como aquele que transgride e fratura a lei formal que faz dele algo belo. É este conceito "impuro", "não harmonicista" de beleza, aquele que reaparece na passagem a respeito da técnica cinematográfica, quando se equipara a experiência subjetiva da beleza natural, com a experiência de uma "descontinuidade" e de uma "oposição" na representação subjetiva. Adorno rejeita, neste aspecto, a tese kantiana que determina geneticamente a experiência do belo a partir da livre concordância entre as faculdades (imaginação e entendimento), e associa polemicamente o belo ao conflito na representação subjetiva provocada por imagens não-convergentes, não-redutíveis a uma identidade, que expressam livremente o dissonante. Quando um dispositivo técnico como a montagem consegue produzir o choque e a oposição recíproca entre as imagens, o efeito desta operação pode servir para manifestar visualmente a dialética do belo e, a partir dela,

\footnotetext{
${ }^{104}$ Cfr., Adorno (ÄT): 74 e ss.
} 
constituir uma autêntica experiência estética. Assim acontece a quem se deixa levar pelas imagens da lanterna mágica - como o pequeno protagonista da Recherche du temps perdue a quem, "logo depois de se afastar do mundo do trabalho", entrega-se à livre contemplação de uma paisagem através de uma série de imagens que "vêm em direção a ele" sem identificar-se em uma "contínua passagem de umas nas outras".

Nesta enigmática passagem Adorno afirma que existem três "aparelhos" que são capazes de produzir este tipo de imagens não-convergentes: o aparelho psíquico (no sonho), o aparelho linguístico (na escrita) e o aparelho cinematográfico (que começa já com a lanterna mágica). Em todos os casos - e por isso Adorno ressalta sua afinidade - trata-se de uma produção de imagens não-intencionais, que não dependem nem estão organizadas pelo sujeito, mas acontecem "através dele" a partir da potência do próprio aparelho. Tanto o aparelho psíquico, como o linguístico (na escrita) são capazes de reunir este tipo de elementos incompatíveis, que não podem ser sintetizados nem por sua origem, nem por sua forma, nem por seu sentido. Por sua vez, estas descontinuidades na representação podem devir uma experiência artística mediante o recurso da técnica cinematográfica. É por isso que Adorno sugere que as fraturas e os conflitos que se produzem na continuidade psíquica e linguística do sujeito monológico teriam que se transformar na autêntica "matéria-prima" do devir arte do cinema. O mecanismo específico que produz sua expressão efetiva é como temos antecipado - a técnica da montagem (que também procede da produção "industrial"), quando ela consegue transgredir a transparência da imagem fotográfica e suspende as estratégias de apropriação do percebido que pretendem resolvê-lo fazendo uso de recursos ordinários de identificação e compreensão:

Todo sentido que a câmera-olho confere ao filme, incluído o sentido crítico, infringe a lei da câmera e com isto transgride o tabu de Benjamin [que estabelece que o cinema só adquire sentido ao momento da recepção, a partir de seu "valor de exibição"]. O cinema enfrenta o dilema de encontrar um procedimento que não caia nem na arte industrial, nem no puramente documentário. A primeira resposta que se pode dar é hoje igual há quarenta anos, a montagem, a qual não intervém (eingreifen) nas coisas, mas desloca-as (rücken) numa constelação parecida com a escrita. (KG I: 357-358)

Podemos ver agora de que modo, quando o cinema procura seu procedimento artístico particular, torna-se imperioso distinguir os dois sentidos que a técnica tem no meio 
cinematográfico (distinção que Adorno reclamou a Benjamin em várias ocasiões no marco de sua discussão a respeito da nova era da arte de massas). ${ }^{105}$ No caso de não produzir esta distinção interna, a consideração das propriedades "artísticas" da técnica cinematográfica cai facilmente na armadilha da indústria cultural e aceita sua legitimação da síntese "irrefletida" entre o estético e o extraestético que promove a forma do discurso publicitário. Pelo contrário, a crítica cultural de Adorno distingue, por um lado, a técnica como procedimento imanente que produz a estrutura objetiva do filme, isso é, a montagem. Por outro lado, concebe a técnica como mecanismo que permite reproduzir ou executar o fait social cinematográfico, ou seja, o dispositivo de reprodução de imagens em movimento. Em algumas oportunidades Adorno deu a esta diferença o estatuto de uma distinção de conceito; reservou o termo "técnica" (Technik) exclusivamente para o primeiro sentido e designou as técnicas de reprodução como "tecnologias" (Technologie) culturais. ${ }^{106}$

Para Adorno, definir a técnica cinematográfica unilateralmente como mecanismo de reprodução, que permite ampliar o circuito de exibição dos bens culturais, implica inibir completamente a possibilidade de pensar uma produção técnico-cinematográfica de sentido, transformando o cinema em um mero instrumento orientado à reprodução do sentido disponível (procedimento típico da "indústria cultural" e do "meramente documental"). Ao colocar a questão da técnica cinematográfica fora do "dilema" estético, permite-se que esta seja concebida exclusivamente como um meio tecnológico que possibilita a ampliação dos circuitos de comunicação, deixando para a instância posterior e externa da recepção a determinação de seu "valor" estético. Com essa determinação a oposição entre os dois sentidos da técnica desaparece por completo. O que esta definição aceita é que a técnica cinematográfica deve ser achada exclusivamente na capacidade do mecanismo para reproduzir uma mensagem visual e sonora para um público potencialmente

\footnotetext{
${ }^{105}$ Ver Adorno e Benjamin (1995): 161-175, 180.

106 O que devemos ressaltar é o fato de que esta diferença nos usos do termo "técnica" transforma radicalmente a questão do sentido na arte e nos objetos culturais em geral. A partir desta diferença Adorno opõe a significação imanente da obra de arte, que o próprio Benjamin tinha defendido enfaticamente em seu trabalho acerca do Trauerspiel, com a significação extrínseca que propõem as obras de arte reproduzidas "tecnologicamente".
} 
ilimitado. ${ }^{107}$ No outro extremo, intensificando a dialética do cinema, aparece a primazia das técnicas imanentes. Estas se caracterizam segundo Adorno por "infringir a lei" do sentido (a transparência da câmêra), dado que revelam sem restrições a tensão, intrínseca ao médio expressivo cinematográfico, entre o princípio construtivo do dispositivo fotográfico e o princípio deconstrutivo da montagem. A particularidade da arte cinematográfica consistiria - para Adorno - na capacidade para situar esse conflito, procurando quebrar a "evidência fotológica opressiva", que tende a "divinizar" o existente por meio da sua repetição, e interromper a colonização do discurso por parte do dispositivo da publicidade, que transforma as palavras e as imagens em meios do tráfico de informações. A técnica da montagem poderia operar em ambas direções, provocando uma diferença no meio da repetição. Por esse caminho o cinema, a arte técnica par excellence, poderia "enfrentar sua origem tecnológica”. Neste sentido, a tarefa principal do cinema-arte consistiria em cuidar do lugar das imagens não-convergentes, dos discursos que não reproduzem a falsa identidade entre a imagem e a vida, e que são capazes de desencadear uma autêntica experiência da negatividade estética.

Como resulta evidente, no meio desta problematizacão da cultura por parte de Adorno aparece sua crítica à teoria da arte de massas de Benjamin. Esta crítica é mais precisa do que se costuma pensar e se apoia, em boa parte, em elementos essenciais da própria teoria da arte benjaminiana. Quando Benjamin ressalta em Das Kunstwerk im Zeitalter seiner technischen Reproduzierbarkeit o caráter negativo que a técnica cinematográfica tem no centro da história da arte ocidental, confunde - segundo a interpretação de Adorno - a negatividade da sua técnica imanente, a montagem, com a negatividade da tecnologia de reprodução de imagens, que anula a distinção tradicional entre cópia e original. Por isso, a superação do "valor cultual" (Kultwert) da arte clássica

107 Oculta-se deste modo que, para que isso seja possível, o dispositivo tecnológico tem que alinhar, sintetizar e recodificar os materiais heterogêneos com os quais trabalha, construindo-se a partir desse "esquecimento" a fantasia, típica do cinema, de uma linguagem universal transparente e um "meio de comunicação" purificado pela técnica. O cinema como tecnologia de comunicação transforma-se em um gigantesco mecanismo de unificação de imagens, sons e signos (unificação que pode ir da sincronização realista ao pastiche publicitário), que se adapta aos requisitos de percepção e compreensão do consumidor cultural. Esta posição defende enfaticamente a primazia da tecnologia sobre a técnica (que se funde com a primeira em termos ideológicos), e estabelece que a instância decisiva para a análise sociocultural é a recepção. 
depende unilateralmente na teoria de Benjamin de uma revalorização do "valor de exibição" (Ausstellungswert), organizado completamente a partir da reprodutibilidade técnica das obras. Mas com essa forma de destacar o poder crítico da técnica no âmbito da cultura, que é sem dúvidas o grande mérito do texto benjaminiano, não se diferencia entre a destituição do valor de culto da arte tradicional, que pode produzir a negatividade do cinema, da subsunção das diversas esferas culturais à lógica da indústria cultural, que gera a mesma técnica de reprodução. O que Adorno procura na sua análise da potencialidade crítica da técnica no cinema é precisamente examinar a possibilidade de constatar essa diferença na objetividade dos artefatos culturais. A distinção teórica entre a técnica imanente da montagem e a tecnologia da reprodutibilidade dirige-se nessa direção.

Contudo, a relação desta crítica do cinema de Adorno com a obra de Benjamin não é unilateral. Na passagem que citamos acima Adorno compara a montagem com a escrita e a apresentação em constelação. Exatamente Adorno diz: "a montagem, que não intervém (eingreifen) nas coisas, desloca-as (rücken) em uma constelação parecida com a escrita". A constelação é, como se sabe, uma figura da teoria do conhecimento benjaminiana. Pôr em constelação o sentido significa, tal como o assinala Benjamin no Trauerspiel, produzir uma sintese sui generis, na qual não se reforçam os traços comuns entre as representações, mas, pelo contrário, intensificam-se as tendências em direção aos extremos, na procura de um grau máximo das diferenças que se podem achar naquilo que foi "reunido". 108 A constelação benjaminiana é, então, uma estranha totalidade - no duplo sentido de que é uma totalidade anômala e uma totalidade que produz estranhamento, surpresa - que pretende manifestar a singularidade daquilo que reúne. Por oposição ao conceito, que reduz os valores diferenciais das coisas na imagem de um termo médio suscetível de compreendêlas todas, a constelação como procedimento implica a síntese de coisas irreduzíveis a uma identidade e, ao mesmo tempo, a manifestação das relações de semelhança e oposição entre elas. O que Adorno defende com a comparação entre a montagem, a constelação e a escrita é a possibilidade de que a técnica cinematográfica seja capaz de interferir na trama de nossos atos de compreensão ordinários, levando-a em direção aos extremos, registrando a multiplicidade de singularidades que permanecem invisíveis nesses atos de compreensão. Ao combinar-se com este procedimento que consiste em "levar aos extremos" um

\footnotetext{
${ }^{108}$ Benjamin, W., Ursprung des deutschen Trauerspiels, Frankfurt am Main, Suhrkamp, 1978, p. 9-39.
} 
determinado campo simbólico, a montagem poderia servir para fundamentar, benjaminianamente, o devir arte do cinema.

Alexander Kluge comentou recentemente que é o que Adorno esperava desta operação:

Ele interessava-se pela contraposição que observava entre a montagem de Eisenstein, que para Adorno tinha uma natureza retórica, e a de Godard, no qual a montagem provinha da coisa (im Gegensatz dazu Godards Montage aus der Sache kommt), da incompatibilidade (Unvereinbarkeit) entre dois planos. Neste segundo caso, gesta-se uma "terceira imagem" entre as duas imagens que a montagem reúne, a qual fica frequentemente invisível no próprio movimento do filme, sendo função da arte sustentá-la. Isto é algo tipicamente adorniano, a ideia de que em realidade não há nenhuma imagem que exista como algo dado, e que só as imagens invisíveis contam. ${ }^{109}$

Segundo este comentário, o propriamente artístico no cinema começa para Adorno quando um filme consegue apoiar estas “imagens invisíveis”. A questão da técnica no cinema deveria concentrar-se nesta pergunta: como fazer para que a montagem não naturalize o sentido das imagens e permita a aparição das imagens invisíveis? Ou seja, a pergunta não é: como se produz o milagre que faz que duas imagens diferentes possam produzir uma única significação orgânica?, mas, como faz a montagem para redimir dessa estruturação orgânica à "terceira imagem", essa que não faz parte da narração planejada pelo aparelho tecnológico? Para responder a esta questão a figura de Godard resulta particularmente adequada. Temos que lembrar que a demanda que Adorno coloca na questão da montagem, a técnica imanente do cinema, consistia em evitar uma dupla neutralização do sentido cinematográfico: por um lado, a que produz a síntese minuciosa dos diferentes registros simbólicos (imagem, som, língua) que opera no sentido da reprodutibilidade e da comunicabilidade; e, por outro lado, a neutralização que supõe a transparência do princípio fotográfico. Esses são, respectivamente, o procedimento típico da "arte industrial" e aquele do "puramente documentário". No primeiro caso, a utilização obsessiva da montagem tem uma finalidade "retórica", ou narrativa, que só serve para reproduzir um sentido anterior, extracinematográfico. No segundo caso, a ausência completa da montagem produz um efeito puramente descritivo, que não consegue

109 Kluge, A., “Nur das unsichtbare Bild zählt”, in: Berliner Tagesspiegel, 11 Sept., 2003, p. 25. 
conformar um sentido especificamente cinematográfico. $\mathrm{O}$ devir arte do cinema deveria evitar, para Adorno, estes procedimentos e procurar uma montagem que "proviesse da coisa". Agora bem, qual é essa coisa e qual é sua ligação com o que Adorno denomina imagens invisíveis? Como consegue evitar o procedimento da arte industrial e do puramente documentário? Qual é a relação entre essa montagem e a constelação, entendida como procedimento simbólico, de Benjamin? Poder-se-ia resumir nestas perguntas toda a estética do cinema de Adorno, assim como a dialética dos novos meios de reprodução técnica da cultura que ele pretende reconstruir. Para finalizar este apartado tentaremos oferecer uma resposta a esta série de questões. Nossa resposta parte da distinção sugerida por Adorno entre o ato de intervir (eingreifen) no sentido das coisas e o ato de deslocá-lo (rücken) mediante sua disposição em uma constelação simbólica.

Na concepção estética da montagem de Adorno persiste um elemento paradoxal que deve ser ressaltado. Segundo as teses centrais que temos analisado anteriormente, a montagem só pode ser utilizada artisticamente se consegue interferir e operar negativamente na linguagem fossilizada e naturalizada (pela indústria cultural). Esse é o pano de fundo: a capacidade da montagem de subverter a função ideológica da falsa aparência de neutralidade da tecnologia cinematográfica, que faz passar as operações simbólicas dos monopólios culturais como se fossem determinações das próprias coisas. Temos denominado essa operação como fossilização ou naturalização da linguagem. Contudo, caberia perguntar-se se não resulta contraditório afirmar que o procedimento que consegue desestruturar a eficácia da "falsa objetividade" do discurso da indústria cultural pode ser achado numa montagem que - se diz - "provém da coisa". Não se repete com essa apelação a operação típica da indústria cultural, que pretende demonstrar que ela não seleciona nem articula os materiais exibidos, mas que estes já possuem objetivamente a estruturação que ela se limita a reproduzir? Não teria que ser a intervenção do sujeito artístico, no comando da montagem, a encarregada de abrir "poeticamente" a linguagem fossilizada? Não deveríamos apressar-nos na tentativa de resolver este paradoxo. Porém, deve-se sublinhar que, para Adorno, no caso da objetividade da tecnologia cinematográfica e naquele da montagem que "provém da coisa", trata-se de dois objetos ou de duas instâncias da coisa radicalmente diferenciadas. De um lado, temos que colocar o objeto intencional ou o objeto pragmaticamente constituído na comunicação entre um emissor e 
um receptor (entre o produtor cinematográfico e seu público). Neste primeiro caso trata-se da "objetividade socialmente válida", na qual contribui o produtor das obras cinematográficas com suas intervenções sobre o material fílmico orientadas a criar unidades simbólicas que o público logo poderá interpretar, avaliar, responder etc. Consegue-se esta objetividade com uma seleção e uma articulação das imagens que provêm necessariamente do sujeito (o monopólio cultural) e orientam-se para outro sujeito (o público). Por outro lado, temos a coisa na qual se interessa Adorno ao pensar o uso artístico da montagem. Neste caso, o objeto define-se negativamente como um objeto nãointencional, que não faz parte da articulação sintagmática da narração cinematográfica. De fato, segundo Adorno, este outro objeto não surge da síntese significativa entre dois planos consecutivos, mas da incompatibilidade (Unvereinbarkeit) entre eles. Não se trata agora, evidentemente, da "objetividade socialmente válida" que se constrói na comunicação entre um emissor e um receptor, mas da objetividade materialmente polêmica de uma coisa que se manifesta no discurso cinematográfico separando as partes de suas unidades simbólicas.

Para compreender as teses de Adorno a respeito do cinema temos, pois, que diferenciar estes dois objetos: o objeto da comunicação, do entendimento entre o emissor e o receptor, e o objeto da discrepância entre o material (fílmico) e a função simbólica, o objeto da não-comunicação. $O$ primeiro surge da intervenção significativa por parte do produtor, a qual é, por sua vez, ocultada na falsa transparência do mecanismo cinematográfico. Esta disposição ideológica do cinema tem ficado clara na nossa reconstrução. No entanto, como deve ser pensada a produção do outro objeto, aquele que, segundo Adorno, desestrutura internamente a linguagem (cinematográfica) fossilizada? Aqui aparece uma dupla determinação: a ideia de uma "montagem que provém da coisa"; e a oposição ao procedimento do "puramente documentário". No centro da tensão que existe entre estas determinações, Adorno esclarece a operação estética da montagem a partir do procedimento benjaminiano que consiste em pôr em constelação o sentido. Para desestruturar a eficácia da "falsa objetividade" da indústria cultural, que permeia a totalidade do meio cinematográfico, não se trataria, então, de registrar com uma maior objetividade a realidade, mas de deslocar a visão para os extremos do campo da representação do filme. Em termos da montagem cinematográfica a constelação benjaminiana poderia ser traduzida como o esforço por reunir: a) enquadramentos não- 
convencionais, que façam um percurso pelos extremos do plano; b) planos contrastantes, que revelem as oposições contidas na pretensão de unidade temática de cada uma das sequências; c) ritmos diferenciados, que desestruturem o continuum temporal da ação; etc. Tratar-se-ia, definitivamente, de utilizar a montagem como instrumento de uma "totalidade saturada de tensões".

O que Adorno pretende destacar, com sua enigmática tese a respeito da "montagem que provém da coisa", é que com a articulação dos extremos da representação cinematográfica consegue-se a primazia do objeto na montagem (temos que lembrar aqui o vínculo desta análise com a tese referida à Vorrang des Objekt da Teoria Estética), por meio da contradição entre as operações de simbolização que intervém no processo. Quando a montagem desloca o espectador de aquilo que "deve ser visto" segundo os requisitos narrativos, as intervenções simbólicas aparecem, perdem sua "naturalidade" e se manifestam, fazendo que seu domínio sobre o objeto torne-se visível. Mesmo pela dificuldade, pela aspereza que essa montagem coloca no processo de compreensão do espectador, tornam-se experimentáveis por parte do público as intervenções que trabalham no processo de produção do sentido. Junto com a essas operações, agora visíveis, aparece fugazmente o objeto, que enfrenta o domínio da simbolização que padece. Uma angulação radical, um enquadramento que se desloca do centro argumentativo da cena, quando são bem realizadas, conseguem produzir uma distância entre o objeto filmado e o procedimento de seleção e articulação com o qual cobra sentido. Esses deslocamentos da montagem (rücken), que não são intervenções (eingreifen) nem decisões sobre o sentido das coisas, são os que permitem falar de uma "montagem que provém da coisa". O objeto que aparece neste uso da montagem é precisamente aquele que Adorno denomina o "objeto invisível", que a arte cinematográfica deveria ser capaz de produzir e preservar contra os efeitos "naturais" da sua linguagem tecnológica.

Por último, devemos sublinhar o fato de que esta interrupção momentânea do fluxo comunicativo com o público, que o "objeto invisível" provoca, não implica nenhuma condenação ao mutismo da obra de arte. Pelo contrário, essa não-comunicação da montagem que desloca o sentido numa constelação tem para Adorno um enorme valor expressivo e determina sua condição artística. A seu modo, transforma-se em um símbolo da resistência à violência tecnológica. "A primazia do objeto afirma-se esteticamente no 
caráter da arte como historiografia inconsciente, anamnese do subterrâneo, do recalcado, talvez do possível. A primazia do objeto, como liberdade potencial do existente respeito da

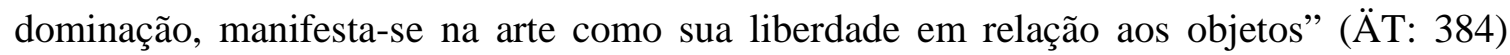
pragmaticamente constituídos. Por sua vez, essa liberdade em relação à dominação tecnológica revela-se na arte cinematográfica como uma tarefa que não pode ser realizada nem pelo sujeito, nem pela intersubjetividade, mas por esta instância paradoxal do objeto. A destituição da "falsa objetividade" da linguagem fossilizada, precisamente pelo alcance e pela capacidade dessa pseudo-objetividade para devir $a$ linguagem nas interações ordinárias da vida social, possui um amplo grau de resistência às intervenções críticas ou às avaliações externas do sujeito. Na indústria cinematográfica (e no conjunto da indústria cultural), comunicabilidade e Reklame identificam-se entre si, inclusive antes de pronunciar-se a favor ou contra alguma coisa. E é contra esta identidade que se desenvolve a dialética do cinema.

c) A dialética da modernidade cultural

Na reconstrução adorniana do processo do "devir arte" do cinema que acabamos de apresentar, resulta evidente que o conceito de cultura utilizado por ele não se fundamenta numa contraposição drástica e extrínseca entre "a cultura" e "o mundo tecnificado" da política e da economia. Neste aspecto, Habermas e Honneth têm razão. A teoria da sociedade de Adorno não pensa a cultura como uma dimensão social absolutamente, nem como um conjunto de práticas organizadas segundo modos diferenciais de ação comunicativa, entre os quais se desenvolveria a autonomia da arte. A composição do conceito indústria cultural é um claro exemplo desta posição, que resiste a aceitar a necessidade de uma conceituação dualista da sociedade. Porém, o que Habermas e Honneth descuidam é que com essa "ausência" a crítica de Adorno pretende desidealizar a esfera da produção e da circulação cultural no capitalismo tardio (pensando drasticamente sua conexão com a economia e a política), sem suprimir a particularidade de seu caráter simbólico e a intensidade da sua constituição conflitiva. Quando analisa a intervenção da técnica na cultura esta pretensão fica clara. Ele não procura achar a "resistência artística" à racionalidade técnica numa espécie de reserva ecológica de experiências, símbolos e 
discursos, que existiriam para além das relações de poder, na esfera das pretensões de validez do "mundo da vida" artístico. Pelo contrário, o que Adorno procura é descobrir de que modo a arte é capaz de interpretar os procedimentos técnicos que a constituem como "expressões" de um contexto social conflitivo, o qual solicita, pela modalidade do poder que se exerce nele (neutralização "interessada" da subjetividade, da história e da cultura), novas formas de compreensão das experiências, dos símbolos e dos discursos.

No tipo de análise cultural que Adorno pratica, não se reduz, então, o caráter conflitivo dos artefatos simbólicos e a ambivalência social dos meios técnicos de comunicação de massas a um problema que transcorre integralmente no momento da recepção, e que se materializa exclusivamente no nível do sentido do discurso. Pelo contrário, para Adorno a análise crítica da cultura no capitalismo tardio deve ser capaz de interpretar as relações de poder (e resistência) e a eficácia da racionalidade administrativa no nível das intervenções técnico-simbólicas dos próprios artefatos culturais. Não é casual, evidentemente, que o pequeno caso do cinema tenha servido para fazer esta crítica não "subjetivista", mas também não (abstratamente) "normativista", da modernização que conduz à hegemonia da indústria cultural.

Do duplo caráter da técnica no cinema podemos extrair algumas conclusões valiosas para nossa polêmica a respeito do conceito de cultura na Escola de Frankfurt, que nos serviram logo para fundamentar nossa tese, a partir da dialética negativa de Adorno, relativa à lógica das ciências sociais. Em tal sentido, vamos retomar esquematicamente, agora no contexto da concepção adorniana da cultura, a discussão com Habermas referida no conceito de "mundo administrado". Como temos assinalado, o cinema serve de exemplo paradigmático e limite, porque nele se reúnem de um modo particularmente revelador os problemas de diagnóstico com os problemas teóricos. A crítica habermasiana poder-se-ia resumir nas seguintes objeções:

1. No contexto da teoria da modernidade Adorno adota "uma perspectiva de crítica cultural que, frente às esperanças de Benjamin na potencialidade emancipatória da cultura de massas - naquele momento tratava-se 
fundamentalmente do cinema -, dá a seus escritos, e com razão, um tom cético." (Habermas, 1987a: 472-473)

2. Porém, ele não considera "o caráter radicalmente ambivalente do controle social exercido pelos meios de comunicação de massas". (473)

3. A causa profunda desta incompreensão da cultura na modernidade tardia está radicada "na assimilação dos novos meios de comunicação de massas ao valor de troca, apesar de as semelhanças estruturais entre eles não chegarem demasiado longe. Pois, enquanto o meio dinheiro substitui o entendimento linguístico como mecanismo de coordenação da ação, os meios de comunicação de massas continuam dependendo do entendimento linguístico”. (473)

4. O resultado desta retificação conceitual deveria permitir que "a questão de se uma cultura de massas, feita pelos meios de comunicação de massas, desenvolve forças tendentes a uma integração repressiva da consciência" dependa sobretudo de "saber se a comunicação encarrega-se de assimilar os homens por meio de seu isolamento, mas não pela determinação do grau da penetração das leis do mercado na própria produção cultural”. (473)

Habermas acha que pode liberar-se do problema exposto por Adorno e Horkheimer na ideia de "mundo administrado", por meio da distinção (quase ontológica) entre meios de controle social (orientados ao sucesso) e meios de interação linguística (orientados ao entendimento). Esta última distinção corresponde-se, logo, com a diferenciação nas sociedades modernas entre o campo de ação das instituições econômicas e políticas, e o campo da interação da esfera pública, donde se interpreta e se delibera autonomamente acerca do sentido destas. Ambas posições teóricas obrigam Habermas a afirmar que "as semelhanças estruturais" entre os produtos dos monopólios culturais e o meio dinheiro "não chegam demasiado longe". Ele prefere pensar a colonização do mundo da vida cultural, por meio do critério que determina em que grau a reciprocidade e a reversibilidade da comunicação entre o emissor e o receptor têm sido danificadas com a apropriação privada dos meios massivos de comunicação. Uma típica análise habermasiana determina o caráter 
ideológico da indústria cultural calculando o nível do bloqueio à comunicação social e a suas pretensões de validez diferenciadas. E considera as semelhanças estruturais entre a indústria cultural e as formas do poder econômico e político como secundárias ou nãorelevantes teoricamente.

A vantagem da crítica de Habermas ao determinismo do conceito de indústria cultural é que ela insere-se numa explicação sistemática. Frente às críticas empiristas, que se dedicam simplesmente a provar (estudando contextos muito restritos de recepção das obras) que o público dos grandes meios massivos de comunicação nunca perde sua autonomia e sua capacidade para "apropriar-se criativamente" dos produtos estandardizados da indústria, a posição de Habermas permite uma discussão mais precisa dos supostos e dos alcances desta polêmica. É sabido que existe toda uma geração de "cultural studies" que se baseia na refutação da crítica sociocultural de Adorno e Horkheimer, chamados por eles "teóricos do poder dos meios", e se dedicam, quase exclusivamente, a demonstrar a realidade do "poder das mediações sociais" na recepção e circulação dos artefatos culturais. ${ }^{110}$ Habermas e Honneth inscrevem-se nesta polêmica (entre o "poder dos meios" e o "poder das mediações") do lado dos cultural studies, mas tentam elevar essa crítica pontual à concepção determinista da cultura a uma posição teórica sistemática. É neste contexto que adquire valor a distinção entre os meios de controle social e os meios de interação linguística ou meios de comunicação, que vai servir para rejeitar a concepção de Adorno e Horkheimer. ${ }^{111}$

O ponto de partida de Habermas é eminentemente sociológico, e refere-se ao problema da coordenação da ação. A pergunta clássica é: como um agente consegue que outro continue dentro da interação e se comporte no sentido pretendido por ele sem que surja nenhum conflito que perturbe a sequência da ação? Para responder a esta pergunta, Habermas elabora uma revisão crítica da teoria sistemática de Talcott Parsons, a qual diferenciava dois tipos de ação por meio dos quais um agente pode condicionar a liberdade do outro para que este mantenha-se, no sentido pretendido, dentro da interação: atuar sobre a situação da ação do outro, ou atuar sobre as intenções do outro. Por sua vez, esse

110 Para uma discussão crítica desta problemática ver: Jameson, F. e Zizek, S., Estudios culturales. Reflexiones sobre el multiculturalismo, ed. Paidós, Bs. As., 1999.

${ }^{111}$ Ver Habermas (1987b): 368-402. 
condicionamento pode ser realizado por meio de sanções positivas ou negativas. $\mathrm{O}$ esquema simplificado de Parsons possui, então, duas variáveis e duas categorias para cada uma delas, de modo tal que surgem dele quatro tipos de regulação da interação e quatro tipos de meios para exercer essa regulação. Apresentamos o resultado da combinação entre elas no seguinte quadro, colocando entre parêntesis os respectivos meios:

\begin{tabular}{|l|c|c|}
\hline Sanções & A agente opera sobre & A situação de alter \\
\hline Positivas & Convencimento & Incitação de alter \\
& (influência) & (dinheiro) \\
\hline Negativas & Admonição & Intimidação \\
& (engajamento valorativo) & (poder) \\
\hline
\end{tabular}

Fundamentação dos meios em termos de uma teoria da ação, citado em: Habermas (1987b): 397

A crítica de Habermas a esta teoria funcionalista dos meios de interação social parte do receio frente à equiparação implícita que se faz entre "a forma estratégica e a forma consensual de exercer uma influência" (Habermas, 1987b: 396). A incitação e a intimidação podem ser consideradas intuitivamente como uma ação estratégica orientada à realização de um fim por parte de um agente particular, basicamente porque nessas interações o agente conta com a capacidade para sancionar positivamente (recompensa) ou negativamente (castigo) ao outro. Na forma de mandatos que devem ser cumpridos (para evitar um castigo) ou intercâmbios de bens que devem ser respeitados (para obter um beneficio), a intimidação e a incitação articulam-se perfeitamente com a institucionalização moderna dos meios poder e dinheiro. Ao dispor ambos tipos de interações de sanções que podem ser executadas com independência dos sentimentos, das opiniões ou das convicções morais de alter, pode-se conseguir o efeito desejado (que ele aceite o mandato do ego) de modo idêntico à forma pela qual a ação instrumental consegue que um meio material adéqüe-se eficientemente a um objetivo determinado. Nos termos da teoria da ação, pode falar-se, então, do poder e do dinheiro como constituindo meios em sentido estrito. Até aqui, Habermas acompanha a conceituação de Parsons. No entanto, ele vai criticar 
duramente a generalização - tipicamente funcionalista - desse modelo ao afirmar que o critério das sanções não é válido para os outros dois tipos de interação: o convencimento e a admonição. Segundo Habermas, "o conceito de sanção não pode ser aplicado às posturas de afirmação ou negação de pretensões de validez suscetíveis de crítica" (Habermas, 1987b: 397).

A diferença está radicada, para Habermas, em que, no caso da intimidação (poder) e da incitação (dinheiro), ego intervém na situação de alter para movê-lo a uma decisão, utilizando meios materiais ou verbais, mas orientado exclusivamente por seus próprios fins. Por isso ego pode entrar neste tipo de interações utilizando (ou padecendo o efeito) exclusivamente as sanções que funcionam como "motivações empíricas" para alter, seguro de que serão suficientes para o sucesso desta. A chave destas interações consiste em que tanto o meio poder quanto o meio dinheiro possuem uma "garantia" institucionalizada (a violência legítima/a convertibilidade do dinheiro), que permite a unilateralização das decisões no curso da interação. Pelo contrário, no caso do convencimento e da admonição essa unilateralização é impossível: "ego tem que falar com alter, com o objetivo de alcançar um acordo; aqui não existe outro caminho que não o entendimento", dado que, para convencer da existência de um determinado estado de coisas ou para assinalar a adequação moral de um comportamento, "ego não se pode orientar exclusivamente em função do êxito da sua ação, mas o que tem que procurar necessariamente é entender-se com alter" (Habermas, 1987b: 398). A explicação desta necessidade do entendimento recíproco estaria radicado na inexistência, no caso do convencimento e da admonição, de algum tipo de equivalente ao castigo ou à recompensa, ou seja, a inexistência de uma garantia institucional que possa funcionar como modo de uma "motivação empírica" da ação do alter. Habermas formula aqui uma das grandes distinções categoriais da sua teoria crítica. Segundo esta, quando a ação orienta-se a intervir sobre as intenções de alter (modificando suas opiniões ou fazendo uso dos valores compartilhados), não é possível pensar segundo o critério das sanções, dado que se existe a possibilidade de que a aceitação (ou rejeição) de uma pretensão de validez seja alcançada por meio de "motivações empíricas", então "estaríamos considerando essa aceitação com categorias que nem o próprio agente poderia levar a sério" (Habermas, 1987b: 398). Neste último caso, o agente 
não teria sido convencido da verdade de um determinado estado de coisas ou da justiça de uma determinada norma, mas teria sido obrigado ou incitado a aceitar essas posições.

No próprio uso da linguagem poder-se-ia constatar esta diferença. Enquanto as ações de convencer e admoestar utilizam verbos com os quais se deve poder fazer um uso ilocucionário da linguagem, pelo contrário, no caso das sanções, os enunciados só são utilizados para descrever os efeitos perlocucionários que podem provocar a não-realização do mandato. "As formas generalizadas de comunicação, como são a influência e o compromisso valorativo, exigem atos ilocucionários e dependem dos efeitos de vínculo que a linguagem tem quando é utilizada com o objetivo do entendimento. Pelo contrário, os meios de controle como são o dinheiro e o poder governam as interações por meio das intervenções de ego na situação de alter, ou seja, por meio de efeitos perlocucionários" (Habermas, 1987b: 399).

Esta relação diferenciada com a linguagem explica por que os meios de controle podem regular interações sociais substituindo o "entendimento linguístico", dando lugar a uma tecnificação das relações sociais, que é a que se rege no mundo social organizado pela racionalidade administrativa. Ela revela também o modo pelo qual, do outro lado desta tendência social da modernidade, desenvolvem-se as interações nas quais a comunicação não pode ser substituída, porque não existe nenhum meio institucionalizado que seja capaz de garantir a continuidade dessa interação, a não ser o próprio entendimento linguístico. Nesta última categoria Habermas situa os meios massivos de comunicação, refutando assim a relação entre poder e obediência contida no conceito de indústria cultural. Ele demonstra a falsidade dessa concepção, ao demonstrar que nenhum meio moderno de comunicação (cinema, rádio, TV etc.), sem importar o grau de mercantilizacão de seus produtos, pode intervir diretamente sobre a situação do seu público, nem utilizar outros meios institucionalizados para convencê-lo que não sejam os diversos usos ilocucionários da linguagem. Ou seja, dado que nenhum meio de reprodução técnica da cultura conta com meios para sancionar (positiva ou negativamente) ao receptor, nem para unilateralizar as decisões de aceitação ou rejeição de uma determinada pretensão de validez, deve afirmar-se enfaticamente que "não existem semelhanças estruturais" entre eles e os meios de controle dinheiro e poder, tal qual o propõe o conceito de indústria cultural. 
A consequência desta reformulação no plano da teoria é imediata. Com esta análise, a comunicação linguística passa a ocupar o papel de diferenciador central dos tipos de interação social, finalmente clarificados pela evolução social representada pelo processo de modernização cultural. Por um lado, temos as interações que constituem a reciprocidade dos pontos de vista e regulam a coordenação da ação por meio da renovação permanente do entendimento linguístico, que só se faz efetiva na ação comunicativa entre os participantes. Por outro lado, temos as interações que substituem à formação linguística do consenso por meio da institucionalização de sanções que servem para garantir a continuidade da interação e para regular unilateralmente seu sentido, gerando por esses meios uma tecnificação do "mundo da vida". A partir desta distinção, Habermas vai propor que as teses referidas à tecnificação da cultura (quando se fala do poder simbólico dos monopólios culturais ou da sua força de persuasão sobre os indivíduos), só podem ser interpretadas como o resultado de um uso metafórico (ou seja, não teórico) do conceito de poder e do conceito de técnica. Como meios, os aparelhos de comunicação de massas não podem em nenhum caso substituir o entendimento linguístico como forma do vínculo efetivo entre os participantes, devendo ser interpretada sua distância em relação a eles e às formas mais complexas de arguição e crítica como uma simplificação e uma "especialização dos processos linguísticos de formação de consenso", que se faz para "liberar os atos de fala das restrições espaço-temporais que lhes impõe o contexto, de tal modo a pô-los à disposição de contextos multiplicados" (Habermas, 1987b: 401).

Contrariando esta posição habermasiana, enormemente difundida, cremos ter demonstrado, em princípio, que o conceito de indústria cultural de Adorno e Horkheimer não se baseia na determinação do grau de penetração das leis do mercado na cultura, mas na subsunção real da cultura (a arte, mas também a moral, a ciência, a religião) ao capital. É neste ponto que os problemas de diagnóstico juntam-se com os problemas teóricos. Segundo nosso entender, Adorno e Horkheimer, sim, demonstraram que existem semelhanças estruturais entre os "produtos simbólicos" da indústria cultural e os meios de controle social, como são o dinheiro ou o poder. O que acontece é que elas não se dão onde Habermas (e Honneth) pretende achá-las. Pode-se interpretar, de fato, este mal-entendido, entre a crítica de Adorno e Horkheimer e a saída teórica habermasiana, como um elemento sintomático dos desafios que este último prefere evitar, no preciso momento em que garante 
tê-los superado. Esta operação teórica está construída, inteiramente, por aquilo que nós chamaremos de "ideologia da transparência".

A primeira observação que tem que ser colocada diz respeito à concepção da totalidade social envolvida na ideia de mundo administrado. Os críticos da teoria da sociedade de Adorno e Horkheimer interpretam com frequência o conceito de indústria cultural como um indício claro de um reducionismo teórico, que consistiria em identificar (sem fundamentos empíricos) a estrutura e a lógica de funcionamento da economia com a estrutura e a lógica de funcionamento da política e da cultura. Com esta noção de totalidade social, por exemplo, poder-se-ia traçar uma identidade linear e absoluta entre a "máquina morta" do moderno sistema de produção, a "máquina viva" do regime de dominação burocrático e a "máquina simbólica" dos monopólios culturais. Contudo, o que surpreende do ensaio acerca da indústria cultural é que, contrariando essas leituras superficiais, não se pode encontrar nele este modelo de totalidade. No caso que temos analisado neste capitulo, temos constatado que a tecnificação cultural não opera sobre os indivíduos seguindo os mesmos critérios e procedimentos que utiliza a racionalidade administrativa na burocracia e na economia. Não existem na análise da indústria cultural nem a hierarquia funcional, nem os controles, nem a regulação da informação que vigora no "aparelho burocrático". ${ }^{112}$ Contra o que se costuma pensar, para Adorno e Horkheimer a indústria cultural não opera ideologicamente sobre seu público por meio dá imposição de mandatos, regulamentos fixos ou padrões de comportamento. A subsunção real da cultura ao capital operada pela máquina simbólica não implica para eles uma identidade estrutural entre ela e a máquina burocrática. De fato, elas diferenciam-se para Adorno e Horkheimer num sentido próximo ao reclamado teoricamente por Habermas, ou seja: não existe, no caso da indústria cultural, a capacidade para impor a aceitação de um sentido determinado por fora do âmbito da comunicação. Por isso, resulta completamente falso afirmar que a indústria cultural é pensada a partir da capacidade para exercer um tipo de domínio que "substitui o entendimento linguístico como mecanismo de coordenação da ação”. Quem refuta esta tese não está refutando as teses de Adorno e Horkheimer. Como temos analisado no caso da aparência de transparência da técnica de reprodução cinematográfica, os mecanismos

\footnotetext{
${ }^{112}$ Ver supra p. 24 e ss.
} 
ideológicos da indústria cultural não funcionam para eles suprimindo, dificultando ou obscurecendo a comunicação, mas, pelo contrário, esses mecanismos operam ideologicamente enquanto se transformam em um gigantesco aparelho de facilitação $e$ promoção da comunicação universal. A utilização ideológica do dispositivo cinematográfico tem que ser considerada como eminentemente ilocucionária, dado que ela só configura o sentido do exibido para facilitar pragmaticamente sua transmissibilidade e compreensão, sem pretender nenhum outro efeito ("perlocucionário"). Por isso, será na comunicação e no entendimento linguístico que Adorno e Horkheimer vão achar as semelhanças entre os produtos da indústria cultural e os outros meios de controle social, e não numa interrupção violenta ou interessada dela. Aqui vigora, evidentemente, a discordância fundamental com Habermas.

O final do ensaio acerca da indústria cultural contém um pequeno - e pouco comentado - tratado de filosofia da linguagem, que toma em consideração os efeitos fundamentais que produzem as modernas máquinas simbólicas sobre a linguagem. Ali se indicam as semelhanças estruturais com o dinheiro e o poder que a exposição de Habermas obscurece. Por um lado, a ideia de que a interação comunicativa desenvolve-se sem nenhuma estrutura de sanções é desmentida pela lógica de funcionamento dos produtos da indústria cultural, com efeitos que podem ser generalizados. O que acontece é que, efetivamente, não existem neles sanções externas que possam funcionar como um limite e uma garantia visível, capazes de resolver conflitos ou complexidades da interação. Porém, existem na lógica da comunicação limites invisíveis dentro da sua ilimitada liberdade.

O primeiro deles é a ameaça de ser excluído da comunicação. Esse limite não é externo, nem obriga do mesmo modo que a violência ou o dinheiro, mas é capaz de constituir-se, como eles, em uma poderosa "motivação" que leva a aceitar, para além das razões esgrimidas, a pretensão de validez de um enunciado qualquer. Adorno e Horkheimer utilizam uma passagem da Democracia em América, de Tocqueville, para ilustrar a eficácia e o nível no qual opera este tipo de sanção comunicativa: "O amo já não diz: deves pensar como eu ou morrer. Ele diz: tu és livre para não pensar como eu, tua vida, teus bens, tudo será protegido, mas a partir deste momento tu és um estrangeiro entre nós". 113

\footnotetext{
${ }^{113}$ Tocqueville, A., De La démocratie em Amérique, Paris, 1864, II, p. 151. Citado em (DA): 155.
} 
Devemos notar que é o uso da "aparência de transparência", tecnologicamente implementada, o que produz a possibilidade deste tipo de sanções. Dado que as operações simbólicas da indústria cultural desvanecem-se ao assumir a forma de um puro meio de comunicação (lembremos que até Habermas apresenta-as como meios que "liberam os atos de fala das restrições espaço-temporais que lhes impõe o contexto"), quem duvida da forma de falar, do ângulo do que aparece, dos ritmos em que se sucedem as imagens e os discursos, dos contrastes que são evitados no quadro da câmera etc., não duvida de uma posição discursiva, mas duvida da própria possibilidade da comunicação. E, em tal sentido, são eles mesmos os que, ao rejeitar o mecanismo, colocam-se por fora das condições de possibilidade do circuito comunicativo.

Para compreender esta situação, devemos equiparar aquilo que Adorno e Horkheimer denominaram evidência fotológica (photologische Beweis) dos artefatos simbólicos da indústria cultural com aquilo que, na teoria dos atos de fala, denomina-se transfundo aproblemático de pressupostos e valores compartilhados. Este transfundo define-se negativamente como uma série de acordos básicos, que fazem possível a comunicação, mas sem fazer parte daquilo que está sendo apresentado ou discutido pelos falantes no caso particular. É um marco que estrutura e dá sentido aos diversos contextos comunicativos, sem participar explicitamente deles. Na teoria dos atos de fala, este transfundo de acordos implícitos define-se pela sua estabilidade, que colabora na função de estabilizar as posições recíprocas dos falantes. Porém, ninguém pode ser expulso de uma interação comunicativa meramente por questionar aquilo que até esse momento permanecia como aproblemático. O que a teoria prevê nestes casos é uma ampliação, uma complexização da comunicação ou uma resolução externa da controvérsia por meio do contexto institucional, mas não uma exclusão imediata e interna à própria comunicação. Este é, contudo, o desafio que a indústria cultural coloca à teoria pragmática do discurso, o qual, a meu modo de ver, ela não pode resolver. No caso da "evidência fotológica" da qual falam Adorno e Horkheimer, estamos diante de um transfundo simbólico que aparece eficazmente na forma de uma realidade não-simbolizada. $\mathrm{Na}$ condição de pura "reprodução" fidedigna do mundo, essa evidência de fundo, facilitada tecnologicamente, não é suscetível de controvérsia ou clarificação racional, dado que ela não se inclui em pressupostos culturais ou valores compartilhados, mas trata-se das pretensões da 
reprodução da "realidade mesma", da faticidade nua. Os enunciados particulares da indústria cultural podem ser, sim, discutidos, julgados ou rejeitados, mas o marco tecnosimbólico da máquina cultural está blindado contra qualquer objeção. Ele é aproblematico e não problematizável dentro da comunicação. Quem não se quiser expressar no ritmo do rádio e da TV, quem suspeitar da fantasia de uma comunicação universal "livre de distorções" que a transparência tecnológica promove não vai ser violentado, nem estimulado a mudar de parecer. Ele simplesmente vai ser considerado como alguém que decidiu colocar-se fora da língua que permite a comunicação entre os homens: "um estrangeiro entre nós”. Esta ameaça é um elemento constitutivo da indústria cultural, a qual se faz efetiva cotidianamente ao modo de uma sanção por meio da exclusão da comunicação. Por esta razão, ela constitui-se na primeira semelhança estrutural entre os produtos da indústria cultural e o meio de controle "poder", que Adorno e Horkheimer têm sublinhado no interior do conceito de "mundo administrado".

Se a primeira semelhança entre os meios de comunicação e os meios de controle pode ser considerada como uma sanção negativa, a segunda semelhança deve ser considerada como uma sanção positiva, que se exerce em diversos contextos sociais. Tratase agora daquilo que a indústria cultural faz positivamente na comunicação e por meio da comunicação, sobre a experiência subjetiva e coletiva. A tese de Adorno e Horkheimer refere-se ao processo de racionalização da linguagem que a "publicidade" reproduzida tecnologicamente estimula: "Quanto mais perfeita resulta a fusão entre a linguagem e a comunicação, tanto mais se tornam as palavras de portadores substanciais do sentido (substantiellen Bedeutungsträgern) em meros signos carentes de qualidade; quanto mais pura e transparente é a transmissão do pensado, tanto mais as palavras tornam-se impenetráveis" (DA: 187). Este é o percurso, evidentemente, daquilo que Adorno e Horkheimer têm pensado como a dialética da demitologização ilustrada da linguagem. Na exigência obstinada de transparência no uso das palavras, que procurava evitar a confusão fetichista entre coisa e palavra, as palavras terminam condenadas a uma função puramente designativa, por meio da qual são fixadas à coisa de um modo ainda mais rígido que aquele que existia no pensamento mágico. ${ }^{114}$ Nesse processo tanto o objeto quanto a palavra são

\footnotetext{
114 "Hatte das Wort vor seiner Rationalisierung mit der Sehnsucht auch die Lüge entfesselt, so ist das rationalisierte zur Zwangsjacke geworden für die Sehnsucht mehr noch als für die Lüge. Die Blindheit und
} 
afetados, dado que "em vez de levar o objeto à experiência, a palavra purificada o expõe como caso de um momento abstrato, e faz que o resto, excluído da expressão por um dever desapiedado de claridade, desapareça por completo, também da realidade" (DA: 188). Esta é a causa do paradoxo da comunicação que organiza a indústria cultural: quanto mais preciso, transparente e universal é o uso da linguagem, mais impenetráveis e opacas tornam-se as palavras para expressar ao sujeito sua história e suas tradições culturais.

Contra o que afirma a crítica de Habermas, podemos constatar como na análise de Adorno e Horkheimer tampouco quando a máquina cultural trabalha positivamente funciona suprimindo ou obscurecendo a interação comunicativa. De fato, ela estimula a comunicação horizontal entre seu público, por meio de uma purificação da linguagem que facilita a participação, no mesmo movimento no qual torna o sujeito inexpressivo, produzindo assim uma situação paradoxal em relação a suas pretensões racionais. Ao distanciar as palavras purificadas da experiência dos sujeitos, elas cobram outra vez uma força sobrenatural, sem que o entendimento linguístico entre os participantes possa fazer nada para suprimir a reprodução desses fetiches da tecnologia cultural. Neste tipo de comunicação juntam-se facilmente, então, a frialdade em relação às palavras com a exaltação dos símbolos-fetiches comunitários, sem que seja necessário compreender com propriedade, em nenhum dos dois casos, o significado linguístico das expressões que se utilizam. ${ }^{115}$

Porém, esta destruição e esta fossilização da linguagem constituem a sanção positiva que a indústria cultural promove: a possibilidade de contar com uma linguagem que vincula eficientemente aos homens entre si e a eles com as coisas, sem que seja

Stummheit der Daten, auf welche der Positivismus die Welt reduziert, geht auf die Sprache selber über, die sich auf die Registrierung jener Daten beschränkt. So werden die Bezeichnungen selbst undurchdringlich, sie erhalten eine Schlagkraft, eine Gewalt der Adhäsion und Abstoßung, die sie ihrem extremen Gegensatz, den Zaubersprüchen, ähnlich macht." Adorno e Horkheimer, (DA): 188.

115 “Das blinde und rapid sich ausbreitende Wiederholen designierter Worte verbindet die Reklame mit der totalitären Parole. Die Schicht der Erfahrung, welche die Worte zu denen der Menschen machte, die sie sprachen, ist abgegraben, und in der prompten Aneignung nimmt die Sprache jene Kälte an, die ihr bislang nur an Litfaßsäulen und im Annoncenteil der Zeitungen eigen war. Unzählige gebrauchen Worte und Redewendungen, die sie entweder überhaupt nicht mehr verstehen oder nur ihrem behavioristischen Stellenwert nach benutzen, so wie Schutzzeichen, die sich schließlich um so zwangshafter an ihre Objekte heften, je weniger ihr sprachlicher Sinn mehr erfaßt wird." Adorno e Horkheimer (DA): 189. 
necessária, para que essa linguagem possa ser utilizada, uma compreensão trabalhosa e apropriada de seu significado linguístico. Para além das contradições que puder provocar semelhante racionalização da linguagem, a praticidade para referir-se às coisas e a exaltação de um espírito comunitário abstrato, sem fricções ou tensões, garantem a continuidade das interações sociais de maneira semelhante ao modo de operar do dinheiro. Esta é a incitação por meio da comunicação que a indústria cultural não pode deixar de efetuar cotidianamente.

A combinação da sanção positiva (a racionalização da linguagem) com a sanção negativa (a ameaça de exclusão do circuito comunicativo) no plano da comunicação social é utilizada pela indústria cultural para motivar a aceitação de seus conteúdos, num processo que poderia ser considerado rigorosamente como uma tecnificação da cultura. Esta tecnificação da cultura é a que justifica, contra os diagnósticos e as críticas de Habermas e Honneth, a validez e a atualidade do conceito de mundo administrado. Temos que sublinhar, contudo, que as semelhanças estruturais entre a economia, a política e a cultura que esse conceito estabelece não implicam nenhuma identidade ou reducionismo de alguma dessas esferas (a cultura) nas outras (a economia e a política). O conceito de indústria cultural não é, portanto, o instrumento teórico encarregado de verificar a presença da mesma racionalidade e da mesma modalidade da dominação nas diversas dimensões em que pode ser distinguida a sociedade. Já no pequeno exemplo relativo ao cinema tivemos ocasião de demonstrar que são esses tipos de concepções acerca da totalidade social os que Adorno critica, dado que são eles os que obstruem, conformando uma poderosa ideologia na teoria, a distinção do duplo sentido da técnica na produção cultural. Nem a teoria da sociedade nem a teoria da cultura de Adorno podem ser confundidas com essas posições reducionistas. O que acontece é que com o conceito de indústria cultural Adorno e Horkheimer procuram, sim, determinar criticamente a articulação entre a economia, a política e a cultura na modernidade tardia, interferindo necessariamente nas mistificações que defendem a autonomia absoluta (ou programática) das diversas esferas sociais.

Uma autêntica interpretação crítica desta problemática deveria evitar explicar a irritação que provocam o conceito de indústria cultural e a ideia de mundo administrado por meio das teses que se referem, obsessivamente, ao reducionismo teórico e à invisibilização do caráter conflitivo da cultura. Não são essas as causas profundas da irritação, da tensão, 
que provoca nos debates sobre a cultura a teoria de Adorno e Horkheimer. O problema consiste em que eles demonstram que a particularidade histórica e a especificidade simbólica da dominação do capital na modernidade tardia não se exercem por meio da substituição da comunicação, mas através dela e por meio dela. Este é o elemento irritante do conceito de indústria cultural: a afirmação de que na modernidade tardia a matriz da tecnificação da cultura realiza-se através da comunicação livre, universal e transparente. Nela e através dela se organizam as sanções que vão regular as interações culturais (que determinam, por sua vez, as outras relações "simbolicamente mediadas" da política e da economia) e nela e através dela se constrói a ideologia que vela o funcionamento do sistema. É no meio da comunicação que os sujeitos que participam são potencial ou efetivamente sancionados e punidos, e é por meio dela que as interações empobrecem-se e submetem-se aos centros que dirigem a reprodução da cultura.

Na nossa análise da interpretação de Adorno a respeito do cinema insinuamos algo que agora gostaríamos de afirmar com maior ênfase. Quando ele analisa o uso ideológico das novas tecnologias de reprodução da arte destaca duas determinações: a "aparência de transparência" (que promove) e a fusão da linguagem com a "publicidade" (que produz). Poder-se-ia pensar que Adorno assinala aqui, com a denúncia de seu caráter ideológico, a ausência de ambos atributos no cinema: transparência e linguagem pública. A crítica teria por objeto a falsa publicidade (Reklame) que constrói o dispositivo tecnológico do cinema, que passaria a ser interpretada como uma paródia da autêntica "publicidade" (Öffentlichkeit). Porém, temos insistido até aqui em que não é essa a análise de Adorno. Podemos agora fundamentar melhor nossa interpretação. Para Adorno o momento ideológico do cinema (e com ele da indústria cultural toda, por isso o valor estratégico deste "pequeno exemplo") não consiste em que ele falseia ou realiza parcialmente as pretensões de validez de uma comunicação aberta e transparente, mas, pelo contrário, em que ele realiza esses princípios "bem demais", de tal modo que é capaz de gerar com eles o que temos chamado de "ideologia da transparência".

Como temos mostrado no caso do cinema, a "aparência de transparência" não é uma mera ficção ou um simples engano que substitui uma coisa por outra. Tanto ela quanto a ideia do caráter público e aberto dos produtos simbólicos da indústria cultural "aparecem" efetivamente, realmente, no dispositivo cinematográfico. No entanto, na análise do cinema 
de Adorno são esses atributos os que provocam a fossilização da linguagem, contra a qual opera o autêntico devir arte das práticas simbólicas. Com este paradoxo da transparência e da publicidade Adorno situa criticamente a comunicação num modelo de dialética negativa. No centro deste modelo de análise, a comunicação não deve ser criticada exclusivamente por tratar-se de uma "ideia" em si mesma boa, emancipadora, que, porém, engana os homens ao projetar uma forma de intersubjetividade que não existe efetivamente na realidade. Ela deve ser criticada também (e fundamentalmente) porque ao realizar-se cotidianamente no sistema da indústria cultural, organiza formas repressivas de interação social, que neutralizam a experiência subjetiva, a história e as tradições culturais.

Se retomarmos a partir desta problemática nossa reconstrução completa da análise adorniana do cinema, poderemos extrair uma série de conclusões provisórias a respeito de seu conceito de cultura e a respeito da vinculação dele com o problema da fundamentação da teoria crítica:

1. A subsunção real da cultura ao poder do capital não depende da substituição da comunicação como meio regulador das interações sociais. Contudo, a articulação entre a economia capitalista e a modernidade cultural, sim, pode ser pensada como um processo de tecnificação da cultura (pelo qual está fundamentada a pertinência do conceito de indústria cultural).

2. Os mecanismos de controle do processo de tecnificação da cultura não podem ser conhecidos nem por meio da análise crítica dos atos de fala, nem da investigação dos usos das sanções extralinguísticas, anunciadas por meio da primazia do uso perlocucionário da linguagem. Isso se deve ao fato de que os mecanismos de controle da tecnificação da cultura trabalham em outro nível: como capacidade para fossilizar a linguagem (sanção positiva) e como ameaça de expulsão do circuito comunicativo (sanção negativa) que produzem as tecnologias da comunicação, utilizadas ilocucionariamente pelos monopólios culturais.

3. Numa atualidade social marcada pela tecnificação da cultura, a interação comunicativa não pode servir de critério absoluto para a crítica cultural, nem se estabelecer como paradigma da liberdade na teoria da sociedade. A causa desta 
impossibilidade está radicada no fato de seus principais atributos, a transparência e a publicidade, coincidirem massivamente com os procedimentos da indústria cultural.

4. A teoria crítica da sociedade vê-se forçada a desconfiar da diferença entre as interações motivadas empiricamente pelo dinheiro e o poder e aquelas conseguidas por meio do entendimento linguístico em relação a pretensões de validez suscetíveis de crítica. Ambos tipos de interações devem poder ser conceitualmente considerados pela teoria crítica como formas de neutralização das experiências subjetiva, social e cultural.

Frente a esta última conclusão poderíamos reencontrar novamente a denúncia que Habermas e Honneth fizeram das estratégias teóricas da "primeira geração da Escola de Frankfurt": ao tentar criticar a racionalização social eles dissolvem a distinção entre faticidade e validez, que é a distinção chave para não cair nas redes da "racionalidade funcionalista" e da "teoria unilateral do poder". Porém, temos agora outros elementos para responder a essa demanda. O primeiro deles toma em consideração a arte (e a crítica de arte) como forma de conhecimento não-transcendente dos efeitos do processo de racionalização social. No tipo de crítica que Adorno fez do cinema temos demonstrado a possibilidade de uma crítica "não-elitista" da modernidade cultural, que evita tanto a explicação funcionalista quanto a posição normativista. Para Adorno, a concepção funcionalista da cultura reduz e anula o caráter conflitivo da técnica na produção simbólica. Por outro lado, a posição dualista, que depende de uma rígida distinção entre faticidade e validez (impraticável na modernidade tardia), desconhece a eficácia das tecnologias da comunicação. O outro modelo de crítica cultural repete a estratégia que Adorno denominou "primazia do objeto" (Vorrang des Objekt).

Os diversos significados que assume "o objeto" nesta estratégia delineiam um modelo de interpretação da cultura que resulta particularmente adequado para lidar com o processo de fossilização da linguagem que se observa na modernidade tardia. Neste sentido, Adorno fala da primazia do objeto em, ao menos, dois sentidos diferentes. Num plano metodológico geral a primazia do objeto implica em interpretar o sentido das imagens e dos discursos reinscrevendo neles os efeitos simbólicos das técnicas que os fazem possíveis e os reproduzem socialmente. $\mathrm{O}$ modelo desta estratégia de interpretação desloca a primazia 
que assume a relação intersubjetiva na tradição hermenêutica (e seus desdobramentos "humanizadores" dos artefatos da indústria cultural). A primazia do objeto desvenda a falsidade da concepção que pensa a produção do sentido como algo que transcorre exclusivamente entre um sujeito que cria e outro sujeito que compreende (postulando teoricamente assim uma relação que parte sempre de um sujeito e se dirige sempre a outro sujeito). Entre eles trabalham sobre a ordem simbólica, "objetivamente" na comunicação, as operações que esta perspectiva interpretativa procura repor no processo de deciframento do sentido.

Por outro lado, no plano específico da crítica da arte a primazia do objeto significa a primazia da negatividade que faz de um objeto um objeto estético. O interessante de nosso "pequeno exemplo" do cinema é que ele revela que Adorno não pensa a negatividade da arte como algo transcendente ou "esotérico" em relação à cultura que organiza cotidianamente as interações entre os homens. Pelo contrário, essa negatividade (que Adorno chama "impura") só aparece como resistência ou oposição na linguagem e nos meios que regulam a comunicação ordinária entre eles. Na análise adorniana do uso artístico da montagem cinematográfica esta relação aparecia representada por diversas figuras negativas: imagens não-convergentes, objetos não-intencionais, objetos nãocomunicativos, objetos invisíveis. Todas estas figuras procedem do deslocamento do sentido (em constelação) que a montagem tem que produzir $n a$ linguagem fossilizada pelo processo de modernização, para forçar desse modo o devir arte do cinema. A primazia do objeto significa, então, na crítica da arte, o privilégio, na análise e na interpretação, dos momentos nos quais a obra entra em conflito com as exigências do funcionamento da linguagem comunicativa, fazendo aparecer assim um objeto simbólico não-idêntico em relação a elas, no meio da linguagem que produz e garante a identidade dos sujeitos e das coisas. No próximo capitulo tentaremos aprofundar a indagação desta relação negativa entre a arte e a linguagem comunicativa, assim como seu significado para nossa problemática teórica geral. O que importava aqui era ressaltar que a estratégia que Adorno elabora para compreender a dialética da modernidade cultural pode, sim, interpretar criticamente a tecnificação da cultura, sem cair nas redes da racionalidade funcionalista, nem das idealizações normativistas. 


\section{Capitulo 4: O olhar de Apolo \\ A arte como momento negativo na constituição da esfera pública}

A arte é a antítese social da sociedade

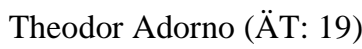

Na história do conceito de esfera pública (Öffentlichkeit), que tem adquirido uma importância crescente na discussão acadêmica no que se refere aos dilemas da comunicação e à cultura das sociedades contemporâneas, a obra de Jürgen Habermas continua sendo uma fonte imprescindível. Foi ele quem deu um caráter abrangente ao conceito (que se pode utilizar no estudo, não só da esfera pública política, mas também da literária, científica, moral etc.) e quem elaborou, a partir desse conceito ampliado, uma perspectiva de filosofia social consistente (sua conhecida Teoria da Ação Comunicativa). Já em seu livro História e crítica da esfera pública Habermas tinha tentado oferecer um estudo histórico que servisse de paradigma para as investigações empíricas da esfera cultural do capitalismo tardio e que permitisse dar conta de sua complexa articulação com o mercado e o Estado. Este trabalho continuava criticamente, como indicamos nos capítulos precedentes, as investigações da primeira geração da escola de Frankfurt a respeito da lógica da cultura de massas e de sua dependência dos novos agentes econômicos monopólicos. Em termos teóricos, o conceito de esfera pública, entendido como o espaço no qual os cidadãos podem comunicar-se entre si e ocupar-se dos temas de interesse geral sem ser coagidos (Habermas, 1990), permitia a Habermas uma fundamentação histórica de seu paradigma, baseada na experiência da politizada e crítica opinião pública (öffentliche Meinung) das sociedades burguesas em sua etapa liberal (séculos XVIII e XIX).

Porém, esta crítica de Habermas não tem apenas uma significação histórica. Ela dirige-se também, como já destacamos ( $C f r$., capitulo 1), contra as insuficiências teóricas que ele encontra no conceito de indústria cultural de seus antecessores. Num sentido superador, o conceito de esfera pública permite criticar a degradação e a manipulação da vida cultural nas sociedades modernas evitando, ao mesmo tempo, os diagnósticos sombrios que desfiguram a complexa realidade das disputas simbólicas entre interesses opostos que podem existir no sistema cultural das sociedades democráticas (quando estas 
garantem normativamente a liberdade de expressão e de acesso aos espaços de deliberação coletiva). De fato, este foi um dos argumentos centrais que o levaram, vinte anos depois da publicação do seu trabalho a respeito da esfera pública liberal, à sua própria Teoria da Ação Comunicativa, na qual Habermas tenta superar o que considera o grande erro de Adorno e Horkheimer, quer dizer: o fato de haver-se concentrado na construção de uma filosofia da história da dominação total do indivíduo, descuidando das possibilidades da ação racional e da resistência ao poder que surgem da construção de valores, tanto por parte dos distintos grupos sociais que participam da vida moderna, quanto dos indivíduos que os integram.

Isto explica por que, quando Habermas quer pensar um conceito de ação racional que esteja à altura das dificuldades mas também das potencialidades das sociedades modernas avançadas, ele precisa criticar o conceito de indústria cultural como excessivamente determinista e simplificador. O desenvolvimento do conceito de esfera pública, com seus diferentes campos de aplicação, permite realizar esta dupla tarefa, já que é na própria esfera pública onde se dão as tentativas de manipulá-la, instrumentalizá-la e pô-la a serviço de interesses privados, e é nela que se manifestam os esforços por expressar outras opiniões e outros interesses. Na tese de Habermas, estes esforços, realizados por grupos que resistem à privatização das discussões referidas no interesse geral, abrem continuamente, pela própria lógica interna da esfera pública, o jogo deliberativo.

Como se sabe, este conceito de esfera pública suscitou múltiplas leituras e críticas, relativas fundamentalmente a seu valor explicativo e sua capacidade para dar conta (ou não) da lógica por meio da qual são gerados e se exprimem os conflitos sociais contemporâneos. ${ }^{116}$ Porém, o ideal de liberdade comunicativa postulado por Habermas encontrou as maiores dificuldades, por motivos que nos interessará logo analisar, ao ser confrontado com a experiência estética e a produção e circulação da arte. Neste caso a controvérsia torna-se mais intensa e o conflito revela elementos sintomáticos. Com efeito, o paradigma que se baseia no conceito de esfera pública defende uma relação de complementaridade positiva entre as diversas esferas autônomas da cultura, assim como entre elas e as práticas do "mundo da vida" dos sujeitos, que não se ajusta à experiência histórica no campo da arte. Essa relação de complementaridade positiva que o conceito de esfera pública postula entra necessariamente em conflito com as expressões radicais da arte

\footnotetext{
${ }^{116}$ Ver Calhoun, C. (Org.), Habermas and the Public Sphere, ed. MIT Press, Massachusetts, 1994.
} 
moderna e contemporânea, que são precisamente as que permitem determinar enfaticamente o conceito de autonomia da arte que Habermas diz querer defender no interior de seu paradigma explicativo. No entanto, apesar desta pretensão, a interpretação teórica de Habermas não tolera nenhum conteúdo legítimo na esfera artística que não seja subsumível a um critério de formação cultural que resulta, a todas luzes, de difícil atualidade. Num sentido contrário ao indicado por esta formulação habermasiana, Christoph Menke tem desenvolvido uma interpretação da autonomia da arte moderna que se baseia na demonstração de seu caráter essencialmente negativo. ${ }^{117}$ Segundo esta perspectiva, a singularidade da experiência estética caracteriza-se por promover uma negação eficaz das outras formas socialmente válidas de produção de sentido, e não por complementá-las. O confronto entre as perspectivas de Habermas e Menke sustenta-se, evidentemente, em suas diferenças em relação a Adorno e na divergência a propósito dos dilemas que a arte enfrenta no mundo contemporâneo.

Para Habermas, a arte que não queira ser estéril deve interatuar positivamente com as outras esferas culturais (moral, ciência, política, religião), colaborando assim, desde a autonomia de seus valores e procedimentos, no processo da livre formação da identidade dos sujeitos. O lugar da arte no intercâmbio simbólico é, com efeito, formalmente diferente daquele da moral ou da ciência (pois ela não depende da univocidade dos conceitos e é portadora de uma riqueza perceptiva e afetiva que falta às outras esferas), mas converge com elas na constituição de uma intersubjetividade que tem por finalidade a identificação recíproca dos sujeitos, no marco de valores compartilhados. Habermas estabeleceu sempre uma relação clara e estreita entre a função da interação positiva das esferas de valor diferençadas da modernidade e a função da constituição da identidade dos sujeitos. Ele tenta resolver desse modo o dilema weberiano, que pensava em termos trágicos a diferenciação das ordens de validez da razão. A esfera pública seria, precisamente, o espaço simbólico no qual ambas funções poderiam ativar-se segundo critérios de reciprocidade, liberdade e igualdade. Enriquecer criticamente esse marco axiológico e fornecer o elemento expressivo ausente nas outras esferas culturais é, para Habermas, a autêntica função da relação positiva na qual a arte deve inserir-se, completando assim sua existência autônoma.

\footnotetext{
${ }^{117}$ Ver Menke, Ch., La Soberanía del arte, la experiencia estética en Adorno y Derrida, Madrid, Visor, 1997.
} 
Contrariando as teses do paradigma da ação comunicativa, Menke propõe uma interpretação da potencialidade da arte nas sociedades contemporâneas que depende exclusivamente da ideia de interação negativa. Para Menke, a negatividade transforma-se em um conceito chave para pensar a existência e as potencialidades da autonomia da arte no mundo contemporâneo, razão pela qual a obra de Adorno adquire uma renovada relevância. A situação paradoxal na qual Adorno situou a arte - na sua Teoria Estética - ao compreendê-la como um momento antissocial da sociedade, confronta-se abertamente com a ideia de complementaridade positiva das esferas de valor e com a teleologia que põe a arte a serviço do princípio de individuação e identificação do sujeito. Menke descobre que a difícil experiência da autonomia da arte não pode, sob nenhum aspecto, ser compreendida a partir da relação positiva entre ela e as outras esferas culturais. Com esta tese polêmica, a arte transforma-se num momento negativo da própria constituição da esfera pública das sociedades modernas, que tende a desarticular internamente a estrutura de suas pretensões de validez diferenciadas. Para comprovar a legitimidade desta interpretação, que se baseia em Adorno, várias aclarações devem ser feitas em relação ao potencial explicativo da negatividade como chave para compreender a experiência estética e seus efeitos.

O que deve ser indagado, em primeiro lugar, é a potencialidade teórica da ideia de negatividade para fundamentar a autonomia estética. Como se sabe, esta posição define polemicamente a experiência estética por meio da oposição entre o estético e o extraestético. Por isso, para corroborar esta posição, deve-se analisar o processo de autonomização da arte no sentido de uma dupla negação: por um lado, como negação do discurso artístico tradicional (ao qual critica pelo seu "valor cultual"); mas, numa segunda negação, esse processo também deveria poder ser constatado como oposição e resistência aos outros discursos socialmente válidos na modernidade. Reaparece aqui, em primeiro lugar, o problema da capacidade da arte para resistir e opor-se à lógica da indústria cultural (que permeia a moral, a política, a ciência e a religião).

No capítulo anterior reconstruímos a lógica da indústria cultural a partir da explicação do processo de tecnificação da cultura e da interpretação crítica da "ideologia da transparência". Se trasladássemos esta problemática ao plano da experiência, para poder confrontá-la com os problemas da constituição da experiência estética, veríamos que tanto a tecnificação da cultura, quanto a ideologia da transparência, expressam-se nesse plano 
naquilo que Adorno denominou "compulsão identificadora" (Identitätszwang) do sujeito. ${ }^{118}$ Esta consiste na pressão que os sujeitos devem realizar habitualmente para eliminar as peculiaridades e para extrair aos objetos empíricos das situações particulares, de tal modo a torná-los equiparáveis e subsumíveis aos conceitos. Evidentemente, as tecnologias da comunicação da indústria cultural colaboram fantasticamente para este processo na modernidade tardia, razão pela qual Adorno e Horkheimer compararam em repetidas ocasiões seu procedimento com o do esquematismo kantiano. ${ }^{119}$ Ora, é precisamente contra este tipo de pressão no sentido da identidade que se expressa, para Adorno, a força da arte autônoma. Na Teoria Estética Adorno afirma: "A identidade estética tem que socorrer ao não-idêntico, que é oprimido na realidade pela compulsão identificadora" (das der Identitätszwang in der Realität unterdrückt, $\ddot{\mathrm{AT}}$ : 14).

Ao abordar a relação que se postula entre a força que gera a autonomia da experiência estética e a força que produz o princípio de identidade, esclarece-se a diferença entre Adorno e Habermas. Se este último considera que a função da arte na constituição da esfera pública consiste em ampliar e garantir formas livres e enriquecidas de identidade, Adorno, pelo contrário, propõe que a liberdade artística trabalha especialmente contra a identidade simbolicamente mediada. A partir daí, surgem duas ideias diferentes da relação entre a arte e a esfera pública. A primeira - defendida por Habermas - afirma que a autonomia da arte realiza-se na esfera pública mediante sua complementação com as outras esferas de valor (somando sua especificidade às formas de identidade que se reproduzem no “mundo da vida"). Por outro lado, a tese defendida por Adorno afirma que a autonomia da arte só se consegue por meio da negação da lógica interna das outras esferas simbólicas da

\footnotetext{
${ }^{118}$ Cfr., Adorno (ÄT): 14.

119 "An der Einheit der Produktion soll der Freizeitler sich ausrichten. Die Leistung, die der kantische Schematismus noch von den Subjekten erwartet hatte, nämlich die sinnliche Mannigfaltigkeit vorweg auf die fundamentalen Begriffe zu beziehen, wird dem Subjekt von der Industrie abgenommen. Sie betreibt den Schematismus als ersten Dienst am Kunden. In der Seele sollte ein geheimer Mechanismus wirken, der die unmittelbaren Daten bereits so präpariert, daß sie ins System der Reinen Vernunft hineinpassen. Das Geheimnis ist heute enträtselt. Ist auch die Planung des Mechanismus durch die, welche die Daten beistellen, die Kulturindustrie, dieser selber durch die Schwerkraft der trotz aller Rationalisierung irrationalen Gesellschaft aufgezwungen, so wird doch die verhängnisvolle Tendenz bei ihrem Durchgang durch die Agenturen des Geschäfts in dessen eigene gewitzigte Absichtlichkeit verwandelt." Adorno e Horkheimer (DA), 145-146.
} 
sociedade (por exemplo - e este não é um exemplo qualquer - por meio da negação do princípio de identidade que organiza a esfera de validez do conhecimento e da moral). Para indagar o conteúdo dessa distinção, resulta imprescindível, então, revisar esta delicada relação que existe entre a arte moderna, a autonomia da experiência estética e o princípio de identidade que pretende regular internamente todas as esferas de validez.

a) $\mathrm{O}$ problema do pensamento identificador na arte moderna

$\mathrm{Na}$ extensa série de revoltas contra as formas estabelecidas de conhecimento e compreensão que protagonizou o modernismo artístico, talvez seja dentro do formalismo russo onde esta questão tornou-se, pela primeira vez, um problema central da reflexão teórica. O poeta russo Victor Sklovski construiu um dos conceitos principais da sua teoria da arte, o conceito de "estranhamento" (ostranenie), como contraponto explícito daquilo a que poderíamos chamar: compreensão identificadora. Embora Adorno não o mencione explicitamente, no lugar privilegiado que ocupa a concepção do caráter enigmático (Rätselcharakter) da obra de arte na Teoria Estética, existem ressonâncias claras do conceito de ostranenie de Sklovski. Por outro lado, ambos compartilham também certa indefinição em relação ao sentido dos termos desta oposição na qual eles situam a arte. Tanto o conceito de ostranenie quanto a ideia do caráter enigmático da obra de arte pretendem mostrar um conflito entre a compreensão do sentido na experiência estética e a compreensão do sentido fora dela, sem que fique sempre claro qual é esse outro da experiência estética frente ao qual ela torna-se enigmática. De fato, o valiosíssimo (fundamentalmente para o modernismo literário) conceito de ostranenie de Sklovski contém diferentes formulações possíveis, as quais, embora não sejam necessariamente contraditórias, orientam-nos para uma ou outra posição teórica em relação aos fundamentos da autonomia estética. E o problema com estas formulações diversas é que todas elas indicam distintos termos da oposição e, portanto, diferentes alcances e conteúdos desta relação negativa. A seguir procuraremos reconstruir as três principais formulações possíveis do conceito de ostranenie, para associá-lo logo com a ideia do caráter enigmático da obra de arte e o problema da negatividade estética em Adorno. 
Em primeiro lugar, o conceito de estranhamento pode referir-se ao efeito que a arte produz, isto é, à possibilidade, atualizada no sujeito, de uma experiência do ato de conhecimento do objeto diferente da experiência do conhecimento conceitual. No centro desta outra experiência, a arte funcionaria motivando uma restituição ou intensificação das faculdades perceptivas que são constantemente minguadas ou adormecidas na percepção habitual da vida racionalizada. Quem se estranha, então, é o eu racional frente ao que lhe provê, no plano da experiência, a revitalização e a intensificação destas faculdades adormecidas. Sklovski apresenta esta formulação do efeito de estranhamento como o resultado da oposição entre: a- o conhecimento orientado no sentido do reconhecimento dos objetos da experiência (que aqui chamamos de compreensão identificadora); e b- o conhecimento que depende de formas de percepção imediata, que se constituem numa relação de afinidade com a singularidade dos objetos da experiência (conhecimento prévio a qualquer processo de identificação). "Para dar sensação de vida - proclama Sklovski -, para sentir os objetos, para perceber que a pedra é pedra, existe isso que se chama arte. A finalidade da arte é dar uma sensação do objeto como visão e não como reconhecimento; os procedimentos da arte são aqueles da singularização dos objetos."120 Neste sentido, o conceito de estranhamento delimita negativamente essas duas formas de conhecimento nãosubsumíveis uma à outra, que são postas por intermédio da arte como reciprocamente opostas (o reconhecimento como negação da percepção imediata, mas também esta última como negação do reconhecimento).

Derivada desta diferença em relação ao conhecimento conceitual surge a segunda interpretação. Por tratar-se a arte de um conhecimento, mas de um conhecimento que não depende de conceitos, a ideia do estranhamento como efeito produzido por ela pode indicar a particularidade do objeto que é causa da experiência estética. Se a compreensão identificadora restringe-se ao procedimento que pretende realizar o reconhecimento do finito e condicionado na experiência, o estranhamento que a arte produz bem pode ter sua origem no fato de que por meio dela o homem se relaciona com o infinito e o incondicionado. Deste modo, o que é estranho é o autêntico objeto-causa da experiência artística, em relação a todos os objetos da experiência possível para a mediação categorial.

120 Sklovski, V., “El arte como artificio”, in Todorov, T., Teoría de la literatura, Madrid, Siglo XXI, 1990, p. 60. 
A arte como meio e espaço de abertura do incondicionado, do objeto da metafísica por oposição ao objeto da ciência, retoma a formulação kantiana que prometia, para a experiência estética, a possibilidade de acessar sensivelmente à coisa em si.

Finalmente, o conceito de estranhamento pode referir-se a uma diferença na temporalidade da compreensão, com relativa independência de seu objeto ou das faculdades que intervêm. $O$ fundamental nesta acepção é a relação entre o tempo e o ato da compreensão. "O procedimento da arte - diz Sklovski - consiste em obscurecer a forma, em aumentar a dificuldade e a duração da percepção. $\mathrm{O}$ ato de percepção é na arte um fim em si e deve ser prolongado. A arte é um meio de experimentar o devir do objeto: o que já está 'realizado' não interessa para a arte."121 O efeito de estranhamento implica agora na suspensão e na prolongação no tempo daquilo que toda compreensão identificadora realiza, por assim dizer, automaticamente. A negatividade da arte já não se daria como supressão de uma faculdade por causa da revitalização de outra, ou como superação de um objeto graças à aparição de outro superior, mas sim como interrupção e prolongação temporal das formas "espontâneas" e automatizadas de compreender, graças ao assombro que inscreve nelas uma duração indefinida.

Quando Adorno pensa o caráter enigmático da obra de arte e, junto com ele, a negatividade estética, fá-lo a partir de uma série de oposições que relembram esta ideia de estranhamento estético em suas três formulações possíveis. À compreensão identificadora, que domina na vida prática, Adorno opõe-lhe o caráter enigmático e expressivo da obra de arte, nos seguintes termos:

As obras falam como as fadas nas fábulas: "queres o incondicionado; será teu, mas incognoscível." A verdade do conhecimento discursivo existe sem véus (Unverhüllt), mas, por isso mesmo, ele não a possui; o conhecimento que a arte é a possui, mas como incomensurável em relação ao conhecimento discursivo. [...] Finalmente, subsiste no caráter enigmático, por meio do qual a arte opõe-se à existência inquestionável dos objetos da ação, o enigma que eles mesmos contêm. A arte transforma-se em enigma porque ela aparece como tendo resolvido aquilo que na existência é um enigma, ao passo que no meramente existente o enigma está esquecido devido a seu próprio endurecimento opressivo. Quanto mais compactamente cobriam os homens, com a rede categorial, aquilo que é outro em relação ao espírito subjetivo, tanto mais profundamente desacostumam-se do

121 Ibid. 
assombro frente à alteridade; com esta familiaridade senganam-se a respeito do estranho. A arte procura reparar (wiedergutzumachen) isso debilmente. (ÄT: 191)

Resulta evidente nesta passagem que o que Adorno opõe ao caráter enigmático da obra de arte é o pensamento conceitual, que ele coloca em uma situação de equivalência estreita à "compreensão identificadora". A tarefa "reparadora" da experiência estética consistiria em superar a unilateralidade e a violência que a mediação conceitual estabelece sobre a alteridade. Entretanto, esta oposição não deixa de ser imprecisa para determinar a singularidade da negação estética, já que também o pensamento religioso e distintas formas radicalizadas do empirismo opõem-se ao pensamento conceitual, sem que possam ser confundidas em si mesmas com a peculiaridade do estético. Essa ambiguidade colabora fatidicamente na incompreensão do pensamento crítico de Adorno, pelo qual deve ser esclarecida no momento de utilizar sua teoria na análise da esfera cultural das sociedades contemporâneas. Caso contrário, persistindo essa ambiguidade, a crítica habermasiana, que vincula seu pensamento a restos neo-românticos incompatíveis com a complexidade do presente, tornar-se-ia completamente acertada.

Pois bem, apesar de que Adorno nunca termina de rejeitar a legitimidade da pergunta pelo incondicionado na arte, assim como a possibilidade de um deslocamento em direção a formas de conhecimento que transcendam o conhecimento conceitual dos objetos da experiência, não se poderia afirmar que estas formulações do caráter enigmático da obra de arte sejam a única resposta possível, pois a própria Teoria Estética contém elementos para rever esta questão. Christoph Menke tem demonstrado como aquilo que habilita uma má interpretação deste problema na teoria de Adorno consiste na equiparação apressada que ele sugere entre a "compreensão identificadora" e o trabalho do "pensamento conceitual". Para Menke, essa equivalência implica uma determinação insuficiente do problema do pensamento identificador na arte, já que a oposição com o "pensamento conceitual" não permite definir adequadamente aquilo sobre o qual opera negativamente a obra de arte. Como resultado dessa desafortunada equiparação, desconhece-se a essência radicalmente negativa do problema, e se abre a possibilidade de interpretar na teoria de Adorno uma superação positiva do conhecimento conceitual por meio da arte, seja por intermédio de uma relação afirmativa com o incondicionado ou da afirmação de faculdades não-racionais existentes no sujeito. 
No entanto, não é difícil encontrar os elementos teóricos para reformular esta questão no próprio Adorno. Por um lado, a menção que ele faz à presença do incondicionado na obra de arte ("o conhecimento que a arte é o possui") como causa da negação estética do pensamento identificador aparece relativizada, logo, na distinção entre o caráter enigmático da arte e os mistérios: "o enigmático das obras de arte consiste em ser algo fraturado (Abgebrochensein). Se a transcendência estivesse presente nelas, haveria

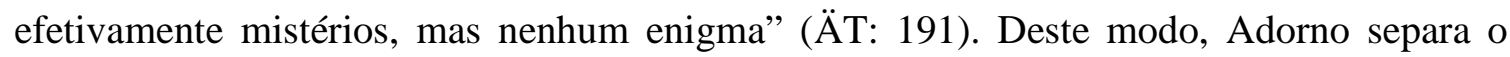
enigmático da obra de arte do cânone classicista, que transforma a materialidade sensível da obra em um receptáculo perfeito para a manifestação simbólica do suprassensível.

A lógica que transforma a obra de arte em um objeto cifrado, impenetrável para a compreensão identificadora ordinária, não provém, pois, da afirmação de uma instância transcendente, mas sim da imersão na existência, fazendo aparecerem "os enigmas que ela mesma contém". Adorno se opõe, deste modo, ao cânone classicista e romântico que quer ver na arte a manifestação sensível de um sentido transcendente positivo, que foge uma e outra vez da finitude da experiência humana. O caráter enigmático da obra de arte não implica um momento de fusão significante, no qual se soldariam entre si o sentido suprassensível com o corpo sensível da significação. A esta fusão, frente à qual o homem emudece (na contemplação desse objeto que está fora de seu alcance), Adorno reserva-lhe o nome de mistério e a exclui da experiência estética (autônoma).

Por outro lado, tampouco a acepção do enigmático como motivado pela revitalização de faculdades perceptivas não-racionais pode prosperar. Adorno foi sempre muito crítico da desagregação analítica do sentido obra de arte, que o pretende reconduzir a um conjunto de estímulos-respostas sensoriais. Para Adorno, não entende o conteúdo objetivo de uma obra de arte (e da experiência estética) quem a interpreta a partir dos efeitos dos elementos sensíveis isolados que ela mobiliza. Ao supor legítima esta redução, "desaparece a diferença da obra de arte em relação às meras qualidades sensíveis; a obra de arte formaria assim parte da empiria, seria a battery of tests, e o meio adequado para dar conta da arte seria o program analyzer ou a pesquisa acerca das meias reações dos grupos

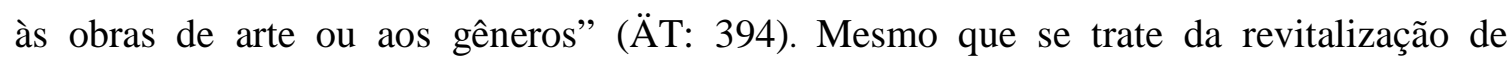
faculdades adormecidas, nunca é a partir delas que se pode conformar a essência negativa do conteúdo da obra de arte. Supor esta determinação seria supor que a constituição 
objetiva da obra de arte tem como finalidade adaptar-se ao sujeito, convergindo assim "com os critérios da indústria cultural, que organiza seus produtos como sistemas de estímulos" (華: 395).

Existe uma última alternativa interpretativa, referida ao fundamento do enigmático da arte, que devemos analisar e criticar. Esta interpretação destaca (unilateralmente) a especificidade do estatuto cognitivo da criação artística, ou seja, destaca como elemento que singulariza a arte a sua condição de criação ficcional. A diferença em relação ao resto dos objetos empíricos surgiria, neste caso, da possibilidade de transcender o existente, o estado atual das coisas, em uma realidade imaginária criada pela especificidade da produção artística. Aquilo que a aparência estética revela seria, deste modo, uma configuração da realidade que não pode existir no estado atual do mundo sob a rígida legalidade natural e social, tal qual a reconhece o procedimento objetivador da ciência positiva. Se o pensamento identificador pretende alcançar a determinação objetiva do estado de coisas do mundo, pode supor-se que a arte, como negação determinada desse modo de proceder, apoia-se nesse movimento de transcendência subjetiva da realidade que a tradição denominou fantasia. Assim estabelecida a oposição, aquilo que se levantaria contra o pensamento identificador seria a capacidade do sujeito para criar, no plano da representação, um mundo no qual não se regem como restrições as leis que regulam o mundo social e o mundo natural, tal como o conhecemos.

A fantasia como fundamento da arte depende da ideia de creatio ex-nihilo, e por ela responde, na teoria moderna da arte, o conceito vulgar de invenção absoluta. Existe uma extensa fundamentação da autonomia da arte moderna que depende deste conceito de fantasia, cujo produto, a ficção artística, aparece como sua autêntica objetividade. Poderse-iam oferecer múltiplos exemplos da presença deste conceito de fantasia na fundamentação da arte moderna. A antítese com o mundo social divulgada pelo princípio do art pour l'art não é alheia a esta consideração e se torna solidária à mesma crítica. Adorno formulou-a a partir do exame do tipo de transcendência que ambas propõem. De fato, a negatividade que apresenta a fantasia artística cai facilmente em ideologia pelas mesmas razões que a teoria da arte pela arte fracassa em sua ideia, ao pretender uma autonomia e um prazer estético puros. Ambas neutralizam a negatividade da arte, mas não por sua oposição radical ao mundo existente, "mas sim pela abstração e pela facilidade 
dessa antítese" (ÄT: 351). A transcendência do princípio de realidade que faz possível o conceito de fantasia recai em seu contrário quando, como se comprova em muitos autores do modernismo, pretende fazer do princípio construtivo da arte algo absoluto. O próprio caráter de criação a partir do nada implica um abandono da existência que faz da fantasia artística um mero complemento do mundo existente e não uma forma radical de negatividade. Adorno ressaltou acertadamente de que modo a eliminação de qualquer conteúdo que seja alheio à fantasia artística, quer dizer, que quebre sua condição de ser uma invenção absoluta, é, precisamente, a causa de sua recaída em um conceito dogmático do belo que anula a negatividade estética. A fórmula desta situação paradoxal diz assim:

A ideia de beleza, que erige o princípio da art pour l'art em sua evolução pós-baudelairiana, - se bem não seria formal-classicista -, amputa todo conteúdo que não se submeta à lei formal da arte (inclusive em termos antiartísticos), dobrando-se assim ante um cânone de beleza dogmático: com este espírito George critica, em uma carta a Hofmannsthal, o fato de que em uma nota de A morte de Tiziano deixasse que fosse a peste a causa do desenlace fatal do pintor. O conceito de beleza da art pour l'art torna-se, ao mesmo tempo, vazio e muito determinado pela matéria. [...] A beleza, incapaz de determinar-se a si mesma, dado que só pode determinar-se em seu outro, fica enredada, como se fosse uma raiz aérea, no destino da invenção ornamental. Esta ideia do belo é limitada porque está em antítese imediata com a sociedade à qual rechaça como feia. (ÄT: 352)

A negatividade da fantasia deixa intata a divisão do trabalho que atribui à ciência a mediação objetiva da realidade e à arte sua transcendência abstrata e subjetiva. Esta passagem crítica da teoria de Adorno é de vital importância porque permite rejeitar, definitivamente, a frequente acusação de esteticismo com que se ataca sua ideia de autonomia da arte e a dimensão utópica da sua filosofia social. Devemos chamar de esteticista, pelo contrário, exclusivamente essa autonomia que nega abstratamente o mundo que diz rechaçar e se assenta na lógica da totalidade social como uma esfera complacente e complementar, como pretendia a teoria habermasiana. O conceito de fantasia artística delimita perfeitamente o horizonte deste tipo de autonomia. Sua oposição à realidade objetiva e às faculdades identificadoras do sujeito, ao excluir todo conteúdo que não se submeta a seu princípio construtivo, constitui uma fuga superficial do existente que se resolve na mera postulação de algo não-existente como existente. Uma análise estética dos resultados deste procedimento de enriquecimento da experiência tem que mostrar como o 
princípio criador que anima o conceito de fantasia artística parte e culmina na mesma existência que a fantasia queria ter superado. Ao pretender determinar a arte a partir de um poder configurador superior, esta construção de objetos que não existem não consegue nada que, em seus elementos e conexões, não seja redutível a algo existente. Efetivamente, os momentos de criação livre são intrínsecos à produção artística. Mas o conceito de fantasia artística pretende fundar nesses momentos, que têm que ser considerados como mediados imanentemente pelo existente, a autonomia de uma representação que não passa de ser a “projeção inútil do existente". ${ }^{122} \mathrm{O}$ caráter abstrato desta negação da realidade está determinado subjetivamente por sua condição de fuga frente à realidade, e objetivamente pela eliminação absoluta do conteúdo das formas não-estéticas de compreensão. A debilidade desta negação faz o procedimento do estranhamento artístico ficar confinado às possibilidades da distorção ou do desvio do curso normal das representações, construindo estas representações fantasiosas uma transfiguração que não interrompe, nem afeta em nada, as formas de compreensão ordinárias, mas as deixa de lado ou as utiliza para seus próprios fins. Paradoxalmente, a autonomia assim conseguida, que se pretende pura e absoluta, torna-se complacente com o estado do mundo que queria rejeitar.

A posição de Adorno parece sugerir que todas as anteriores interpretações do caráter enigmático da arte e da autonomia da experiência estética são unilaterais. Por isso, só mediante sua crítica recíproca poderemos obter um conceito adequado aos dilemas da arte nas sociedades contemporâneas. Nesse sentido, as posições que comentamos acima podem ser pensadas como os extremos de uma relação dialética. Agora, o outro da compreensão estética já não pode ser o pensamento conceitual, que é aquilo ao qual se opõem unilateralmente a fantasia, o objeto da metafísica e a percepção imediata. Esta outra configuração da relação negativa que existe entre o caráter enigmático da obra de arte e o pensamento identificador permite expor a estrutura radicalmente negativa e antiteleológica da negatividade estética. Para avançar nesta linha de indagação, utilizaremos a correção que Menke propôs desta questão. Esta baseia-se retomando o último sentido do conceito de ostranenie de Sklovski que analisamos anteriormente, na distinção entre atos de compreensão automáticos e atos de compreensão não-automáticos:

${ }^{122}$ Cfr., Adorno (ÄT): 258-260. 
A noção de automatismo permite reformular a estrutura fundamental da compreensão nãoestética sem reduzi-la à univocidade definível do conceito. Pois o automatismo determina a oposição entre as duas formas de compreensão, a estética e a não-estética, não em função da estrutura de seu objeto respectivo, mas em função da modalidade do cumprimento do ato mesmo da compreensão. São automáticos os atos de compreensão que terminam em uma identificação do objeto que é compreendido por meio de convenções. Pelo contrário, os atos não-automáticos são os que acabam em um processo de identificação sem a ajuda de convenções. Embora ambos modos de compreensão façam intervir na identificação, só a identificação automática é identificação no sentido de Adorno. Na compreensão automática a compreensão é um resultado; na compreensão estética é um processo. (Menke, 1997: 53)

Com esta aclaração dos termos da oposição adorniana, pode pensar-se a negatividade estética como o movimento que faz possível a autonomia da arte, mas não por possuir um objeto transcendente, por estimular um uso extraordinário das faculdades cognitivas ou por ser capaz de criar ficcionalmente outro mundo. Sua força de negação residiria, nesta outra interpretação, na capacidade para interromper e suspender imanentemente as formas da compreensão identificadora que prevalecem na linguagem fossilizada pela tecnificação da cultura. A tese de Adorno postula o núcleo temporal da obra de arte como o responsável por essa singular capacidade de interferir no normal funcionamento da compreensão identificadora, sendo esta sua diferença específica em relação às outras formas de oposição possíveis. Ao inserir esta consideração relativa à dimensão temporal da obra, Adorno realiza uma fundamentação polêmica da autonomia estética, que se opõe à interpretação sociológico-institucionalista. Para Adorno, a autonomia da arte não é um fato, uma conquista histórica depositada no acervo cultural das sociedades modernas, mas trata-se de um processo sempre inacabado, um devir autônomo, nunca conseguido de uma vez por todas. Aqui se torna decisiva a exposição adequada da oposição ao pensamento identificador, esse pano de fundo sobre o que se recorta a necessidade da diferença da arte.

Frente às três formas da negação do "pensamento identificador" que examinamos, isto é, o mistério, o caos de sensações e a fantasia, distingue-se a negatividade estética que procura fundamentar Adorno graças à categoria do caráter enigmático da obra de arte pela sua definição a partir do caráter processual da compreensão que suscita. ${ }^{123}$ Menke

${ }^{123}$ Cfr., Adorno (ÄT): 183 e ss. 
observou com muita precisão esta questão. Em sua leitura da teoria da negatividade estética de Adorno, essa negatividade não se constitui a partir de um uso excepcional das faculdades perceptivas, nem do conhecimento de um objeto extraordinário, nem do uso não-habitual dos signos que encerram a representação objetiva do mundo, mas a partir da “desautomatização dos procedimentos ordinários de identificação" (Menke, 1997: 55). Deste modo, o outro do pensamento identificador já não é algo existente em si (o suprassensível, as sensações não-habituais, as fantasias), mas a negação da existência, o outro da existência: o devir.

O caráter processual da obra de arte pode funcionar adequadamente como categoria da negatividade estética (radicalizada), sem apelar à capacidade subjetiva de anular o conteúdo da compreensão identificadora, mas por sua própria condição negativa, por não ser nada fora dessa negatividade que destrói de dentro o pensamento identificador. Ao suscitar no ato automatizado de compreensão da vida ordinária um processo, a intervenção da arte não erige uma segunda realidade rebelde, oposta à primeira realidade do mundo ordinário, mas transforma a compreensão da realidade de algo existente em um devir. A alteridade da arte não se dirige, neste caso, no sentido da afirmação de outro mundo ou da compreensão de outras coisas diferentes das habituais, mas atua negativamente dentro do mecanismo que estabelece a identificação e o reconhecimento do mundo nas diferentes esferas da vida social. Essa negação não nos permite "compreender outra coisa, mas compreender de outro modo" (Menke, 1997: 55). Tal como o estabelecia a ideia de Sklovski, a arte não nos oferece a experiência do estranho em presença do desconhecido, mas a capacidade para sentir estranhamento frente ao que conhecemos muito bem, como diria Adorno, tão bem que apagamos nele "a experiência da alteridade". A correção que a obra de arte produz desencadeia uma série de dificuldades na "espontaneidade" do ato da compreensão, inscrevendo-o em um processo de duração indefinida. Deste modo, libera a compreensão da exigência de consumar-se em um resultado. Só neste sentido pode dizer-se que a negatividade estética é aquela que se opõe a e subverte o pensamento identificador.

A diferença entre a situação negativa e paradoxal na qual Adorno situa a arte autônoma e a situação de complementaridade positiva postulada por Habermas produz múltiplas consequiências teóricas, que resultam relevantes para o interesse central de nosso 
trabalho. A idéia de "publicidade" (Öffentlichkeit) que utiliza o conceito habermasiano de cultura, marcada pelas idéias de "abertura" e "transparência" do espaço no qual os sujeitos realizam suas trocas simbólicas (Habermas, 1990: 58 y ss.), entra imediatamente em conflito com a interpretação adorniana da arte na modernidade cultural. Habermas defende a tese da comunicabilidade dos conteúdos das diferentes esferas de pretensões de valor nas quais se separa a racionalidade moderna e inclui nessa tese (neste aspecto, "indiferenciada") a autonomia estética. O núcleo da fundamentação habermasiana consiste em projetar a eficácia explicativa e crítica de seu conceito de comunicação intersubjetiva nas relações globais entre as diversas esferas culturais. Assim como, por meio da comunicação, os sujeitos se abrem para a alteridade, entram em contato com a liberdade individual do outro e geram as condições para um acordo racionalmente motivado, do mesmo modo, na comunicação entre as esferas culturais no "mundo da vida" moderno, elas (ciência, moral, estética) se abrem para a diferença, respeitam a liberdade da legalidade e dos procedimentos das outras e produzem plexos normativos flexíveis e continuamente melhoráveis. A abertura e a transparência do espaço das trocas simbólicas são, para Habermas, as condições que garantem este duplo movimento das "originais" pretensões de validez da modernidade cultural: a) a participação livre e igualitária dos sujeitos na formação comunicativa da própria identidade; b) a comunicação entre as diversas esferas de valor e seus respectivos conteúdos particulares (critérios de verdade, valores morais e valores estéticos) na formação de uma mesma esfera pública.

Quando se analisa o paradigma da comunicação da perspectiva da autonomia da arte moderna, resulta evidente que aquilo que funciona relativamente bem para a moral e para a ciência, não funciona da mesma forma para a arte. As condições de transparência e abertura do espaço simbólico garantem, em principio, a formação comunicativa dos acordos em relação à verdade e à justiça, mas decididamente não garantem o efeito específico da arte autônoma: o estranhamento em relação à compreensão identificadora. Isso se deve a que tanto na ciência quanto na moral a identidade é um pressuposto (critérios e valores aproblemáticos que regulam a interação) e um resultado (discurso do saber, discurso da justiça) que deve ser alcançado necessariamente no processo comunicativo. Para realizar essa identidade entre as diferentes partes resultam imprescindíveis, então, a abertura e a transparência do espaço simbólico. Porém, elas nem são um requisito, nem facilitam a 
peculiaridade da arte autônoma. Pelo contrário, a transparência e a abertura do espaço simbólico são as condições contra as quais se exerce a força social do modernismo artístico, impossibilitando a formação de processos de identificação semelhantes aos da moral e a ciência. Aqui é onde o paradigma habermasiano falha sistematicamente. Ele não consegue subsumir a particularidade da experiência estética num único conceito de "publicidade" das práticas simbólicas.

Ora bem, esta limitação do paradigma da ação comunicativa para compreender a arte moderna reflete, por sua vez, uma subestimação das pretensões da arte na modernidade e uma superestimação da capacidade das pretensões normativas da ciência e da moral para formar, em termos não-violentos, um espaço comum para todas as práticas simbólicas. Somente quando se abandona a superestimação da moral e da ciência é possível prestar atenção às potencialidades da arte para a teoria critica. Esta passagem, evidentemente, é aquela que Habermas nunca tentou efetuar no percurso de sua obra. Mas é também aquela que ele não compreende na obra de Adorno, fundamentalmente quando o acusa de utilizar a arte como modelo de uma "racionalidade anterior à racionalidade", que promove um "recentramento" da cultura e do sujeito ao interior de uma unidade que dissolve todas as diferenças da modernidade cultural. ${ }^{124}$ Acreditamos ter demonstrado por que este juízo é falso. O interesse de Adorno não consiste em achar na arte um substituto da identidade racional entre o idêntico e o não-idêntico. Pelo contrário, o interesse dele concentra-se no estranhamento em relação à identidade, na modalidade do conflito que existe entre a arte autônoma e os processos de identificação comunicativamente constituídos (nos quais se baseiam a ciência e a moral, mas também as mitologias mágicas, religiosas ou metafísicas), e não numa forma superior ou não-racional de identidade.

Com efeito, o estranhamento estético depende de um tipo radical de "descentramento" do sujeito e das práticas simbólicas, diferentemente do que propõe a análise da Teoria Estética de Adorno que fez Habermas para justificar a necessidade do cambio de paradigma. Talvez devamos achar aqui a discrepância fundamental, implícita em toda esta polemica em torno da arte: a diferença entre dois modelos de descentramento do sujeito e das práticas simbólicas, descentramento reconhecido por ambos como condição de

\footnotetext{
${ }^{124}$ Cfr. supra pp. 51 e ss.
} 
possibilidade de uma racionalidade não-violenta. De um lado, temos o modelo do descentramento habermasiano, baseado na comunicação intersubjetiva. Do outro, o modelo do descentramento que defende Adorno, baseado no estranhamento da experiência estética. Nesta confrontação, a linha de pesquisa adorniana destaca duas grandes desvantagens no paradigma comunicativo, que o descentramento estético - como diz Adorno - procura reparar (wiedergutzumachen) debilmente:

1. Em primeiro lugar, a categoria de descentramento que põe em prática a comunicação intersubjetiva resulta completamente impotente frente aos dispositivos que tecnificam a cultura. Como temos enfatizado, as sanções que disciplinam as interações e forçam as identificações simbólicas se realizam através do descentramento comunicativo do sujeito, e não apesar dele.

2. Em segundo lugar, o descentramento do paradigma comunicativo se adapta com facilidade às pretensões da moral e da ciência, mas ao preço de negligenciar a peculiaridade da autonomia estética. Conforma um modelo facilmente universalizável, mas para tornar-se universal tem que subsumir ou excluir uma parte importante da modernidade cultural.

A recuperação filosófica da arte que realiza Adorno supõe uma superação destas duas limitações, dado que o descentramento da arte autônoma suspende criticamente a funcionalização comunicativa da linguagem, sem suprimir as outras esferas da racionalidade moderna (pelo contrário, as conserva no interior de uma negação que a arte é estruturalmente incapaz de "resolver"). Para estudar o alcance desta tese analisaremos, no ponto seguinte, a relação que Adorno estabelece entre a arte autônoma e a linguagem comunicativa. 
b) Construção mimética e dissolução expressiva.

Temos proposto na seção anterior que uma das teses fundamentais da estética de Adorno consiste em contrapor a lógica do sentido da obra de arte autônoma com os usos comunicativos da linguagem. Desvendamos uma primeira interpretação dessa contraposição, ao analisar a relação que existe entre o caráter processual do estranhamento estético e a compreensão identificadora, tentando desmarcar a idéia de negatividade estética de Adorno da concepção metafísica, empirista e idealista. A análise do caráter processual da compreensão estética requer, agora, explicitar seu mecanismo interno e seus efeitos sobre as outras esferas culturais.

Ao afirmar que a arte autônoma tende a desautomatizar o ato de compreensão, suscitando um processo que não se resolve num resultado, tentamos mostrar de que maneira a unidade de sentido na arte é sempre algo internamente instável. Ao sintetizar momentos incompatíveis, em "fricção", a obra de arte vê-se obrigada a alcançar sua identidade mediante um processo, dado que "na arte a unidade é um momento e não a fórmula mágica do todo"125. Neste sentido, sua processualidade não tem que ser concebida enquanto mera prolongação da duração do ato positivo da compreensão, mas sim como uma interrupção permanente da aparição do sentido. A processualidade do caráter enigmático da obra de arte supõe o esforço sempre renovado de efetuar uma compreensão com vistas à decifração do sentido do percebido, que fracassa objetivamente, pelas tensões internas que a obra reúne.

Para Adorno, o impulso mimético que mobiliza socialmente a arte sofre, na modernidade artística radical, uma diferenciação interna, que logo dá sua forma ao campo de forças enfrentadas que constituem as obras autônomas. A mimesis se transforma, por um lado, no momento construtivo da aparência de autonomia absoluta das obras e, pelo outro, no momento expressivo, que as vincula com o exterior. ${ }^{126} \mathrm{O}$ estranhamento e a processualidade da compreensão provêm da dialética entre estes dois momentos, que constituem assim o singular núcleo temporal da obra de arte.

\footnotetext{
${ }^{125}$ Cfr., Adorno (ÄT): 262.

${ }^{126}$ Cfr., Adorno (ÄT): 154 e ss.
} 


\section{b1.- O momento mimético-construtivo}

Enquanto componente da obra de arte, o momento construtivo é o que produz sua separação enfática do mundo empírico mediante a seleção e a articulação dos elementos que farão parte da unidade dessa obra de arte. O princípio construtivo é aquele que articula exitosamente as partes entre si, fazendo com que desapareçam enquanto elementos isolados, e que apareçam como a representação de "algo mais". Adorno denomina esse "algo mais" que produz a mimesis-construtiva como o "espírito" da obra de arte, que depende inteiramente desta instância de totalização e unidade. O espírito da obra de arte surge precisamente da síntese daquilo que, na faticidade, existe como pura multiplicidade e diversidade, seguindo uma determinada relação que é capaz de fixar uma idéia. No plano material, o momento construtivo é aquele que exige que nenhum detalhe do que aparece fique isolado e sem relação com tudo o que o rodeia, constituindo assim a unidade da obra a partir da articulação e a síntese de aspectos diversos de um material heterogêneo. Ao produzir a continuidade estrutural de uma parte na outra, o princípio construtivo habilita um jogo de remissões e antecipações recíprocas, que acaba proclamando o caráter significativo das obras de arte. As partes tornam-se, tendencialmente, membros com sentido de uma unidade orgânica original, na qual os materiais reunidos adquirem um elo interno que os separa, de uma vez e para sempre, da contingência natural da faticidade.

Enquanto seleciona materiais diversos e os articula numa unidade de sentido, o momento construtivo se assemelha à seleção e articulação dos elementos significantes dos signos lingüísticos. A diferença entre ambos radica, entretanto, no fato de que a articulação do material no campo da arte não possui nenhum modelo a priori que seja análogo ao dos signos convencionais. Ao ser contrastado com esta situação dos signos convencionais, o momento construtivo da obra de arte se deixa pensar como o esforço por determinar, sem contar com o auxílio decisivo de um código preexistente, o valor significante de um dado material com vistas a uma significação singular. Com efeito, no signo convencional, a passagem da condição de puro material sonoro ou visual para a condição de material significante, se define pela possibilidade de comparar o traço (visual ou sonoro) efetivamente construído por um falante com um modelo formal do significante, que permite a prova de sua identidade. Pelo contrario, na obra de arte, a formação dos significantes não 
conta com esse modelo a priori para poder determinar quais os traços devem adquirir um valor significante e quais não. Sem essa diferencia, sua diferença tornar-se-ia impensável.

Deste modo, a unidade à que tende o esforço mimético construtivo é sempre uma unidade "original", dado que sua articulação não reconhece a limitação de nenhuma unidade convencional. Isto não impede, porém, que essa unidade original que é o objeto estético possa reproduzir em sua articulação interna mediações formais parecidas àquelas dos signos extra-estéticos. De fato, o princípio construtivo repete formalmente, no interior da obra, o processo de produção de significantes (ainda que o faça distorcendo-os e modificando-os por completo), que a organização social do sentido faz automaticamente por meio dos códigos convencionais.

A hermenêutica encarregou-se de ressaltar esse parentesco de família entre os signos "estranhos" da arte e os signos ordinários da comunicação humana, tentando evitar ao mesmo tempo que tal familiaridade implique necessariamente uma perda drástica de autonomia da arte. A tese hermenêutica situa, com efeito, os signos artísticos por fora do horizonte de sentido atualizado socialmente num momento dado, mas não aceita que essa distância seja enxergada como se de algo inaproximável se tratasse. O objetivo da hermenêutica filosófica consiste em demonstrar a possibilidade de uma progressiva integração no horizonte de sentido constituído dos "signos estranhos" da arte, através de sucessivas tentativas de compreensão. Um objeto estético pode transformar-se, neste sentido, em algo tão estranho quanto um signo da história remota, cujo contexto de inteligibilidade foi eliminado irrevogavelmente pelo tempo, sem que por isso sua estrutura interna nos resulte absolutamente incompreensível. Ambos são efetivamente estranhos para nós, porque carecemos do horizonte completo que lhes dá sentido e que permite compreendê-los. Entretanto, sabemos que podem tornar-se, em distintos graus, compreensíveis enquanto corpos estranhos, se os incorporarmos respeitando sua diferença ao interior de um determinado horizonte atual de sentido. O que permite explicar esta integração entre o estranho e o conhecido, entre a alteridade e a identidade, é a familiaridade secreta que existe entre aquilo que temos denominado o momento construtivo da obra de arte e a formação dos elementos significantes da linguagem. Com efeito, as teses hermenêuticas impedem de falar de algo que possa ter sentido por fora da perspectiva que institui um determinado horizonte interpretativo (que é, por definição, um horizonte 
valorativo), que é aquele que prescreve a diferença entre o significante e o insignificante. Ora bem, se esta tese não for reificada, ela mesma estabelece as condições para a incorporação de um traço estranho, de um signo relativamente diferente aos que formam parte do universo de sentido efetivamente instituído. Ao respeito diz Gadamer:

Tínhamos partido da idéia de que uma situação hermenêutica está determinada por preconceitos que levamos conosco. Nesse sentido, formam o horizonte de um presente, pois representam o que o olhar não pode ultrapassar. Convém, entretanto, evitar o engano que consistiria em acreditar que o horizonte do presente está determinado e delimitado por um conjunto imutável de opiniões e valorações. [...] Em realidade, o horizonte do presente está em formação contínua, na medida em que precisamos pôr a prova constantemente nossos preconceitos. [...] Não há horizonte do presente que possa existir por si mesmo como não há, tampouco, horizonte histórico que se possa conquistar. A compreensão consiste, melhor, no processo de fusão desses horizontes isolados. ${ }^{127}$

Os signos da arte, como já o percebeu Gadamer na sua apresentação da hermenêutica em Verdade e Método ${ }^{128}$, apresentam um dos melhores exemplos de uma alteridade "singular" que pode, entretanto, integrar-se e "fundir-se" num horizonte de sentido, do qual não forma parte atualmente. A incompreensibilidade da obra de arte revela, precisamente, a possibilidade deste desdobramento interno de toda estrutura simbólica sócio-histórica, que permite acolher o estranho instituindo uma relação temporal (ao exigir aproximações sucessivas de parte de quem compreende), sem necessidade de suprimi-lo mediante a projeção, a partir do presente, das chaves de seu sentido. Neste caso, o estranho da originalidade da articulação e a unidade dos signos artísticos não implica a supressão da relação com o horizonte de sentido existente, mas se inscreve nele ao modo de uma interrogação, como uma petição de transformação. Finalmente, "o que o signo estranho que resiste à compreensão tem para dizer, isso que só ele pode dizer, só diz a nós."129

Ora bem, o segredo do fato de que o objeto estético possa ser compreendido como estranho, radica em que suas articulações internas transgridem só parcial e momentaneamente os códigos de simbolização disponíveis, e que tem a capacidade para interpelar esses códigos eficazmente a partir de sua distância. Temos que pensar em esta

\footnotetext{
${ }^{127}$ Gadamer, H., Wahrheit und Methode, Mohr, Tubinga, 1975, pág. 289.

${ }^{128}$ Ver, Gadamer, H., "Freilegung der Wahrheitsfrage an der Erfahrung der Kunst", in: Wahrheit und Methode, Mohr, Tubinga, 1975.

${ }^{129}$ Menke, Ch., La Soberanía del arte, la experiencia estética en Adorno y Derrida, Madrid, Visor, 1997, pág. 118.
} 
chave aquilo que Adorno denomina momento mimético-construtivo da obra de arte. Ele é o que faz possível a intervenção da arte no horizonte de sentido constituído. Deste ponto de vista, a dificuldade do signo estético estabelece que ele não pode ser imediatamente compreendido, mas que, mediante sua própria construção, solicita sê-lo a partir de um contexto renovado que compreenda o que agora não pode compreender. Adorno explicita esta situação recorrendo a um poema de Rilke:

O verso de Rilke - «Pois lá não há lugar / que não te mire» -, que Benjamin tanto apreciava, codificou de um modo dificilmente superado a linguagem não significativa das obras de arte: a expressão é o olhar das obras de arte. Em comparação com a linguagem significativa, a linguagem das obras de arte é mais antiga, mas não foi cumprida (Uneingelöstes): como se as obras de arte, ao modelarem-se pela sua estrutura sobre o sujeito, repetissem o modo do seu surgimento e da sua libertação. Têm expressão, não quando comunicam o sujeito, mas ao estremecerem com a pré-história da subjetividade. (苂: 172).

Nesta passagem da Teoria Estética, Adorno distingue e, ao mesmo tempo, vincula o caráter lingüístico da obra de arte e a linguagem como meio de significação. Ao se tentar fundir ambos os horizontes, o que aparece é uma negação ("a linguagem não significativa das obras de arte") e uma interrogação (o olhar das obras de arte sobre quem as contempla: "pois aí não há nenhum lugar que não te olhe"). A negação se produz porque ambas as construções significantes circunscrevem conteúdos diferentes, que entram em conflito. A interrogação, por sua parte, é o modo através do qual a arte exerce essa negação.

Adorno interpreta o caráter lingüístico da obra de arte como um horizonte de sentido, simultaneamente anterior e posterior com relação à linguagem comunicativa. Sobre a linguagem da arte, Adorno afirma: "é mais antiga" que a linguagem significativa, mas "ainda não foi cumprida", está suspendida (Uneingelöstes). Como compreender esta aparente contradição? A chave está naquilo que as obras fazem através de sua estruturação: "repetem o surgimento do sujeito". Podemos explicar esta afirmação a partir do anteriormente dito sobre o momento construtivo das obras de arte. Ao carecer as obras de arte das garantias que possui, para a formação e articulação dos elementos significantes, a linguagem convencional utilizada pelos falantes para comunicar-se, sua estruturação significante enfrenta ao sujeito com uma tarefa análoga a seu difícil advir à linguagem. A originalidade dos signos da arte obriga os homens já socializados pela linguagem a repetir o processo de sua socialização; como se fossem forçados, pela estruturação interna desses 
"signos estranhos", a aprender a falar novamente, repetindo assim a "pré-história" de sua subjetividade. Desta perspectiva, as obras de arte obrigam aos homens a caminhar no escuro, a decidir sem a guia de uma regra pré-existente sobre o significante e o insignificante, sobre o que tem valor e o que não tem valor, sobre o que deve aceitar-se como formado e consistente, e aquilo que deve desconsiderar-se enquanto informe e inconsistente. Ao ficar, deste modo, detidas no momento da produção dos horizontes de sentido, as obras de arte circunscrevem - sugere Adorno - isso que o uso comunicativo da linguagem desloca e oculta constantemente: a violência que foi necessária para fazer surgir a convenções e as regras simbólicas da sociedade. Esse processo, que faz parte da "préhistória" do sujeito e da "pré-história" da linguagem comunicativa, é o que se exprime na estruturação interna das obras de arte. É nesse sentido, então, que elas são "mais antigas" que a linguagem com a qual os sujeitos se comunicam, e se "estremecem com a pré-história da subjetividade".

Porém, segundo Adorno a linguagem da arte também deve ser compreendida como uma estrutura em suspenso, ainda não realizada. Para entender por que Adorno insiste em afirmar que a linguagem da arte "ainda não foi cumprida", pode ser frutífero comparar os signos estranhos da arte com os signos estranhos da história. Os últimos compartilham com os signos da arte a primeira determinação temporal que Adorno propõe, isto é, são mais antigos que o horizonte atual de sentido. Entretanto, eles diferem dos signos da arte no que diz respeito à segunda determinação temporal, pois os signos da historia já "cumpriram" no passado sua consumação como linguagem, já formaram parte de um mundo cultural por legitimo direito. Neste ponto da relação hermenêutica é preciso distinguir o estranho de um rastro do passado ou de um resto civilizatório, em relação aos signos históricos, e o estranho de um olhar presente, que é para Adorno a instância da significação na arte. No primeiro caso, a fusão do horizonte próprio com o alheio pode realizar-se através da reconstrução dos elos dessa linguagem (total ou parcialmente) perdida, mediante a indagação histórica e a acumulação de vestígios sucessivos. Assim, as ruínas de um velho edifício requerem que a imaginação acrescente ao que está presente as partes ausentes, segundo o curso que seus próprios vestígios vão indicando; requerem um acompanhamento do "diálogo" que ainda existir, de maneira mais ou menos evidente, com outros edifícios dos arredores; e requerem, finalmente, do conhecimento possível sobre a disposição total da 
cidade na época em que aquele edifício formava parte da vida. Pelo contrário, o contexto da arte segundo Adorno "ainda não foi cumprido", nunca chegou a consumar o círculo de suas relações, nem pôde efetuar inteiramente o diálogo de suas figuras. Neste sentido, o que está presente na obra de arte não pode ser interpretado como um vestígio de uma misteriosa linguagem ausente (que estaria completa em outro lugar). A alteridade da experiência estética frente ao horizonte próprio do espectador não vem dada, como no caso da experiência histórica, do fato de ela ter que dirigir seu olhar para uma realidade estranha, mas sim do fato de um olhar estranho se voltar para sua própria realidade. O poema completo de Rilke que menciona Adorno, Torso arcaico de Apolo, nos permite compreender melhor a presença desse olhar ausente:

Não sabemos como era a cabeça, que falta,

De pupilas amadurecidas, porém

$\mathrm{O}$ torso arde ainda como um candelabro e tem,

Só que meio apagada, a luz do olhar, que salta

E brilha. Se não fosse assim, a curva rara

Do peito não deslumbraria, nem achar

Caminho poderia um sorriso e baixar

Da anca suave ao centro onde o sexo se alteara.

Não fosse assim, seria essa estátua uma mera

Pedra, um desfigurado mármore, e nem já

Resplandecera mais como pele de fera.

Seus limites não transporia desmedida

Como uma estrela; pois ali ponto não há

Que não te mire. Força é mudares de vida."

\footnotetext{
* Tradução de Manuel Bandeira. Rilke, R., "Torso arcaico de Apolo", in: Sämtliche Werke I, ed. E. Zinn, Wiesbaden, 1955, pág. 557 (Archaischer Torso Apollos): "Wir kannten nicht sein unerhörtes Haupt, / darin die Augenäpfel reiften. Aber / sein Torso glüht noch wie ein Kandelaber, / in dem sein Schauen, nur zurückgeschraubt, // sich hält und glänzt. Sonst könnte nicht der Bug / der Brust dich blenden, und im leisen Drehen / der Lenden könnte nicht ein Lächeln gehen / zu jener Mitte, die die Zeugung trug. // Sonst stünde dieser Stein entstellt und kurz / unter der Schultern durchsichtigem Sturz / und flimmerte nicht so wie Raubtierfelle; // und bräche nicht aus allen seinen Rändern / aus wie ein Stern: denn da ist keine Stelle, / die dich nicht sieht. Du mußt dein Leben ändern."
} 
O poema não poderia ter sido escolhido melhor. Nesta poesia de Rilke, que pretende apresentar o olhar da arte, este aparece imediatamente como algo estranho, porque depende de uma situação absolutamente estranha: trata-se de um olhar que não se sustenta numa cabeça. Seus olhos estão ausentes, suas pupilas não se dilatam diante de nós e, entretanto, não deixa de nos olhar (denn da ist keine Stelle, die dich nicht sieht). A primeira interpretação que sugere o poema, então, é que o olhar da arte não é idêntico ao nosso olhar, vale dizer, que a unidade desse olhar não é a unidade de nosso olhar, por muito que os dois sejam a condição hermenêutica que evita a queda da pedra no "desfigurado e no breve" (Sonst stünde dieser Stein entstellt und kurz). O que é preciso entender é que, efetivamente, esses dois olhares sustentam alguma coisa no horizonte do sentido, mas a sustentam de modo diferente. Nosso olhar sustenta seus objetos e se posiciona frente a eles porque ele está, por sua vez, sustentado; na arte, esse ponto de apoio é extremamente frágil e, entretanto, não deixa de "deslumbrar" (Sonst könnte nicht der Bug der Brust dich blenden). Nós, enquanto espectadores, temos uma "cabeça" (hermenêutica) que é a que nos permite olhar, e através da qual o simplesmente observado é completado pelo ouvido, tocado, lembrado, anhorado, etc., que se depositam na língua e se prolongam, a partir dela, em cada novo olhar. O olhar da obra de arte - sugere Rilke - não possui este tipo de suportes hermenêuticos, mas isso não lhe impede de transpor os limites de sua materialidade e projetar-se como algo significativo sobre nós (und bräche nicht aus allen seinen Rändern aus wie ein Stern). Adorno se refere a essa falta de suporte do olhar da arte quando afirma que a linguagem que poderia dar-lhe forma, sustentá-la e completá-la: “ainda não foi cumprida”. Sua singularidade é precisamente essa: projeta-se como um olhar portador de sentido, mas carece do auxílio para produzir esse sentido, que é aquilo que toda linguagem estruturada fornece. Como entender esta situação?

Tanto o poema de Rilke quanto a passagem citada de Adorno sugerem uma resposta possível, que esclarece o paradoxo temporal que situa a linguagem da arte como algo "mais antigo que a linguagem comunicativa" e, ao mesmo tempo, como algo que "ainda não foi cumprido". A alusão explícita ao poema feita por Adorno: "denn da ist keine Stelle, die dich nicht sieht", mostra algo que ainda não tivemos em conta, isto é, que o olhar da arte que está em questão se dirige essencialmente para quem a contempla. Quer dizer, esse olhar ao qual se referem tanto Adorno quanto Rilke não constrói seu próprio mundo de objetos e 
de posições frente a esses objetos, diferentes dos nossos e dos de nossa língua. Sob esta perspectiva, o olhar da arte não é outra cosmovisão. Não é um horizonte de sentido completo que existe entre outros horizontes de sentido completos, só que a uma certa distância de nos. A diferença consiste em que as obras de arte só são capazes de olhar-nos, de olhar-nos enquanto olhamos. Quer dizer, elas sustentam algo, mas somente o sustentam em nós, ao modo de uma interrogação sobre nosso olhar: elas nos olham olhando. Esta reflexividade que as obras devolvem àqueles que as contemplam é experimentada como uma ausência e uma petição: "Du mußt dein Leben ändern", que é como dizer: "Deves mudar para poder me compreender, não há mais remédio".

Deste modo ficam associadas as duas determinações do momento miméticoconstrutivo da obra de arte: a negação da linguagem comunicativa e a interrogação sobre o espectador. Como vimos, a estruturação dos signos estranhos da arte, que não depende de um código convencional, os faz aparecer in statu nascendi, como se repetissem o surgimento da linguagem para o sujeito através da "disposição de seu ser" (durch ihr Gefügtsein). E é precisamente esta repetição que realiza a obra de arte a que força uma reflexão sobre os signos ordinários, que eles não contêm em sua própria articulação como linguagem comunicativa. Por isso Adorno pode comparar a disposição da unidade da obra de arte com um olhar, um olhar sobre nós: ao articular ativamente o significante e o insignificante de um material determinado, ela nos olha olhando, quer dizer, nos interroga sobre nosso modo habitual de compreender (ou seja, de sentir, de proceder, de articular, de valorar). A arte se transforma, deste modo, numa linguagem (pois é uma estruturação significante) mais antiga que a linguagem comunicativa e, ao mesmo tempo, numa linguagem incompleta, ainda não realizada, em suspenso (pois não oferece outra cosmovisão, nem o suporte de um horizonte de sentido completo).

Por sua afinidade e sua distância em relação à produção de sentido nas outras esferas da vida, o momento construtivo conduz para uma significação estranha e para uma significação autônoma, ambas operando como críticas silenciosas de nosso modo de compreensão automatizado. Agora é possível enxergar, então, a relação que une a atividade significante, o sentido e o tempo. A partir da componente construtiva da obra de arte, o material significante é selecionado e articulado sem que exista sujeição, no momento dessa formação, a códigos de significação preexistentes. Assim, o sentido de sua unidade se 
transforma em algo problemático, relativamente incompreensível para a compreensão (automática). Esta estranheza dos signos da arte não só exige uma renovada série de interpretações, mas também uma renovação do próprio horizonte interpretativo, como condição necessária para a compreensão (essa é a petição do poema de Rilke: "Deves mudar" para poder me compreender). Neste caso, o tempo da compreensão dilata-se, bifurca-se e intensifica-se, pela atividade reflexionante suscitada pela estruturação interna das obras de arte.

Já podemos, neste nível, explicar aquilo que propusemos, ou seja, vincular o estranhamento estético com o caráter processual e desautomatizante da compreensão. Entretanto, não deveríamos deter aqui a busca. Adorno nos incita a suspeitar da identificação absoluta entre a negatividade estética e o momento mimético-construtivo da obra de arte. De fato, podemos constatar como segue operando aqui, solapadamente, uma determinação essencial da compreensão identificadora que Adorno queria pôr em questão: a organização teleológica da estrutura de sentido. A significação autônoma dos signos estranhos da arte não deixa de ter uma significação teleológica, que pode exigir diferentes e mais demoradas aproximações, mas que, enquanto tal, admite como finalidade o fato de ser compreendida. A difícil repetição da unidade do signo é, ela própria, uma unidade de sentido, tortuosa e frágil, mas que tem como horizonte uma significação possível. Reclama desde dentro de nosso próprio horizonte de sentido uma nova perspectiva para o sentido, mas essa realização é jogada num tempo teleologicamente concebido. O núcleo temporal da obra de arte permaneceria delimitado assim se nele interviesse, unicamente, o momento construtivo (que Adorno também pensa como sua "racionalidade imanente"). Entretanto, como já antecipamos, Adorno concebe este momento exclusivamente ao interior de uma relação dialética com seu oposto, o denominado momento mimético-expressivo, que vai aparecer em cena para interferir nessa articulação e interpretação da processualidade da obra de arte, entendida como uma prolongação e uma bifurcação da significação no tempo normal da compreensão automática. 


\section{b2.- O momento mimético-expressivo}

Contrariando alguns preconceitos da teoria estética moderna, Adorno não duvidou em retomar os conceitos de mimesis e expressão, para estabelecê-los como conceitos centrais de sua Teoria Estética. Nesta nova conjunção, a mimesis transforma-se no outro e no oposto do princípio que constrói a aparência estética, e se torna uma força "préespiritual e contrária ao espírito" (ÄT: 180). Se caracterizarmos o momento construtivo da mimesis estética como aquele que tende para a estruturação do caráter simbólico das obras de arte, devemos compreender o momento mimético-expressivo como seu contrário, como aquele que exige à estética "não entender as obras de arte como objetos hermenêuticos"

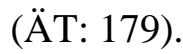

Adorno pensa a especificidade da experiência estética não só no sentido de uma “espiritualização" singular dos materiais artísticos, mas também como negação do espírito, que as obras de arte realizam enquanto instâncias de resistência e rejeição do espírito dominador da natureza: "Pois enquanto negação do espírito dominador da natureza, o espírito nas obras de arte não se apresenta como espírito, mas inflama-se no contraposto a

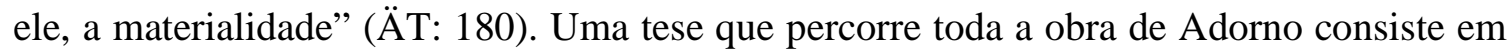
afirmar que a arte é o refúgio do comportamento-mimético, que persevera no interior das formas racionalizadas de vida "como lugar-tenente da vida não danificada em meio da vida danificada" (Statthalter unbeschädigten Lebens mitten im beschädigten, ÄT: 179). Deste lado da dialética interna da obra de arte, a mimesis persevera e potencia sua contradição com a racionalidade. Por isso, se se pensar a obra de arte - como faz repetidamente Adorno - como uma unidade de forças centrípetas (que tendem para a unidade de sentido) e forças centrífugas (que a desorganizam, rebelando-se contra a significação) ${ }^{130}$, a componente

\footnotetext{
${ }^{130}$ Cfr., Adorno (ÄT), 449: "Die philosophische Konstruktion des einsinnigen Vorrangs des Ganzen vor dem Teil ist der Kunst so fremd wie erkenntniskritisch unhaltbar. Keineswegs gehen in bedeutenden Werken die Details spurlos in der Totalität unter. Wohl ist die Verselbständigung der Details, sobald sie, gleichgültig gegen den Zusammenhang, diesen zum subsumierenden Schema erniedrigt, von Regression ins Vorkünstlerische begleitet. Aber vom Schematischen unterscheiden produktiv sich die Kunstwerke einzig durch ein Moment von Selbständigkeit ihrer Details; jedes authentische Werk ist die Resultante zentripetaler und zentrifugaler Kräfte. Wer in der Musik mit den Ohren nach schönen Stellen jagt, ist ein Dilettant; wer aber schöne Stellen, die in einem Gebilde variierende Dichte von Erfindung und Faktur nicht wahrzunehmen vermag, ist taub. Differenzierung innerhalb eines Ganzen nach dem Intensiven und
} 
mimético-expressiva deve ser pensada, decididamente, enquanto motor principal destas últimas; elas conseguem assim "a expressão do que não tem expressão (dem Ausdruck des

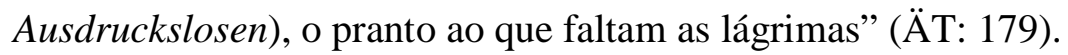

A categoria kantiana do sublime pode servir de guia para entender este outro pólo da obra de arte. Evidentemente, a idéia de negatividade estética de Adorno toma desta categoria a radicalidade de uma força dissolvente que violenta o sujeito e ameaça com sua desintegração. Kant pensou a experiência do sublime sob a forma de um estremecimento radical, que tirava o terreno firme para a atividade coordenada do sujeito de conhecimento. ${ }^{131}$ Literalmente, a coisa sublime é aquela que "tira o chão" do sujeito, fazendo com que ele caia. Pois bem, Adorno conserva esta idéia, mas modifica a explicação da causa do estremecimento. De maneira diferente ao que expõe a tese kantiana, Adorno afirma que aquilo que faz estremecer na experiência do sublime não é a inusitada superioridade da subjetividade frente ao ser natural, mas sim a semelhança do sujeito com a natureza:

Ao contrário do que pretendia Kant, o espírito percebe diante da natureza menos sua superioridade do que a sua própria semelhança com a natureza. Este instante leva o sujeito ao pranto em frente ao sublime. A lembrança da natureza (Eingedenken von Natur) dissolve a obstinação da auto-posição (Selbstsetzung): “A lágrima brota, a terra tem-me de novo!”. Desse modo o eu salta, espiritualmente, fora de seu cativeiro em si mesmo (Darin tritt das Ich, geistig, aus der Gefangenschaft in sich selbst heraus). Cintila algo da liberdade que a filosofia reserva com erro culpável ao contrário, à soberania do sujeito. $\mathrm{O}$ feitiço que a soberania lança ao sujeito também a ele apanha: a liberdade se agita na consciência de sua semelhança com a natureza. Dado que o belo não se subordina à casualidade natural que o sujeito impõe aos fenômenos, seu âmbito é aquele de uma liberdade possível (eines möglicher Freiheit). (ÄT: 410, grifos meus)

Sekundären war bis zur jüngsten Entwicklung ein Kunstmittel; die Negation des Ganzen durchs Teilganze ihrerseits vom Ganzen gefordert."

${ }^{131}$ I. Kant, Kritik der Urteilskraft, pág. 165: "Der wichtigste und innere Unterschied aber des Erhabenen vom Schönen ist wohl dieser: daß, wenn wir, wie billig, hier zuvörderst nur das Erhabene an Naturobjekten in Betrachtung ziehen (das der Kunst wird nämlich immer auf die Bedingungen der Übereinstimmung mit der Natur eingeschränkt), die Naturschönheit (die selbständige) eine Zweckmäßigkeit in ihrer Form, wodurch der Gegenstand für unsere Urteilskraft gleichsam vorherbestimmt zu sein scheint, bei sich führe, und so an sich einen Gegenstand des Wohlgefallens ausmacht; statt dessen das, was in uns, ohne zu vernünfteln, bloß in der Auffassung, das Gefühl des Erhabenen erregt, der Form nach zwar zweckwidrig für unsere Urteilskraft, unangemessen unserm Darstellungsvermögen, und gleichsam gewalttätig für die Einbildungskraft erscheinen mag, aber dennoch nur um desto erhabener zu sein geurteilt wird." 
O momento mimético-expressivo da obra de arte é perfeitamente compatível com esta descrição negativa do sublime. Quando Adorno se refere à famosa passagem do Fausto de Goethe ("Die Thräne quillt, die Erde hat mich wieder!",132), opõe-se estrategicamente a todas as interpretações afirmativas e mitológicas que procuram fatidicamente a idéia de "lembrança da natureza". A afinidade e a semelhança com a natureza é um momento, um estremecimento, essencialmente liberador e negativo (Darin tritt das Ich, geistig, aus der Gefangenschaft in sich selbst heraus). Segundo pensa Adorno, a lembrança da natureza na arte não é um retorno à natureza, quer dizer, um salto positivo, que se materializaria na arte enquanto última decisão de recair na pura faticidade, na procura do afastamento das constrições da racionalidade - como sustenta a crítica de Habermas, que associa apressadamente Adorno com o neo-vitalismo nietzscheano. A passagem que acabamos de citar resulta fundamental para esclarecer esta questão. Adorno afirma que a lembrança da natureza que efetua a obra de arte dissolve a auto-posição do sujeito, mas evita dizer que nesse movimento se afirmaria a natureza no eu. Pelo menos em princípio, a saída, a fuga ou o salto fora (heraustreten) do cativeiro que a soberania (da racionalidade) do sujeito impõe ao eu, não implica uma afirmação de outra coisa, um lugar definido ao qual se retornaria $\operatorname{logo}$ do salto. Para que a conjunção proposta entre o sublime e o Eingedenken $^{133}$ da natureza não se confunda com a doutrina da vontade de poder, Adorno reforça sua idéia afirmando que, no estremecimento mimético, o que se produz é um salto espiritual (Darin tritt das Ich, geistig, heraus). Quer dizer, uma dissolução da "soberania do sujeito" que aponta para o "âmbito de uma liberdade possível”.

É necessário pensar o momento mimético-expressivo nesta linha desta interpretação do sublime. Com seu comportamento mimético, as obras de arte envolvem internamente, sem suprimi-lo, aquilo que se opõe a elas. Quando este comportamento é vigoroso, produz

\footnotetext{
132 Göthe, J.W., Faust, pág. 55 (784): "Ein unbegreiflich holdes Sehnen / Trieb mich durch Wald und Wiesen hinzugehn, / Und unter tausend heißen Thränen, / Fühlt' ich mir eine Welt entstehn. / Dieß Lieb verkündete der Jugend muntre Spiele, / Der Frühlingsfeyer freyes Glück; / Erinnrung hält mich nun, mit kindlichem Gefühle, / Vom letzten, ernsten Schritt zurück. / O! tönet fort, ihr süßen Himmelslieder! / Die Thräne quillt, die Erde hat mich wieder!".

133 Para uma análise desta categoria em Walter Benjamin e sua influência em Adorno, ver: Matos, O., Os arcanos do inteiramente outro, ed. Brasiliense, São Paulo, 1989, pp. 51-58.
} 
uma "lembrança da natureza" nas obras de arte, que dissolve sua estruturação simbólica e delimita um novo âmbito de ação para os materiais. O momento mimético-expressivo pode ser exposto adequadamente, então, como a força centrífuga que faz aparecer, em cada parte da obra, a materialidade da qual foi extraída para dar-lhe forma à aparência estética. Esta "lembrança da natureza" nos signos da arte é radicalmente negativa, porque faz estremecer os significantes da obra e os abre a relações de semelhança e afinidade alheias à unidade autônoma da obra, estranhas em relação às suas próprias pretensões de articulação imanente. Quando opera esta força mimética, cada uma das partes da obra se comporta como se olha-se para fora, desfazendo seus compromissos com as outras partes e com o todo que as transformava em seus membros. A arte radical desdobrou este momento de distintas formas: como cores puras que se inserem nos quadros sem nenhum valor simbólico, como ênfase na materialidade dos sons que repelem e esvaziam as palavras de qualquer conteúdo semântico, como imagens que perdem seu marco, se transformando em puras superfícies, volumes e objetos sem nenhum valor significante, etc. Poder-se-ia dizer que, neste outro pólo da obra de arte, a mimesis toca a ferida entre o significante $e$ o material significante, produzindo assim o gesto através do qual realiza uma expressão singular. É deste modo que pode ser interpretada a tese de Adorno que atribui uma qualidade expressiva à mimesis, e que associa decididamente essa expressão com o momento dissonante das obras de arte.

Quando Adorno pensa a mimesis como uma força centrífuga que quebranta seu centro de gravidade e sua logicidade, o que faz é introduzir na interpretação estética o jogo de uma alteridade radical. Este outro pólo da dialética interna das obras de arte já não repete de maneira diferente e reflexiva as articulações de sentido que na linguagem comunicativa circulam como identidades fechadas e irrefletidas. O momento miméticoexpressivo não só nega as articulações dos signos convencionais, mas também nega as articulações de sentido autônomas das próprias obras de arte. Mediante o momento mimético, o percurso de leitura encontra uma linha de avanço idêntica a uma linha de desvanecimento, um percurso negativo, que apaga as marcas significantes do traço. Nesta dimensão da mimesis, já não é possível falar de uma negação parcial do sentido, efetuada 
por um signo estranho que exige outro marco interpretativo para realizar a decifração de seu sentido. Trata-se, agora, do "desmoronamento" (Zerfall) do sentido. ${ }^{134}$

A lógica do desmoronamento do sentido que a mimesis introduz transcende os limites da negação determinada, que servia para apresentar a alteridade do momento construtivo da arte em relação às formas ordinárias de compreensão automática. $\mathrm{O}$ desmoronamento mimético do significante não supõe nenhuma oposição ou contradição relativa entre a arte e o que não é arte. Não opõe ao significante convencional outro significante; nada particular se mobiliza, que permita entrar num jogo de oposições recíprocas com as identidades estabelecidas. Em troca, trata-se de uma dissolução dos elos que estruturam os signos, que consegue por esse meio, paradoxalmente, tornar-se expressiva. Esta desarticulação do sentido radicaliza a negação da linguagem comunicativa e se transforma no gesto da arte. Para Adorno, é exatamente esta estranha expressividade da arte a que não pode ser compreendida quando se interpretam as obras de arte exclusivamente como objetos hermenêuticos:

Que as obras renunciem à comunicação é uma condição necessária, mas não suficiente, de sua essência não ideológica. $\mathrm{O}$ critério central é a força da expressão através de cuja tensão as obras de arte falam com um gesto sem palavras. Na expressão se revelam como cicatriz social (gesellschaftliches Wundmal); a expressão é o fermento social de sua figura autônoma. (ÄT: 353)

O momento mimético-expressivo é apresentado aqui como uma peculiar negação da negação, isto é, como uma negação que radicaliza a negatividade. Se o momento construtivo da obra de arte negava a linguagem comunicativa a partir da estruturação de signos estranhos, vemos agora que o momento mimético-expressivo pode ser adequadamente concebido como uma negação interna das pretensões dessa significação autônoma. Em relação com a linguagem comunicativa, esta dupla negação procede assim: a primeira negação nega a vigência socialmente aceita dos signos e das regras que organizam o sentido ao inscrever no "espaço público" signos estranhos que instituem uma instância reflexiva no sujeito; a segunda negação destitui o sujeito reflexionante e torna radicalmente impossível o momento do sentido, ao desmoronar as operações significantes das obras em

\footnotetext{
${ }^{134}$ Cfr., Adorno (ÄT): 266.
} 
seus materiais constitutivos. Com esta segunda negação, as obras destituem a pretensão da arte de possuir uma esfera de validez autônoma e produzem, ao mesmo tempo, a força de sua expressão autônoma. Combatendo a "má abstração" das esferas de valor, as obras se transformam em cicatrizes sociais daquilo que a tecnificação cultural do processo de racionalização oculta e destrói: "Statthalter unbeschädigten Lebens mitten im beschädigten".

c) A dialética negativa da arte.

A estrutura dos dois momentos (o momento mimético-construtivo e o momento mimético-expressivo) que acabamos de analisar nos revelou duas formas de negatividade implicadas na experiência estética: a negação determinada e a negação radical que Adorno chama "desmoronamento". Ora bem, Adorno não pensa ambos os momentos como momentos separados, mas os concebe como momentos de uma relação dialética. De fato, é a dialética entre estes dois momentos a que explica o caráter processual da obra de arte e sua oposição específica à compreensão identificadora que organiza as outras esferas culturais. A tese adorniana afirma que, ao reunir ambos os momentos, as obras de arte "sintetizam momentos incompatíveis (unvereinbare), não idênticos, em fricção" (ÄT: 263). E essa capacidade para reunir momentos que não podem ser reunidos é a que vai forçar as obras de arte a procurar sua identidade processualmente:

O caráter processual das obras de arte constitui-se mediante o fato de elas, enquanto artefatos, enquanto algo feito pelos seres humanos, terem de antemão o seu lugar no «reino autóctone do espírito»; mas, para se tornarem idênticas a si mesmas, precisam do seu nãoidêntico (ihres Nichtidentischen), do heterogêneo, do não já formado. A resistência da heteridade (Andersheit) contra elas, à qual, no entanto, estão vinculadas, move-las a articular a própria linguagem formal e a não deixar nada que não esteja formado. Esta reciprocidade constitui a sua dinâmica; o caráter inconciliável da antítese faz que aquela não se atenue em nenhum ser. ( $\ddot{T}$ : 263)

Em nossa reconstrução anterior analisamos separadamente as tendências que agora aparecem reunidas, induzindo o caráter processual da obra de arte. Com efeito, vimos que o momento mimético-construtivo é aquele que tende para a formação dos significantes 
estranhos da arte, transmitindo-lhes o imperativo de sua unidade formal. Por sua vez, o momento mimético-expressivo é aquele que desestructura essa formação, introduzindo uma heterogeneidade radical. Pois bem, a peculiaridade da obra de arte consiste, para Adorno, em sua capacidade para reunir ambos os momentos sem que se anule ou "caráter inconciliável da antítese", quer dizer, sem que devam pagar o preço de sua neutralização num resultado. Noutra passagem da Teoria Estética, Adorno associou ambos os momentos da obra de arte com uma dupla tendência constitutiva: a tendência de "não-querer-sercompreendida" (Nicht-sich-verstehen-Lassen) e a tendência de "querer-ser-compreendida" (Verstanden-werden-Wollen). ${ }^{135} \mathrm{O}$ momento mimético-construtivo é o que abre a possibilidade de que as obras sejam compreendidas, estruturando um processo significante que solicita uma compreensão por parte de quem as contempla. Do outro lado, o momento mimético-expressivo é o que resiste essa compreensão, não deixando que o processo se resolva numa interpretação. Pretendo, a seguir, sistematizar brevemente esta peculiar dialética da arte.

Para diferenciar a esfera autônoma da arte das outras esferas da modernidade cultural, partimos do caráter enigmático da obra de arte. Esta condição é algo geralmente reconhecido. Virtualmente nenhuma posição teórica que analise as diferenças internas da cultura moderna nega o fato de que o que distingue a esfera artística é a dificuldade, a ambigüidade, e, em definitivo, a estranheza de seus signos se comparados com os signos que servem para produzir os enunciados, por ex., da moral ou da ciência. O que varia é, evidentemente, a interpretação desse caráter enigmático da arte, isto é, a explicação de por que e como as formações simbólicas da arte se estruturam de modo diferente. Em si mesma, a categoria de enigma resulta, portanto equívoca e ameaça com dissolver a diferença da arte em uma forma ampliada de racionalidade ou com jogá-la imediatamente ao irracionalismo.

A proposta de Adorno consiste em afirmar que o caráter estranho dos signos da arte não deve ser considerado como algo que exista em si, ao modo de uma propriedade fixada neles, mas sim como o efeito do processo intrínseco das forças que o constituem. Deste modo, Adorno responde uma pergunta freqüentemente esquecida, ou remetida a uma

\footnotetext{
${ }^{135} \operatorname{Ver}$ Adorno (ÄT): 448.
} 
origem misteriosa: por que o caráter lingüístico da obra de arte difere de nossa linguagem como meio de comunicação? Por que as obras de arte se obstinam em não falar francamente a língua dos homens? Em vez de aceitar essa diferença como pressuposto, ou remeter indistintamente à categoria dos signos hermeneuticamente difíceis, Adorno explica geneticamente sua singularidade. Sua resposta é a dialética entre os momentos que reconstruímos acima, quer dizer, a dialética entre o momento mimético-construtivo e o momento mimético-expressivo: é porque incorporam, sem poder anulá-la, uma força dissolvente que arruína suas estruturações simbólicas desde dentro, que as obras de arte vêem- se obrigadas, em seu modo de aparecer, a começar sempre novamente a formação de seus significantes. Se a estranheza dos signos da arte consiste em que eles, se comparados com os signos da linguagem comunicativa, aparecem in statu nascendi, isso é assim porque opera internamente o estremecimento mimético, a dissolução das partes significantes, que produz neles uma tendência para a materialidade, para o insignificante. Esta dialética supõe, ao mesmo tempo, que essa dissolução nunca é absoluta, quer dizer, que a pretensão da lei formal que tenta instituir o momento construtivo recomeça o trabalho sobre esses materiais liberados. O caráter processual do sentido na obra de arte provém da tensão irreconciliável entre ambos os momentos.

Se imaginarmos sobre uma linha de tempo o que nas obras aparece sincronicamente, poderíamos representar a não resolubilidade da dialética entre o momento miméticoconstrutivo e o momento mimético-expressivo como uma sequiência que se reinicia permanentemente. Em primeiro lugar, teríamos que localizar a seleção e articulação dos materiais vão adquirir, graças à lei formal da obra, um valor significante. Esta formação de significantes por parte das obras de arte estabelece sua condição de querer ser compreendidas. $\mathrm{O}$ momento dessa compreensão seria idêntico à fusão entre o horizonte estranho aberto pela obra de arte e o horizonte de sentido estabelecido que os sujeitos compartilham. Quer dizer, as obras de arte aparecem como uma estrutura simbólica que solicita uma interpretação, mas exigem um contexto renovado, um esforço que o sujeito ainda deve produzir. A particularidade dessa petição é a modalidade através da qual a arte acessa ao "reino autóctone do espírito". Mas o movimento não se detém aí. Frente à possibilidade de realizar essa promessa - sustenta Adorno - se levanta a heterogeneidade que introduz o momento mimético-expressivo. A "lembrança da natureza", que carrega toda 
obra de arte autêntica, dissolve as articulações formais que fazem possível essa petição e, provocando um estremecimento interno, transforma as partes significantes em materiais que já nada dizem nem prometem. Mas que proclamam, deste modo, a força que têm as obras para não deixar-se compreender, para dar um "salto espiritual" para a natureza da qual foram extraídas pelo sujeito e para o sujeito. Esses materiais, entretanto, não caem brutalmente na faticidade. Ao mover-se dentro da obra, serão novamente propostos para uma significação no momento construtivo. Por isso, Adorno se refere à dissoluçãomimética do sentido como um "salto espiritual" para a natureza, porque ela simplesmente reinicia o ciclo da formação do espírito da obra de arte, enquanto arruína a esperança de que se produza uma fusão dos horizontes de sentido enfrentados. Em conjunto, ambos os movimentos constituem o devir da obra de arte, que faz com que as obras sejam algo "que tem movimento em si mesmo"136. E esse devir interno, produto da dialética do sentido na arte, é o que rechaça e subverte os automatismos da compreensão identificadora que organiza a comunicação entre as outras esferas de valor da modernidade (ciência, moral) e determina negativamente a autonomia estética.

Como vimos, esta dupla especificidade da mimesis na arte (sua cisão em momentos contraditórios e sua capacidade para espiritualizar negativamente a "lembrança da natureza") encontra-se muito distante do papel que lhe atribui a sentença habermasiana associada à interdição do caminho de auto-clarificação da modernidade a partir da estética. ${ }^{137}$ Mas também está distante do caráter não conflitivo que denúncia a crítica de Honneth, que concebe o recurso teórico de Adorno à arte como busca de um mero refúgio frente à dominação, completamente externo em relação aos conflitos sociais e políticos da modernidade tardia. ${ }^{138}$ Contra esta interpretação estendida no campo da sociologia da

\footnotetext{
${ }^{136}$ Cfr., Adorno (ÄT), 262: "Lebendig ist ästhetische Erfahrung vom Objekt her, in dem Augenblick, in dem die Kunstwerke unter ihrem Blick selbst lebendig werden. So hat George in dem Gedicht »Der Teppich«72, einer art poétique, die einem Band den Titel leiht, symbolistisch es gelehrt. Durch betrachtende Versenkung wird der immanente Prozeßcharakter des Gebildes entbunden. Indem es spricht, wird es zu einem in sich Bewegten. Was irgend am Artefakt die Einheit seines Sinnes heißen mag, ist nicht statisch sondern prozessual, Austrag der Antagonismen, die ein jegliches Werk notwendig in sich hat. Analyse reicht darum erst dann ans Kunstwerk heran, wenn sie die Beziehung seiner Momente aufeinander prozessual begreift, nicht durch Zerlegung es auf vermeintliche Urelemente reduziert."

${ }^{137}$ Ver supra pp. 57 e ss.

${ }^{138}$ Ver supra pp. 83 e ss.
} 
cultura encontramos, na preocupação adorniana sobre os aspectos formais da arte, uma análise ampla da relação internamente conflitiva que constitui a arte, onde se joga, em todos os casos, sua relação com as regras e as convenções sociais.

O registro cultural do caráter conflitivo da constituição do social não se dá, certamente, onde Honneth o procura, quer dizer, nos temas, no uso ou na recepção das obras, mas aparece enfaticamente nos materiais e na estrutura das obras. Esta constatação se corresponde com uma das teses fundamentais da Teoria Estética, que afirma que "nas obras de arte decide socialmente o conteúdo que fala desde suas estruturas formais" (ÄT: 342). A crítica cultural de Adorno sustenta que, na modernidade tardia, "as lutas sociais, as relações de classe, deixam sua marca [nos artefatos simbólicos] ao rasgar a estrutura das

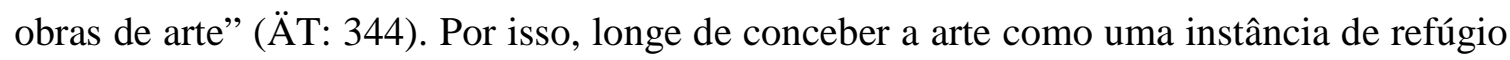
ou de fuga com respeito à dominação, Adorno pensa sua dialética interna, realizada por seus momentos enfrentados, como expressão mediada de uma conflitividade social que não pode expressar-se em outras instâncias, por outros meios: "as antinomias sociais se convertem na dialética das formas: os artistas desempenham sua função social ao ajudar as

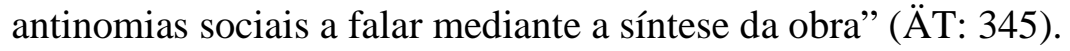

Nesta relação entre a arte e a sociedade, entre a peculiar expressividade da arte e a linguagem comunicativa, finalmente, entre a singularidade da arte e o resto das esferas de valor da modernidade, podemos perceber de que modo a "soberania da arte", sua capacidade para interagir positivamente com o mundo extra-estético, só pode exercer-se de um modo radicalmente negativo. Essa interação é mais uma função de interferência, que uma suposta "colonização" ou pratica "remitologizante" ao interior da modernidade. Justamente, por não poder se dar a forma de uma totalidade espiritual fechada, porque destitui internamente a pretensão de identidade de suas próprias unidades, torna-se expressiva daquilo que as outras esferas silenciam quando se comunicam entre si. A diferença da arte autônoma com relação às outras esferas de valor consiste, precisamente, em que seu processo imanente destrói, ao invés de afirmar, a pretensão de possuir uma esfera de validez autônoma. Esse é seu caráter paradoxal e negativo ao interior da modernidade cultural.

A diferenciação interna da racionalidade moderna pretenderia encontrar na arte um modelo (ou, pelo menos, uma promessa) de reconciliação entre o particular e o universal, 
que lhe permitisse suprir, no plano da experiência, aquilo que os conceitos dos enunciados cognitivos e morais devem abstrair, necessariamente, para poder realizar-se enquanto tais. Entretanto, para Adorno o problema colocado pela arte autônoma é outro. Ao invés de satisfazer essa promessa (que sua situação hermenêutica chega a enunciar) num reino espiritual particular, a arte autônoma demonstra, mediante o estremecimento mimético, a distância em relação às suas pretensões, a distância entre o singular e o universal, entre os materiais e as unidades significantes. A dialética dos momentos enfrentados da arte realiza ambas as coisas: a promessa de uma compreensão que não violente a singularidade do compreendido e a impossibilidade de realizar essa promessa. Nesse fracasso, que põe em marcha o curto-circuito entre seus momentos, Adorno encontra a verdadeira autonomia da arte. Esta outra autonomia, que não possui uma esfera espiritual garantida, é a que transforma as obras em "cicatrizes sociais", em modelos do não reconciliado na sociedade, silenciado nas outras esferas autônomas de valor. Por isso, Adorno pode afirmar que a dialética do momento construtivo e o estremecimento mimético é a que produz o efeito especificamente estético sobre o resto das esferas culturais: a suspeita relativa aos procedimentos por meio dos quais se consegue a identidade nas outras esferas de valor. Dado que as obras de arte só podem realizar sua própria identidade processualmente e de modo sempre incompleto, projetam-se sobre o resto das esferas culturais como uma interrogação radical, que não aceita que a identidade entre as partes tenha que ser necessariamente um resultado ou um pressuposto. Quando as obras de arte "procuram verdadeiramente a identidade do idêntico e do não-idêntico processualmente" (ÄT: 263), denunciam implicitamente como falsa a identidade das outras esferas. E é precisamente pelo tipo de descentramento que implicam objetivamente, pela tensão entre seus momentos e pela heterogeneidade com a qual enfrentam a lei que pretende dar forma à sua própria identidade, que as obras de arte podem expressar a violência circulante através dos médios que garantem a comunicação intersubjetiva, na economia, na política, na ciência, na moral e na indústria do entretenimento. Para Adorno, só neste sentido participa a arte da Ilustração da modernidade sobre si mesmo, e é nesse ponto que serve de apóio à teoria crítica. 


\section{Conclusão: Teoria estética e teoria crítica da sociedade.}

O que se pode censurar das atuais ciências do espírito como sua
insuficiência imanente: a sua falta de espírito é quase sempre, ao
mesmo tempo, uma carência de sentido estético

Theodor Adorno (ÄT: 344)

A distinção entre teoria tradicional e teoria crítica constitui o ato inaugural da "Escola de Frankfurt" na filosofia e nas ciências sociais ou, melhor dizendo, na relação que propõem e exigem entre a filosofia e as ciências sociais. Suas distintas "gerações", assim como suas diferentes posições teóricas, organizam-se em torno da possibilidade de estabelecer esse corte entre uma teoria que só se preocupa com representar o estado atual do mundo e outra que denuncia, nessa representação, um menoscabo das potencialidades reais do social. Como essa denúncia não assume um caráter prescritivo e não se transforma exclusivamente numa posição ético-política, pretende seguir aspirando a ser reconhecida enquanto teoria, cuja particularidade consiste em ser capaz de descobrir o caráter restritivo das teorias rivais. Para que a teoria crítica possa ser efetivamente uma teoria, precisa então demonstrar que a representação do mundo social que realiza a teoria tradicional não é a representação de tudo o mundo social, que há algo que excede essa representação e que não pode ser conhecido através dos conceitos e das metodologias vigentes nessa teoria. Ao mesmo tempo, a teoria crítica deveria ser capaz de oferecer uma perspectiva superadora em relação aos limites que denuncia, fazendo possível o conhecimento daquilo que ficava oculto ou era diretamente silenciado pela teoria tradicional.

Ao revisar a dialética do legado e a herança que existe entre a primeira geração da escola de Frankfurt e as posteriores gerações de teóricos que assumem essa tradição, algumas coisas se tornam imediatamente visíveis. Os dois momentos implicados no corte com a teoria tradicional, quer dizer, a crítica da ideologia na teoria e a formulação de um novo paradigma superador, recebem uma atenção marcadamente diferenciada entre os autores da primeira geração da teoria crítica e as posteriores. Na relação que existe entre Adorno e Horkheimer, por um lado, e Habermas e Honneth, por outro, isso se torna muito evidente. Adorno e Horkheimer emprestam uma atenção virtualmente excludente ao 
momento da crítica da ideologia no campo da teoria social e da filosofia, descuidando ou relevando do primeiro plano a construção de um modelo teórico alternativo. Do outro lado, tanto Habermas quanto Honneth se concentraram decididamente na formulação de novos paradigmas teóricos, dos quais, segundo inferem, deriva-se necessariamente a crítica dos momentos ideológicos da teoria tradicional, que eles não precisam prosseguir em todos seus detalhes. Desta diferença de ênfase entre - por dizê-lo assim - o momento negativo e o momento positivo do corte entre a teoria crítica e a teoria tradicional, não só derivam posições teóricas diversas ao interior de uma mesma tradição de pensamento, mas também se deduzem os problemas substanciais da própria teoria crítica. Enquanto Adorno e Horkheimer reforçam o vínculo entre a teoria crítica e o estudo das tendências sociais regressivas, Habermas e Honneth se concentram no potencial evolutivo que pode encontrarse nas sociedades atuais e que não faz parte daquilo que os mecanismos de conhecimento da ciência estabelecida permitem conhecer.

Não cabem dúvidas de que ambas as posições podem ser pensadas em termos de complementação recíproca, potencializando assim no campo da teoria crítica tanto a crítica da ideologia na teoria, quanto a reformulação do quadro teórico vigente. Nesse ponto de intercessão, poderiam achar-se múltiples problemas e conceitos em comum, fundamentalmente aqueles que convergem na rejeição da teoria positivista (em todas suas versões) e na crítica à expansão sobre o tecido social das relações de dominação que o capitalismo instituiu no centro da modernidade. Segundo nosso modo de ver, entretanto, as perguntas fundamentais da teoria crítica surgem somente quando se confrontam ambas as perspectivas, quer dizer, quando se pensa a contradição que existe entre as ênfases diferenciais que recaem sobre o momento negativo ou positivo do corte em relação à teoria tradicional.

Ao confrontar a perspectiva teórica de Adorno e Horkheimer com a de Habermas e Honneth, tomamos conta de que o viés que ambas as posições denunciam na teoria tradicional tem uma explicação completamente distinta, da qual se derivam múltiples e diferentes conseqüências teóricas (e práticas). Para estas duas posições, evidentemente, essa cisão não é casual. Quer dizer, ambas concebem a distância que separa aquilo que pode ser representado pelas teorias tradicionais e aquilo que cai fora delas como uma limitação ideológica da própria teoria social e da filosofia. Mas é justamente essa intervenção da 
ideologia na teoria a que pensam de maneira diferente. Quando Habermas e Honneth pensam o viés ideológico da teoria tradicional, o pensam como algo induzido pelas relações de poder sobre uma esfera intersubjetiva diferenciada, que é a esfera na qual os homens produzem em comum o conhecimento. Por isso, utilizam a figura da "colonização", a idéia da usurpação de um espaço que funciona de outra maneira e com outros fins. Tanto para Habermas quanto para Honneth, o viés da teoria tradicional é, então, o produto dessa influência externa no espaço de formação do saber, que termina produzindo, obviamente, efeitos no próprio conhecimento que esse espaço produz e que a teoria crítica deve procurar neutralizar e corrigir. Em troca, para Horkheimer e (sobretudo para) Adorno o viés da teoria tradicional é uma determinação intrínseca do próprio espaço de saber, vale dizer, algo que não limita ou restringe o saber, mas o constitui de dentro enquanto tal.

Desta diferença entre o caráter extrínseco ou intrínseco do viés que a teoria crítica deve assinalar na teoria tradicional, surge a diferença em relação ao conteúdo desse viés e seu campo de intervenção. Esta é a causa, em realidade, da diferença que se observa a simples vista entre as ênfases de cada uma das posições. Ao pensar o viés da teoria tradicional como uma interferência sobre (a comunicação ou o reconhecimento recíproco que constitui) o campo do saber, Habermas e Honneth estabelecem naturalmente como prioridade da teoria crítica a neutralização dessa interferência e a posta em prática de diversas estratégias conceituais orientadas a dar conta (e liberar) o conteúdo bloqueado por trás desse viés. Por isso, a ênfase se orienta, neste caso, ao desenvolvimento de um paradigma teórico renovado, que permita conhecer o potencial evolutivo bloqueado pelas relações de poder. Quer dizer, o que se manifesta nesta concepção é que o poder intervém sobre o saber que a sociedade (ou determinados movimentos ou classes sociais) pode produzir sobre si mesma, restringindo e limitando o conhecimento de suas próprias potencialidades. E são essas potencialidades, precisamente, as que permanecem cobertas (interesseiramente - ainda quando for de modo inconsciente) pelo véu da teoria tradicional.

Do outro lado, a posição de Adorno e Horkheimer se interessa por um conteúdo muito diferente. Para eles, o essencial daquilo que não pode ver a teoria tradicional não é o potencial evolutivo das sociedades que pretende conhecer, mas, pelo contrário, as tendências regressivas que essa sociedade atualmente contém. Para Adorno e Horkheimer, o que a teoria tradicional não pode fazer é integrar em seus quadros conceituais o 
conhecimento do alcance e intensidade das relações socialmente destrutivas, a pesar de seu caráter manifesto e da evidência de seus efeitos. Quer dizer, aquilo que se torna opaco a partir da intervenção da teoria tradicional não é algo potencial, que os conceitos positivistas da teoria tradicional não podem relevar, mas algo (por demais) atual que, a través da ritualização empirista e da organização interna de seus conceitos, as ciências sociais resistem-se a conhecer. Este viés já não pode ser concebido como uma interferência do poder sobre o saber, mas deve ser pensado como uma abrangente resistência à teoria, contida na dinâmica do próprio processo social. Por isso, esta interpretação do viés da teoria tradicional perde o solo firme a partir do qual poder efetuar a crítica, e parece solicitar a participação de um duvidoso olhar externo.

Desta maneira, se produz a grande divisória de águas dentro da tradição da teoria crítica, que temos examinado ao longo deste trabalho. Ela revela também por onde passam as afinidades eletivas em um e em outro caso. A opção seguida por Habermas e Honneth para produzir o conhecimento daquilo que está ausente ou bloqueado na teoria tradicional recorre, enquanto matriz que tem que nutrir a teoria crítica, à moral e à (filosofia da) ciência. Isto se vê claramente quando se analisam suas críticas à "primeira geração da Escola de Frankfurt" e as fontes teóricas que utilizam para moldar seus respectivos paradigmas teóricos. No outro extremo destas afinidades eletivas deve situar-se Adorno, que recorre decididamente à estética. Num plano puramente descritivo, então, se percebe que para criticar o viés da teoria tradicional Habermas e Honneth se valem privilegiadamente da moral e da ciência, enquanto Adorno se aproxima da estética. Esta diferença em relação às afinidades eletivas teóricas que servem para fundamentar a perspectiva crítica se corresponde com a modalidade do viés que cada uma destas posições determina. Evidentemente, tem que existir uma correspondência entre a interpretação do viés como uma interferência do poder no saber e o recurso à moral e à ciência, por um lado, e, por outro, entre a determinação do viés como uma resistência maciça à teoria e o recurso à estética. Pelas mesmas razões, podemos intuir que existe uma correspondência entre a eleição da moral e a ciência como matrizes teóricas e a determinação da teoria crítica como o esforço por conhecer o potencial evolutivo bloqueado da sociedade, por um lado, e, por outro, entre a estética e a crítica das tendências regressivas invisibilizadas pelo processo social. 
Quando Habermas e Honneth criticam, segundo a interpretação que dela fazem, a teoria tradicional, denunciando sua incapacidade para ver o conjunto da realidade social, o que extraem de sua opacidade são "partes potenciais" dessa realidade social, que existiriam efetivamente, mas enquanto forças ou capacidades sociais parciais. Conjugando uma via de análise histórica com um "trascendentalismo empiricamente controlado", eles produzem os conceitos ausentes da teoria tradicional com o fim de conhecer essas partes que a teoria tradicional desconhece ou não pode situar adequadamente em um marco teórico. Essas partes se transformam no núcleo de seus respectivos paradigmas teóricos: a ação comunicativa (livre de coações) e o reconhecimento recíproco (da dignidade individual). O conjunto de sua estratégia teórica se dirige nessa direção. Quando transpassam a fantasmagoria capitalista (da mercadoria ou da política representativa) que nubla a vista da teoria tradicional, o que descobrem é uma dimensão da práxis social que se expressa com força na cultura moderna, mas que está minguada, assediada e enfraquecida no resto das interações sociais. Por isso, tanto a ação comunicativa quanto o reconhecimento recíproco são "partes potenciais" da totalidade social. Porque são uma força e uma capacidade social que intervêm efetivamente na reprodução social e, ao mesmo tempo, porque seu desenvolvimento se encontra bloqueado pelas relações de dominação e as expectativas normativas vigentes, permanecendo portanto sua expansão para o conjunto das interações sociais como uma possibilidade objetiva, ainda não realizada.

Tanto para Habermas quanto para Honneth, a teoria tradicional reforça a debilidade das partes potenciais que a teoria crítica procura redimir, porque opera no campo da representação deslocando e invisibilizando aquelas dimensões da práxis social que, de qualquer maneira, persistem. Seu lugar privilegiado de aparição institucional na cultura moderna é a esfera pública, em sua modalidade deliberativa e/ou de luta política. A esfera pública representa para ambos pensadores o lugar mais adequado para reconstruir critérios normativos imanentes ao desenvolvimento social que sirvam para criticar a configuração efetiva das relações sociais. Temos visto que essa é a causa pela qual resulta tão sensível para esta perspectiva o lugar da distinção entre faticidade e validez dentro da lógica das ciências sociais. Essa distinção faz possível o conhecimento das partes potenciais, dado que tanto a ação comunicativa quanto o reconhecimento intersubjetivo só podem ser identificados na realidade social como forças ou capacidades para constituir interações na 
base de pretensões de validez compartilhadas. As afinidades teóricas, os conceitos e a metodologia por eles utilizados adéquam-se a este programa, e determinam a revitalização das Kulturwissenschaften no marco de sua tentativa de devolver aos homens "a capacidade para tomar a própria sociedade como o objeto de sua atividade". Também vimos que é sobre o fundo desta interpretação da teoria crítica que ambos realizam sua crítica frontal da herança de Adorno e Horkheimer. Eles não haveriam podido transpassar as fantasmagorias do capitalismo, nem vincular-se em termos positivos com o potencial evolutivo obscurecido pela teoria tradicional.

Com este enfoque, Habermas e Honneth escapam rapidamente do que, na Dialética Negativa, Adorno chamou de paralogismo da liberdade, que diz: quem afirma que "todos são por igual cegos e predeterminados" se contradiz a si mesmo, porque nega a possibilidade de exercer uma ação crítica com respeito a esse estado de coisas, que é o que ele próprio está fazendo (ND: 217). Ao associar a teoria crítica com um trabalho reconstrutivo, que parte de e retorna à perspectiva dos próprios atores sociais, ligado ao potencial evolutivo contido na moral e na ciência modernas, tanto Habermas quanto Honneth saem exitosamente desta contradição. Pelo contrário, ao associar-se à estética, Adorno "não quer sair da contradição".

Os motivos que levaram Adorno a evitar o caminho da elucidação do potencial evolutivo da modernidade são variados e já os estudamos e discutimos em detalhe. Alcança com repetir aqui só o mais relevante, que surgiu da confrontação de ambas as perspectivas. Tanto para ele quanto para Horkheimer, a cultura moderna opera em termos repressivos através de (e não apesar de) as pretensões com as quais a indústria cultural organiza as interações comunicativas e as formas de reconhecimento recíproco socialmente válidas. Longe de poder transformar-se em critério adequado para a "perspectiva emancipadora" da teoria crítica, essas "potencialidades" se realizam nas sociedades modernas através de uma linguagem completamente fossilizada pelo próprio uso comunicativo e de uma estrutura de reconhecimento que integra seus membros através da ameaça da exclusão. Tanto a ação comunicativa quanto o reconhecimento recíproco são efetivamente imanentes a toda sociedade, mas não constituem, por si mesmos, uma instância capaz de resistir e opor-se às formas vigentes de violência e dominação. Funcionam dentro do mesmo registro de controle da população que o dinheiro e o poder. 
Por "não querer sair da contradição" da liberdade, Adorno formula sua versão da teoria crítica nos termos de uma dialética negativa. As afinidades teóricas, os conceitos e a metodologia desta estratégia teórica já não se orientarão no sentido do esclarecimento imanente do potencial evolutivo da sociedade, mas pretendem fazer experimentáveis e cognoscíveis as tendências regressivas que a constituição interna dessa sociedade torna incognoscíveis e inexperimentáveis. A recomendação básica desta modalidade da filosofia social consiste, então, em "deixar em liberdade a expressão da dor" (ND: 29). A objetividade dessa dor é o ponto cego, a "parte real" da sociedade que a teoria tradicional oculta. Não é casual (nem representa uma vocação neo-romântica), portanto, a eleição filosófica que Adorno faz pela arte autônoma.

Como a ciência ou a moral, também a arte é imanente à sociedade e permite um olhar situado e espiritualmente distanciado de seu desenvolvimento e reprodução objetiva. Mas a arte não só se distancia, por sua construção imanente, da voracidade da faticidade, mas também se distancia do modo em que a moral e a ciência, elas próprias, se distanciam. Tal como interpreta Adorno, a arte é a esfera espiritual que, ao constituir-se como esfera autônoma, não pode determinar completamente um conjunto de objetos e procedimentos espirituais específicos, mas se reproduz de modo parasitário como um momento negativo das outras esferas efetivamente constituídas da racionalidade. Quer dizer, enquanto esfera autônoma da modernidade, a arte é a esfera negativa por excelência. Por sua própria impossibilidade interna, a arte é a esfera que mais resiste a integração em um espaço simbólico único, organizado pelos princípios racionais de transparência e publicidade plena dos conteúdos que nele circulam. Ao mesmo tempo, enquanto essa resistência é ativa, a arte não só rechaça transformar-se em algo complementar à moral e à ciência, mas se expressa sobre elas como uma interferência e uma interrogação dos procedimentos que conduzem à formação, nessas outras esferas, da identidade de seus respectivos conteúdos. Isso explica o interesse teórico de Adorno pelo lugar da arte na modernidade tardia e por sua dialética interna. Ela funciona como uma crítica imanente à sociedade, que não depende de uma rígida distinção entre faticidade e validez, como a que utilizam tanto o paradigma de Habermas quanto o de Honneth. E é essa distancia em relação à distinção entre faticidade $\mathrm{e}$ validez que vai permitir a arte se transformar, pela heterogeneidade que é capaz de 
introduzir na identidade de cada obra, em expressão do sofrimento socialmente inexperimentável e incognoscível.

Vimos que o caráter processual da obra de arte tende a desmontar de dentro os automatismos dos quais depende a formação dos enunciados morais e científicos. Ao repetir de maneira processual o que na linguagem comunicativa deve funcionar necessariamente como um conjunto de evidências aproblemáticas, a arte situa a distância espiritual em relação à faticidade num lugar diferente, conduzindo o próprio conceito de espírito para uma situação paradoxal. O espírito entendido como liberdade, como diferença em relação à faticidade e como possibilidade de alcançar um acordo não violento com os outros, já não aparece como um reino constituído, mas sim como um efeito de interferência, como momento dialético e não como esfera ou ontologia especial. O que é a mesma coisa que dizer que entre as expectativas normativas institucionalizadas e as pretensões subjetivas (e intersubjetivas) não existe uma distância objetiva e garantida por outras normas e outras instituições, mas sim pela transgressão momentânea das próprias normas e das instituições, que permite dizer algo que as unidades padronizadas da linguagem comunicativa não permitem que seja dito. Adorno reforça, com esta interpretação do lugar da arte, a idéia de "liberdade possível”, que é essencial para sua versão da teoria crítica.

Ora bem, essa liberdade possível que se exprime na negatividade estética, por sua própria fragilidade, por não ser senão uma intermitência da linguagem efetivamente vigente, não conduz à experiência de uma "potencialidade evolutiva" da sociedade, que a teoria crítica teria por função redimir conceitualmente. Quer dizer, essa liberdade possível não é uma parte potencial ancorada na ontologia do social, mas uma parte negativa, que se expressa com uma linguagem enigmática nas obras de arte. Essa linguagem, como vimos, não afirma uma cosmovisão particular, mas sim interroga nossa própria maneira de olhar o mundo.

Ao mesmo tempo, pela própria estruturação de seus momentos, a linguagem das obras de arte reverte aquilo que Habermas transformou em critério que lhe permitisse sair dos paralogismos da liberdade. A linguagem das obras de arte não diz: "porque há comunicação, então não há terror", mas diz: "há terror e comunicação". Para Adorno, por sua constituição interna - isto é, a través da dialética entre seus momentos - a arte denuncia fragilmente essa conjunção. Repõe, desse modo, o que está excluído e o que a linguagem 
fossilizada do capitalismo tardio destitui da expressão. À maneira de cicatrizes sociais, as obras de arte se transformam em uma expressão indireta daquilo que está socialmente controlado pelas sanções da comunicação e as estruturas do reconhecimento. Seria essa relação com a alteridade, e não a racionalização de seu conteúdo, o que os conceitos da teoria crítica teriam que interpretar e redimir da dialética interna da arte:

Não há que confundir ciência e arte, mas as categorias que imperam nas duas não são absolutamente diferentes. Inversamente, a consciência conformista incapaz, por um lado, de distinguir as duas, não quer, por outro, reconhecer que forças idênticas atuem em esferas não idênticas. A mesma coisa se aplica à moral. A brutalidade perante as coisas é potencialmente brutalidade para com os homens. O rude (Roh), cerne subjetivo do mal, é $a$ priori negado pela arte, para a qual o ideal de plena elaboração é inalienável: isso e não a promulgação de teses morais ou a obtenção de um efeito moral é que constitui a participação da arte na moral e a associa a uma sociedade mais digna dos homens. (ÄT: 344) 
BIBLIOGRAFÍA

\section{Obras de Theodor W. Adorno.}

ADORNO, Th.: Gesammelte Schriften, Suhrkamp, Frankfurt am Main, 1997:

(PF) Philosophische Frühschriften GS1

(DA) Dialektik der Aufklärung GS3

(MM) Minima Moralia GS4

Metakritik der Erkenntnistheorie, Drei Studien zu Hegel GS5

(ND) Negative Dialektik GS6

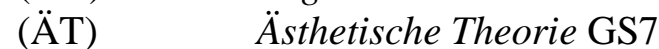

(SS I) Soziologische Schriften I GS8

(SS II) Soziologische Schriften II GS9

(KG I) Kulturkritik und Gesellschaft I GS10.1

(KG II) Kulturkritik und Gesellschaft II GS10.2

Noten zur Literatur GS11

Philosophie der neuen Musik GS12

Dissonanzen, Einleitung in die Musiksoziologie GS14

Komposition für den Film. Der getreue Korrepetitor GS 15

ADORNO, Th.: Vorlesung über Negative Dialektik, Suhrkamp, Frankfurt am Main, 2003.

ADORNO, Th.: Einleitung in die Soziologie, Suhrkamp, Frankfurt am Main, 1993.

ADORNO, Th.: Phiosophische Elemente einer Theorie der Gesellschaft, Suhrkamp, Frankfurt am Main, 2008.

\section{Traduções.}

ADORNO, Th.: Dialéctica Negativa, ed. Taurus, Madrid, 1995.

ADORNO, Th.: Disonancias. Música en el mundo dirigido, ed. Rialp, Madrid, 1966.

ADORNO, Th.: Filosofía de la nueva música, ed. Sur, Bs. As, 1966.

ADORNO, Th.: Minima moralia, ed. Taurus, Madrid, 1990.

ADORNO, Th.: Sobre la metacrítica de la teoría del conocimiento, ed. Monte Avila, Caracas, 1970.

ADORNO, Th.: Sobre la música, ed. Paidos, Barcelona, 2000.

ADORNO, Th.: Sobre Walter Benjamin, ed. Cátedra, Madrid, 1995.

ADORNO, Th.: Sociológica, ed. Taurus, Madrid, 1979.

ADORNO, Th.: Teoría Estética, ed. Taurus, Barcelona, 1971. 
ADORNO, Th.: Teoría Estética, ed. Akal, Madrid, 2004.

ADORNO, Th. y Eisler, H.: El cine y la música, ed. Fundamentos, Madrid, 1976.

ADORNO, Th.: Théorie Esthétique, ed. KLINCKSIECK, Paris, 1974.

ADORNO, Th.: Notes sur La Littérature, ed. Flammarion, Paris, 1984.

ADORNO, Th.: Teoria Estetica, ed. Einaudi, Torino, 1977.

ADORNO, Th.: Teoria Estética, ed. Martins Fontes, São Paulo, 1982.

\section{BIBLIOGRAFIA GENERAL}

ADORNO, Th. y BENJAMIN, W. 1995. Brief-Wechsel (1928-1940), Frankfurt am Main, Suhrkamp.

ARATO, A. y BREINES, P. 1986. El joven Lukács y los orígenes del marxismo occidental, ed. F.C.E, México.

AUER, D. 1998. Daß die Naturbefangenheit nicht das letzte Wort behalte. Fortschritt,Vernunft und Aufklärung, en Die Gesellschafts theorie Adornos, ed. Primus, Frankfurt.

BAZIN, A. 1999. ¿Qué es el cine?, ed. Rialp, Madrid.

BENJAMIN W. 2003. Das Kunstwerk im Zeitalter seiner technischen Reproduzierbarkeit, ed. Suhrkamp, Frankfurt am Main.

BENJAMIN, W. 1978. Ursprung des deutschen Trauerspiels, Frankfurt am Main, Suhrkamp.

BENJAMIN, W. 2003. Das Kunstwerk im Zeitalter seiner technischen Reproduzierbarkeit. Frankfurt am Main, Suhrkamp.

BENJAMIN, W. 1974. Der Begriff der Kunstkritik in der deutschen Romantik, ed. Suhrkamp, Frankfurt am Main.

BENJAMIN, W. 1998. Imaginación y sociedad. Iluminaciones I, ed. Taurus, Madrid.

BENJAMIN, W. 1998. Poesía y capitalismo. Iluminaciones II, ed. Taurus, Madrid.

BOURDIEU, P. 1979. La Distinction. Critique Sociale du Jugement, Editions Minuite, París.

BRONNER, S. 1997. Da teoria crítica e seus teóricos, Traducción R. Bueno e Cristina Meneguelo, ed. Papirus, Campinas. 
BUBNER, R. 1979. Kann Theorie ästhetisch werden?, en "Materialen zur ästhetiscen Theorie, Th. W. Adornos Konstruktion der Moderne", ed. Suhrkamp, Frankfurt.

BÜRGER, P. 2000. Teoría de la vanguradia, ed. península, Barcelona.

CALHOUN, C. (Org.). 1994. Habermas and the Public Sphere, ed. MIT Press, Massachusetts.

COHN, G. 1998. Crítica y resignación. Fundamentos de la sociología de Max Weber, ed. UNQ.

DAUß, M. 1998. Kunst ist die gesellschaftliche Antithesis zur Gesellschaft. Zum Konzept der Kunstsoziologie, en "Die Gesellschafts theorie Adornos", ed. Primus, Frankfurt.

DELEUZE, G. 2003. Lógica do sentido, ed. Perspectiva, São Paulo.

DERLIEN, H. 1991. Bureaucracy in Art and Analysis: Kafka and Weber, in Journal of the Kafka-Society of America $\mathrm{n}^{\circ} 15$.

DERRIDA, J. 1967. L'écriture et la différence, ed. Seuil.

DERRIDA, J. 1995. Espectros de Marx, ed. Trotta, Madrid.

DUARTE, R. y FIGUEIREDO, V. (comp.). 2001. Mímesis e expressão, ed. Humanitas, Belo Horizonte.

DUARTE, R. 1999. A atualidade da Crítica de Adorno, ed. Revista Educaçao e Filosofia, v $13, \mathrm{n}^{\circ} 25$.

DUARTE, R. 1997. Adorno, Nove ensaios sobre o filósofo frankfurtiano, ed. UFMG, Belo Horizonte.

DUARTE, R. 2003. Teoria crítica da indústria cultural, ed. Humanitas-UFMG, Belo Horizonte.

ESPINOZA, E. 1981. La teoría de la cosificación de Marx a la escuela de Francfort, ed. Alianza, Madrid.

FETSCHER, I. Y SCHMIDT, A. (comp.). 2002. Emanzipation als Versöhnung. Zur Adornos Kritik der Warentausch-Gesellschaft und Perspektiven der Transformation, ed. Neue Kritik, Frankfurt am Main.

FÖRSTER, J. 1998. Kunst als Staathalter der Utopie. Zum Verhältnis von Versöhnung und Unversöhnlichkeit, en "Die Gesellschafts theorie Adornos", ed. Primus, Frankfurt.

FOSTER, H. 1996. Recodificação, Casa editorial Paulista, São Paulo.

FRÜCHTL, J. 1986. Mimesis. Konstellation eines Zentralbegriffs bei Adorno, ed. Königshausen \& Neuman, Würzburg. 
GIDDENS, A. 1987. Social Theory Today, Polity Press, Cambridge.

GOMEZ, V.: 1995. La dialéctica de la Ilustración de Max Horkheimer y Theodor Adorno: una nueva lecutra, en Revista Anabasis, No 3.

GROSSNER, C. 1971. Verfall der Philosophie. Politik deuscher Philosophen, Christian Wegner, Reinbek bei Hamburg.

GRÜNER, E. 1997. Las formas de la espada, ed. Colihue, Bs. As.

GRÜNER, E. 2001. El Sitio de la mirada, ed. Norma, Bs. As..

HABERMAS, J. 1968. Technik und Wissenschaft als Ideologie, ed. Suhrkamp, Frankfurt am Main.

HABERMAS, J. 1973. Legitimationsprobleme im Spätkapitalismus, ed. Suhrkamp, Frankfurt am Main.

HABERMAS, J. 1984. Perfiles filosófico políticos, ed. Taurus, Madrid.

HABERMAS, J. 1985. Die Neue Unübersichtlichkeit. Kleine Politische Schriften V, Suhrkamp, Frankfurt am Main.

HABERMAS, J. 1987a. Teoría de la acción comunicativa I, Madrid, Taurus. [Tradução Manuel Jiménez Redondo]

HABERMAS, J. 1987b. Teoría de la acción comunicativa II, Madrid, Taurus. [Tradução Manuel Jiménez Redondo]

HABERMAS, J. 1989. El discurso filosófico de la modernidad, Madrid, Taurus.

HABERMAS, J. 1990. Strukturwandel der Öffentlichkeit, ed. Suhrkamp, Frankfut am Main.

HABERMAS, J. 2001. The liberating power of symbols, ed. MIT Press, Cambridge.

HABERMAS, J. 2005. Facticiad y Validez, ed. Trotta, Madrid.

HANSEN, M. 1992. Mass culture as Hieroglyphic Writing: Adorno, Derrida, Kracauer. New German Critique, ( ${ }^{\circ}$ 56): pp. 43-73.

HANSEN, M. 1992. Mass culture as Hieroglyphic Writing: Adorno, Derrida, Kracauer, en New German Critique N 56 (Spring/Summer).

HIRSCH, J. 1976. "Observaciones teóricas sobre el Estado burgués y su crisis", in: N. Poulantzas, La crisis del Estado, Fontanella, Barcelona. 
HIRSCH, J. 1978. "The State apparatus and social reproduction: elements of a theory of the bourgeois State", in: Holloway and Picciotto, State and capital, a Marxist debate, ed. Arnold, Londres.

HONNETH, A. 1997. The Critique of Power, ed. MIT Press, Massachusetts.

HONNETH, A. 1995. The fragmented world of the social, ed. State University of New York, New York.

HONNETH, A. 2003. Luta por reconhecimento. A gramatica moral dos conflitos sociais, ed. 34, São Paulo.

HORKHEIMER, M. 1998. Teoría crítica, ed. Amorrortu, Bs. As..

IPAR, E. 2003. "Georg Lukács y la cultura moderna", in: Las aventuras del marxismo. Dialéctica e inmanencia en la crítica de la modernidad, ed. Gorla, Bs. As.

JAMESON, F. 2007. Late Marxism: Adorno: or, The persistence of the dialectic. Londres, Verso.

JAMESON, F. 1989. Documentos de Cultura, Documentos de Barbarie, ed. Visor, Mardrid.

JAMESON, F. 1999. El giro cultural, ed. Manantial, Bs. As..

JAMESON, F. 1995. La estética geopolítica. Cine y espacio en el sistema mundial, ed. Paidós, Bs.As.

JAMESON, F. e ZIZEK, S. 1999. Estudios culturales. Reflexiones sobre el multiculturalismo, ed. Paidós, Bs. As.

JAY, M. 1984. Ideias de Adorno, ed. Cultrix, Sao Paulo.

KAES, A y LEVIN, D. 1987. "The Debate about Cinema: Charting a Controversy" (19091929). New German Critique, (No. 40, Special Issue on Weimar Film Theory): pp. 7-33.

KANT, I. 1974. Kritik der Reinen Vernunft, Suhrkamp, Frankfurt am Main.

KANT, I. 1968. Kritik der Urteilskraft, Suhrkamp, Frankfurt am Main.

KANT, I. 1974. Grundlegung zur Metaphysik der Sitten, Suhrkamp, Frankfurt am Main.

KLUGE, A. 2003. Nur das unsichtbare Bild zählt. Berliner Tagesspiegel, 11 Sept.

KOCH, G. 1989. Mimesis und Bilderverbot in Adornos Ästhetik. Ästhetische Dauer als Revolte gegen den Tod. Babylon, (N 6): pp. 36-45.

KRACAUER, S. 1989. Teoría del cine, la redención de la realidad física. Barcelona, Paidos. 
LASH, S. 1998. "Wir leben im Zeitalter der globalen Kulturindustrie", in Die Zeit/10, Feuilleton, Berlin, 26 Feb.

LUKÁCS, G. 1969. Historia y conciencia de clase. Barcelona, Grijalbo.

MARX, K. 1968. Das Kapital, in: Marx und Engels Werke, B. 23, ed. Dietz, Berlin.

MARX, K. 1968. Der achtzehnte Brumaire des Louis Bonaparte, in: Marx und Engels Werke, Bd. 8, ed. Dietz, Berlin.

MATOS, O. 1993. O iluminismo visionário: Benjamin, leitor de Descartes e Kant, ed. Brasiliense, São Paulo.

MATOS, O. 1995. Os arcanos do inteiramente outro, ed. Brasiliense, São Paulo.

MENKE, B. 1991. Sprachfiguren, Name - Allegorie - Bild nach Walter Benjamin, ed. Fink, München.

MENKE, Ch. 1997. La Soberanía del arte, la experiencia estética en Adorno y Derrida. Madrid, Visor.

MENKE, Ch. 2005. Die Gegenwart der Tragödie. Versuch über Urteil und Spiel. Suhrkamp, Frankfurt am Main.

METZ, Ch. 1971. Langage et cinéma. Paris, Larousse.

METZ, Ch. 1971-1972. Essais sur la signification au cinéma I et II, Klincksieck, Paris.

MILIBAND, R. 1977. Marxism and politics, Merlin Press, Londres.

MORRIS, M. 2001. Rethinking the communicative turn. Adorno, Habermas and the problem of communicative freedom, ed. State University of New York Press, New York.

MOUTOT, G. 2004. Langage et réification, ed. PUF, Paris.

PAETZEL, U. 2001. Kunst und Kulturindustrie bei Adorno und Habermas: Perspektiven kritischer Theorie, ed. DUV, Wiesbaden.

POULANTZAS, N. 1971. Fascismo y dictadura, Siglo XXI, México.

POULANTZAS, N. 1979. Estado, poder y socialismo, Siglo XXI, Madrid.

PRADLER, A. 2003. Das monadische Kunstwerk. Adornos Monadenkonzeption und ihr ideengeschichtlicher Hintergrund, ed. Königshausen \& Neumann, Würzburg.

RAZUMOVSKY-FASBENDER, K. 1992. Die ästhetische Rettung der Seinsgewissheit, ed. Königshausen \& Neuman, Würzburg.

RICKERT, H. 1899. Kulturwissenschaft und Naturwissenschaft, Freiburg. 
RICKERT, H. 1920. Die Philosophie des Lebens, Tübingen.

RINESI, E. 2003. Política y tragedia. Hamlet, entre Hobbes y Maquiavelo, ed. Colihue, Bs. As..

SCHULTZ, K. 1990. Mimesis on the move, Theodor W. Adorno 's concept of imitation, ed. Peter Lang, Berne.

SCHWERING, G. y ZELLE, C. (comp.). 2002. Ästhetischen Positionen nach Adorno, Wilhelm Fink, München.

SEARLE, J. 1979. Expression and Meaning, ed. University Press, Cambridge.

SEEL, M. 2004. Adornos Apologie des Kinos, in Adornos Philosophie der Kontemplation. Frankfurt am Main, Suhrkamp.

SKLOVSKI, V. 1970. El arte como artificio, in TODOROV, T. "Teoría de la literatura", Madrid, Siglo XXI.

SPENGLER, O. 1923. Der Untergang des Abendlandes: Umrisse einer Morphologie der Weltgeschichte, Munich, Beck, 2 v.

STILlA-BOWMAN, G. 2002. Darstellung und Ausdruck in der Philosophie Theodor W. Adornos. Rhetorische Strategien zwischen Subversion und Anklage, ed. Peter Lang, Frankfurt am Main.

THYEN, A. 1998. Es gibt darum in der verwalteten Welt auch keine Ethik. Moral und Moraltheorie, en "Die Gesellschafts theorie Adornos", ed. Primus, Frankfurt.

THYEN, A. 1989. Negative Dialektik und Erfahrung. Zur Rationalität des Nichtidentischen bei Adorno, ed. Suhrkamp, Frankfurt am Main.

XAVIER, I. 2005. O discurso cinematográfico. A opacidade e a transparência, ed. Paz e Terra, São Paulo.

WEBER, M. 1922. Wirtschaft und Gesellschaft, Tübingen.

WEBER, M. 1922. Gesammelte Aufsätze zur Wissenschaftslehre, Tübingen.

WEBER, M. 1987. Economía y Sociedad, ed. FCE, México.

WEBER, M. 1992. El problema de la irracionalidad en las ciencias sociales, ed. Tecnos, Madrid.

WELlMER, A. 1983. Wahrheit, Schein, Versöhnung. Adornos ästhetische Rettung der Modernität, in “Adorno-Konferenz 1983”, Frankfurt, Suhrkamp, pp. 138-176.

WELLMER, A. 1983. Wahrheit, Schein, Versöhnung. Adornos ästhetische Rettung der Modernität, en “Adorno-Konferenz 1983”, Frankfurt, Suhrkamp. 
WIGGERSHAUS, R. 1997. Die Frankfurter Schule: Geschichte, Teoretische Entwicklung und politische Bedeutung”, ed. DTV, München.

ZENCK, M. 1977. Kunst als Begriffslose Erkenntnis, Zum Kunstbegriff der ästhetischen Theorie Theodor W. Adornos, ed. Fink, München.

ZIRDEN, S. 2005. Theorie des Neuen, Konstruktion einer ungeschriebenen Theorie Adornos, ed. Königshausen \& Neumann, Würzburg. 